Prepared in cooperation with the Santa Ana Watershed Project Authority

Application of a Watershed Model (HSPF) for Evaluating Sources and Transport of Pathogen Indicators in the Chino Basin Drainage Area, San Bernardino County, California

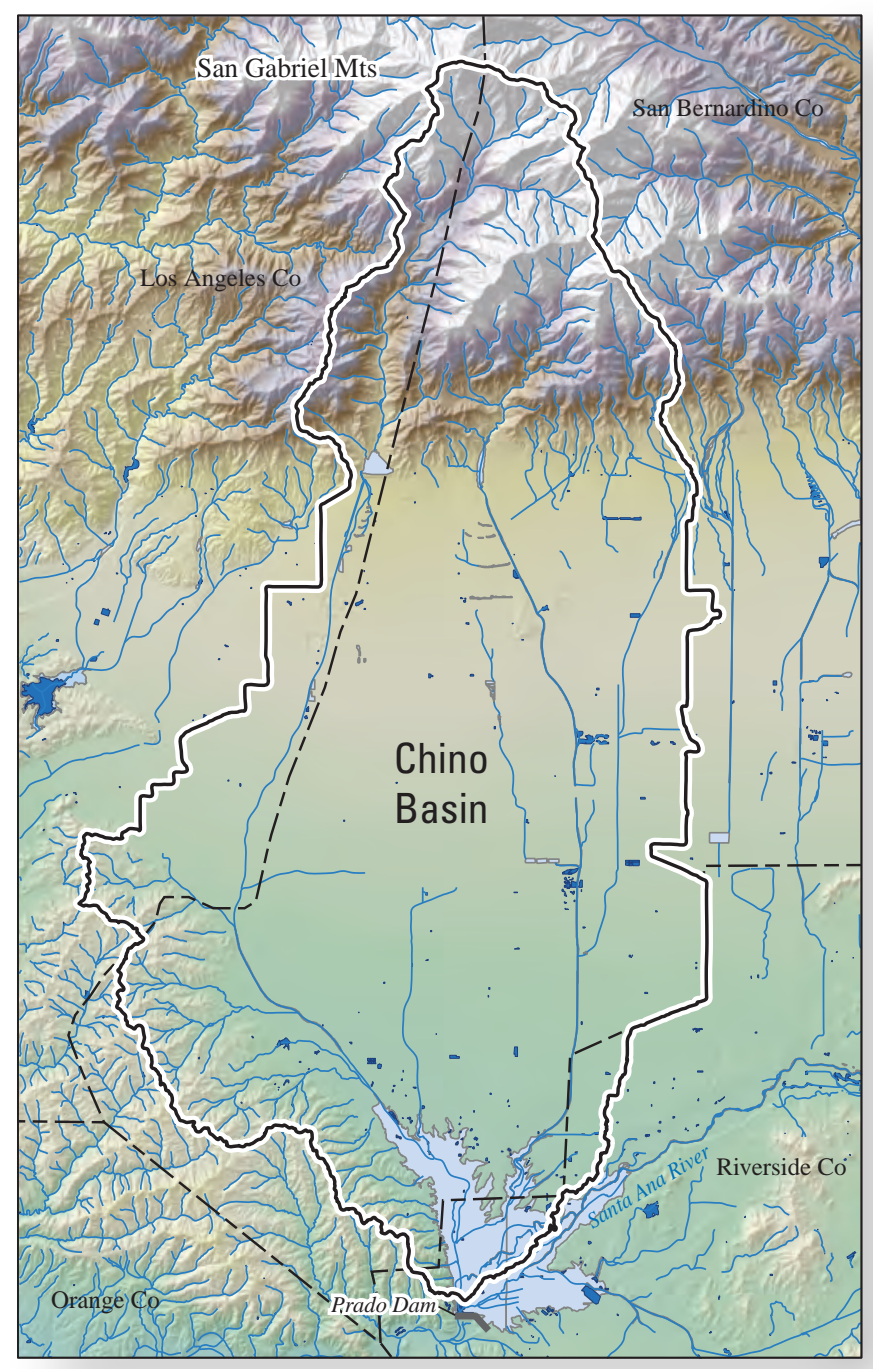

Scientific Investigations Report 2009-5219 



\section{Application of a Watershed Model (HSPF) for Evaluating Sources and Transport of Pathogen Indicators in the Chino Basin Drainage Area, San Bernardino County, California}

By Joseph A. Hevesi, Lorraine E. Flint, Clinton D. Church, and Gregory 0. Mendez

In cooperation with Santa Ana Watershed Project Authority

Scientific Investigations Report 2009-5219 


\section{U.S. Department of the Interior \\ KEN SALAZAR, Secretary \\ U.S. Geological Survey \\ Marcia K. McNutt, Director}

U.S. Geological Survey, Reston, Virginia: 2011

For more information on the USGS - the Federal source for science about the Earth, its natural and living resources, natural hazards, and the environment, visit $h t t p: / / w w w . u s g s . g o v$ or call 1-888-ASK-USGS

For an overview of USGS information products, including maps, imagery, and publications, visit http://www.usgs.gov/pubprod

To order this and other USGS information products, visit http://store.usgs.gov

Any use of trade, product, or firm names is for descriptive purposes only and does not imply endorsement by the U.S. Government.

Although this report is in the public domain, permission must be secured from the individual copyright owners to reproduce any copyrighted materials contained within this report.

Suggested citation:

Hevesi, J.A., Flint, L.E., Church, C.D., and Mendez, G.O., 2011, Using a watershed model (HSPF) to evaluate sources and transport of pathogen indicator bacteria in the Chino Basin, San Bernardino County, California: U.S. Geological Survey Scientific Investigations Report 2009-5219, 148 p. 


\section{Contents}

Abstract Introduction
Background
Purpose and Scope
Characteristics of the Chino Basin
Topography and Geology
$\quad$ Surfate
Land Cover and Use
Water Quality


Model Application: Evaluation of Contribution to Bacteria Contamination on the Basis of Flow Process and Land Use .......................................................................................66

1988-2005 Simulation Results: Summary of Base Case ......................................................66

Flow-Process Contributions to Bacteria Contamination......................................................72

Contribution of Flow Processes for Selected Storms ...................................................73

Concentration Duration Analysis for Flow-Process Contributions .................................75

Flow Processes Contributions to Average Bacteria Concentrations ...............................77

Evaluation of Source Area Contribution on the Basis of Land Use ........................................80

Land-Use Contributions to Bacteria Concentrations for Selected Storms.....................81

Model Application: Analysis of Basin Response to Possible Climate and Land-Use Changes......94

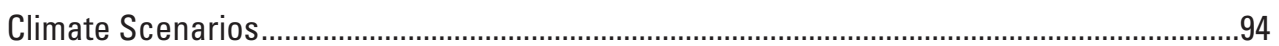

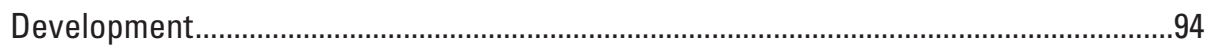

Results of Air Temperature Scenarios .......................................................................94

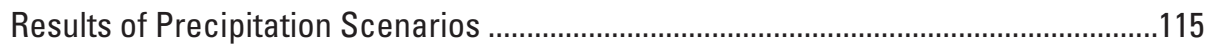

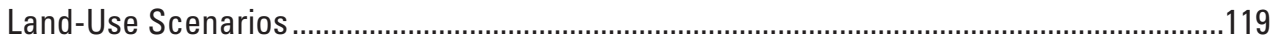

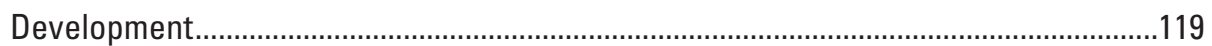

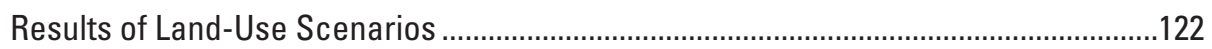

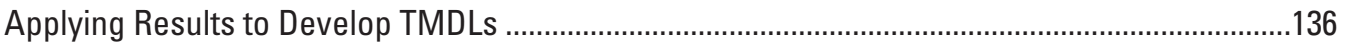

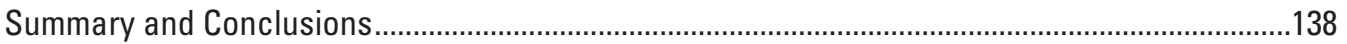

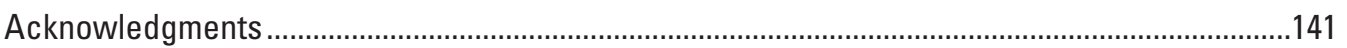

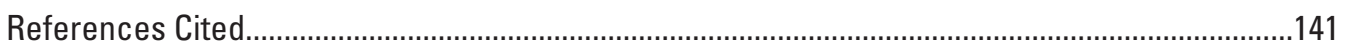

Appendix 1. Water-Quality Data Collected by the USGS in Water-Year 2004 in the Chino Basin. 


\section{Figures}

1. Regional map of study area and other basins used to study indicator bacteria in

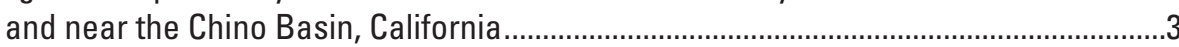

2. Location of study area, model boundary, water bodies, and drains in the Chino Basin, California. 3

Maps of geology and soil units used to develop the HSPF model for the Chino Basin, California

4. Average monthly precipitation from PRISM for November and January for the Chino Basin, California ...

5. Map of land-use and vegetation categories for the Chino Basin, California 10

6. Measured hourly stream discharge at gage 11073495 and measured bacteria concentrations at sample site MC for the 11/12/2003-11/13/2003 storm, the 2/2/2004-2/3/2004 storm, and the 2/22/2004-2/23/2004 storm in the Chino Basin, California

7. Measured fecal coliform data and measured E. coli, enterococci, and total coliforms for all storm sampling events in the Chino Basin, California.

8. Streamflow hydrographs of and measured fecal coliform bacteria concentrations for water-years 1996-2005 in daily streamflow at gage 11073495 and daily fecal coliform concentrations at site MC, and monthly streamflow at gage 11073360 and daily fecal coliform concentrations at sample site CHIS in the Chino Basin, California

9. Routing processes represented by the Hydrological Simulation Program-FORTRAN code for the simulation of fecal coliform bacteria transport and storage parameters

10. Base model segmented by average precipitation in January, and delineated hydrologic response units for each reach in the Chino Basin, California

11. Submodels of basin area upstream of each calibration gage used for hydrologic calibration of the Chino Basin model

12. Subbasins used in applications of calibrated model in the Chino Basin .........................30

13. Map showing percentage of imperviousness of the Chino Basin, California ..................33

14. Simulated and measured hourly streamflow for February 2004 for the calibration period for Chino Creek gage 11073360 and San Antonio Creek gage 11073300 in the Chino Basin, California

15. Flow duration curves for simulated and measured streamflow for calibration and verification periods for Chino Creek, Mill Creek, San Antonio Creek, West Branch Cucamonga Creek, and San Antonio Canyon reach in the Chino Basin, California

16. Simulated and measured storm-flow bacteria concentrations for storm of $11 / 12 / 2003-11 / 13 / 2003$ at site MC, and for storms of 2/2/2004 and 2/22/2004 at sample site INDND, sample site INDD, sample site RECND, sample site RECGC, sample site RECD, sample site RESD, sample site $S C$, sample site $D$, and sample site $\mathrm{MC}$ reach in the Chino Basin, California

17. Simulated and measured average bacteria concentrations in the Chino Basin, California, for the water-year 2004 storm and land-use targeted sampling sites used for model calibration 
18. Simulated streamflow and simulated and measured bacteria concentrations at sample site D, 1996-1998, sample site MC, 2002-2004, sample site CCM2, 2002-2004, sample site CHIS, 2002-2005, sample site IHC, 2002-2005, sample site BVAM, 2002-2004, and sample site PPOC, 2002-2004 in the Chino Basin, California

19. Simulated and measured average bacteria concentrations in the Chino Basin for all sampling sites used for model calibration and verification ......

20. Simulated hourly bacteria concentrations affected by different flow processes during storms in February 2004 at sample site $D$ in the Chino Basin, California...........73

21. Simulated daily bacteria concentrations affected by different flow processes for storms during December-March, water-year 2004, at Mill Creek outflow, and storms during December-March, water-year 2005, at Mill Creek outflow in the Chino Basin, California

22. Concentration durations for simulated hourly bacteria concentrations affected by different flow processes at San Antonio Dam outflow, sample site D, sample site PPOC (Prado Park Lake outflow), Chino Creek outflow, sample site CCM1, sample site CCM2, and Mill Creek outflow for water-years 1988-2005 in the Chino Basin, California

23. Land-use contributions to simulated bacteria concentrations at Chino Creek outflow for storms in February 2004, Mill Creek outflow for storms in February 2004, Chino Creek outflow for storms in February 2005, and Mill Creek outflow for storms in February 2005 in the Chino Basin, California

24. Concentration durations for simulated hourly bacteria concentrations affected by different land uses at San Antonio Dam outflow, sample site D, sample site PPOC, Chino Creek outflow, sample site CCM1, sample site CCM2, and Mill Creek outflow for water-years 1988-2005 in the Chino Basin, California

25. Simulated air temperature scenarios for water-years 1988-2005 at upper San Antonio Canyon in the Chino Basin: monthly snow pack, monthly streamflow, and monthly bacteria concentration

26. Simulated air-temperature scenarios at San Antonio Dam outflow in the Chino Basin during water-years 1988-2005: flow duration for hourly streamflow and concentration duration for hourly bacteria concentrations

27. Flow duration of simulated hourly streamflow for precipitation scenarios for water-years 1988-2005 at San Antonio Dam outflow, Prado Park Lake outflow (sample site PPOC), and Chino Creek outflow in the Chino Basin, California ...

28. Concentration duration of simulated hourly bacteria concentration for precipitation scenarios for water-years 1988-2005 at San Antonio Dam outflow, Prado Park Lake outflow (sample site PPOC), and Chino Creek outflow in the Chino Basin, California

29. Simulated daily bacteria concentrations sampled during storms in water-year 2005 for 6 land-use scenarios at Prado Park Lake outflow, Chino Creek outflow, and Mill Creek outflow in the Chino Basin, California

30. Concentration duration for simulated hourly bacteria concentrations for 6 land-use scenarios during water-year 1988-2005 at Prado Park Lake outflow, Chino Creek outflow, and Mill Creek outflow in the Chino Basin, California.... 


\section{Tables}

1. Storm sampling locations and results for fecal coliforms in samples collected November 2003 and February 2004 in the Chino Basin, California.

2. Variability in fecal coliform densities from replicate samples collected on February 22-23, 2004, at various sites in the Chino Basin, California...

3. Supplemental water quality data and primary land uses input for model calibration, from water samples collected during 1993-2004 in the Chino Basin, California

4. Hydrological Simulation Program-FORTRAN (HSPF) model calibration parameters for hydrologic and transport simulations of fecal coliforms used in several regional models and the Chino Basin model, as well as default HSPF parameters.

5. Average values for precipitation and air temperature for 46 model segments used for the Chino Basin model, 1970-2005.

6. Meteorological and streamflow data sources, number of stations or station identification, and years with available data used for the Chino Basin model

7. Average State Soil Geographic Database (STATSG0) soil properties for the Chino Basin model.

8. Initial and adjusted pervious and impervious areas for each land use defined in the Chino Basin model

9. Land-use acreages for impervious and pervious land unit types for upstream subbasin areas contributing to sampling locations in the Chino Basin, California .......35

10. Measured and simulated streamflow values for highest and lowest flows and regression results for U.S. Geological Survey and San Antonio Dam sites in the Chino Basin, California

11. Values for transport parameters S00, ACCUM, SOOLIM, and WSOOP for 12 land uses and impervious and pervious land units in the Chino Basin, California

12. Calibration summary of simulated fecal coliform concentrations and measured indicator bacteria concentrations for 18 sampling sites in the Chino Basin, California

13A. Summary of 1988-2005 simulation results and percent contribution to bacteria loading by flow process and land use for locations for the Chino Creek and San Antonio Canyon subbasins in the Chino Basin, California

13B. Summary of 1988-2005 simulation results and percent contribution to bacteria loading by flow process and land use for locations in the Mill Creek submodel in the Chino Basin, California

14A. Summary of 1988-2005 simulation results for air temperature scenarios at sample site IHC and San Antonio Dam outflow in the Chino Creek subbasin, California

14B. Summary of 1988-2005 simulation results for air temperature scenarios at sample site CCM1 and Mill Creek outflow in the Mill Creek subbasin, California...

15A. Summary of 1988-2005 simulation results for precipitation scenarios at San Antonio Dam outflow in the Chino Basin, California

15B. Summary of 1988-2005 simulation results for precipitation scenarios at storm sample site $\mathrm{D}$ in the Chino Basin, California 
15C. Summary of 1988-2005 simulation results for precipitation scenarios at Prado Lake outflow in the Chino Basin, California

15D. Summary of 1988-2005 simulation results for precipitation scenarios at Chino Creek outflow in the Chino Basin, California 103

15E. Summary of 1988-2005 simulation results for precipitation scenarios at sample site CCM1 in the Chino Basin, California .... 105

15F. Summary of 1988-2005 simulation results for precipitation scenarios at sample site CCM2 in the Chino Basin, California

15G. Summary of 1988-2005 simulation results for precipitation scenarios at Mill Creek outflow in the Chino Basin, California

16A. Summary of 1988-2005 simulation results for six land use scenarios for sample site $D$ in the Chino Basin, California

16B. Summary of 1988-2005 simulation results for six land use scenarios at Prado Park Lake outflow in the Chino Basin, California

16C. Summary of 1988-2005 simulation results for six land use scenarios at Chino Creek outflow in the Chino Basin, California

16D. Summary of 1988-2005 simulation results for six land use scenarios at Mill Creek outflow in the Chino Basin, California.

Appendix 1. Water quality data for bacteriological samples collected by U.S. Geological Survey during storms in 2003 and 2004 in the Chino Basin, California 


\section{CONVERSION FACTORS, DATUM, AND ABBREVIATED WATER-QUALITY UNITS}

\begin{tabular}{|c|c|c|}
\hline Multiply & By & To obtain \\
\hline \multicolumn{3}{|c|}{ Length } \\
\hline inch (in.) & 2.54 & centimeter $(\mathrm{cm})$ \\
\hline foot (ft) & 0.3048 & meter (m) \\
\hline mile (mi) & 1.609 & kilometer (km) \\
\hline \multicolumn{3}{|c|}{ Area } \\
\hline acre & 4,047 & square meter $\left(\mathrm{m}^{2}\right)$ \\
\hline acre & 0.4047 & hectare \\
\hline square mile $\left(\mathrm{mi}^{2}\right)$ & 259.0 & hectare \\
\hline \multicolumn{3}{|c|}{ Volume } \\
\hline gallon (gal) & 3.785 & liter $(\mathrm{L})$ \\
\hline gallon (gal) & 0.003785 & cubic meter $\left(\mathrm{m}^{3}\right)$ \\
\hline million gallons (Mgal) & 3,785 & cubic meter $\left(\mathrm{m}^{3}\right)$ \\
\hline cubic foot $\left(\mathrm{ft}^{3}\right)$ & 0.028317 & cubic meter $\left(\mathrm{m}^{3}\right)$ \\
\hline acre-foot (acre-ft) & 1,233 & cubic meter $\left(\mathrm{m}^{3}\right)$ \\
\hline \multicolumn{3}{|c|}{ Flow } \\
\hline cubic foot per second $\left(\mathrm{ft}^{3} / \mathrm{s}\right)$ & 0.02832 & cubic meter per second $\left(\mathrm{m}^{3} / \mathrm{s}\right)$ \\
\hline million gallons per day (Mgal/d) & 0.04381 & cubic meter per second $\left(\mathrm{m}^{3} / \mathrm{s}\right)$ \\
\hline inch per hour (in./hr) & 0.0254 & meter per hour (m/hr) \\
\hline inch per year (in./yr) & 2.54 & centimeter per year (cm/yr) \\
\hline \multicolumn{3}{|c|}{ Mass } \\
\hline ounce, avoirdupois (oz) & 28.35 & gram (g) \\
\hline pound, avoirdupois (lb) & 0.4536 & kilogram (kg) \\
\hline pound per acre (lb/acre) & 1.121 & kilogram per hectare (kg/ha) \\
\hline
\end{tabular}

Temperature is reported in degrees Celsius $\left({ }^{\circ} \mathrm{C}\right)$ which can be converted to degrees Fahrenheit $\left({ }^{\circ} \mathrm{F}\right)$ as follows:

$$
{ }^{\circ} \mathrm{F}=1.8\left({ }^{\circ} \mathrm{C}\right)+32^{\circ}
$$

Temperature in degrees Fahrenheit $\left({ }^{\circ} \mathrm{F}\right)$ may be converted to degrees Celsius $\left({ }^{\circ} \mathrm{C}\right)$ as follows:

$$
{ }^{\circ} \mathrm{C}=\left({ }^{\circ} \mathrm{F}-32\right) / 1.8
$$

Horizontal coordinate information is referenced to the North American Datum of 1927 (NAD27).

Abbreviated water-quality units: Bacteria concentrations are reported in units of colony forming units per 100 milliliters (cfu/100 mL). 


\section{Acronyms and Abbreviations}

$\begin{array}{ll}\text { ACCUM } & \text { parameter defining non-point source daily land-surface loading rate for bacteria } \\ \text { ADAPS } & \text { USGS automated data processing system for streamflow data } \\ \text { AFO } & \text { animal feeding operations } \\ \text { AOQUAL } & \text { algorithm representing transport processes with baseflow } \\ \text { CIMIS } & \text { California Irrigation Management information System } \\ \text { cfu } & \text { colony forming units } \\ \text { DEM } & \text { digital elevation model } \\ \text { DEO } & \text { Department of Environmental Quality } \\ \text { FSTDEC } & \text { first-order exponential decay coefficient in channels } \\ \text { FTABLE } & \text { function table in HSPF describing the relation between discharge and stage } \\ \text { GIS } & \text { geographic information system }\end{array}$

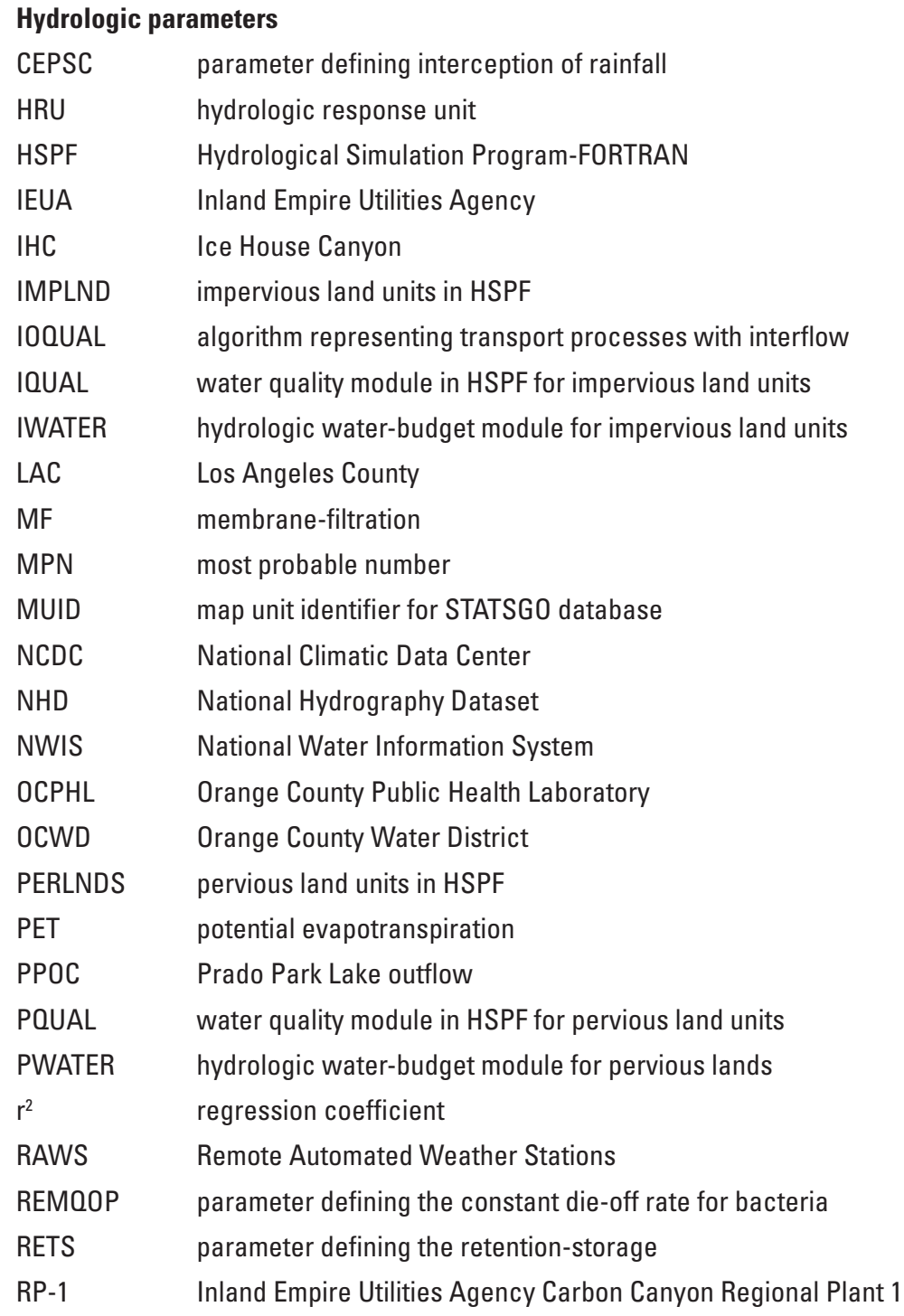


RWOCB Regional Water Quality Control Board

SAWPA Santa Ana Watershed Project Authority

SBC San Bernardino County

SCCWRP Southern California Coastal Water Research Project Authority

SOQUAL algorithm representing surface flow processes

SHADE parameter defining shading on snow

SQ0 initial loading on land surfaces

SOOLIM parameter defining the storage limit of loading by estimating the die-off on the land surface between runoff events

STATSGO State Soil Geographic Database

SSURGO Soil Survey Geographic Database

TDS total dissolved solids

TMDL Total Maximum Daily Load (a pollution control plan)

USACE U.S. Army Corps of Engineers

USEPA U.S. Environmental Protection Agency

USGS U.S. Geological Survey

WRCC Western Regional Climate Center

WSOOP parameter defining the rainfall needed to remove 90 percent of accumulated pollutant on land

WY

water year, October 1 through September 31 
This page intentionally left blank. 


\title{
Application of a Watershed Model (HSPF) for Evaluating Sources and Transport of Pathogen Indicators in the Chino Basin Drainage Area, San Bernardino County, California
}

\author{
By Joseph A. Hevesi, Lorraine E. Flint, Clinton D. Church, and Gregory O. Mendez
}

\section{Abstract}

A watershed model using Hydrologic Simulation Program-FORTRAN (HSPF) was developed for the urbanized Chino Basin in southern California to simulate the transport of pathogen indicator bacteria, evaluate the flow-component and land-use contributions to bacteria contamination and water-quality degradation throughout the basin, and develop a better understanding of the potential effects of climate and land-use change on water quality. The calibration of the model for indicator bacteria was supported by historical data collected before this study and by samples collected by the U.S. Geological Survey from targeted land-use areas during storms in water-year 2004. The model was successfully calibrated for streamflow at 5 gage locations representing the Chino Creek and Mill Creek drainages. Although representing pathogens as dissolved constituents limits the model's ability to simulate the transport of pathogen indicator bacteria, the bacteria concentrations measured over the period 1998-2004 were well represented by the simulated concentrations for most locations. Hourly concentrations were more difficult to predict because of high variability in measured bacteria concentrations. In general, model simulations indicated that the residential and commercial land uses were the dominant sources for most of the pathogen indicator bacteria during low streamflows. However, simulations indicated that land used for intensive livestock (dairies and feedlots) and mixed agriculture contributed the most bacteria during storms.

The calibrated model was used to evaluate how various land use, air temperature, and precipitation scenarios would affect flow and transport of bacteria. Results indicated that snow pack formation and melt were sensitive to changes in air temperature in the northern, mountainous part of the Chino Basin, causing the timing and magnitude of streamflow to shift in the natural drainages and impact the urbanized areas of the central Chino Basin. The relation between bacteria concentrations and air temperature was more complicated, and did not substantially affect the quality of water discharging from the Chino Basin into the Santa Ana River. Changes in precipitation had a greater basin-wide affect on bacteria concentrations than changes in air temperature, and varied according to location. Drainages representing natural conditions had a decrease in bacteria concentrations in correlation with an increase in precipitation, whereas drainages in the central and southern part of the Chino Basin had an increase in bacteria concentrations. Drier climate conditions tended to result in higher sensitivity of simulated bacteria concentrations to changes in precipitation. Simulated bacteria concentrations in wetter climates were usually less sensitive to changes in precipitation because bacteria transport becomes more dependent on the land-use specified bacteria loading rates and the storage limits. Bacteria contamination from impervious-area runoff is affected to a greater degree by drier climates, whereas contamination from pervious-area runoff is affected to a greater degree by wetter climates. Model results indicated that the relation between precipitation, runoff, and bacteria contamination is complicated because after the initial bacteria washoff and transport from the land surfaces during the beginning of a storm period, subsequent runoff has fewer bacteria available for washoff, which then dilutes the concentrations of bacteria in the downstream reach. It was illustrated that pathogen indicator bacteria transport depends most significantly on the relation of imperviousness to runoff, which controls the frequency, and often the magnitude, of transport, and on the contribution of higher bacteria loading rates used for pervious land areas, especially intensive feedlots, to the infrequent, but very high, peaks of bacteria contamination. 
The indicator bacteria transport model for the Chino Basin was based on the assumption that non-point bacteria loading rates can be defined according to 12 different land use categories. Results from water-quality sampling, model calibration, and model application indicated that important differences exist for loading rates and parameters controlling bacteria washoff between natural land use, urban land use, and agricultural land use. In addition, the fraction of impervious area for a given land use is a critical factor in determining the effect of storm runoff on downstream water quality. Increasing the impervious area usually increases the frequency of impaired water quality caused by bacteria that are washed off during smaller storms. An increase in the fraction of pervious area having higher non-point bacteria loading rates and washoff limits does not necessarily cause the frequency of impaired water quality to increase, and may even cause the frequency of impaired water quality to decrease, but the maximum for bacteria concentrations during the largest storms will likely be much higher. Additional sampling during large storms would likely provide a better assessment of non-point-source loading rates and washoff limits for pervious areas with agricultural and recreational land use that are likely sources of bacteria contamination.

\section{Introduction}

\section{Background}

The Santa Ana River, the largest stream system in southern California, is the primary water supply for approximately 2 million people (fig. 1). The Santa Ana Regional Water Quality Control Board (RWQCB) has listed the Santa Ana River and its tributaries in the Chino Basin as impaired water bodies on the RWQCB 303(d) list from the Clean Water Act. The main constituent of regulatory concern is pathogens that have impaired the waters for the beneficial uses of warm freshwater habitat and non-contact water recreation. Baseflow in the Chino Basin streams consist primarily of secondary treated wastewater. Periodic storm events during the rainy season (December through March) supply water to the streams that consist primarily of urban runoff. In addition to urban runoff, there is considerable runoff from the concentrated dairy operations in the southern part of the Chino Basin. Wastes in runoff from animal feeding operations (AFO) in the Chino Basin may adversely affect water quality in Chino Creek, Mill Creek, and the Santa Ana River (fig. 2). As of 1995 the Chino Basin had one of the highest concentrations of dairy animals in the world, with 279 facilities and more than 250,000 cows (Rice, 2005) within an area less than 50 square miles (30,000 acres). Applying manure to the ground in the Chino Basin (fig. 1) has resulted in significant ground-water pollution, specifically total dissolved solids (TDS) and nitrate (shipping solid wastes out of the basin and to bio-recycling facilities has reduced pollution). Contamination of ground water in the Chino Basin affects the quality of water in the Santa Ana River where ground water from the Chino Basin contributes to the surface flow of the Santa Ana River during the wetter winter months, especially during wetter than normal seasons.

Reaches in Chino Creek and two tributaries, Mill Creek and Prado Park Lake (in Prado Basin), together with reaches of the Santa Ana River (fig. 2), were included on the 1998 Clean Water Act Section 303(d) list of impaired water bodies for pathogens, thus triggering action for developing a pollution control plan, the Total Maximum Daily Load (TMDL) for pathogens. The TMDL process has begun for these Chino Basin water bodies, and the Santa Ana Watershed Project Authority (SAWPA) is currently assisting the Santa Ana RWQCB in collecting data from the Chino Basin to develop TMDLs.

Developing TMDLs typically requires using numerical or analytical models to evaluate the transport and storage of water and water-quality constituents (Moyer and Hyer, 2003). Calibrated models can be used to help develop a better understanding of the likely affect of climate change, land-use change, or changes in management practices on water quality. For this study, the Hydrological Simulation ProgramFORTRAN (HSPF) was used to simulate the transport of water and pathogen indicator bacteria in the Chino Basin. Pathogen indicator bacteria include fecal coliform, Escherichia coli (E. coli), and enterococci. Indicator bacteria are typically used to develop pathogen TMDLs because the presence of indicator bacteria is correlated to the presence of pathogens, which are difficult to measure directly. 


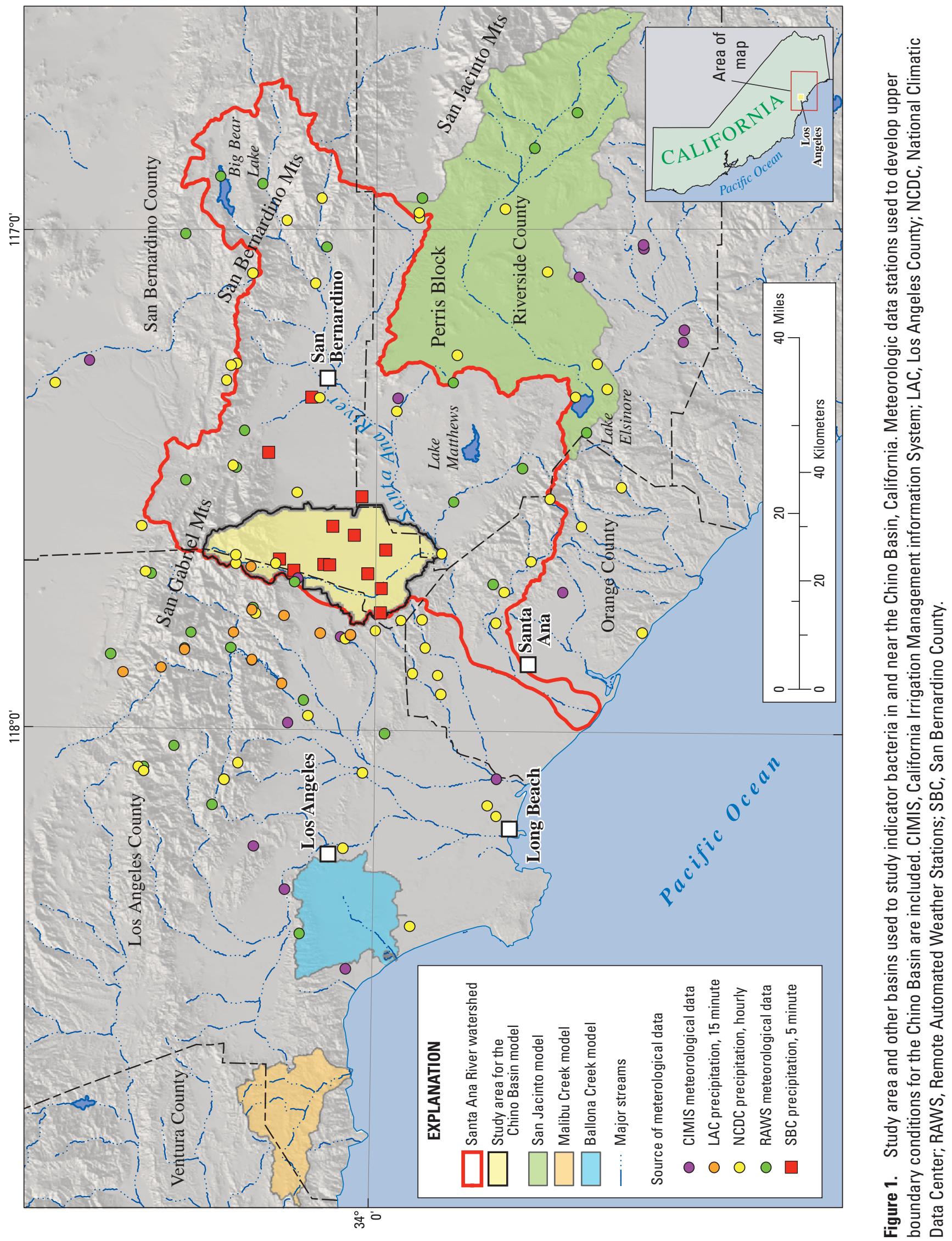




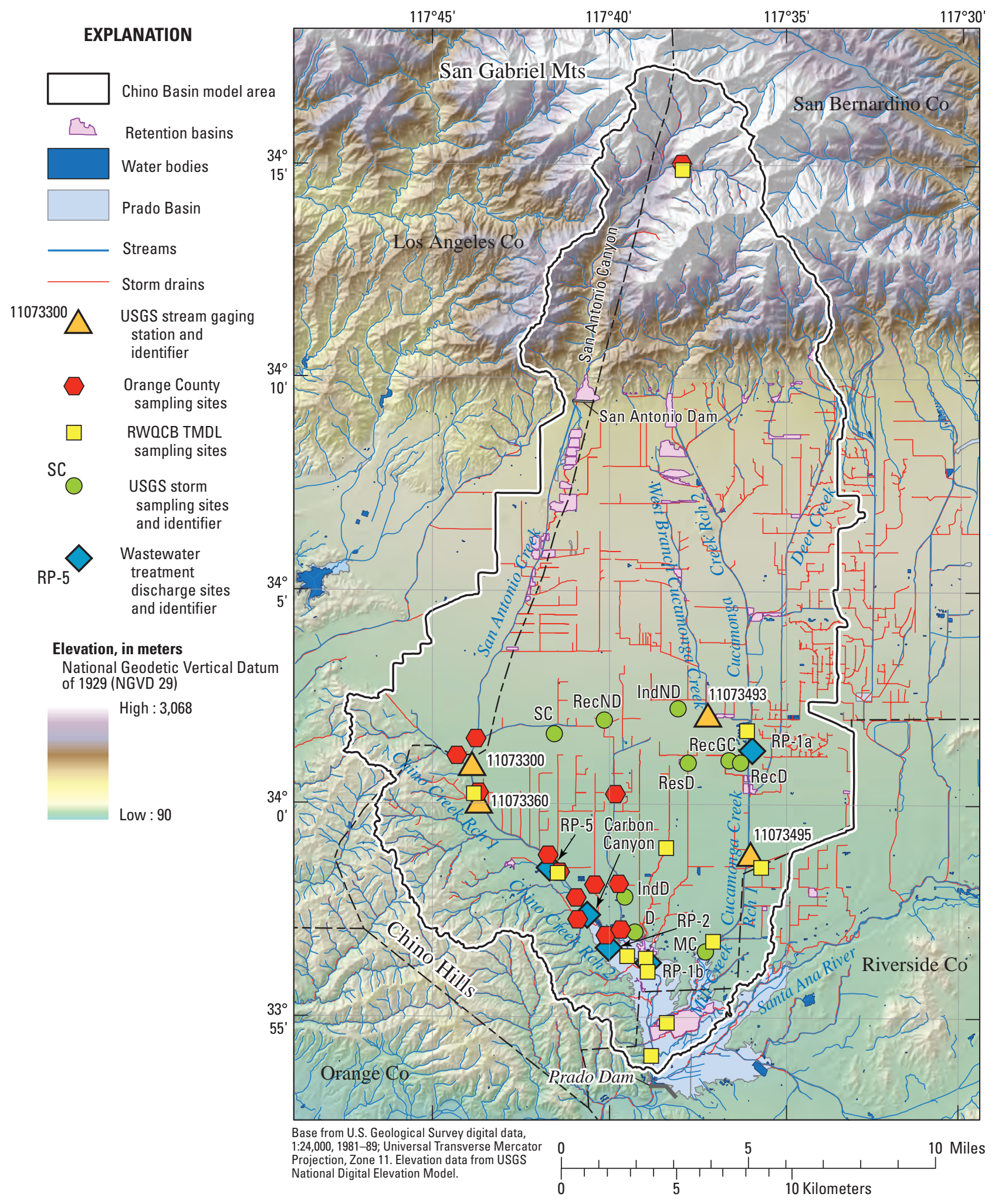

Figure 2. Study area, model boundary, water bodies, and drains in the Chino Basin, California.

RWQCB, [Santa Ana] Regional Water Quality Control Board; TMDL, Total Maximum Daily Load; USGS, U.S. Geological Survey. 


\section{Purpose and Scope}

This report describes the collection and analysis of pathogen indicator bacteria (total coliform, fecal coliform, $E$. coli, and enterococci), and the development, calibration, and application of the HSPF model to the Chino Basin. Land-use, meteorological, topographical, and water-quality and streamflow data for the Chino Basin were compiled to develop the necessary input parameters for the HSPF model. The U.S. Geological Survey (USGS) collected water-quality samples at 9 sites (fig. 2) throughout the basin during 3 storm periods in 2004. Indicator bacteria concentrations in these samples were plotted on storm hydrographs and analyzed to determine pathogen indicator bacteria concentrations in storm runoff from urbanized and agricultural areas. Sampling sites were selected primarily to represent bacteria loadings from specific land uses. The model was calibrated for streamflow simulation using streamflow data for the 1990-2001 water years and the 2004 water year from 4 USGS gaging stations and 1 U.S. Army Corps of Engineers (USACE) gage. Streamflow simulated by the model was verified using data from water-years 2002-03 and 2005. Calibration of the model for the simulation of bacteria concentrations during storm runoff was limited because of the small number of bacteria samples coincident with storm hydrographs. Supplementary data from other investigations were included in this study to improve the transport-model calibration and allow limited verification of the transport model. The transport model was applied using various climate and land-use scenarios to improve understanding of processes controlling indicator bacteria concentrations (and thus potential pathogen contamination) at locations throughout the Chino Basin. The findings from the waterquality sampling, analysis, and transport-model application will be used to support the development and implementation of the pathogen TMDL.

\section{Characteristics of the Chino Basin}

\section{Topography and Geology}

The topography in the Santa Ana River watershed ranges from steep, rugged mountains with peaks as high as $10,700 \mathrm{ft}$ above sea level, to a broad alluvial-filled valley, bordered by the San Gabriel/San Bernardino Mountains to the northeast and the elevated Perris Block/San Jacinto Mountains to the south (fig. 1). The Santa Ana River is the main tributary draining the valley. The Chino Basin study area, located in the northwestern part of this watershed, was formed as a result of tectonic activity along major fault zones (Wildermuth
Environmental, Inc., 2003). The bottom of the basin-the effective base of the freshwater aquifer-consists of relatively impermeable sedimentary and igneous bedrock formations that are exposed at the surface in the surrounding mountains and hills. Sediments eroded from the surrounding mountains have filled the Chino Basin, providing reservoirs for ground water. In the deepest portions of the basin, these sediments are greater than 1,000 ft thick. The sediments consist of geologically old and young alluvium. The thickness of the older alluvium varies from about $200 \mathrm{ft}$ near the southwestern end of the Chino Basin to over 1,100 ft in the eastern parts of the valley and averages about $500 \mathrm{ft}$ throughout the basin. The surface outcrop is commonly distinguishable by its red-brown or brick-red color and is generally more weathered than the overlying younger alluvium. The younger alluvium occupies streambeds, washes, and other areas having recent sedimentation. The thickness of the younger alluvium varies from over $100 \mathrm{ft}$ near the mountains to just a few feet in the center of the valley. The younger alluvium generally covers most of the northern half of the Chino Basin in undisturbed areas (Wildermuth Environmental, Inc., 2003).

The stratigraphy of the Chino Basin can be described by two natural divisions: (1) the pervious formations that comprise the ground-water reservoirs are termed the water-bearing sediments and (2) the less pervious formations that enclose the ground-water reservoirs are termed the consolidated bedrock. The consolidated bedrock is further differentiated as metamorphic and igneous rocks of the basement complex partially overlain by consolidated sedimentary rocks. The water-bearing sediments overlie the consolidated bedrock, with the bedrock formations coming to the surface in the surrounding hills and highlands. The general geology of the Chino Basin and the distribution of sediments and soils are shown in figures $3 A_{2} B$.

Most recharge to the ground-water reservoirs of the Chino Basin is from percolation of direct precipitation and infiltration of streamflow within tributaries exiting the surrounding mountains and hills and within the Santa Ana River. Potential sources of recharge in the Chino Basin include the following: (1) infiltration of flow (and, locally, imported water) within unlined stream channels overlying the basin, (2) infiltration of stormwater flow and municipal wastewater discharges within the channel of the Santa Ana River, (3) underflow from the saturated sediments and fractures within the bounding mountains and hills, (4) artificial recharge at spreading grounds of storm water, imported water, and recycled water, (5) underflow from seepage across the bounding faults, (6) intermittent underflow from adjacent basins, and (7) deep percolation of precipitation and returns from use (Wildermuth Environmental, Inc., 2003). 


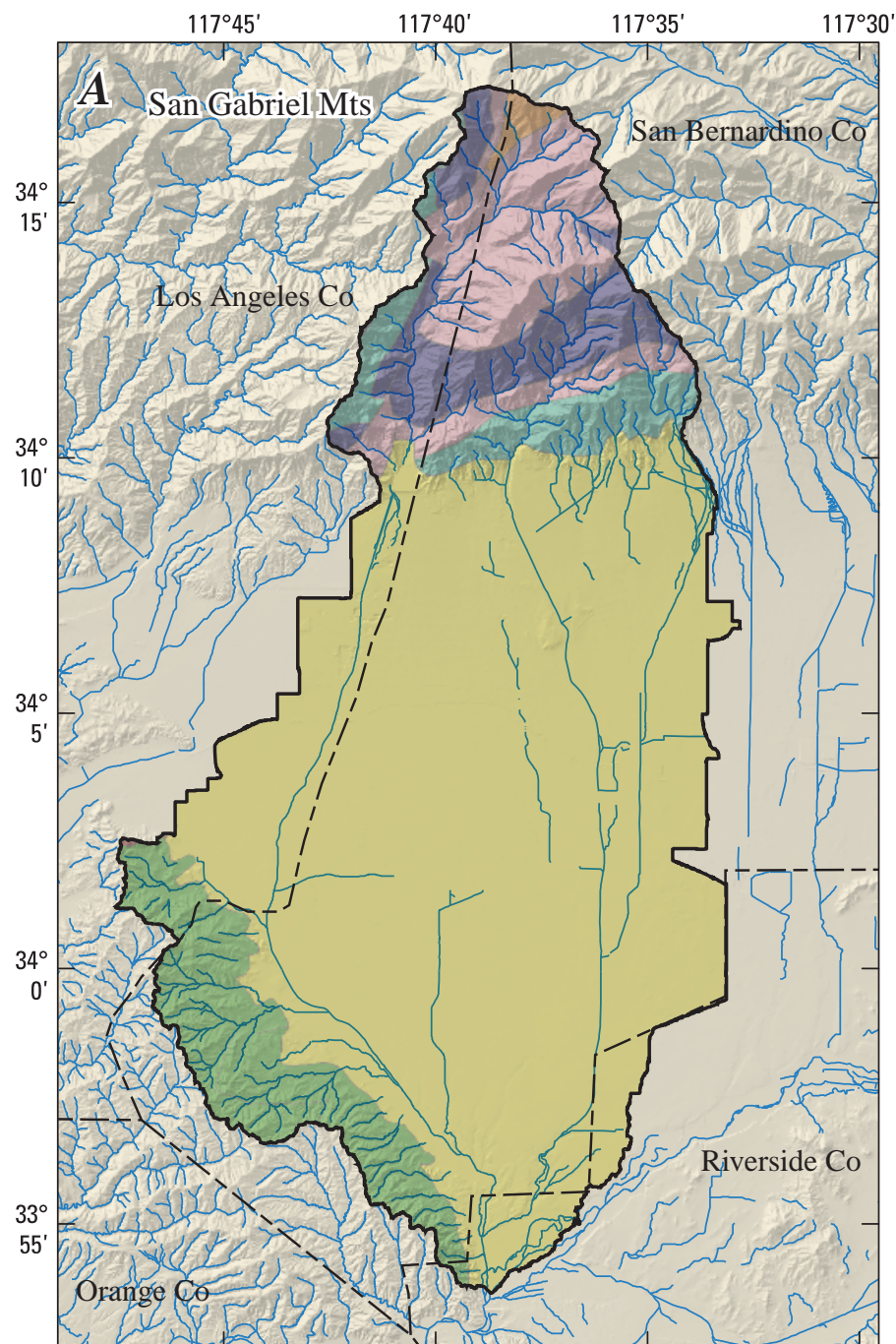

Base from U.S. Geological Survey digital data, 1:24,000, 1981-89; Universal Transverse Mercato Projection, Zone 11 . Elevation data from USGS National Digital Elevation Model.
Geology from U.S. Geological Survey digital data, 2000

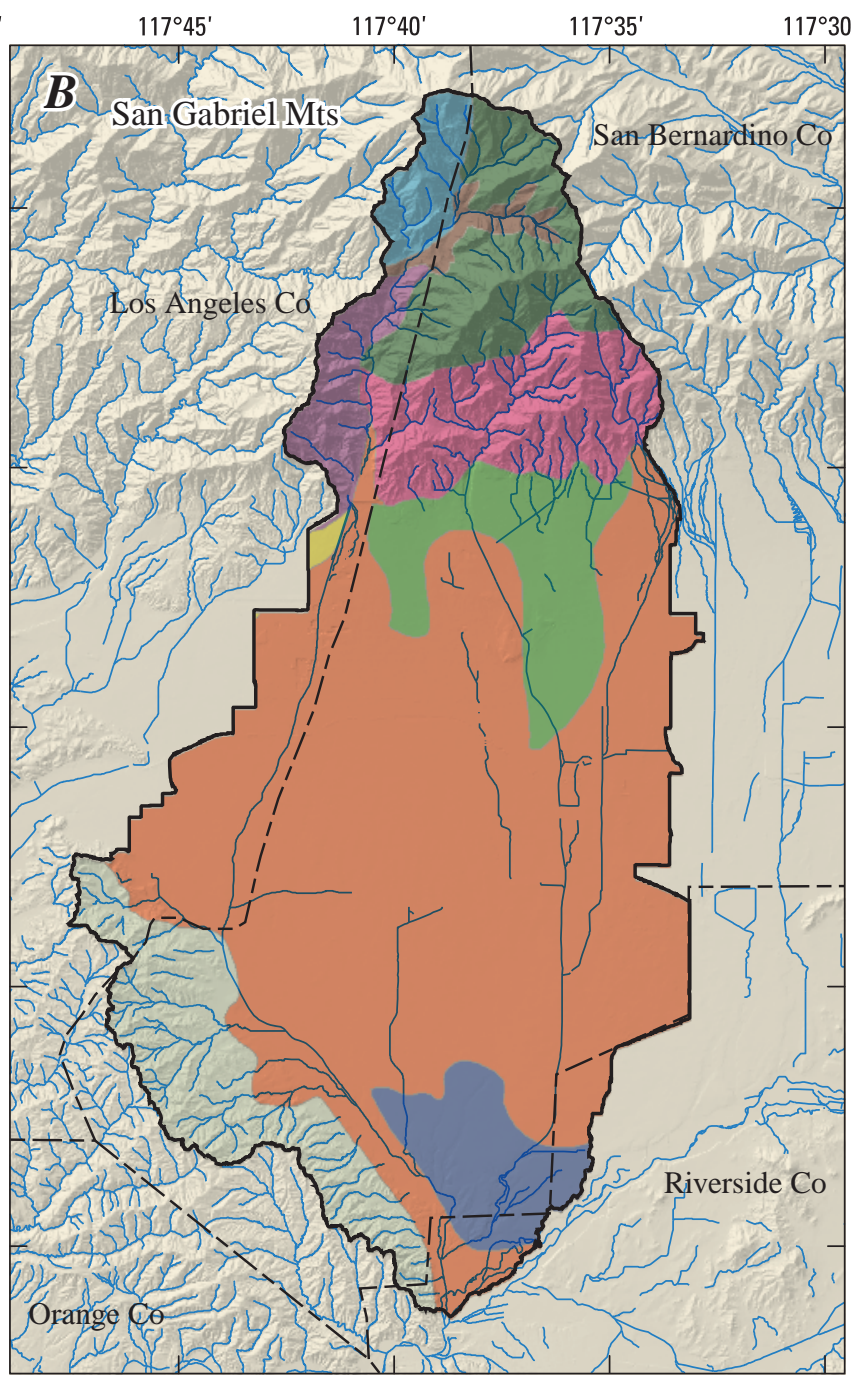

Soils from U.S. Geological Survey

\section{EXPLANATION}

Chino Basin model area $\approx$ Streams

\section{GEOLOGIC FORMATION/AGE}

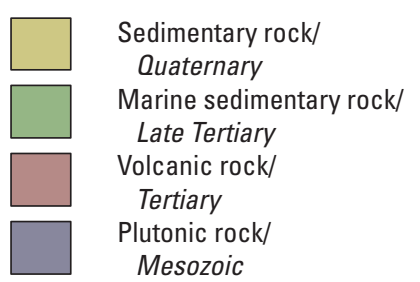

$$
\text { digital data, } 2000 \text {. }
$$

\section{STATSGO SOIL MUIDs}

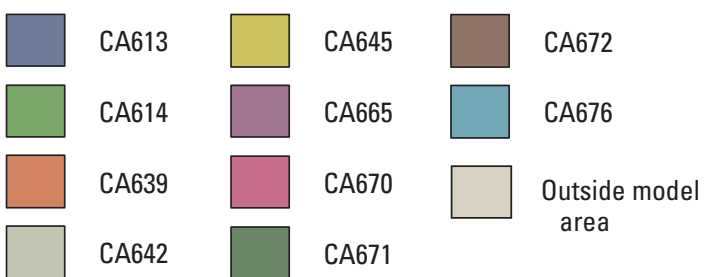

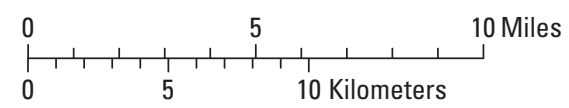

Figure 3. A. Geology and $B$. soil units used to develop the HSPF model for the Chino Basin, California. STATSG0, State Soil Geographic Database; MUID, Map Unit IDentifier. 


\section{Climate}

Warm, dry summers and cool, moist winters characterize the climate of the study area. Average annual precipitation ranges from about 18 in. in the lower part of the Chino Basin to about 40 in. in the San Gabriel Mountains. Most precipitation occurs during the winter rainy season between November and March. Average precipitation for January ranges from about 3 in. in the southern valley (fig. 4A) to more than 10 in the mountains, whereas average precipitation for July is less than 0.1 in. across the whole basin (Daly and others, 2004). The spatial distribution of average monthly precipitation is similar for most months and is characterized by the orographic effect of the San Gabriel Mountains. For example, although average November precipitation has a spatial distribution that is similar to the January pattern, the average January precipitation is over $30 \%$ greater than that for all other months (fig. $4 A, B$ ). Air temperatures across the basin in the winter are cool, with average daily temperatures in degrees Fahrenheit in January ranging from the 30s in the north, resulting in persistent mountain snowpack at the higher altitudes, to as high as 60 in the southern valley. Average daily air temperatures for July can be quite warm, ranging from 65 to 80 degrees.

\section{Surface Water and Drainage Network}

Chino Creek is a tributary of the Santa Ana River. It extends upstream to the northwest from its confluence with the Santa Ana River (fig. 2). Chino Creek is divided into two reaches. Reach 1 extends from the confluence with the Santa Ana River and flows from north to south. Except for a short segment in the upper part of the reach, Reach 1 has a semi-natural, unlined channel bed and banks that have been straightened by engineering. Chino Creek Reach 1 was added to the 303(d) pathogen-impaired-water list in 1994. Chino Creek Reach 2 extends north of its confluence with San Antonio Creek, a major tributary draining the northwestern part of the Chino Basin. Chino Creek Reach 2 flows from northwest to southeast and is concrete-lined along its channel bed and banks throughout its length. San Antonio Creek, an important drainage feature in the western Chino Basin, is a tributary to Chino Creek, Reach 2. Reach 2 was added to the 303(d) list in 1998.

Baseflow in Chino Creek consists primarily of wastewater effluent discharges from Inland Empire Utilities Agency's (IEUA) Carbon Canyon publicly owned treatment works (POTW) Regional Plant 5 (RP-5), RP-1 (from discharge into Prado Park Lake), and nuisance runoff (dry season urban runoff from excessive watering of lawns, washing cars and streets, and over-using water for other residential and commercial activities). Chino Creek received wastewater effluent discharge from RP-2 also from 1970 to 2004, but this treatment plant was discontinued (treatment operations were relocated to RP-5).
Mill Creek is a tributary to Chino Creek Reach 2 in the southeastern part of the Chino Basin (fig. 2). Most of Mill Creek is within the Prado flood control basin behind Prado Dam. Mill Creek extends from its confluence with Chino Creek to a location near the San Bernardino/Riverside County border, where its name changes to Cucamonga Creek and it is concrete-lined. Mill Creek generally flows in a northeast to southwest direction and has a natural, semi-meandering channel with an unlined channel bed and banks. Baseflow in Mill Creek consists primarily of wastewater effluent from IEUA's RP-1 and nuisance runoff. Mill Creek and Prado Basin were added to the 303(d) list in 1994.

Cucamonga Creek Reach 1 (fig. 2) flows from north to south across the central part of the Chino Basin and is concrete-lined along its channel bed and banks throughout its length. Reach 2 is upstream of Reach 1. As with Mill Creek, baseflow in Cucamonga Creek consists primarily of effluent from IEUA RP-1 and nuisance runoff. Cucamonga Creek, Reach 1, was added to the 303(d) list in 1998.

Prado Park Lake (in Prado Basin) is a 60-acre man-made lake located in the southern part of the Chino Basin at the confluence of two natural drainage channels. The lake collects runoff from both urban and agricultural areas. During low-flow conditions, urban runoff from these two channels flows under the lake through pipes, and discharges into the lake's outlet structure. The capacity of the pipes is exceeded during large storms, and the excess storm runoff is discharged directly into the lake. Water levels in Prado Park Lake are maintained by discharge of approximately 8 million gallons per day (Mgal/d) of recycled water from IEUA RP-1. Excess water flows out of the lake into Chino Creek Reach 1. Prado Park Lake was placed on the 303(d) list in 1994 as a result of a fish kill incident in 1991. Elevated nutrient and bacteria levels were identified as sources of impairment in the 303(d) listing.

With the exception of runoff from extreme storms, stormwater runoff and snow melt from the northern mountainous areas of the Chino Basin usually is diverted or lost to infiltration into ground-water storage before it reaches the major channels in the central and southern parts of the basin. San Antonio Dam is a large flood-control structure that captures most of the snow melt and storm flow from San Antonio Canyon, greatly reducing streamflow in San Antonio Creek. During extreme storms and wetter than average years, some flow is released from San Antonio Dam, but much of this flow is diverted to retention basins and spreading grounds to enhance ground-water recharge (Wildermuth Environmental, Inc., 2003). Numerous other retention basins along the base of the San Gabriel Mountains capture runoff for flood control, debris-flow control, and recharge enhancement. This greatly reduces streamflow in the major channels, such as Cucamonga and Deer Creeks. 


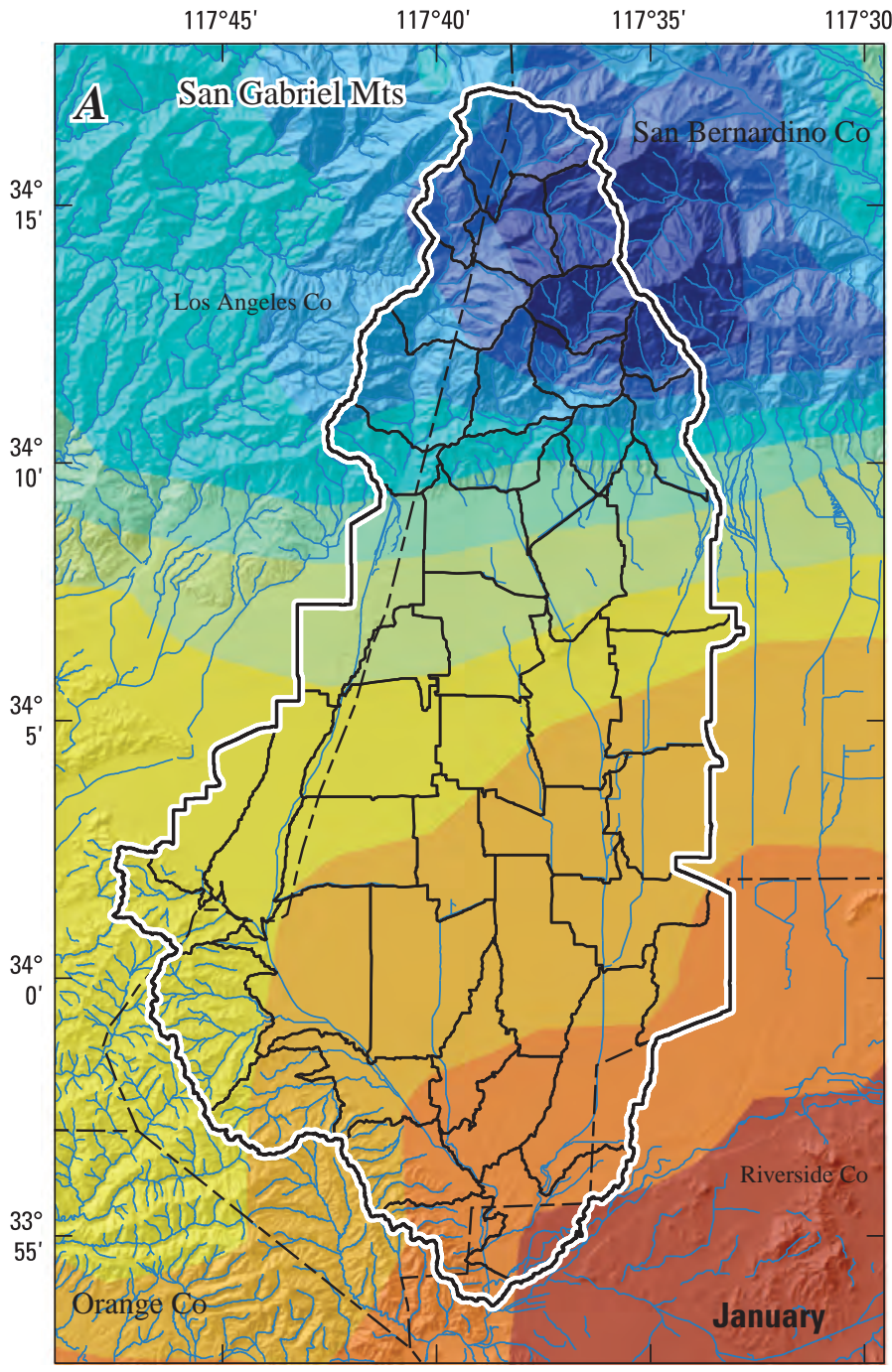

Base from U.S. Geological Survey digital data, 1:24,000, 1981-89; Universal Transverse Mercato Projection, Zone 11. Elevation data from USGS National Digital Elevation Model.

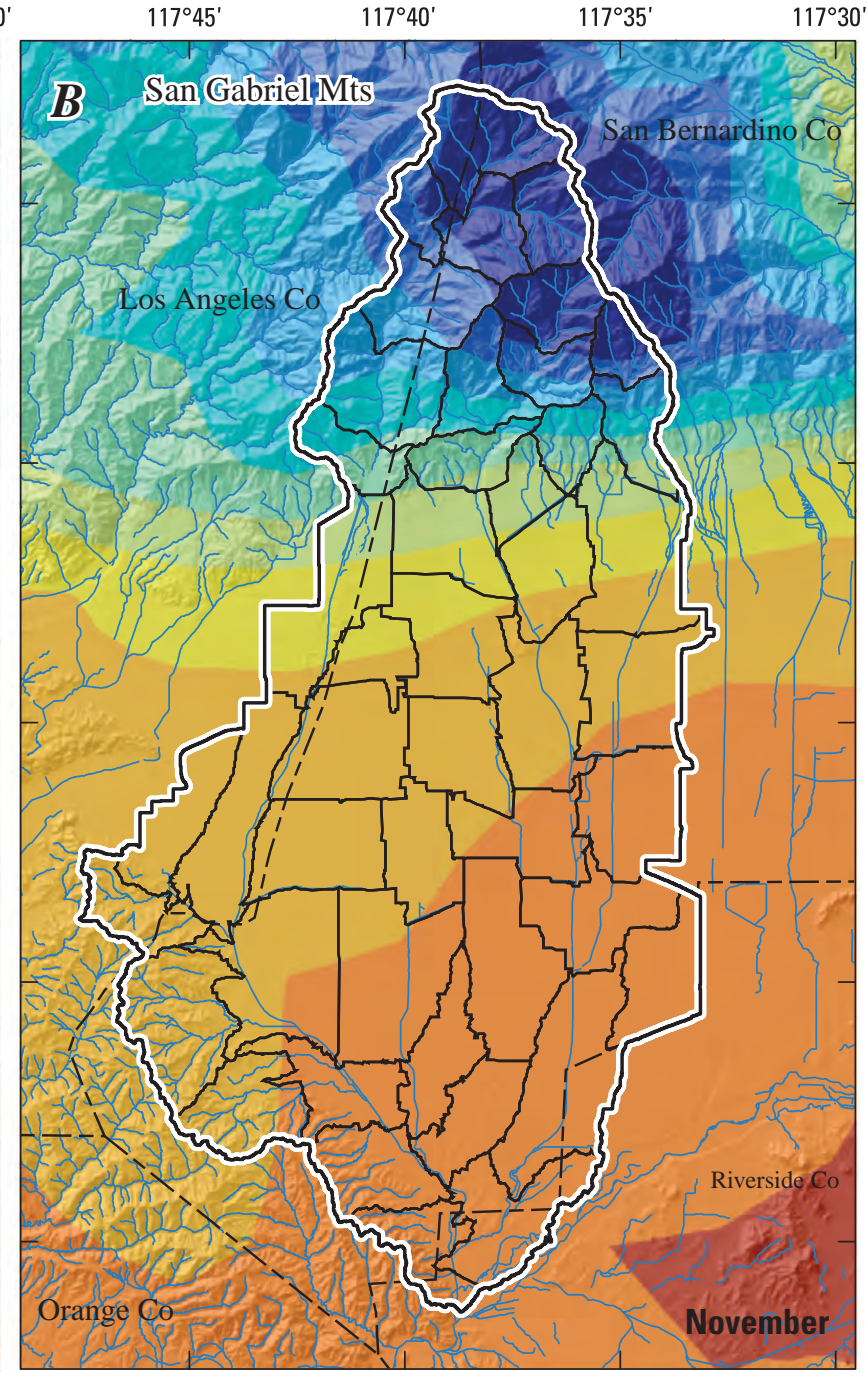

Precipitation data from U.S. Geological Survey digital data, XXXX-XX.

\section{EXPLANATION}

\section{$\square$ Chino Basin model area}

Average January precipitation, in inches

\begin{tabular}{|l|l|}
\hline 2.25 to 2.5 & 5.01 to 6 \\
\hline 2.51 to 3 & 6.01 to 7 \\
\hline 3.01 to 3.5 & 7.01 to 8 \\
\hline 3.51 to 4 & 8.01 to 9 \\
\hline 4.01 to 5 & 9.01 to 10.75 \\
\hline
\end{tabular}

Hydrologic response units $\approx$ Streams

\section{Average November precipitation, in inches}

\begin{tabular}{|l|l|}
\hline 1.25 to 2.5 & 3.51 to 4 \\
\hline 1.51 to 2 & 4.01 to 4.5 \\
\hline 2.01 to 2.5 & 4.51 to 5 \\
\hline 2.51 to 3 & 5.01 to 5.6 \\
\hline 3.01 to 3.5 & 5.51 to 6.25 \\
\hline
\end{tabular}

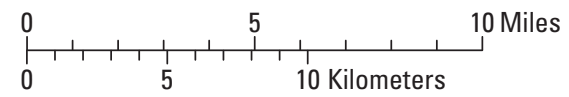

Figure 4. Average monthly precipitation from PRISM for $A$. November and $B$. January for the Chino Basin, California. 
In contrast, peak flows and total discharge volumes of storm runoff from the urbanized central and lower portions of the basin are more frequent and can be much greater than streamflow from the mountainous areas. The urbanized areas have a high percentage of impervious surfaces (roads, parking lots, rooftops), which can rapidly generate large volumes of runoff during storms. Some of this storm runoff is diverted to retention basins for flood control and recharge enhancement. However, much of the runoff during the larger storms reaches the Santa Ana River and the Prado flood control basin. Storm runoff from the central and lower parts of the Chino Basin tends to have poor water quality because of washoff of contaminants, including bacteria and associated pathogens, from urbanized and agricultural areas (including dairies).

Compared to storm runoff, wastewater discharges, and Orange County water transfers into San Antonio Creek, nuisance flow (flow originating as small inflow from urbanized areas) is only a small fraction of the total discharge from the Chino Basin into the Santa Ana River. However, data collected from previous studies (Rice, 2005) indicates that nuisance runoff may contain high densities of indicator bacteria and thus may significantly affect the overall water quality in the Chino Basin during low-flow conditions (Appendix 1).

\section{Land Cover and Use}

The central part of the Chino Basin (south of the San Gabriel Mountain front and north of USGS stream gage 11073495) is heavily urbanized with extensive areas of highdensity residential development interspersed with areas of commercial and industrial development (fig. 5). As a result of the urbanization, much of the land surface is impervious, and runoff is channelized. The urban features result in non-point sources also, as well as concentrated sources, of water-quality contaminants, including bacteria and associated pathogens. Specific sources of bacteria contamination in the urban areas of the Chino Basin are not well understood or identified, and are currently being evaluated, but general sources likely include both domesticated animals (pets) and wildlife (birds, rodents).

In contrast to the central part of the basin, most of the land area in the southern part of the Chino Basin is agricultural; about one-half of the agricultural area is used for intensive livestock operations (dairies). The dairies are likely sources of significant concentrations of pathogens. The remaining agricultural areas are also potential sources because these areas include horse ranches, poultry and hog operations, and crops using manure fertilizer.

\section{Water Quality}

Four existing point sources and 1 discontinued point source (RP2) discharge wastewater effluent into the waterways of the Chino Basin (fig. 2). Fecal coliform bacteria concentrations must be less than $200 \mathrm{cfu} / 100 \mathrm{~mL}$ before DEQ allows treated wastewater to be released. Most wastewater released contained concentrations far below that; data from the Inland Empire Utility Agency, which operates all treatment plants, indicated that total coliform concentrations in effluent do not exceed $2 \mathrm{cfu} / 100 \mathrm{~mL}$. In addition to wastewater effluent, the Orange County water deliveries to San Antonio Creek below San Antonio Dam are significant point-source discharges into the Chino Basin. These discharges are generally pristine water and not a significant source of bacteria contamination.

Most of the bacteria in the Chino Basin were derived from, and were represented in the model as, nonpoint sources. These bacteria are deposited on the land surface by many different sources (people, pets, livestock, and wildlife), and subsequently are transported to the stream network in runoff from rainfall. Primary sources are the dairies, followed by high-to-medium density residential areas, and commercial/ services, and utilities/transport. Private septic systems are few in the Chino Basin and are not a significant source of bacteria contamination.

\section{Water-Quality-Data Sources and Methods of Collection and Analysis}

\section{Pathogen Indicator Bacteria}

Pathogen indicator bacteria, which typically do not cause disease, are used to assess the microbiological quality of water because they are correlated with the presence of several waterborne disease-causing organisms. The concentration of indicator bacteria is a measure of water safety for body-contact recreation or for consumption. Wastes from warm-blooded animals contribute a variety of intestinal bacteria that are disease causing, or pathogenic, to humans. Body contact with, and consumption of water that contains, pathogens of the genera Salmonella, Shigella, and Vibrio, for example, can result in several types of disease in humans, including gastroenteritis and bacillary dysentery, typhoid fever, and cholera. Indicator bacteria, such as Escherichia coli (E. coli), in water is direct evidence of fecal contamination from warm-blooded animals, and may indicate the presence of pathogens, but cannot definitively prove or disprove the presence of human pathogenic bacteria, viruses, or protozoans. 


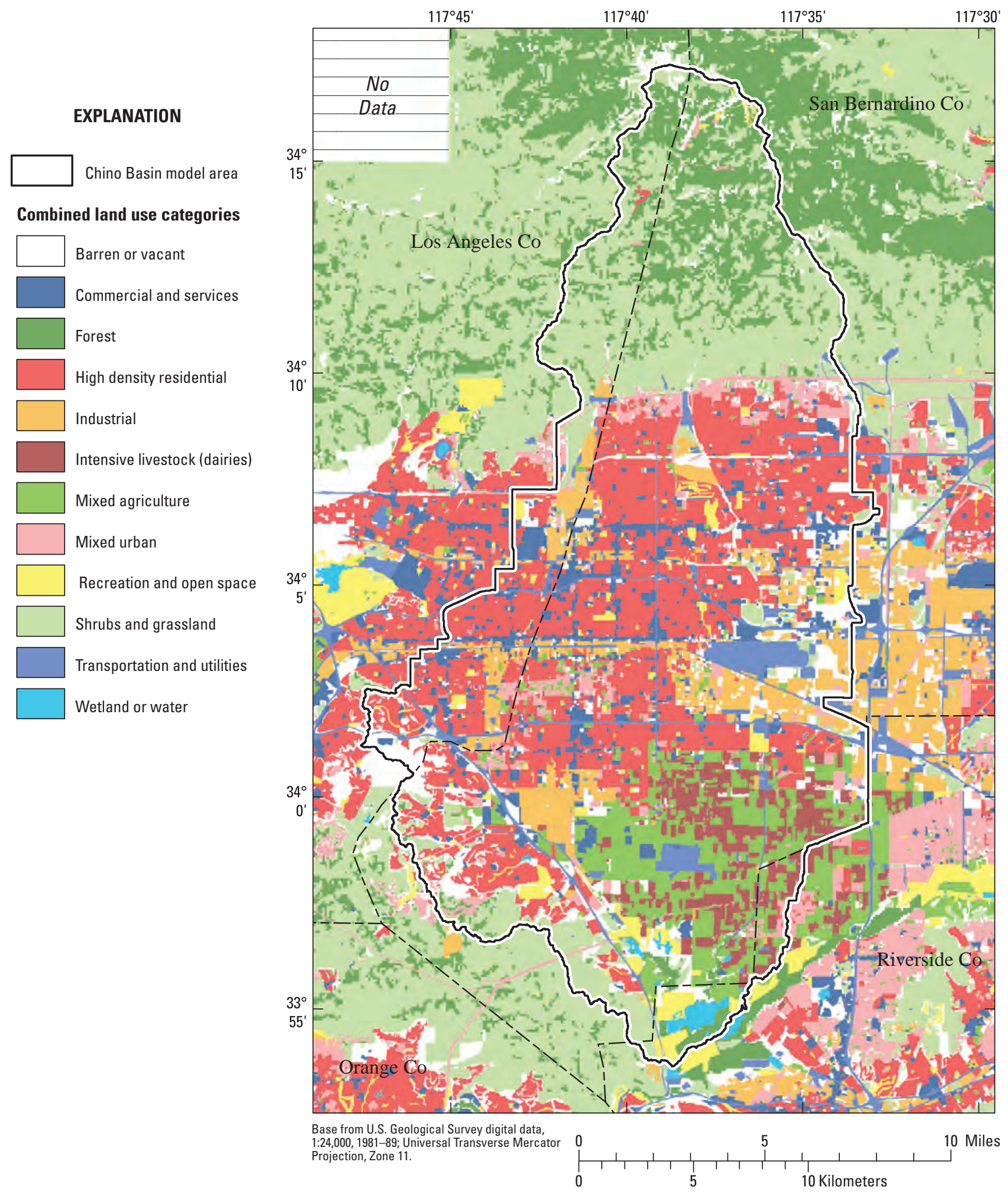

Figure 5. Land-use and vegetation categories for the Chino Basin, California. 
Water-quality criteria were developed by the U.S. Environmental Protection Agency (USEPA) in 1986 for concentrations of indicator bacteria in recreational waters, shellfishgrowing waters, and ambient waters (U.S. Environmental Protection Agency, 1986), E. coli and enterococci bacteria became the recommended indicator bacteria for recreational waters, replacing fecal coliform and fecal streptococci bacteria (U.S. Environmental Protection Agency, 1986, 2000). However, concentrations of fecal coliforms measured in the basin in 2004 were highly correlated with concentrations of measured E. coli and, although data and model parameters are included for all bacteria, fecal coliform data are used for most graphical displays and analyses in this report because fecal coliform data from other studies are available for comparison.

\section{Field Data Collection}

Samples of indicator bacteria to be analyzed were collected at the nine USGS sites in the Chino Basin (fig. 2; table 1). Indicator bacteria analyzed in this study included total coliforms, fecal coliforms, E. coli, and enterococci (Appendix 1). Membrane-filtration (MF) and most probable number (MPN) methods indicate colony forming units per 100 milliliters (cfu/100 mL), and were used to presumptively identify, confirm, and enumerate indicator bacteria. Additional analysis included colilert and enterolert microbial counting, but these methods were less reliable and were not as consistent as MF and MPN methods used in other studies of indicator bacteria concentrations in the Chino Basin and other nearby basins. The data obtained using the MF and MPN methods were used to calibrate the model.

To maintain consistency between the samples collected for this study and other samples of bacteria collected in the Chino Basin by the RWQCB, the samples for this study were analyzed by Orange County Public Health Lab (OCPHL). Approximately 10 percent of the samples were replicated to test the variability of field sampling by collecting duplicate samples in the field. Duplicate rather than split samples were collected, as required for consistency with the Orange County Health Laboratory sample processing procedures. Analyses of samples collected during the $2 / 22 / 2004$, storm indicated a difference from the mean ranging from 8 percent to 70 percent, with no apparent correlation with high- or lowdensity samples (table 2). This range indicates error in representative sampling rather than laboratory processing. Six of the eight land-use categories have errors less than or equal to 22 percent. Sixty-two duplicate lab samples were collected and tested by OCPHL during their 2002-2003 sampling, and an average of 2.5 percent difference from the mean was calculated between duplicates, indicating a variability ranging from zero to 86 percent. Additional samples were collected for total suspended sediment as a potential surrogate for indicator bacteria. Samples were also collected for turbidity, and water surface elevation (stage) measurements were made. The stage data provided qualitative information about relative discharge magnitude associated with the bacteria samples, and this was useful for model calibration. All USGS data are available in the National Water information System (NWIS) database (http://nwis.waterdata.usgs.gov/nwis).

The storm-targeted and land-use-targeted sampling locations were selected primarily to support the investigation of indicator bacteria concentrations in storm runoff from urban land and intensive feedlots (dairies). The sample locations selected for the urban land uses were also chosen according to their proximity to dairies: locations close to dairies, but not directly affected by storm runoff from dairies, and locations far from dairies. The urban land-use sites located close to dairies are RecD and RecGC (recreational land use possibly affected by dairies), ResD (residential land use potentially affected by dairies), and IndD (industrial land use potentially affected by dairies). The urban land-use sites located far from dairies are IndND (industrial land use), RecND (recreational land use), and SC (commercial and services land use).

The two sample sites representing recreational land use close to dairies were also used to investigate potential differences between different recreational land uses; the RecD site was located within a park and the RecGC was located within the area of a golf course. Four sample sites (SC, RecGC, ResD, and IndD) were located where at least 80 percent of the upstream catchment areas were covered by single land-use types. However, four other samples sites (IndND, RecND, RecD, and D) had catchments with multiple land uses, because of the difficulty in finding good sampling locations having sufficient storm-flows and representing a single land use. The catchment for site IndND was included in the residential and commercial land-use categories in addition to the industrial land-use category. The catchment for site D included mixed agriculture, transportation, and utilities categories in addition to dairies. 


\section{Application of HSPF for Evaluating Pathogen Indicators, Chino Basin Drainage Area, San Bernardino Co., California}

Table 1. Storm sampling locations and results for fecal coliforms in samples collected November 2003 and February 2004 in the Chino Basin, California.

[Densities measured in colony forming units per 100 milliliters (cfu/100 mL); \%, percent; —, no calculation]

\begin{tabular}{|c|c|c|c|c|c|c|c|}
\hline \multirow{2}{*}{$\begin{array}{l}\text { Station } \\
\text { identifi- } \\
\text { cation }\end{array}$} & \multirow{2}{*}{ Location } & \multirow{2}{*}{$\begin{array}{l}\text { Targeted } \\
\text { land use }\end{array}$} & \multirow{2}{*}{$\begin{array}{l}\text { Features of } \\
\text { catchment }\end{array}$} & \multirow{2}{*}{$\begin{array}{l}\text { Date sampled } \\
\text { water-year } \\
2004\end{array}$} & \multicolumn{2}{|c|}{$\begin{array}{l}\text { Fecal coliforms } \\
\text { (cfu/100 mL) }\end{array}$} & \multirow{2}{*}{$\begin{array}{c}\text { Number of } \\
\text { samples }\end{array}$} \\
\hline & & & & & $\begin{array}{l}\text { Geometric } \\
\text { mean }\end{array}$ & Maximum & \\
\hline$\overline{\mathrm{MC}}$ & $\begin{array}{l}\text { Mill Creek at Chino Corona } \\
\text { Road near Norco }\end{array}$ & $\begin{array}{c}\text { Integrated } \\
\text { sample }\end{array}$ & $\begin{array}{l}\text { Large, heteroge- } \\
\text { neous basin } \\
\text { with all land } \\
\text { uses }\end{array}$ & $\begin{array}{c}11 / 12-11 / 13 \\
2 / 2-2 / 3 \\
2 / 21-2 / 23\end{array}$ & $\begin{array}{r}30,047 \\
2,820 \\
3,394\end{array}$ & $\begin{array}{r}150,000 \\
7,100 \\
9,400\end{array}$ & $\begin{array}{c}20 \\
6 \\
5\end{array}$ \\
\hline IndND & $\begin{array}{l}\text { Storm drain at Francis and Grove } \\
\text { near Ontario }\end{array}$ & Industrial & $\begin{array}{l}30 \% \text { residential, } \\
60 \% \text { industry, } \\
10 \% \text { other }\end{array}$ & $\begin{array}{c}2 / 2-2 / 3 \\
2 / 22-2 / 23\end{array}$ & $-\overline{4}$ & $\begin{array}{l}4,000 \\
9,000\end{array}$ & $\begin{array}{l}1 \\
5\end{array}$ \\
\hline RecND & $\begin{array}{l}\text { Storm drain near Cypress and } \\
\text { Philadelphia near Chino }\end{array}$ & $\begin{array}{l}\text { Recreational } \\
\text { park }\end{array}$ & $\begin{array}{l}60 \% \text { park, } 40 \% \\
\text { high school } \\
\text { field }\end{array}$ & $\begin{array}{c}2 / 2-2 / 3 \\
2 / 22-2 / 23\end{array}$ & $-\overline{3,455}$ & $\begin{array}{l}7,400 \\
6,000\end{array}$ & $\begin{array}{l}1 \\
5\end{array}$ \\
\hline RecD & $\begin{array}{l}\text { Westwind park storm drain } \\
\text { near Ontario }\end{array}$ & $\begin{array}{l}\text { Park, potential } \\
\text { dairy impact }\end{array}$ & $\begin{array}{l}70 \% \text { park down- } \\
\text { stream of } 30 \% \\
\text { residential }\end{array}$ & $\begin{array}{c}2 / 2-2 / 3 \\
2 / 22-2 / 23\end{array}$ & $-\overline{1,064}$ & $\begin{array}{r}400 \\
10,000\end{array}$ & $\begin{array}{l}1 \\
5\end{array}$ \\
\hline RecGC & $\begin{array}{l}\text { Whispering Lakes golf course } \\
\text { parking lot storm drain near } \\
\text { Ontario }\end{array}$ & Golf course & $100 \%$ golf course & $\begin{array}{c}2 / 2-2 / 3 \\
2 / 22-2 / 23\end{array}$ & $\overline{233}$ & $\begin{array}{l}280 \\
830\end{array}$ & $\begin{array}{l}1 \\
5\end{array}$ \\
\hline ResD & $\begin{array}{l}\text { Storm drain near Parco and } \\
\text { Riverside at Ontario }\end{array}$ & $\begin{array}{l}\text { Residential, } \\
\text { potential dairy } \\
\text { impact }\end{array}$ & $\begin{array}{l}80 \% \text { residential, } \\
20 \% \text { school }\end{array}$ & $\begin{array}{c}2 / 2-2 / 3 \\
2 / 22-2 / 23\end{array}$ & $6, \overline{844}$ & $\begin{array}{r}6,000 \\
18,000\end{array}$ & $\begin{array}{l}1 \\
5\end{array}$ \\
\hline IndD & $\begin{array}{l}\text { Industrial park storm drain } \\
\text { near Kimball near Chino }\end{array}$ & Industrial, dairy & $\begin{array}{l}80 \% \text { dairy, } 20 \% \\
\text { industry }\end{array}$ & $\begin{array}{c}2 / 2-2 / 3 \\
2 / 22-2 / 23\end{array}$ & $\overline{89}$ & $\begin{array}{l}200 \\
320\end{array}$ & $\begin{array}{l}1 \\
5\end{array}$ \\
\hline
\end{tabular}

Table 2. Variability in fecal coliform densities from replicate samples collected on February 22-23, 2004, at various sites in the Chino Basin, California.

[Densities measured in colony forming units per 100 milliliters (cfu/100 mL)]

\begin{tabular}{|c|c|c|c|c|c|}
\hline \multirow{2}{*}{$\begin{array}{c}\text { Land use category } \\
\text { and site } \\
\text { (in parentheses) }\end{array}$} & \multirow{2}{*}{ Date } & \multirow{2}{*}{$\begin{array}{l}\text { Sample } \\
\text { location }\end{array}$} & \multicolumn{2}{|c|}{ Densities } & \multirow{2}{*}{$\begin{array}{c}\text { Percent } \\
\text { error }\end{array}$} \\
\hline & & & Sample & Replicate & \\
\hline Industrial non-dairy (IndND) & $2 / 22 / 04$ & Storm drain & 3,400 & 3,000 & 11.8 \\
\hline Recreational non-dairy (RecND) & $2 / 22 / 04$ & Storm drain & 3,800 & 6,500 & -71.1 \\
\hline Recreational non-dairy (RecND) & 2/23/04 & Storm drain & 4,200 & 3,400 & 19.0 \\
\hline Recreational non-dairy (RecND) & 2/23/04 & Storm drain & 5,800 & 6,300 & -8.6 \\
\hline Residential dairy (ResD) & $2 / 22 / 04$ & Storm drain & 2,900 & 6,000 & -106.9 \\
\hline Industrial dairy (IndD) & 2/23/04 & Storm drain & 50 & 40 & 20.0 \\
\hline Dairy (D) & $2 / 22 / 04$ & Freshwater & 37,000 & 40,000 & -8.1 \\
\hline
\end{tabular}


One storm was sampled intensively (20 samples) on 11/12/2003-11/13/203, at the Mill Creek sampling site (site $\mathrm{MC}$ ), which was a location integrating the streamflow from all the other sampling sites. It was located downstream of the USGS stream gage 11073495 (table 1 ). Storms on 2/2/2004-2/3/2004, and 2/22/2004-2/23/2004 also were sampled less intensively at this site (6 and 5 samples, respectively). The storm on 2/2/2004, was sampled once at the other 8 sampling sites, and the storm of 2/22/2004-2/23/2004 was sampled 5 times at the other 8 sampling sites. The relation between sampled bacteria concentrations at site MC (including total coliform, fecal coliforms, E. coli, and enterococci) and measured stream discharge at gage 11073495 for the 3 storms is shown in figures $6 A-C$. The results indicate a wide range in measured bacteria concentrations for total coliform and the three indicator bacteria types. For example, measured fecal coliform indicates a range of fecal coliform densities of 370 to 150,000 cfu/100 mL (Appendix 1). Graphs showing bacteria concentrations compared to stream discharge indicate a complicated relation for the 11/12/2003-11/13/2003 and the $2 / 22 / 2004-2 / 23 / 2004$ storms, whereas the graph for the $2 / 2 / 2004-2 / 3 / 2004$ storm indicates a more direct relation. However, the correlation between hourly stream discharge and bacteria concentrations, using the bacteria data for all storms and all sample sites, was weak. The correlation between turbidity and bacteria concentrations from all sample sites and during all storms was also weak.

\section{$\boldsymbol{A}$}

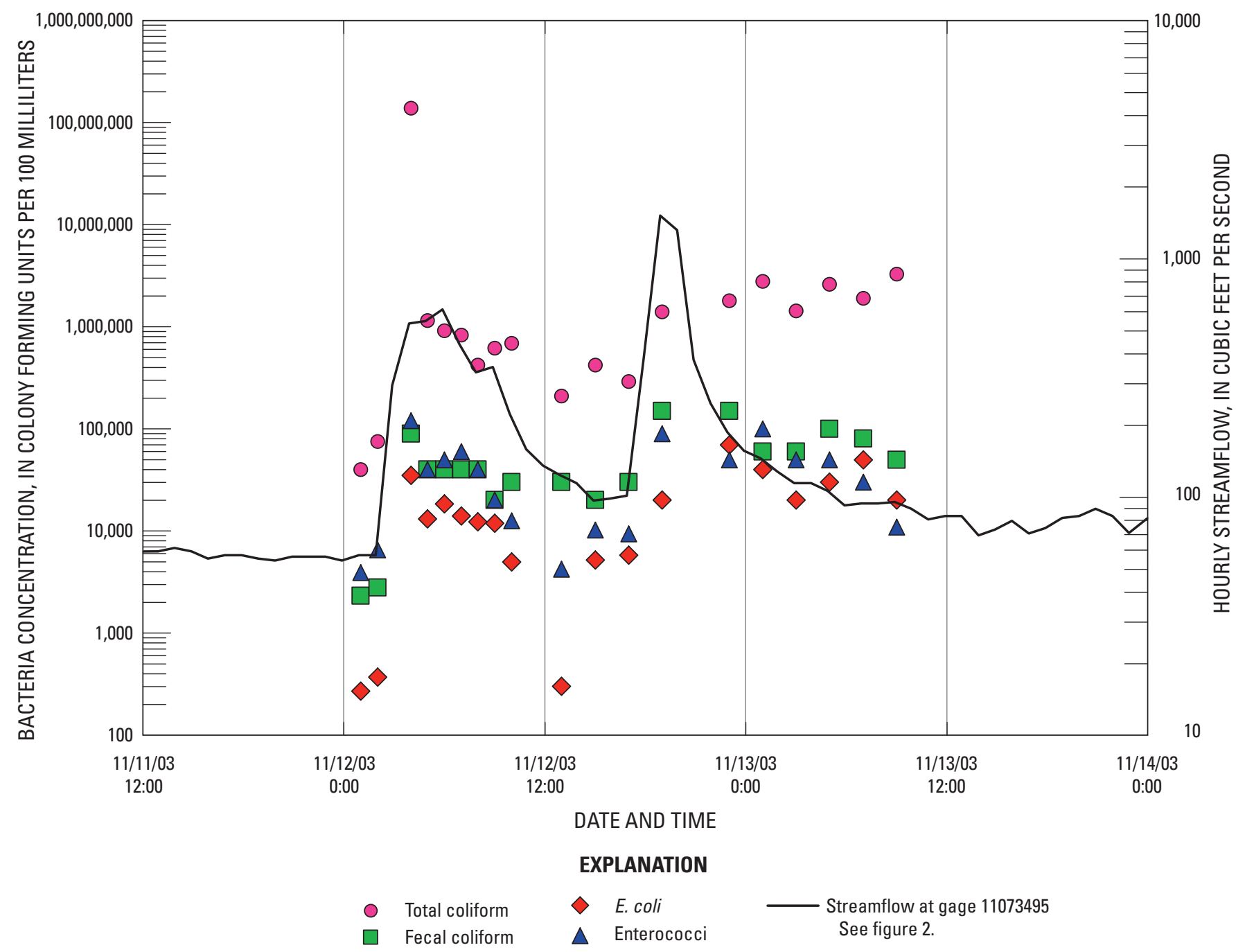

Figure 6. Measured hourly stream discharge at gage 11073495 and measured bacteria concentrations at sample site $\mathrm{MC}$ for $A$, the 11/12/2003-11/13/2003 storm, $B$, the 2/2/2004-2/3/2004 storm, and $C$, the 2/22/2004-2/23/2004 storm in the Chino Basin, California. 
Although all 4 indicator bacteria constituents were collected and used in the transport modeling analysis, only fecal coliform concentrations are given throughout the report, for simplicity and consistency with previous studies by other agencies. The relation between the measured fecal coliforms and the other three indicator bacteria constituents is shown in figure 7. As indicated, the regression lines and equations indicate strong linear relations ( $\mathrm{r}^{2}$ between 0.71 and 0.89 ) between the fecal coliform concentrations and the $E$. coli concentrations, a subset of fecal coliforms, enterococci, and total coliforms. The deviation around the regression lines indicates sampling and measurement uncertainties.

\section{Supplemental Water-Quality Data}

High concentrations of bacteria contributed to fish kills in Prado Park Lake in 1979, 1983, and 1989 and to discharge of waste-laden agricultural stormwater runoff. To investigate possible sources of these bacteria, RWQCB collected stormwater samples at 14 locations in Chino Creek and Cucamonga Creek/Mill Creek on 2/23/1993 (table 3). The data derived from this sampling indicated levels of bacteria concentration determined to be unhealthy by USEPA standards (U.S. Environmental Protection Agency, 1986). However, the 1993 storm sampling data has had a limited utility because the techniques

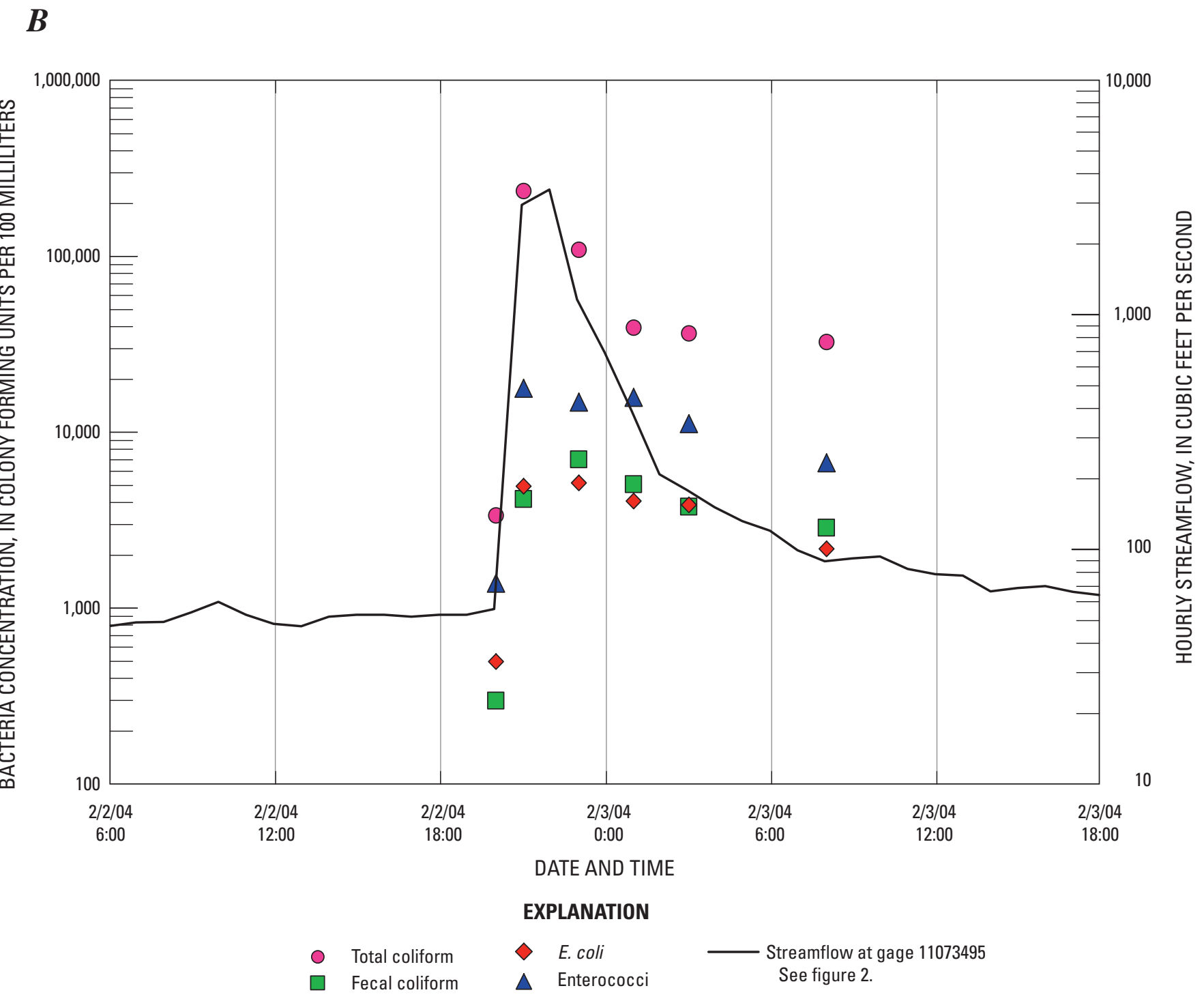

Figure 6. Continued. 
used to detect bacteria concentrations in the water samples were reliable only for indicating a lower limit to concentrations (in terms of cfu/100 mL). Samples were also collected during the winters of water-years 1997 and 1998 at 15 locations to confirm the 1993 data and evaluate bacteria densities after storm events. The 1997-98 data have higher resolution and quality than the 1993 data, having followed more rigorous analysis procedures, and provide a more quantitative dataset of bacteria concentrations for subwatersheds feeding directly into Prado Park Lake. The 1997-98 data represent runoff from agricultural areas, including dairies, downstream of the highly urbanized areas in the Chino Basin. Water samples were analyzed for total coliform and fecal coliforms only. Results indicated that stormwater runoff contained concentrations of fecal coliforms that exceeded water-quality objectives by several orders of magnitude. Locations, associated land use, and sampling dates are shown in table 3 .

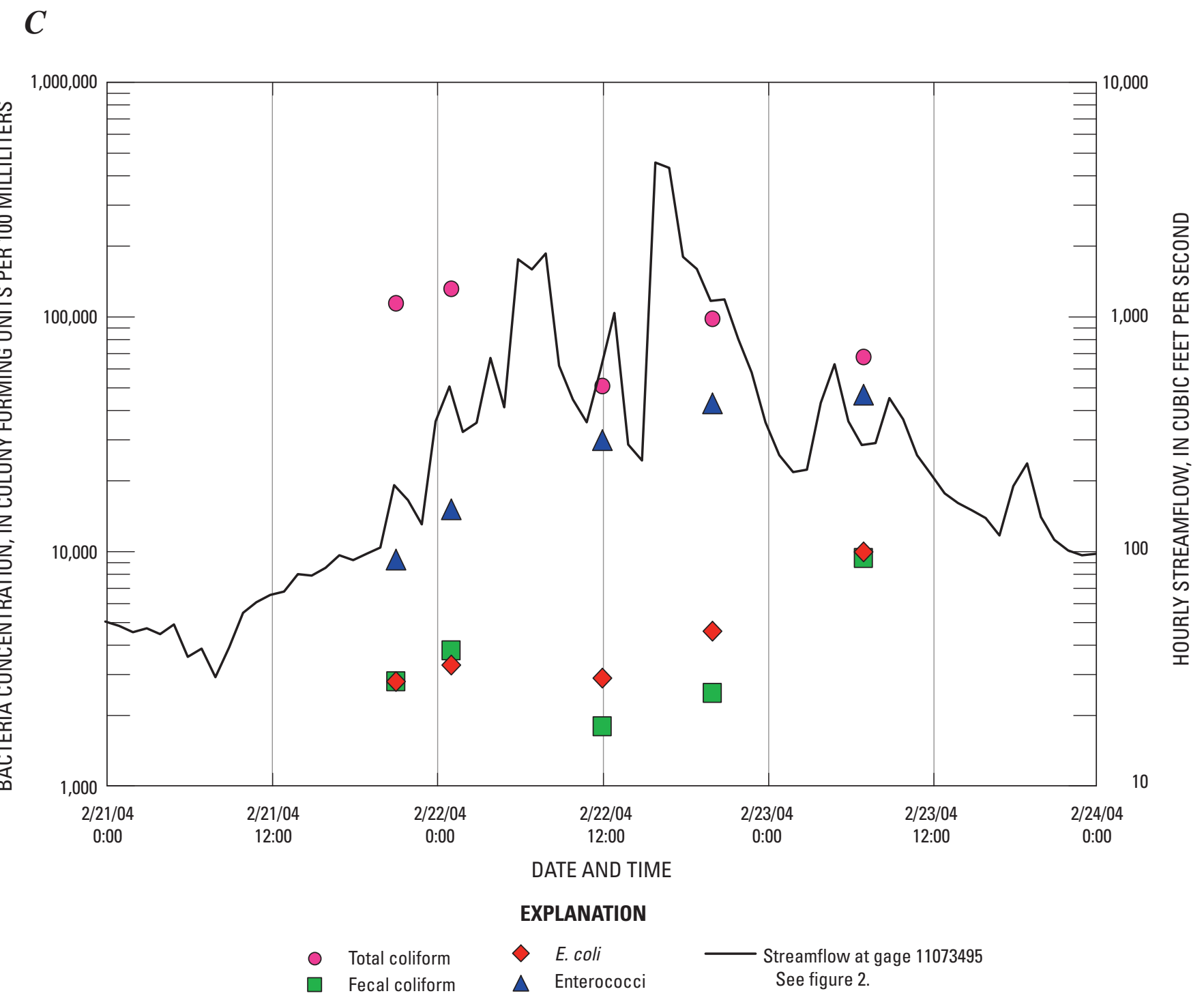

Figure 6 Continued. 


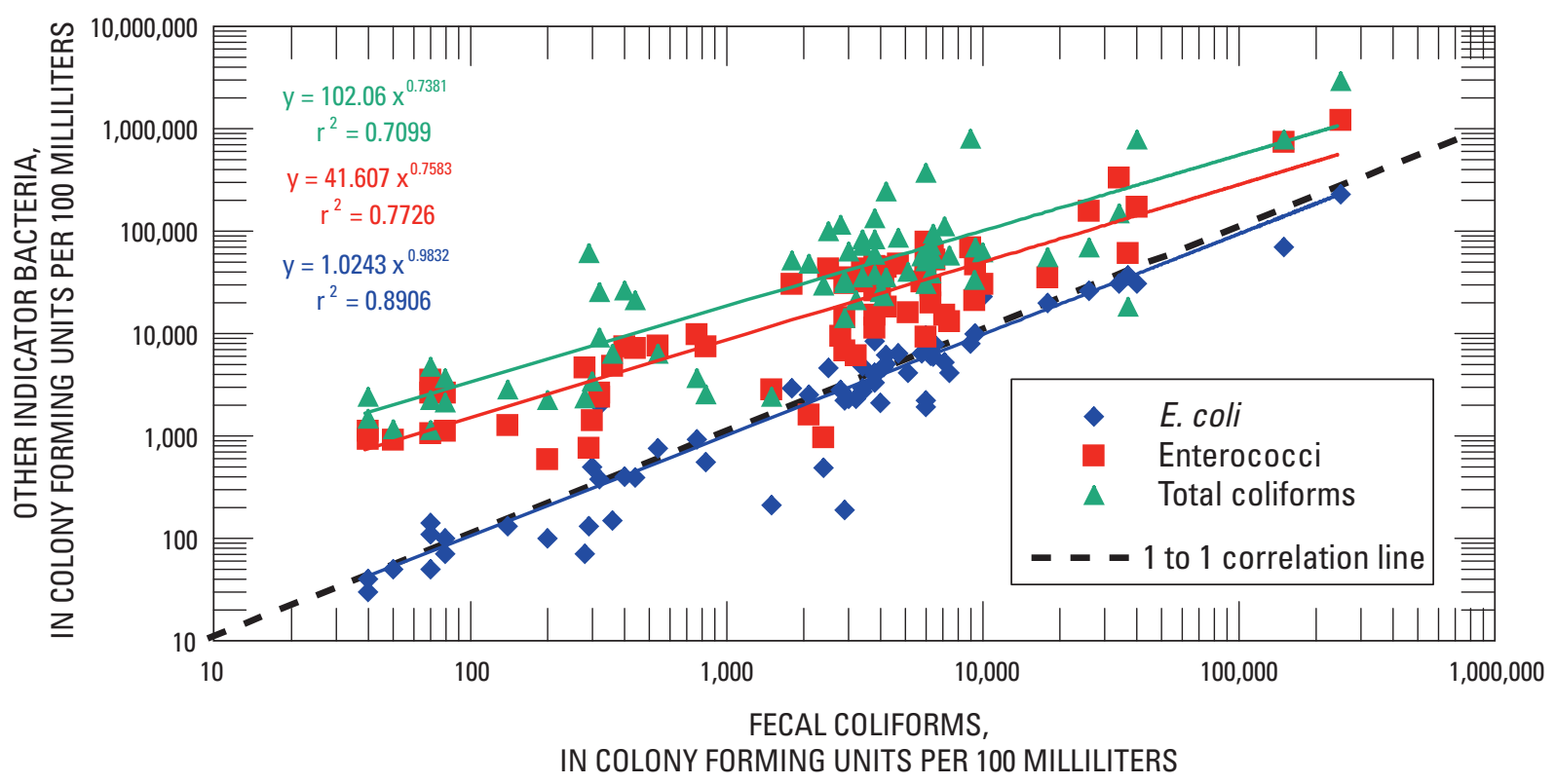

Figure 7. Measured fecal coliform data and measured E. coli, enterococci, and total coliforms for all storm sampling events in the Chino Basin, California.

To represent conditions during seasons other than those represented by samples collected during the storm events in 2003 and 2004, RWQCB established an extensive monitoring program in February 2002; water samples were collected weekly at 10 to 13 locations during nine 30-day sampling periods (table 3). Only one sample per day was collected (sampling times were usually between 10 am and $2 \mathrm{pm}$ ), but samples were collected on multiple days during each 30-day sampling period, and represented both wet-season and dryseason flows. There were 5 sites on Mill Creek and its tributaries and 6 sites on Chino Creek and its tributaries. Land uses included agriculture, urban activities, dairies, and open space. Samples were analyzed for bacteria indicators, including fecal coliform, total coliform, E. coli, and enterococcus. The results from the analyses of these samples were used to define natural background conditions and calibrate the transport model to time-averaged bacteria concentrations and to conditions before WY2004 storm targeted sampling. In addition, the RWQCB samples were useful for increasing the number of samples representing the integrated, downstream response to non-point source loading from land used for multiple purposes. Orange County Water District (OCWD) collected indicator bacteria samples during water-year 2005 at 14 sites (table 3), many of which coincided with RWQCB sites (but none of which coincided with the storm-and-land-use targeted sample sites). Concentrations of total coliform, fecal coliform, E. coli, and enterococcus in the OCWD samples were measured; the resulting OCWD data were compared with data from fecal coliform measured and simulated for water 2005, and were used to verify the calibrated bacteria transport model.

Comparison of the RWQCB fecal coliform data (including both the earlier and more recent sampling) with the data for the water-year 2004 storm-targeted samples collected for this study (plotted as daily averages) indicated a similarity in the relative magnitude and variability in measured concentrations (figure 8A). In particular, the water-year 2004 stormtargeted data is comparable to the range and variability of the 1996-98 RWQCB data, which is also representative of storm-flow conditions, whereas the water-years 2003-2004 RWQCB data includes sampling from low-flow conditions. A maximum fecal coliform concentration of approximately $100,000 \mathrm{cfu} / 100 \mathrm{~mL}$ is comparable to the maximum dailyaverage obtained for the 11/12/2003-11/13/2003 storm at the MC sampling site. Most of the storm samples fall in the range of 1,000-100,000 cfu/ $100 \mathrm{~mL}$ (or $\mathrm{mpn} / 100 \mathrm{~mL}$ ) for the two groups of storm-affected samples. Most of the 2003-2004 RWQCB data, however, ranges between 100 to $1,000 \mathrm{cfu} / 100 \mathrm{~mL}$ (or mpn/100 mL). The measured daily mean streamflow data for the upstream gaging site also falls within this range, approximately 1,000 to less than $10 \mathrm{ft}^{3} / \mathrm{s}$. 
Table 3. Supplemental water quality data and primary land uses input for model calibration, from water samples collected during 1993-2004 in the Chino Basin, California.

[TMDL, total maximum daily load (a pollution control plan); data was collected by the Regional Water Quality Control Board (RWQCB) and Orange County Water District (OCWD). CCWD, Cucamonga Creek Water District; IEUA, Inland Empire Utilities Agency; —, no data or information available]

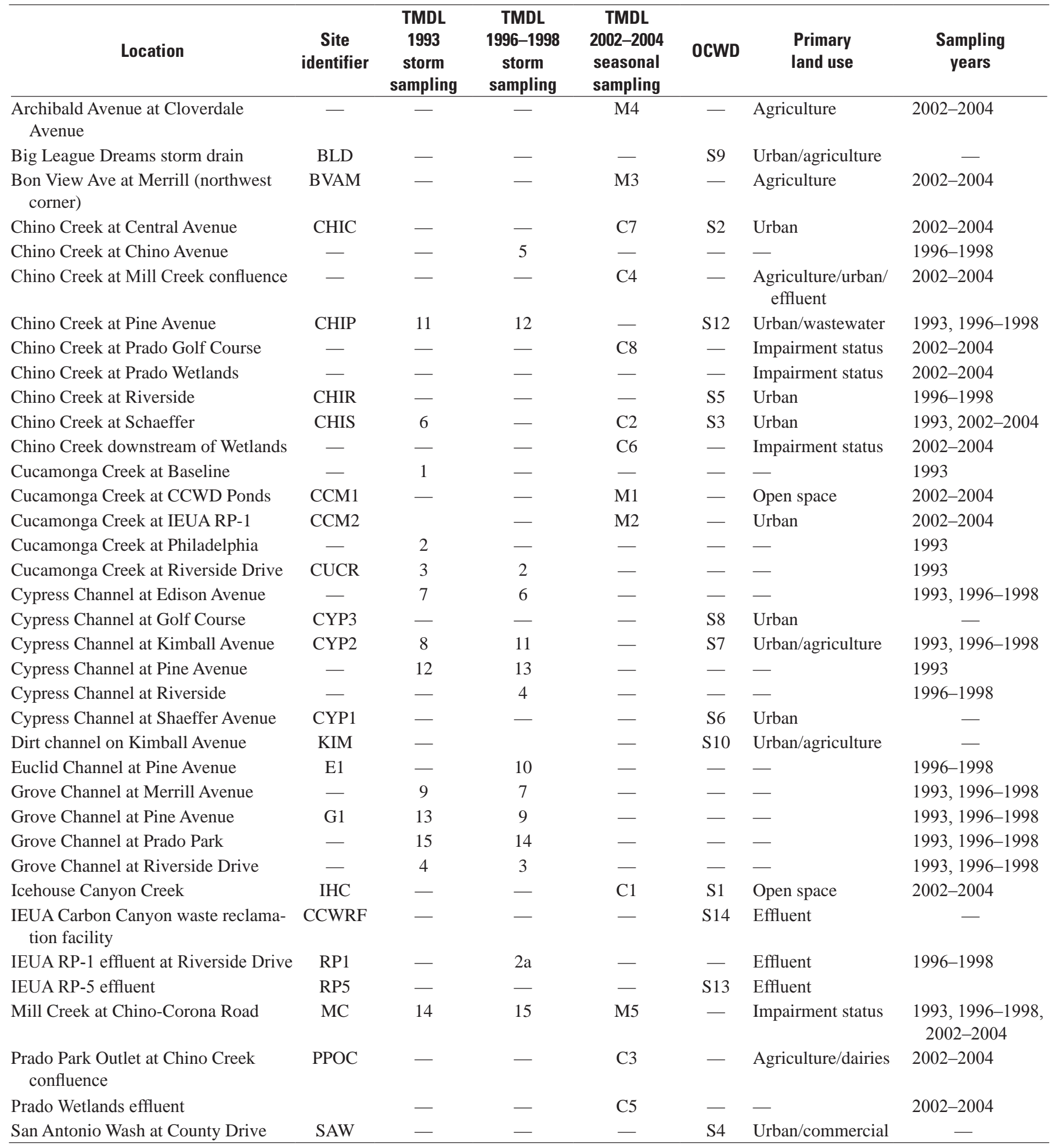


$\boldsymbol{A}$

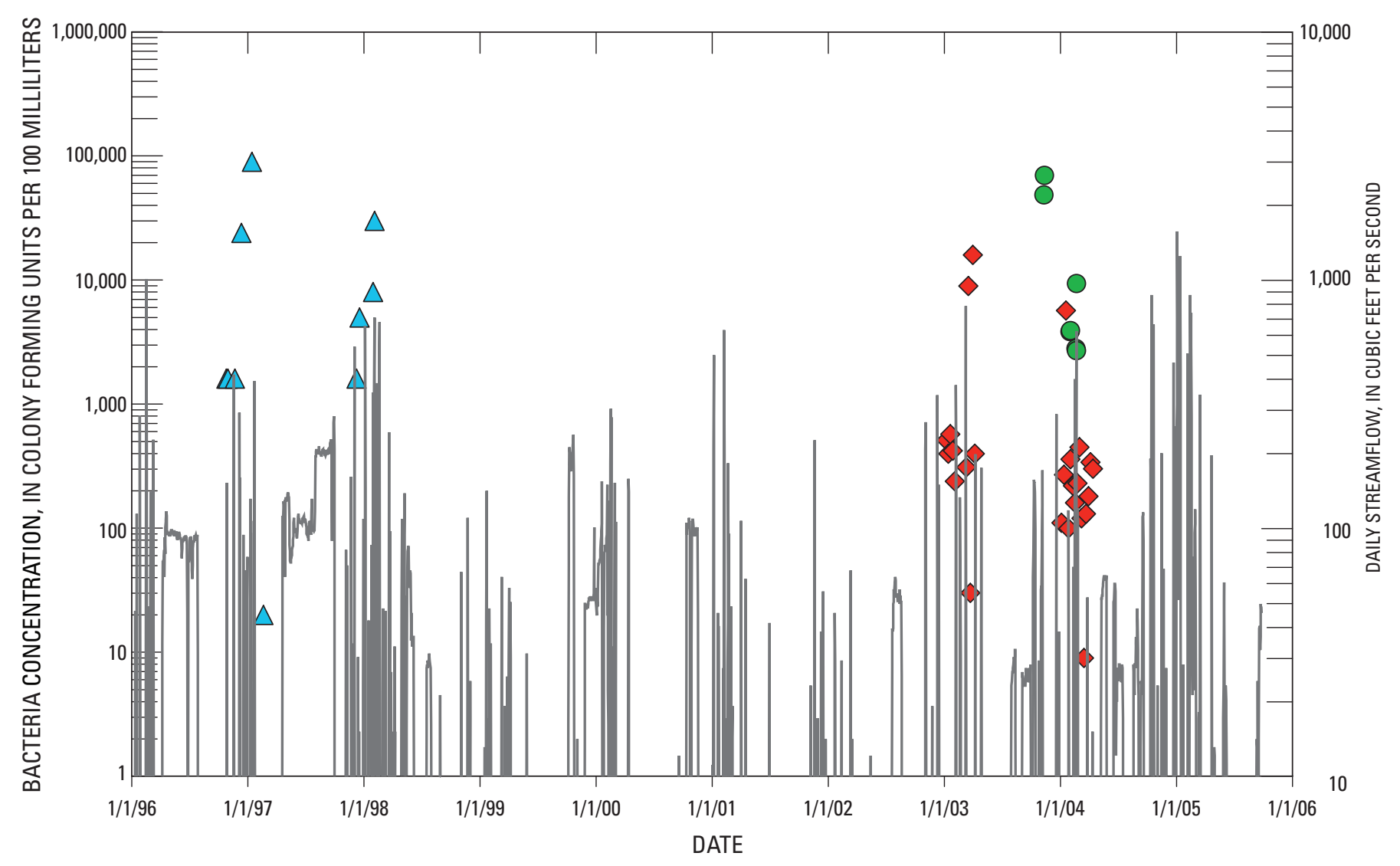

EXPLANATION

$\triangle$ Non-USGS storm samples $\quad$ USGS storm samples
$\diamond$ Non-USGS TMDL samples $\quad$ Streamflow at gage 11073495

Figure 8. Streamflow hydrographs of and measured fecal coliform bacteria concentrations for water-years 1996-2005 in $A$, daily streamflow at gage 11073495 and daily fecal coliform concentrations at site $M C$, and $B$, monthly streamflow at gage 11073360 and daily fecal coliform concentrations at sample site CHIS in the Chino Basin, California. USGS, U.S. Geological Survey; TMDL, Total Maximum Daily Load; RWOCB, Regional Water Quality Control Board; OCWD, Orange County Water Agency.

Orange County Water District (OCWD) collected indicator bacteria samples during water-year 2005 at 14 sites (table 3), many of which coincided with RWQCB sites (but none of which coincided with the storm-and-land-use targeted sample sites). The OCWD samples were measured for total coliform, fecal coliform, E. coli, and enterococcus, the OCWD data were used to verify the calibrated bacteria transport model based on a comparison of measured and simulated fecal coliform for water 2005. Comparison of the water-years 1996-1998 and water-years 2002-2004 RWQCB fecal coliform samples with the OCWD 2005 fecal coliform samples indicates the range and variability in measured bacteria concentrations between the 3 sample groups (fig. 8B). Like the historical data collected at the MC site, the RWQCB data indicates that the bacteria concentrations were higher in 1996-1998 than in 2002-2004; bacteria concentrations for the earlier group ranged from $200 \mathrm{cfu} / 100 \mathrm{~mL}$ to more than 100,000 cfu/100 mL, whereas concentrations for the later group ranged from about $10 \mathrm{cfu} / 100 \mathrm{~mL}$ to about 20,000 cfu/100 mL. The OCWD 2005 data, which includes samples collected during low-flow conditions, indicates a range of values more consistent with the 1996-1998 RWQCB data. No strong correlations between bacteria concentrations and streamflow magnitude were observed for the supplemental bacteria data. The lack of significant correlation is consistent with results obtained from previous studies. 


\section{B}

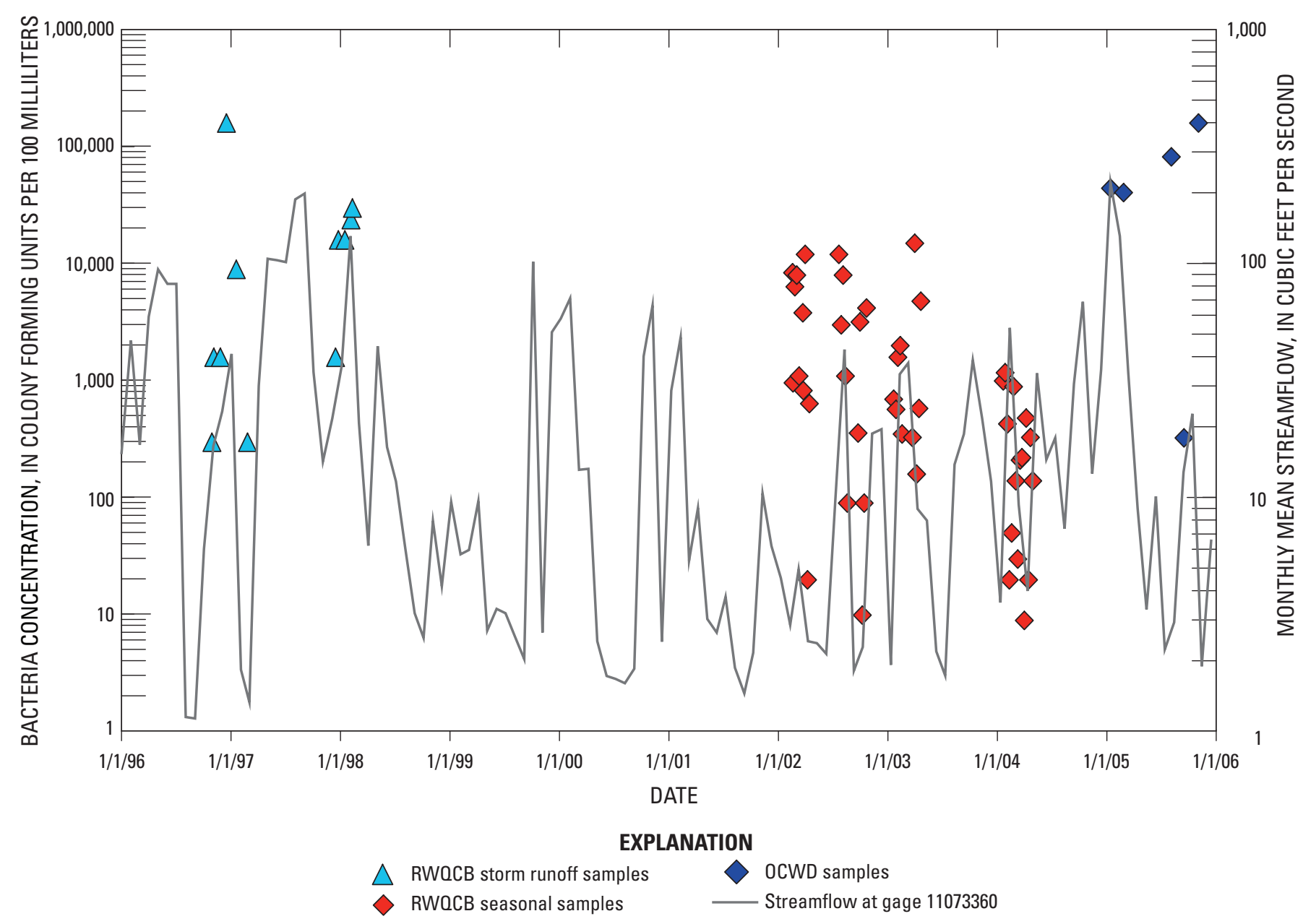

Figure 8. Continued.

Correlations between total coliform, fecal coliform, $E$. coli, and enterococcus were generally consistent with the correlations observed for the water-year 2004 storm-targeted sampling. Correlations with turbidity were not analyzed (fig. 8B).

\section{Analysis of Water-Quality Data}

The bacteria samples collected for this study and the supplemental data from other studies were generally consistent in indicating (1) highly variable concentrations of pathogen indicator bacteria in storm runoff from urban and agricultural areas; (2) indicator bacteria concentrations frequently exceeding $200 \mathrm{cfu} / 100 \mathrm{~mL}$ for both urban and agricultural runoff; (3) indicator bacteria concentrations less frequently exceeding $200 \mathrm{cfu} / 100 \mathrm{~mL}$ for runoff representing natural or background conditions; (4) high bacteria concentrations in nuisance flow; (5) average bacteria concentrations higher during storm-flow conditions than during low-flow conditions; (6) maximum bacteria concentrations ( $>1,000,000 \mathrm{cfu} / 100 \mathrm{~mL})$ in runoff from agricultural areas (including mixed agriculture and dairies); and (7) no significant correlation between bacteria concentration and hourly streamflow at nearby gages. 
The variability and magnitude of fecal coliform concentrations in the storm-flow-targeted samples collected specifically for this study were generally consistent with those in the RWQCB 1996-1998 storm flow samples. Although there was no significant correlation between bacteria concentration and hourly streamflow, storm-flow concentrations were on average higher than the low flow and seasonal concentrations in samples collected by the RWQCB during 2002-2004. Bacteria levels usually reached a maximum during storm flows. The data collected for this study did not indicate a relation between bacteria contamination and proximity to dairies for a given land use (for locations not affected by runoff from dairies). Results from multiple sampling sites having a single land use (recreation and open space, industrial) indicated high variability in bacteria concentrations, suggesting that (1) non-point bacteria loading may not be consistent or uniform for a given land use, and, (2) more frequent sampling may be needed during storm runoff to establish correlations between stormflow water quality and land use. The most conclusive results provided by the combined set of storm-flow and non-stormflow water-quality samples are that (1) bacteria concentrations in storm runoff and nuisance flow are on average much higher than natural background levels in the Chino Basin, and, (2) there is a higher frequency of bacteria concentrations greater than $200 \mathrm{cfu} / 100 \mathrm{~mL}$ in runoff from both urban and agricultural land uses than for other land uses.

\section{Data Limitations}

Model development and simulation relies on a calibration that is based on field observations of the parameters of interest; in this case, streamflow and concentrations of indicator bacteria. Except for data for storm water sampled during storms in 1992-1993 and 1996-1998, available historical data did not represent the higher flow periods during and immediately after storms. In addition, many of the historical sampling sites were not selected to target runoff from specific land uses; most of the sampling sites were located too far downstream and therefore represent an integrated response to multiple land uses.

Storm-water data collected by the USGS for this study were incorporated into the model calibration process to provide information on the response of indicator bacteria concentrations (fecal coliforms, E. coli, total coliforms, and enterococci) during stormflows. Most of the data were for storm runoff from relatively small catchments (as small as 3 acres) that represented specific urban land uses. Uncertainties in collecting the water-year 2004 storm samples include lack of laboratory duplicates, and collecting single samples at each field location may not reflect cross-sectional averages in a stream. The size of the sample of indicator bacteria data was too small to enable relative land-use contributions for all land uses defined in the model to be assessed. The data did not provide a direct measure of land-use-specific bacteria loading rates, storage capacities, and washoff limits, but model calibration was required to define the parameters controlling bacteria accumulation and transport, and relied on default and historical model parameters as initial estimates, such as those indicated in table 4.

Bacteria sampling techniques, including both field methods and laboratory analysis, have evolved throughout the period during which the data used in the study were collected. A direct comparison of bacteria concentrations obtained using different sampling techniques is not always possible. For example, data obtained for the 1993 and 1996-1998 stormwater study has lower resolution than data obtained during 2004 and 2005 because of improvements in sampling techniques. Data indicated that bacteria concentrations collected by OCWD at the same sites appeared to be higher in WY2005 than in earlier years, but this may be caused by differences and improvements in sampling techniques as opposed to actual trends.

\section{Simulation of Streamflow and Bacteria Transport}

\section{Description of Model}

The computer code Hydrologic Simulation Program FORTRAN (HSPF) version 12 (Bicknell and others, 1997) a lumped-parameter, continuous-simulation watershed model — was chosen to simulate the streamflow and the indicator bacteria transport in the Chino Basin. HSPF simulates the transport and storage of water and associated water-quality constituents by routing observed precipitation by way of watershed surface, soil, and instream processes (Donigian and others, 1995). HSPF represents the mechanisms of transport and storage within distinct modules for three unique model elements: pervious land segments (PERLND), impervious land segments (IMPLND), and stream channels (RCHRES). These hydrologic transport mechanisms vary naturally because of spatial changes in watershed characteristics such as topography, land use, and soil properties; HSPF accounts for this variability by simulating runoff from smaller, more homogeneous parts of the watershed that are linked by interconnected channel segments. Thus, for modeling purposes, the watershed was disaggregated into segments having similar climatic and topographical characteristics. Each subwatershed was refined further into hydrologic response units (HRU) that represent areas, within each land segment, with similar watershed characteristics, such as land use. 


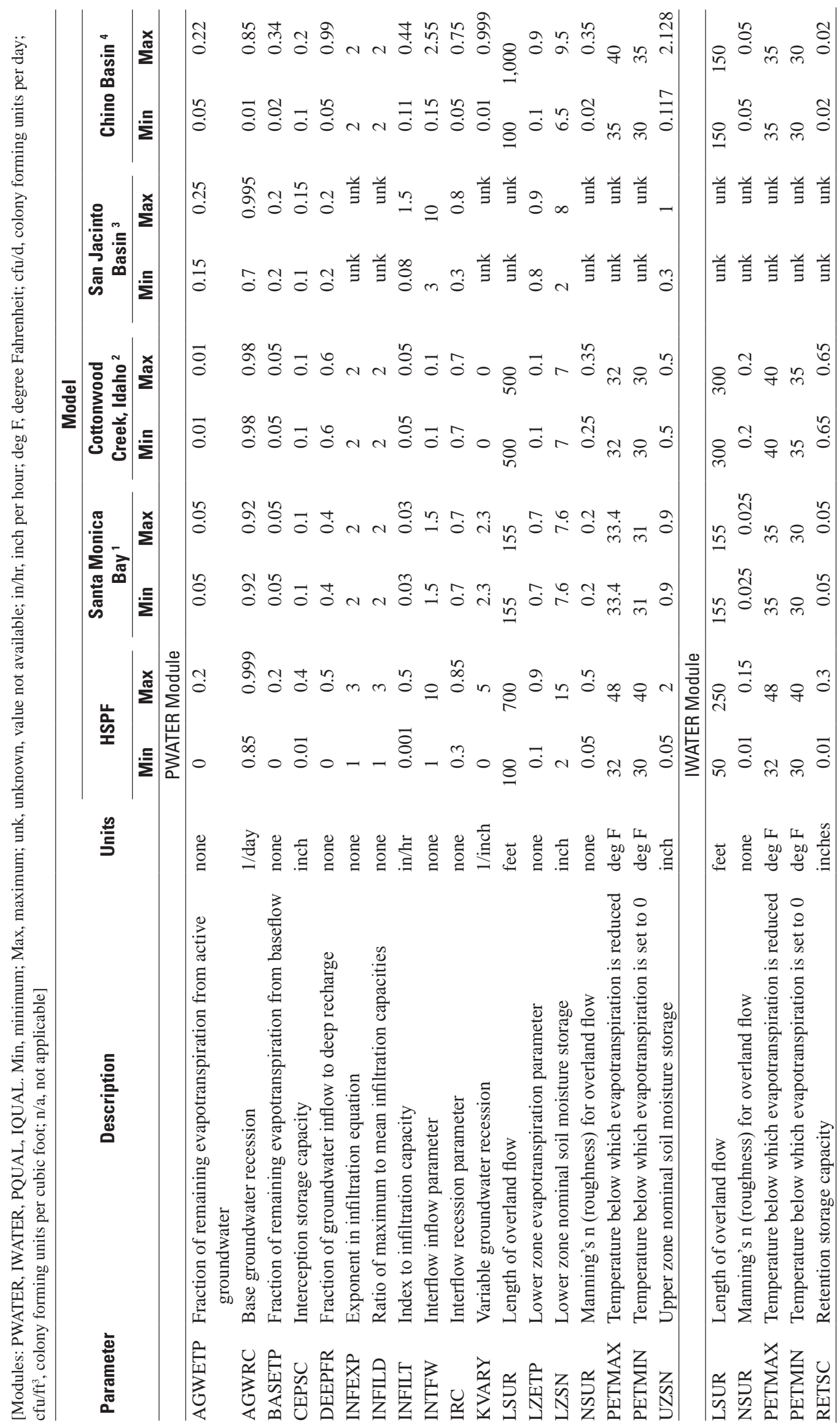




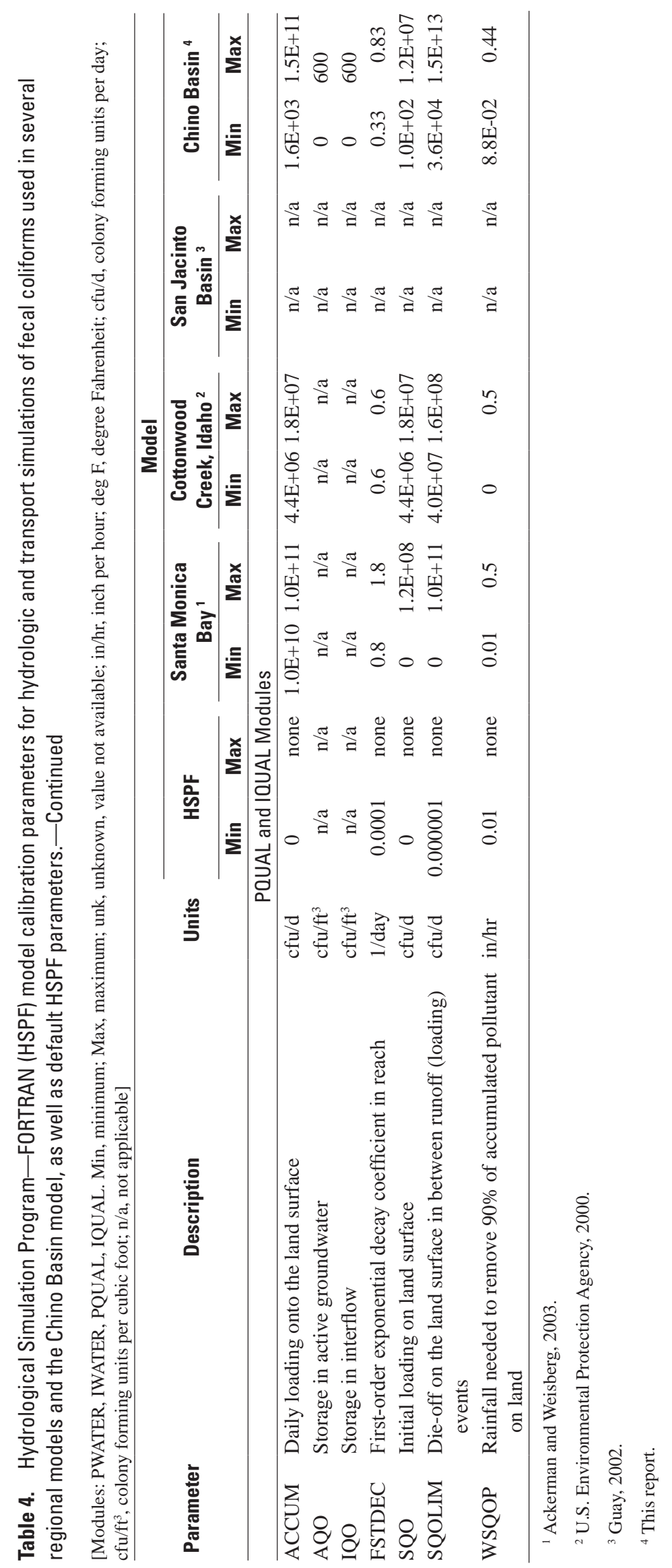


In each stream reach in the model, water from PERLNDs was supplied to the reach as overland flow, interflow (shallow subsurface flow), or baseflow (ground-water discharge); from IMPLNDs as overland flow; from point sources as sewagetreatment plant effluent or dam releases and from upstream channel reaches as streamflow. All water was assumed to enter the separate stream reaches at a single, upstream point. The impervious fraction was broken into two categories: "hydrologically effective" and "hydrologically ineffective" (Zarriello, 1999). Hydrologically effective areas drain directly to stream channels and were represented by the IMPLND (impervious lands) module. Hydrologically ineffective areas drain onto pervious land types, such as grassland or forest, and were better represented by the PERLND module.

The hydrological processes acting on a PERLND are considerably more complex than those acting on an IMPLND and were represented by a hydrologic water-budget module (PWATER) that included model parameters for water storage and transport along both surface- and subsurface flow paths. The hydrologic water-budget module for processes affecting an IMPLND (IWATER) is much simpler than the PWATER module because there are no subsurface flow paths. Precipitation interception by features that extend above the IMPLND (urban vegetation and rooftops for example) is described by an impervious retention-storage parameter (RETS). Other hydrologic parameters for surface runoff are the same in IWATER and PWATER. Many of the hydrologic parameters for both PWATER and IWATER were adjusted during calibration to simulate the hydrologic routing through each HRU that was determined from GIS analysis using ArcGIS. These are defined in table 4. More detailed descriptions of the modules, pathways, and parameters are given by Moyer and Hyer (2003).

Although bacteria transport in a watershed is closely tied to hydrologic processes, the concentrations at any location also depend heavily upon the initial supply from land-surface and point sources and the rate of die-off. The HSPF model simulates the transport of indicator bacteria from pervious land surfaces using a PQUAL (water quality on pervious land units) module similar to the hydrologic PWATER module. Thus, PQUAL simulates the storage and transport of bacteria along surface and subsurface flow paths. Seven bacteria-transport parameters are used in the PQUAL and IQUAL (water quality on impervious land units) modules for simulation (fig. 9; table 4) and are run through 3 algorithms representing surface flow (SOQUAL), interflow (IOQUAL), and baseflow (AOQUAL) processes. Bacteria transport from impervious surfaces is simulated using an IQUAL module. The processes and routing parameters in IQUAL are identical to those in PQUAL for the surface-transport component.

Water that enters each reach was assumed to flow downstream as a kinematic wave (Martin and McCutcheon, 1999). Flow characteristics are governed by such channel morphological parameters as cross-sectional area, roughness, and slope. These parameters were measured in the field or estimated from aerial photos and used to develop a function table (FTABLE) module that related stage to discharge at each end of the reach and provided reach values for channel water-surface area and volume. Except for a portion that dies off over time, bacteria that enter a stream reach were presumed to travel downstream with the water to the next reach. The die-off rate (parameter REMQOP) was a fixed first-order decay rate of 1.1 day $^{-1}$ (U.S. Environmental Protection Agency, 1985). Every source represented in the model had a specific fecal coliform accumulation rate (represented by the ACCUM parameter). The total accumulation rate of fecal coliform bacteria on the land surface was bounded by a storage limit that enabled the model to account for the natural die-off of bacteria stored on the land surface. For this study, the storage limit (SQOLIM) was set to 1.8 times the accumulation rate, which represents a decay rate of 0.55 day $^{-1}$ (U.S. Environmental Protection Agency, 1985).

The most critical limitation associated with the HSPF bacteria-transport model developed for this study was that pathogen indicator bacteria were simulated as a dissolved constituent. Bacteria, however, are particulate constituents and are deposited and re-suspended once delivered to the active stream channel. The transport mechanisms associated with deposition and resuspension were not simulated explicitly. Although HSPF can simulate bacteria as particulate constituents using a combination of sediment transport and water-quality modules, these methods were not applied in this study because of the need for additional model parameters for sediment transport and a lack of available data to support the parameterization. Other studies simulating bacterial transport using HSPF have had successful results despite this limitation (Moyer and Hyer, 2003; Yagow and others, 2001), and have suggested addressing bacteria as dissolved constituents. In the advective transport model used for this study, the resuspension of bacteria was implicitly represented by interflow and baseflow transport used primarily in the northern mountainous parts of the Chino Basin. For this study, interflow and baseflow transport were used in order to also provide at least some representation of point sources affecting baseflow in the mountainous drainages.

Interflow and baseflow in the central and southern parts of the Chino Basin were not included in the model, except for a small amount of throughflow in the southernmost part. Instead, an assumed nuisance flow (flow originating as small inflow from urbanized areas) was added to each reach having urban or agricultural land use in the land segment contributing runoff to that reach. The nuisance flow was modeled as a specified point-source inflow (to the upstream node of the reach) rather than as a specified overland flow component, because of a lack of data specifying nuisance flow for the 12 PERLNDs and IMPLNDs. The specified nuisance flow was used to implicitly represent contaminated runoff from the land units during the dry periods between storms, as well as point sources and re-suspension or regrowth of bacteria in reaches. Although this method likely over-simplifies processes controlling bacteria loading and transport in the reaches, the inclusion of contaminated nuisance flow was supported by the field data and thus was preferred to assuming nuisance flow was pristine. 


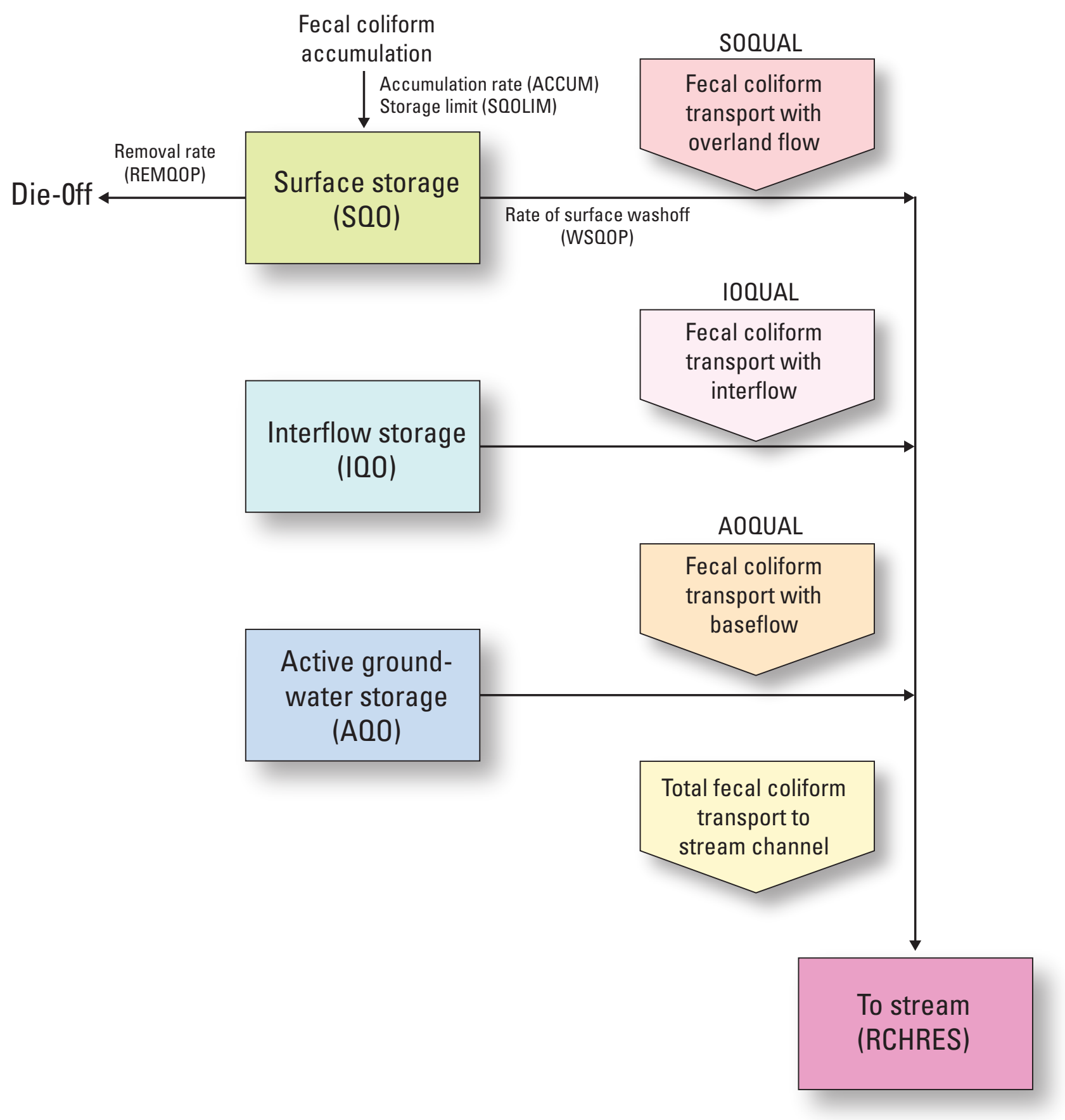

Figure 9. Routing processes represented by the Hydrological Simulation Program-FORTRAN code for the simulation of fecal coliform bacteria transport and storage parameters. SQ0, initial loading on land surface; I00, storage in interflow; A00, storage in active ground water; SOQUAL, algorithm representing surface flow processes; IOQUAL, algorithm representing interflow processes; AOQUAL, algorithm representing baseflow processes. 


\section{Subwatershed Delineation}

The topography and drainages of the Chino Basin were determined from a 10-m digital elevation model into which the urban drainage features were incorporated. Topographic features contributing to basin drainage were defined using the ARC/GIS module Arc/Hydro. To simulate streamflow and bacteria transport, the basin was delineated into 229 small single-reach, interconnected hydrologic response units. Although this degree of watershed disaggregation was greater than that used in similar HSPF modeling studies, the delineation of so many channel reaches enabled the simulation of runoff and transport through a complex network of urban drainage features, such as constructed channels and storm drains, and natural channels. Once the 229 channel reaches and the associated hydrologic response units had been determined, they were recombined into 46 larger base model segments (fig. 10), each of which had relatively uniform upper boundary conditions for input of air temperature and precipitation. These distributions represent the spatial variability of climatic conditions in the basin (figs. $4 A, B$ ). Average annual precipitation and air temperature for each of the 46 segments indicate the variability of upper boundary conditions in the Chino Basin (table 5). The data presented in the table are the averages for 1970-2005. The 46 model segments were further recombined into 5 subbasins that were represented by 5 separate submodels. These were intended to optimize hydrologic model calibration and verification at the 4 USGS streamflow gaging stations and 2 sampling sites at the San Antonio dam and provide simulated flow and transport characteristics at the mouths of the 4 streams in the Chino Basin (fig. 11). The San Antonio Canyon subbasin is characterized by natural (background) conditions for bacteria generation; two sampling sites, Ice House Canyon (IHC) and Cucamonga Canyon M1 (CCM1) (table 3) were used to calibrate the model for land uses representing natural-background conditions (shrubs/grasslands, woodlands, and barren/vacant).

Once model calibration was complete, the model was applied for the entire Chino basin to test various scenarios. To simplify discussion on the basis of hydrologic boundaries, the model segments were recombined into four hydrologic subbasins: San Antonio Canyon subbasin, Chino Creek subbasin, Mill Creek subbasin, and Prado Basin subbasin (fig. 12).

The Chino Creek subbasin has several characteristics that distinguish it from the Mill Creek subbasin. The Chino Creek drainage includes several less-engineered drainages along the northeastern slope of the Chino Hills, and the lower reaches of Chino Creek are more characteristic of natural stream channels than concrete lined channels. The Mill Creek subbasin contains a higher percentage of concrete-lined engineered channels in the central and southern part of the Chino Basin than the Chino Creek subbasin. Streamflow from the mountain drainages in the northern part is captured in numerous retention basins and spreading grounds. Downstream of the mountain front, retention basins capture streamflow from the main channels. The Prado Basin subbasin is within the Prado Dam storage basin and is subject to flooding. In addition, the subbasin contains the Orange County engineered wetlands, which includes inflows from the Santa Ana River. The complex hydrology of the subbasin was not explicitly represented by the HSPF bacteria-transport model. Rather, the subbasin was defined only to integrate the outflows from Chino Creek and Mill Creek subbasins into a single pour point simulating inflow from the Chino Basin to the Santa Ana River. Because of the greater uncertainty associated with simulating the Prado Basin subbasin, model results presented in this report are limited to the San Antonio, Chino Creek, and Mill Creek subbasins.

\section{Input Data}

\section{Channel Reach Data}

Channel properties were defined using a combination of data sources. Descriptive information for the San Antonio Creek, Chino Creek, Cucamonga Creek, and Mill Creek channels was obtained from previous reports (U.S. Army Corps of Engineers, 1991; Wildermuth Environmental, Inc., 2003; Belitz and others, 2004; Izbicki and others, 2004; Rice, 2005). A detailed drainage network map for the Chino Basin was provided by the San Bernardino County Flood Control District, including geometry and channel type attributes for all channels. A storm drain map for the southeastern section of the Chino Basin within Riverside County was provided by the Riverside County Flood Control District. Photographs, field visits, and digital orthophotos were also used to help determine channel properties for all reach segments represented in the HSPF model. Estimates of channel roughness (Manning's n) were made on the basis of published data for concrete channels, and channel median grain size, irregularity (width to depth ratios), alignment (abrupt changes in channel width), obstructions (debris), and vegetation (instream and bank vegetation) for natural channels. Channel slope was estimated by dividing the change in elevation from the upstream to the downstream ends of a reach by the reach length determined using hydrography and elevation data in GIS. Cross-section measurements, estimates of channel roughness, and slope calculations were used in WinHSPF (the Windows-based preprocessor for HSPF) to generate FTABLEs. Modeled streams are shown in figures 11 and 12 . 


\section{EXPLANATION}

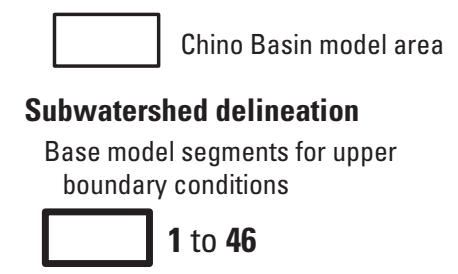

\section{Hydrologic response units}

Colors vary with overlaid precipitation

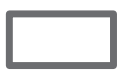

Average January precipitation, in inches
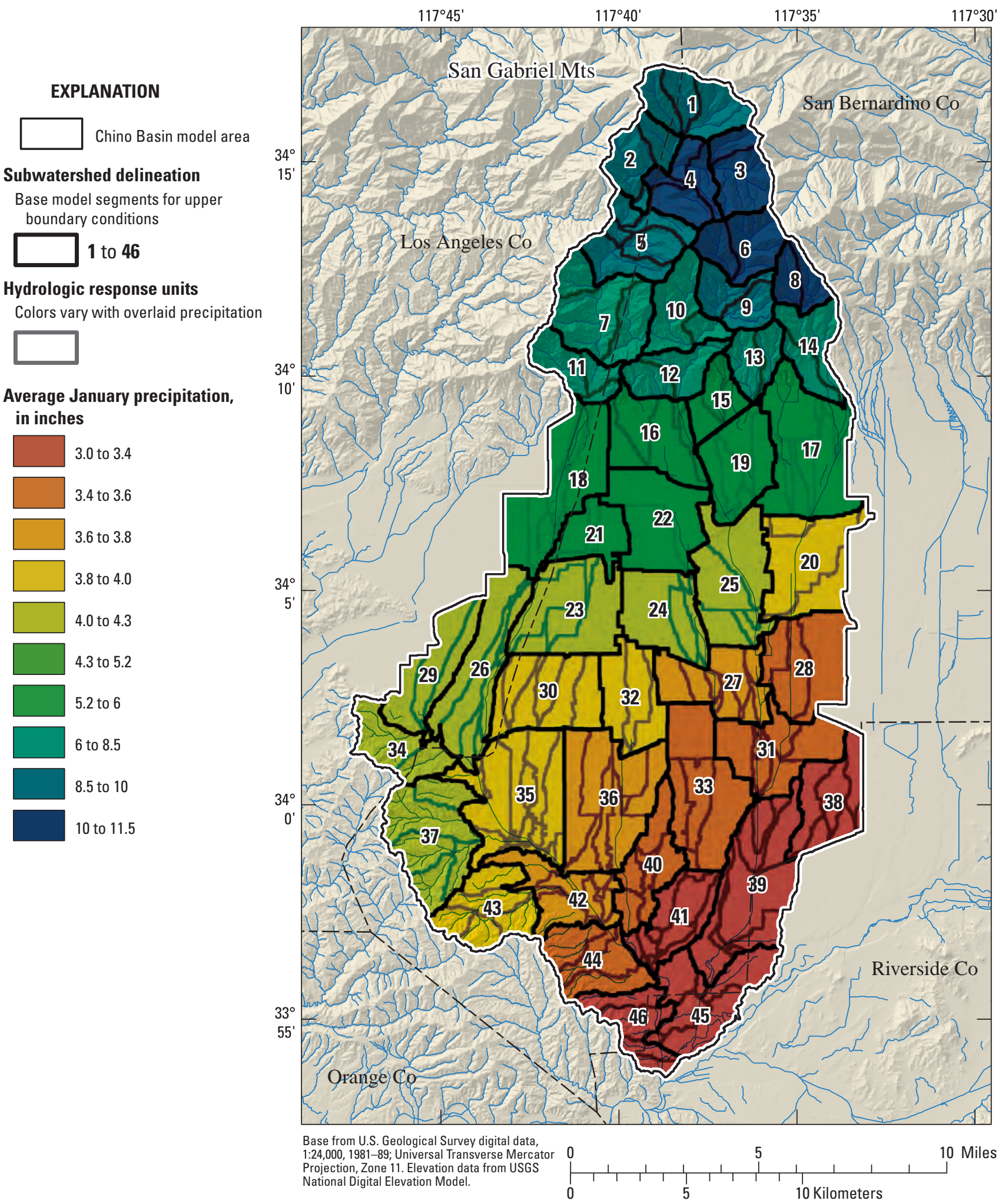

Figure 10. Base model segmented by average precipitation in January, and delineated hydrologic response units for each reach in the Chino Basin, California. 
Table 5. Average values for precipitation and air temperature for 46 model segments used for the Chino Basin model, 1970-2005.

[For locations, see fig. 10]

\begin{tabular}{|c|c|c|c|c|c|c|c|}
\hline \multirow{2}{*}{$\begin{array}{c}\text { Model } \\
\text { segment } \\
\text { number }\end{array}$} & \multicolumn{4}{|c|}{ Precipitation (in inches) } & \multicolumn{3}{|c|}{ Precipitation (in inches) } \\
\hline & $\begin{array}{c}\text { Average } \\
\text { annual }\end{array}$ & $\begin{array}{c}\text { Maximum } \\
\text { annual }\end{array}$ & $\begin{array}{c}\text { Minimum } \\
\text { annual }\end{array}$ & $\begin{array}{l}\text { Maximum } \\
\text { daily }\end{array}$ & $\begin{array}{l}\text { Average } \\
\text { daily }\end{array}$ & $\begin{array}{c}\text { Maximum } \\
\text { monthly }\end{array}$ & $\begin{array}{c}\text { Minimum } \\
\text { monthly }\end{array}$ \\
\hline 1 & 37.8 & 86.4 & 11.4 & 9.3 & 42.1 & 63.0 & 24.9 \\
\hline 2 & 36.0 & 83.5 & 9.8 & 8.9 & 45.3 & 66.3 & 27.8 \\
\hline 3 & 43.3 & 99.3 & 12.0 & 10.7 & 42.3 & 62.9 & 25.4 \\
\hline 4 & 38.8 & 89.8 & 10.0 & 9.7 & 45.1 & 65.9 & 27.9 \\
\hline 5 & 34.5 & 79.8 & 9.1 & 8.8 & 49.1 & 70.0 & 31.6 \\
\hline 6 & 42.5 & 97.3 & 11.9 & 10.8 & 45.8 & 66.2 & 28.9 \\
\hline 7 & 29.1 & 66.8 & 8.3 & 7.5 & 54.1 & 74.6 & 36.3 \\
\hline 8 & 41.6 & 94.5 & 12.4 & 10.7 & 49.3 & 69.4 & 32.6 \\
\hline 9 & 36.3 & 82.9 & 10.5 & 9.3 & 50.2 & 70.3 & 33.2 \\
\hline 10 & 31.8 & 72.9 & 9.1 & 8.2 & 51.1 & 71.3 & 33.7 \\
\hline 11 & 25.3 & 57.2 & 7.1 & 6.7 & 59.0 & 78.9 & 41.3 \\
\hline 12 & 24.8 & 56.6 & 7.0 & 6.4 & 55.6 & 75.4 & 38.3 \\
\hline 13 & 28.5 & 64.6 & 8.7 & 7.5 & 54.7 & 74.5 & 37.8 \\
\hline 14 & 31.4 & 70.5 & 9.8 & 8.4 & 54.4 & 74.1 & 37.7 \\
\hline 15 & 22.0 & 50.1 & 6.8 & 5.8 & 56.7 & 76.2 & 39.7 \\
\hline 16 & 19.6 & 44.1 & 6.1 & 4.9 & 57.6 & 76.9 & 40.6 \\
\hline 17 & 19.3 & 43.3 & 6.4 & 5.5 & 61.3 & 80.4 & 44.9 \\
\hline 18 & 18.3 & 40.5 & 2.3 & 5.6 & 61.0 & 79.9 & 44.3 \\
\hline 19 & 18.2 & 41.4 & 5.9 & 4.9 & 61.3 & 80.4 & 44.8 \\
\hline 20 & 14.7 & 34.2 & 4.2 & 4.6 & 63.2 & 81.7 & 47.5 \\
\hline 21 & 16.5 & 39.0 & 5.6 & 4.3 & 61.7 & 80.3 & 45.3 \\
\hline 22 & 16.5 & 37.4 & 5.6 & 4.1 & 61.8 & 80.6 & 45.4 \\
\hline 23 & 14.3 & 35.7 & 4.1 & 4.0 & 62.3 & 80.0 & 46.7 \\
\hline 24 & 14.0 & 32.7 & 4.7 & 4.0 & 62.9 & 80.7 & 47.3 \\
\hline 25 & 14.8 & 34.7 & 4.1 & 4.6 & 62.9 & 81.2 & 47.1 \\
\hline 26 & 14.6 & 33.4 & 4.8 & 3.9 & 62.3 & 78.9 & 47.4 \\
\hline 27 & 13.0 & 31.0 & 3.6 & 3.8 & 63.7 & 81.2 & 48.7 \\
\hline 28 & 12.8 & 30.1 & 3.0 & 4.2 & 64.2 & 82.1 & 49.2 \\
\hline 29 & 14.7 & 32.9 & 4.8 & 3.9 & 62.2 & 78.3 & 47.4 \\
\hline 30 & 13.8 & 32.8 & 4.7 & 4.0 & 62.8 & 79.6 & 47.9 \\
\hline 31 & 12.2 & 28.7 & 3.4 & 3.4 & 64.2 & 81.6 & 49.8 \\
\hline 32 & 13.2 & 31.7 & 4.3 & 3.7 & 63.2 & 80.4 & 48.4 \\
\hline 33 & 12.3 & 29.0 & 3.4 & 3.3 & 63.9 & 80.8 & 49.7 \\
\hline 34 & 14.9 & 32.9 & 4.9 & 4.0 & 62.4 & 78.0 & 48.3 \\
\hline 35 & 14.2 & 33.0 & 4.7 & 4.7 & 63.0 & 79.3 & 48.9 \\
\hline 36 & 13.0 & 31.1 & 3.9 & 4.5 & 63.4 & 80.0 & 49.4 \\
\hline 37 & 14.9 & 32.9 & 4.8 & 4.3 & 62.6 & 78.7 & 49.0 \\
\hline 38 & 11.7 & 27.3 & 3.6 & 3.0 & 64.5 & 81.9 & 50.3 \\
\hline 39 & 11.5 & 26.7 & 3.1 & 2.9 & 64.1 & 81.1 & 50.4 \\
\hline 40 & 12.5 & 28.7 & 2.6 & 3.5 & 63.7 & 80.3 & 50.0 \\
\hline
\end{tabular}


Table 5. Average values for precipitation and air temperature for 46 model segments used for the Chino Basin model, 1970-2005.Continued

[For locations, see fig. 10]

\begin{tabular}{|c|c|c|c|c|c|c|c|}
\hline \multirow{2}{*}{$\begin{array}{l}\text { Model } \\
\text { segment } \\
\text { number }\end{array}$} & \multicolumn{4}{|c|}{ Precipitation (in inches) } & \multicolumn{3}{|c|}{ Precipitation (in inches) } \\
\hline & $\begin{array}{l}\text { Average } \\
\text { annual }\end{array}$ & $\begin{array}{c}\text { Maximum } \\
\text { annual }\end{array}$ & $\begin{array}{l}\text { Minimum } \\
\text { annual }\end{array}$ & $\begin{array}{c}\text { Maximum } \\
\text { daily }\end{array}$ & $\begin{array}{c}\text { Average } \\
\text { daily }\end{array}$ & $\begin{array}{l}\text { Maximum } \\
\text { monthly }\end{array}$ & $\begin{array}{c}\text { Minimum } \\
\text { monthly }\end{array}$ \\
\hline 42 & 13.1 & 30.1 & 4.1 & 3.8 & 63.3 & 79.7 & 49.9 \\
\hline 43 & 14.1 & 31.4 & 4.6 & 4.1 & 62.9 & 79.3 & 49.7 \\
\hline 46 & 12.3 & 28.4 & 3.6 & 3.6 & 63.4 & 80.4 & 50.1 \\
\hline Average & 20.5 & 47.2 & 6.0 & 5.5 & 58.7 & 77.0 & 43.2 \\
\hline Maximum & 43.3 & 99.3 & 12.4 & 10.8 & 64.5 & 82.1 & 50.4 \\
\hline Minimum & 11.2 & 26.0 & 2.3 & 2.9 & 42.1 & 62.9 & 24.9 \\
\hline
\end{tabular}

\section{Meteorological and Streamflow Data}

Precipitation data were obtained from the National Climatic Data Center (NCDC), San Bernardino County (SBC), and Los Angeles County (LAC) (table 6). Precipitation data were also obtained from the Western Regional Climate Center (WRCC) website from the network of Remote Automated Weather Stations (RAWS) and include hourly measurements of air temperature, dew point temperature (relative humidity), barometric pressure, precipitation, wind speed, and wind direction. Meteorological data were obtained from California Department of Water Resources and University of California at Davis, through the California Irrigation Management Information System (CIMIS). These data included hourly measurements of potential evapotranspiration, precipitation, solar radiation, vapor pressure, air temperature, wind speed and direction and daily measurements of potential evapotranspiration, solar radiation, minimum and maximum air temperature, and average vapor pressure. Precipitation data sources, number of stations and dates for which data were available for each source are shown in table 6. Station locations are shown on figure 1.

Streamflow data were available from USGS streamflow gaging stations for Chino Creek (gage 11073360, Chino Creek at Schaefer Avenue near Chino, California), San Antonio Creek River (gage 11073300, San Antonio Creek at Riverside Drive near Chino, California), West Branch Cucamonga Creek (gage 11073493, West Branch Cucamonga Channel above Ely Percolation Basin at Ontario), and Mill Creek (gage 11073495, Cucamonga Creek near Mira Loma, California) for various time periods (table 6). Daily data were obtained from NWIS, and 15-minute data were obtained directly from the USGS Automated Data Processing System (ADAPS) and processed to produce a mean hourly record. Daily outflow data for San Antonio Dam were available from the Army Corps of Engineers (2005) (table 6).

\section{Surface Properties and Land Use}

Surface properties were estimated from a combination of soils, vegetation, and land-use data. Vegetation is a dominant land cover in some areas of the Chino Basin, particularly in the northern mountainous region. Vegetation type was converted to percent cover (fig. 5) and used in several of the hydrologic parameters, such as shading on snow (SHADE) and interception of rainfall (CEPSC) (table 4). Soils data were available from the State Soil Geographic Database (STATSGO), a state-compiled geospatial database of soil properties that generally are consistent across state boundaries (U.S. Dept. of Agriculture-National Resource Conservation Service, 1994) (table 7; fig. 3B). More detailed information was available from the local and refined database Soil Survey Geographic Database (SSURGO) that is archived by the National Cartography and Geospatial Center and the Natural Resource Conservation Service (Soil Survey Staff, 2007). Soils information, such as particle size, permeability, and depth, are used extensively in the hydrologic parameters for PERLNDS. 


\section{EXPLANATION}

Chino Basin model area

\section{Hydrologic subbasins for} model calibration

Upper Chino Creek

West Branch Cucamonga Creek

San Antonio Canyon

San Antonio Creek

Mill Creek

Modeled streams

USGS stream gage and identifier

San Bernardino County stream gages

- Historical stream gages

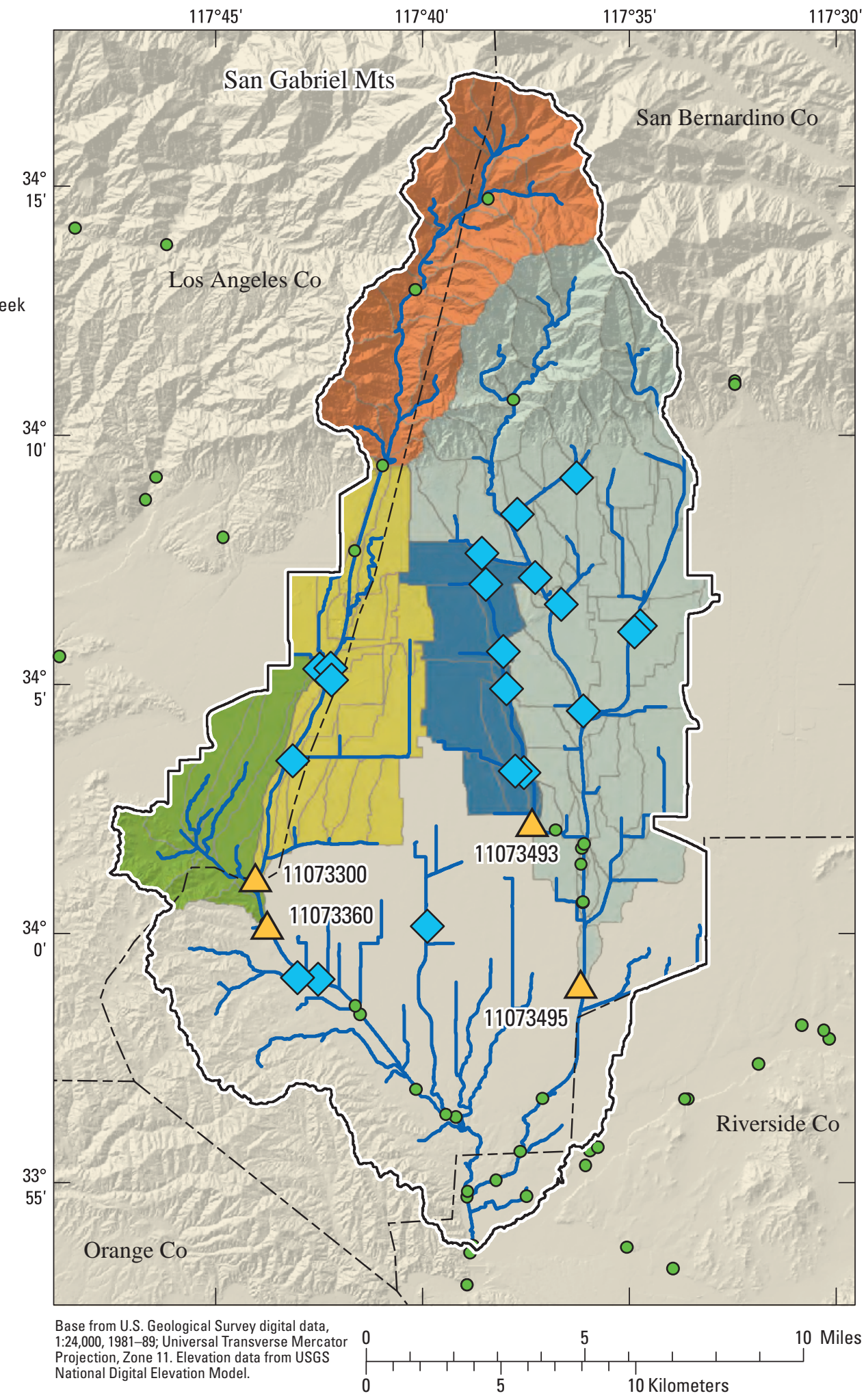

Figure 11. Submodels of basin area upstream of each calibration gage used for hydrologic calibration of the Chino Basin model. 


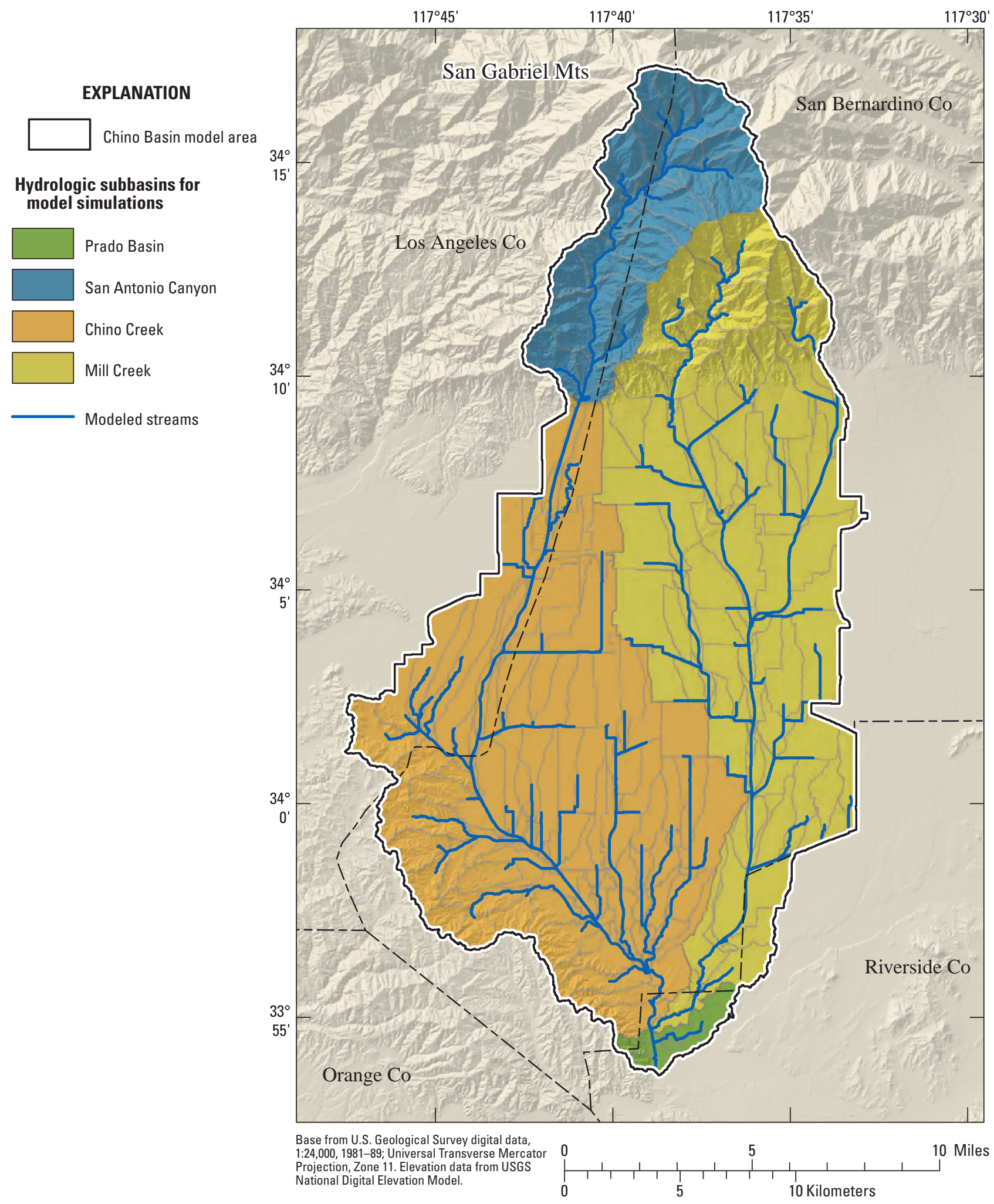

Figure 12. Subbasins used in applications of calibrated model in the Chino Basin. 
Table 6. Meteorological and streamflow data sources, number of stations or station identification, and years with available data used for the Chino Basin model.

[NCDC, National Climatic Data Center; SBC, San Bernardino County; LAC, Los Angeles County; RAWS, Remote Automated Weather Stations; CIMIS, California Irrigation Management Information System]

\begin{tabular}{|c|c|c|c|}
\hline \multicolumn{4}{|c|}{ Meterological data } \\
\hline Parameter & Data source & Number of stations & Available years \\
\hline \multirow[t]{3}{*}{ Precipitation } & NCDC hourly & 49 & $1970-2004$ \\
\hline & SBC & 56 & $1970-2005$ \\
\hline & LAC & 7 & $1970-2005$ \\
\hline Air temperature & NCDC surface airways & 5 & $1970-2004$ \\
\hline Dew-point temperature & CIMIS & 13 & $1980-2005$ \\
\hline Percent cloud cover & CIMIS & 13 & $1980-2005$ \\
\hline Potential evapotranspiration & CIMIS & 13 & $1980-2005$ \\
\hline Wind & CIMIS & 13 & $1980-2005$ \\
\hline \multirow{5}{*}{ Streamflow_daily } & USGS & 11073300 & 1999-2005 \\
\hline & USGS & 11073493 & 1996-2005 \\
\hline & USGS & 11073495 & $1970-2005$ \\
\hline & Army Corps of Engineers & San Antonio reservoir inflows & $1956-2005$ \\
\hline & Army Corps of Engineers & San Antonio Dam outflow & $1956-2005$ \\
\hline \multirow[t]{3}{*}{ Streamflow-15-minute } & USGS & 11073360 & $1988-2005$ \\
\hline & USGS & 11073300 & $1998-2005$ \\
\hline & USGS & 11073493 & $1996-2005$ \\
\hline
\end{tabular}

Table 7. Average State Soil Geographic Database (STATSGO) soil properties for the Chino Basin model.

[ft, foot; in 3in $^{3}$, cubic inch per cubic inch; in/in, inch per inch; in/hr, inch per hour]

\begin{tabular}{cccccccc}
\hline $\begin{array}{c}\text { STATSG0 } \\
\text { map unit } \\
\text { identifier }\end{array}$ & $\begin{array}{c}\text { Area } \\
\text { (acre) }\end{array}$ & $\begin{array}{c}\text { Soil thickness } \\
\text { (ft) }\end{array}$ & $\begin{array}{c}\text { Coarse } \\
\text { fragments } \\
\text { (percent) }\end{array}$ & $\begin{array}{c}\text { Porosity } \\
\text { (in } \mathbf{n}^{\text {3 }} \text { ) }\end{array}$ & $\begin{array}{c}\text { Clay } \\
\text { (percent) }\end{array}$ & $\begin{array}{c}\text { Field capacity } \\
\text { (in/in) }\end{array}$ & $\begin{array}{c}\text { Saturated } \\
\text { hydraulic } \\
\text { conductivity } \\
\text { (in/hr) }\end{array}$ \\
\hline CA676 & 3,005 & 1.5 & 73.0 & 0.42 & 10.69 & 0.26 & 4.88 \\
CA672 & 3,935 & 1.2 & 44.5 & 0.40 & 19.09 & 0.32 & 1.49 \\
CA665 & 1,499 & 4.9 & 36.1 & 0.38 & 9.45 & 0.21 & 8.57 \\
CA671 & 9,515 & 1.4 & 73.5 & 0.43 & 6.94 & 0.22 & 7.84 \\
CA670 & 11,259 & 1.3 & 56.9 & 0.40 & 14.33 & 0.28 & 2.57 \\
CA639 & 78,986 & 4.2 & 22.7 & 0.36 & 7.86 & 0.19 & 8.24 \\
CA645 & 373 & 3.3 & 19.3 & 0.37 & 18.55 & 0.28 & 1.38 \\
CA614 & 10,137 & 4.9 & 20.0 & 0.36 & 12.89 & 0.24 & 3.92 \\
CA642 & 13,398 & 2.3 & 32.8 & 0.42 & 27.52 & 0.36 & 0.65 \\
CA613 & 6,873 & 3.7 & 14.6 & 0.37 & 16.89 & 0.26 & 1.39 \\
\hline
\end{tabular}


GIS data for land use in 2000 in the Chino Basin were available from the Southern California Association of Governments. The land-use coverage identifies 83 possible land-use types, which were combined into 12 general types using general similarities of types that contribute to hydrological routing similarities and density of water-quality contaminants. All urban agricultural land uses, including all animal production land uses, were lumped, with the exception of the dairies, which were a separate land use for this model. Areas indicated as "vacant" were evaluated on the basis of orthophotos from the USGS seamless website (http://seamless.usgs.gov/) to determine if they were natural wildland, wetland, or urban lots. The combined land uses are Shrubs/Grassland, Forest, Barren/Vacant, Mixed Urban, Utilities/Transport, Residential, Mixed Agriculture, Recreation/Open, Commercial/Services, Industrial, Wetlands, Dairies/Feedlots. These general land-use types are used to represent the land uses within each HRU in a subwatershed. The aggregated land-use map is shown in figure 5 .

The degree of imperviousness for any given land use was based on a 2001 map from the National Land Cover Data database (U.S. Geological Survey, 2001). This map was used to define the relative acreages of PERLND and IMPLND for each HRU to assign appropriate hydrologic and transport parameters (fig. 13). The land-use map was evaluated for imperviousness for all the PERLNDS and IMPLNDS and adjusted by a factor related to how effectively the area mapped as impervious facilitated runoff. The initial impervious area was adjusted using aerial photos and orthophotos during calibration to account for hydrologically effective and ineffective areas, and the effective impervious area was adjusted for each land-use type (table 8).

The land-use types for the upstream areas contributing to sampling locations are given in table 9, which illustrates which land use dominates the impervious and pervious landunit types, as well as the dominant land-use or land-unit type contributing to the sampled bacteria concentrations from the different sampling locations.

\section{Model Calibration}

The HSPF model was first calibrated to simulate streamflow, with a particular emphasis on accurately simulating storm runoff. For all calibration and verification model simulations, a three-year model initialization period was used to minimize uncertainty associated with the estimated initial conditions. The initial streamflow calibrations indicated a poor match between simulated and measured flows during low flow conditions. To improve model calibration for the low flows, an assumed nuisance flow component was added to the model by specifying a constant point-source inflow to all reaches receiving surface runoff from urban or agricultural land. The magnitude of the nuisance flow was scaled on the basis of the absolute area of the urban and agricultural land uses within the land area supplying surface runoff to the reach. The scaling was applied consistently to all affected reaches in the Chino Basin model.

The model was calibrated for streamflow by iteratively adjusting hydrologic parameters (table 4) until simulated streamflow closely matched measured streamflow at the five streamflow gaging stations in the study area (four USGS streamflow gages and USACE streamflow data from below San Antonio Dam). The simulation period for calibration was on the basis of available hourly and daily streamflow records from water-year 1990 through water-year 2001, as well as water-year 2004. The calibrated model was verified using hourly and daily streamflow records for water-years 2002-2003 and 2005. In addition, hourly streamflow data for one selected winter (November-February) storm month for each year of the calibration period was used to calibrate storm runoff. Hourly streamflow data for January 2005 were used to verify model simulations of storm flow.

Two general criteria were used for deciding when simulated daily streamflow adequately represented measured daily streamflow: (1) the average difference between simulated and measured daily streamflow during the complete calibration period needed to be less than 20-percent and (2) the average difference between simulated and recorded values of an annual high-flow statistic (daily discharge exceeded 10 percent of the time) also needed to be less than 20 percent for the calibration period. The calibration goals for simulating hourly discharge for high-flow periods were similar to those for simulating daily discharge: (1) during the calibration period, the average difference between simulated and measured hourly discharge that was exceeded 50-percent of the time needed to be less than 20 percent; and (2) during the calibration period, the average difference between the simulated and recorded hourly peak discharge computed as the hourly discharge that was exceeded 10 percent of the time needed to be less than 20 percent. In addition to the numerical goals for calibration and verification, graphical comparisons of simulated and measured discharges were used to judge the effectiveness of the calibrated hydrologic model. The calibration and verification results for hydrologic modeling are described in the following section. 


\section{EXPLANATION}

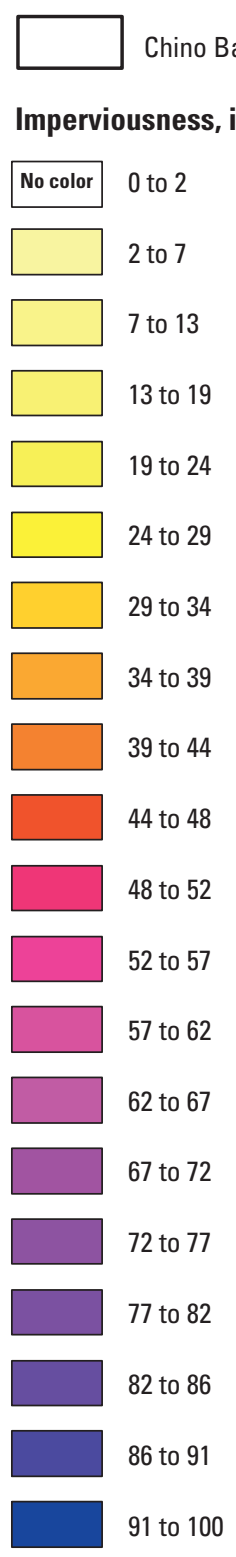

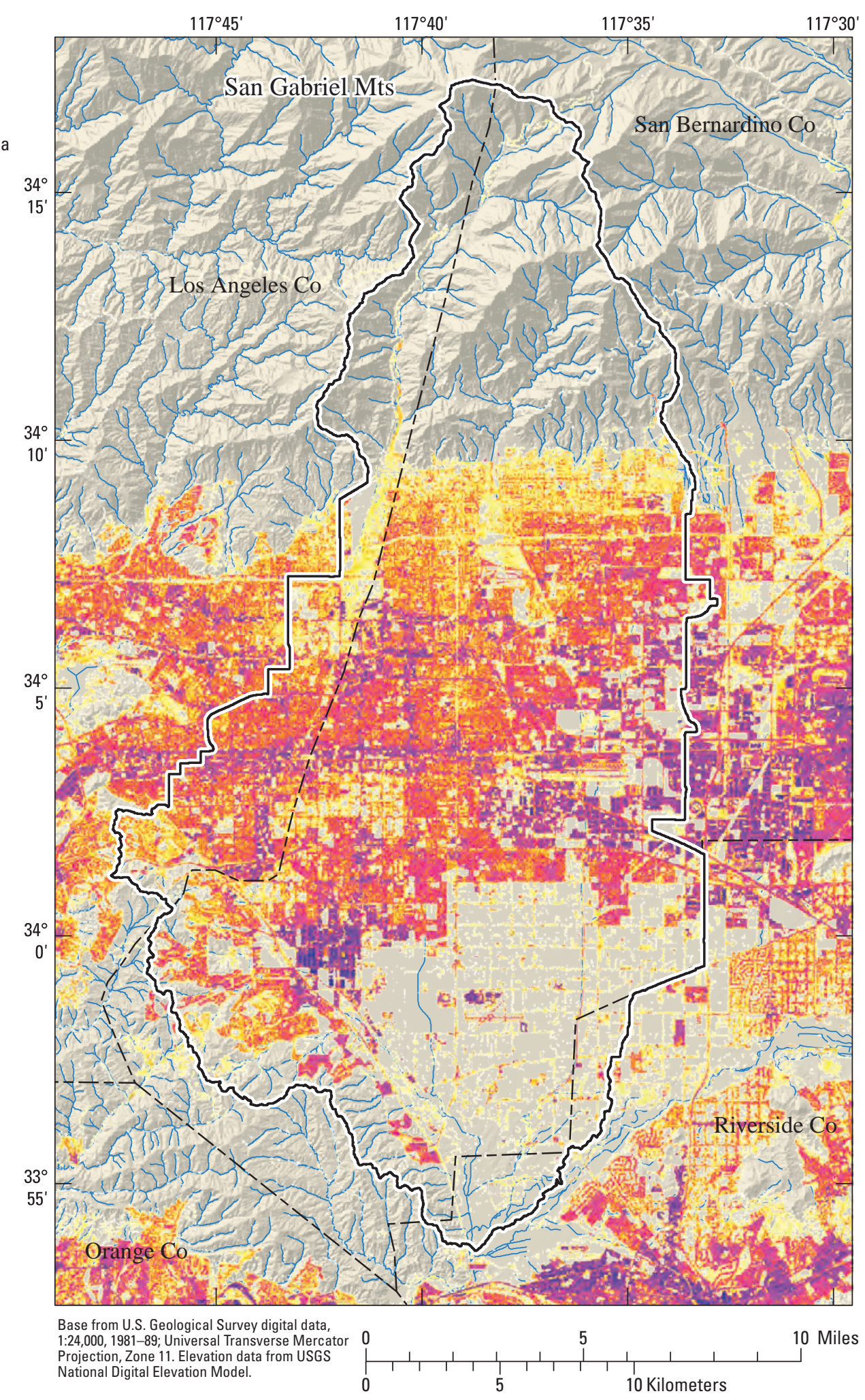

Figure 13. Percentage of imperviousness of the Chino Basin, California. 
Table 8. Initial and adjusted pervious and impervious areas for each land use defined in the Chino Basin model.

[See figure 5 for location. PERLND, pervious land unit; IMPLND, impervious land unit; —, no adjustment]

\begin{tabular}{|c|c|c|c|c|c|c|}
\hline Land use & $\begin{array}{l}\text { Total } \\
\text { area } \\
\text { (acre) }\end{array}$ & $\begin{array}{c}\text { Initial } \\
\text { impervious } \\
\text { area } \\
\text { (percent) }\end{array}$ & $\begin{array}{c}\text { Effective } \\
\text { impervious } \\
\text { area } \\
\text { factor }\end{array}$ & $\begin{array}{l}\text { Adjusted } \\
\text { impervious } \\
\text { area } \\
\text { (percent) }\end{array}$ & $\begin{array}{c}\text { Adjusted } \\
\text { PERLND } \\
\text { area } \\
\text { (acre) }\end{array}$ & $\begin{array}{c}\text { Adjusted } \\
\text { IMPLND } \\
\text { area } \\
\text { (acre) }\end{array}$ \\
\hline Commercial and services & 8,922 & 45.0 & 0.8 & 36.0 & 5,708 & 3,214 \\
\hline Forest & 11,693 & 0.3 & 0.0 & 0.0 & 11,693 & - \\
\hline Industrial & 9,404 & 52.3 & 0.9 & 47.1 & 4,978 & 4,427 \\
\hline Intensive livestock (dairies) & 6,891 & 4.1 & 0.5 & 2.1 & 6,749 & 142 \\
\hline Mixed agriculture & 12,205 & 4.8 & 0.5 & 2.4 & 11,912 & 293 \\
\hline Mixed urban & 6,692 & 21.4 & 0.7 & 15.0 & 5,689 & 1,003 \\
\hline Wetland or water & 777 & 3.9 & 0.0 & 0.0 & 777 & - \\
\hline Total & 138,978 & & & & 117,369 & 21,609 \\
\hline
\end{tabular}

On the basis of available measured bacteria data of $<2 \mathrm{cfu} / 100 \mathrm{~mL}$ from the six permitted point sources (Carbon Canyon POTW discharge to Chino Creek, RP-1 discharge to Cucamonga channel, RP-1 discharge to Prado Park Lake, RP-2 discharge to Chino Creek, RP-5 discharge to Chino Creek, and Orange County water transfers to San Antonio Channel below San Antonio Dam), which is insignificant in comparison with other point source loadings, the permitted point sources were represented in the model as pristine (bacteria-free) inflows. Monthly and daily discharge data for wastewater effluent were obtained from the inland Empire Utility Agency and Wildermuth Environmental, Inc. (Wildermuth Environmental, Inc., 2003). Monthly and daily discharge data for the Orange County water transfers were obtained from the Orange County Water District and Wildermuth Environmental, Inc. (Gwen Sharp, Orange County Water District, Fountain Valley, California, Wildermuth Environmental, Inc., unpub. data, 2003). The monthly and daily time-series data were converted to hourly time-series data that assumed uniform daily or monthly discharge rates, and the hourly data were incorporated into the model as point sources.

Bacteria were measured at six permitted point sources: Carbon Canyon POTW discharge to Chino Creek, RP-1 discharge to Cucamonga channel, RP-1 discharge to Prado Park Lake, RP-2 discharge to Chino Creek, RP-5 discharge to Chino Creek, and Orange County water transfers to San Antonio Channel below San Antonio Dam. The available data show that bacteria concentrations at these point sources were $<2 \mathrm{cfu} / 100 \mathrm{~mL}$, which was insignificant compared with other point source loadings and therefore the inflows at these point sources were represented in the model as being pristine (bacteria-free).

Daily and hourly mean discharge data were available for San Antonio Dam outflow (R.M. Kuboshige, U.S. Army Corps of Engineers, Los Angeles, California, unpub. data, 2006). These data were combined to develop an hourly time series representing the surface-water inflows from the San Antonio Canyon subbasin to the Chino Creek subbasin. The hourly time-series was incorporated into the model as a pristine pointsource discharge at the headwaters of San Antonio Creek (at San Antonio Dam outflow) in the Chino Creek subbasin. The pristine point-source discharge was used only for calibrating the model to streamflow. Transport-model calibration, as well as model applications, incorporated the simulated outflow from San Antonio Dam, and included both simulated hourly discharge and simulated bacteria concentration rather than the measured records used for flow calibration and verification. 
Table 9. Land-use acreages for impervious and pervious land unit types for upstream subbasin areas contributing to sampling locations in the Chino Basin, California.

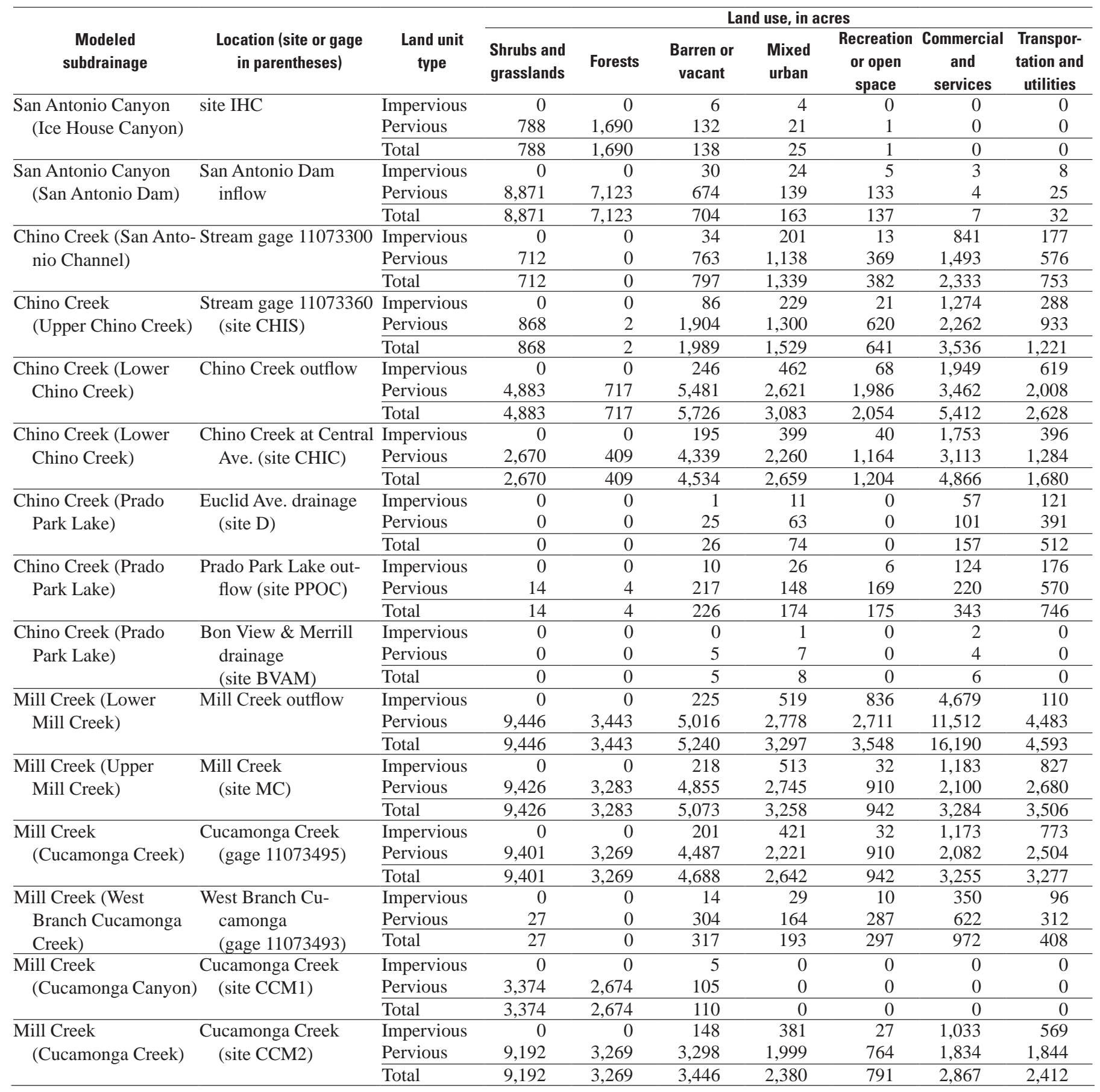


Table 9. Land-use acreages for impervious and pervious land unit types for upstream subbasin areas contributing to sampling locations in the Chino Basin, California.-Continued

\begin{tabular}{|c|c|c|c|c|c|c|c|c|}
\hline \multirow[b]{2}{*}{ Modeled subdrainage } & \multirow[b]{2}{*}{$\begin{array}{l}\text { Location (site or gage } \\
\text { in parentheses) }\end{array}$} & \multirow[b]{2}{*}{ Land unit type } & \multicolumn{5}{|c|}{ Land use, in acres } & \multirow[b]{2}{*}{$\begin{array}{c}\text { Total, in } \\
\text { acres }\end{array}$} \\
\hline & & & Residential & $\begin{array}{c}\text { Mixed } \\
\text { agriculture }\end{array}$ & Industrial & $\begin{array}{l}\text { Water and } \\
\text { wetlands }\end{array}$ & $\begin{array}{l}\text { Intensive } \\
\text { livestock }\end{array}$ & \\
\hline \multirow{3}{*}{$\begin{array}{l}\text { San Antonio Canyon } \\
\text { (Ice House Canyon) }\end{array}$} & \multirow[t]{3}{*}{ site IHC } & Impervious & 0 & 0 & 0 & 0 & 0 & 10 \\
\hline & & Pervious & 0 & 0 & 0 & 0 & 0 & 2,631 \\
\hline & & Total & 0 & 0 & 0 & 0 & 0 & 2,641 \\
\hline \multirow{3}{*}{$\begin{array}{l}\text { San Antonio Canyon } \\
\text { (San Antonio Dam) }\end{array}$} & \multirow{3}{*}{$\begin{array}{l}\text { San Antonio Dam } \\
\text { inflow }\end{array}$} & Impervious & 20 & 0 & 55 & 0 & 0 & 145 \\
\hline & & Pervious & 50 & 2 & 62 & 0 & 0 & 17,083 \\
\hline & & Total & 70 & 2 & 117 & 0 & 0 & 17,228 \\
\hline \multirow{3}{*}{$\begin{array}{l}\text { Chino Creek (San Anto- } \\
\text { nio Channel) }\end{array}$} & \multirow{3}{*}{$\begin{array}{r}\text { Stream gage } \\
11073300\end{array}$} & Impervious & 1,707 & 13 & 959 & 0 & 0 & 3,946 \\
\hline & & Pervious & 4,201 & 536 & 1,078 & 0 & 15 & 10,881 \\
\hline & & Total & 5,909 & 549 & 2,037 & 0 & 16 & 14,827 \\
\hline \multirow{3}{*}{$\begin{array}{l}\text { Chino Creek (Upper } \\
\text { Chino Creek) }\end{array}$} & \multirow{3}{*}{$\begin{array}{l}\text { Stream gage } \\
11073360 \\
\text { (site CHIS) }\end{array}$} & Impervious & 2,974 & 15 & 1,219 & 0 & 0 & 6,104 \\
\hline & & Pervious & 7,317 & 592 & 1,371 & 0 & 15 & 17,184 \\
\hline & & Total & 10,290 & 606 & 2,589 & 0 & 16 & 23,288 \\
\hline \multirow{3}{*}{$\begin{array}{l}\text { Chino Creek (Lower } \\
\text { Chino Creek) }\end{array}$} & \multirow[t]{3}{*}{ Chino Creek outflow } & Impervious & 5,294 & 161 & 2,099 & 0 & 56 & 10,955 \\
\hline & & Pervious & 13,027 & 6,559 & 2,360 & 167 & 2,694 & 45,965 \\
\hline & & Total & 18,321 & 6,720 & 4,459 & 167 & 2,750 & 56,919 \\
\hline \multirow{3}{*}{$\begin{array}{l}\text { Chino Creek (Lower } \\
\text { Chino Creek) }\end{array}$} & \multirow{3}{*}{$\begin{array}{l}\text { Chino Creek at Cen- } \\
\text { tral Ave. } \\
\text { (site CHIC) }\end{array}$} & Impervious & 4,526 & 55 & 1,996 & 0 & 7 & 9,366 \\
\hline & & Pervious & 11,136 & 2,228 & 2,245 & 19 & 340 & 31,206 \\
\hline & & Total & 15,662 & 2,282 & 4,241 & 19 & 347 & 40,572 \\
\hline \multirow{3}{*}{$\begin{array}{l}\text { Chino Creek (Prado } \\
\text { Park Lake) }\end{array}$} & \multirow{3}{*}{$\begin{array}{l}\text { Euclid Ave. drainage } \\
\quad \text { (site D) }\end{array}$} & Impervious & 144 & 31 & 14 & 0 & 18 & 394 \\
\hline & & Pervious & 353 & 1,239 & 15 & 0 & 838 & 3,025 \\
\hline & & Total & 497 & 1,270 & 29 & 0 & 856 & 3,420 \\
\hline \multirow{3}{*}{$\begin{array}{l}\text { Chino Creek (Prado } \\
\text { Park Lake) }\end{array}$} & \multirow{3}{*}{$\begin{array}{l}\text { Prado Park Lake out- } \\
\text { flow (site PPOC) }\end{array}$} & Impervious & 345 & 66 & 49 & 0 & 43 & 844 \\
\hline & & Pervious & 850 & 2,680 & 55 & 55 & 2,072 & 7,051 \\
\hline & & Total & 1,195 & 2,746 & 104 & 55 & 2,115 & 7,896 \\
\hline Chino Creek (Prado & Bon View \& Merrill & Impervious & 0 & 6 & 0 & 0 & 7 & 17 \\
\hline Park Lake) & drainage (site & Pervious & 1 & 255 & 0 & 0 & 350 & 620 \\
\hline & BVAM) & Total & 1 & 261 & 0 & 0 & 357 & 638 \\
\hline Mill Creek (Lower & Mill Creek outflow & Impervious & 37 & 1,189 & 2,112 & 0 & 73 & 9,780 \\
\hline Mill Creek) & & Pervious & 1,048 & 2,111 & 2,375 & 198 & 3,485 & 48,605 \\
\hline & & Total & 1,085 & 3,300 & 4,486 & 198 & 3,558 & 58,385 \\
\hline Mill Creek (Upper & Mill Creek (site MC) & Impervious & 4,679 & 86 & 2,106 & 0 & 60 & 9,703 \\
\hline Mill Creek) & & Pervious & 11,512 & 3,507 & 2,368 & 26 & 2,820 & 46,231 \\
\hline & & Total & 16,190 & 3,593 & 4,475 & 26 & 2,879 & 55,934 \\
\hline Mill Creek (Cucamonga & Cucamonga Creek & Impervious & 4,660 & 22 & 1,987 & 0 & 6 & 9,275 \\
\hline Creek) & (gage 11073495) & Pervious & 11,465 & 914 & 2,235 & 15 & 267 & 39,769 \\
\hline & & Total & 16,125 & 937 & 4,222 & 15 & 273 & 49,044 \\
\hline Mill Creek (West & West Branch Cu- & Impervious & 3 & 1,394 & 346 & 0 & 0 & 2,240 \\
\hline Branch Cucamonga & camonga & Pervious & 116 & 3,429 & 389 & 0 & 0 & 5,648 \\
\hline & & Total & 119 & 4,822 & 734 & 0 & 0 & 7.888 \\
\hline Mill Creek (Cucamonga & Cucamonga Creek & Impervious & 0 & 0 & 0 & 0 & 0 & 5 \\
\hline Canyon) & (site CCM1) & Pervious & 0 & 0 & 0 & 0 & 0 & 6,153 \\
\hline & & Total & 0 & 0 & 0 & 0 & 0 & 6,158 \\
\hline Mill Creek (Cucamonga & Cucamonga Creek & Impervious & 4,264 & 10 & 1,368 & 0 & 0 & 7,800 \\
\hline Creek) & (site CCM2) & Pervious & 10,492 & 387 & 1,538 & 8 & 0 & 34,624 \\
\hline & & Total & 14,757 & 397 & 2,906 & 8 & 0 & 42,424 \\
\hline
\end{tabular}


After the model was calibrated and verified for simulation of streamflow, it was calibrated for simulation of indicator bacteria concentrations. Initial estimates of the total amount of bacteria deposited by each of the dominant sources of fecal coliform bacteria were based on literature values taken from the BASINS software default parameters that are based on a case study by the U.S. Environmental Protection Agency in Cottonwood Creek, Idaho (U.S. Environmental Protection Agency, 2000; table 4). Parameter estimates from other HSPF modeling studies conducted in the region (Ackerman and Weisberg, 2003; Guay, 2002; U.S. Environmental Protection Agency, 2000; table 4), were used for comparison with the calibrated parameters developed for this study and to help develop initial estimates for land uses not represented by the storm sampling. Few data were available to calculate specific deposition or accumulation rates for indicator bacteria. Landsurface processes were represented by parameters shown in table 4: ACCUM, SQOLIM, SQO, and WSQOP, which were assigned according to land use; REMQOP, a constant die-off rate described in the model description section; IQO and AQO (fig. 9) were assigned to land surfaces in San Antonio Canyon to represent interflow and baseflow transport, respectively. An assumed bacteria concentration for nuisance flow was represented as a uniform value proportional to the absolute area of the urban and agricultural land uses connected to each reach (and thus supplying overland flow to that reach). The proportionality constants were then adjusted such that simulated concentrations matched observed data.

The bacteria transport model was first calibrated to the storm samples collected during water-year 2004 (storms of $11 / 11 / 2003,2 / 2 / 2004$, and 2/22/2004) that provided information on loadings for targeted land-use areas. These usually consisted of runoff from small areas (or catchments; a few acres to several tens of acres) that represented specific land uses. These small catchments were included in the model as separate RCHRES segments (each sample site was included as a RCHRES). Stormflows and bacteria concentrations were simulated for these RCHRES segments and compared with concentrations measured in the field. The primary parameters that were iteratively changed to match simulated concentrations with measured concentrations were the 7 parameters listed in the PQUAL module section of table 4. Final transport model calibration incorporated all available bacteria data for the Chino Basin, including the storm- and land-use-targeted samples collected as part of this study and the supplemental data available from previous and ongoing studies of pathogen indicator bacteria in the Chino Basin.

\section{Results from the Streamflow and the Fecal Coliform Models}

\section{Streamflow-Model Calibration and Verification Results}

Streamflow-model calibration, during which model parameters were changed to improve the predictive capability of the model, was based on the comparison of simulated and measured hourly and daily streamflow at the four USGS gaged sites and on the comparison of simulated and measured daily streamflow at San Antonio Dam. All calibrations were for WY1990-WY2001 and WY2004. The streamflow model was verified to illustrate its predictive capability for WY2002-WY2003 and WY2005 using the calibrated model and comparisons of simulated and measured streamflow at the sites used for model calibration. Records for a period which had variations in climate but no major changes in land use were chosen to calibrate the model. Water-year 2004 was used for calibration, but not verification, to reduce uncertainty of simulated streamflow for the storms sampled as part of this study. Land use was represented as constant over the model period on the basis of maps available in 2000.

Examples of simulated and measured storm flows for February 2004 for the gage locations on Chino Creek (gage 11073360) and San Antonio Creek (gage 11073300) (fig. 2) shown in figure 14 illustrate good matches in peak flows for both locations for the series of five runoff events. Measured and simulated streamflow values for the 1, 10, 25, and 50 percent highest flows and the 1, 10, 25, and 50 percent lowest flows were compared for the entire calibration period. These results of the comparisons and the regression results are given in table 10 for mean hourly streamflow at all USGS sites and for daily inflow to San Antonio Dam; the results include comparisons for average flows during winter and summer. Calibration and verification results, based on graphical comparison of simulated and measured hourly and daily flow-duration curves, are shown for the USGS gages and for measured daily inflow to San Antonio Dam in figure 15. 
$\boldsymbol{A}$
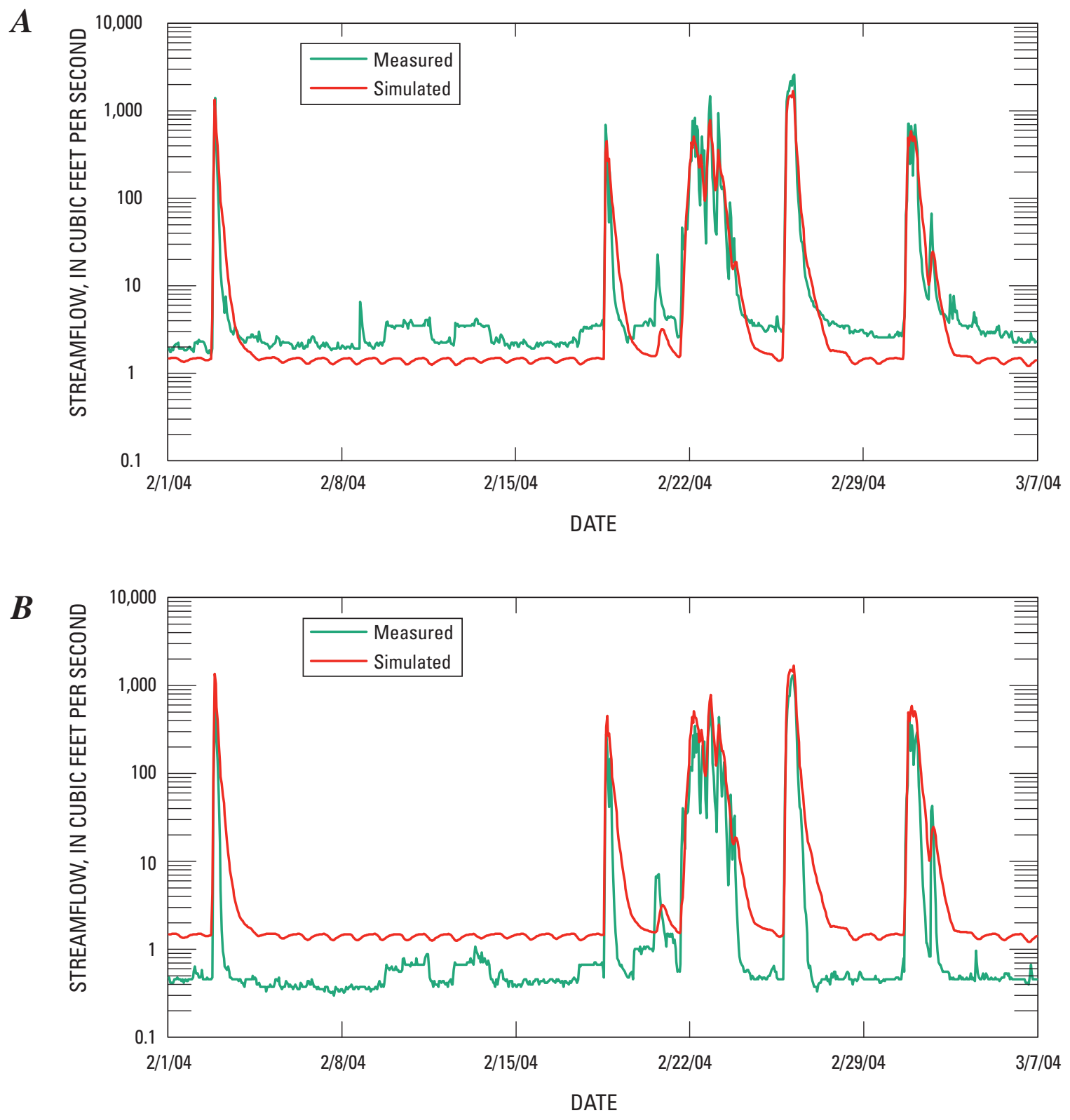

Figure 14. Simulated and measured hourly streamflow for February 2004 for the calibration period for $A$, Chino Creek gage 11073360 and $B$, San Antonio Creek gage 11073300 in the Chino Basin, California.

The model was calibrated by changing parameters consistently over all basins, rather than changing parameters within each subbasin. Having a consistently calibrated parameter set for all gaged subbasins improved the overall robustness of the model when applied to the ungaged areas of the Chino Basin, which included a substantial area in the southern part of the basin. This calibration approach required compromises between matching high flows in some subbasins and low flows in other subbasins. In addition, as there were no data to support variable nuisance flows in the different subbasins, a uniform nuisance inflow rate was added to all affected reaches and was scaled uniformly using the absolute area of the combined urban and agricultural land uses contributing runoff to the affected reach. The scaling factor was adjusted during calibration to better match the lower flows. The uniform scaling caused the similarity between simulated lower flows and measured lower flows in some basins to decrease. This is illustrated for both Chino Creek, for which nuisance flows were underestimated, and San Antonio Creek, for which nuisance flows were overestimated (fig. 14). 


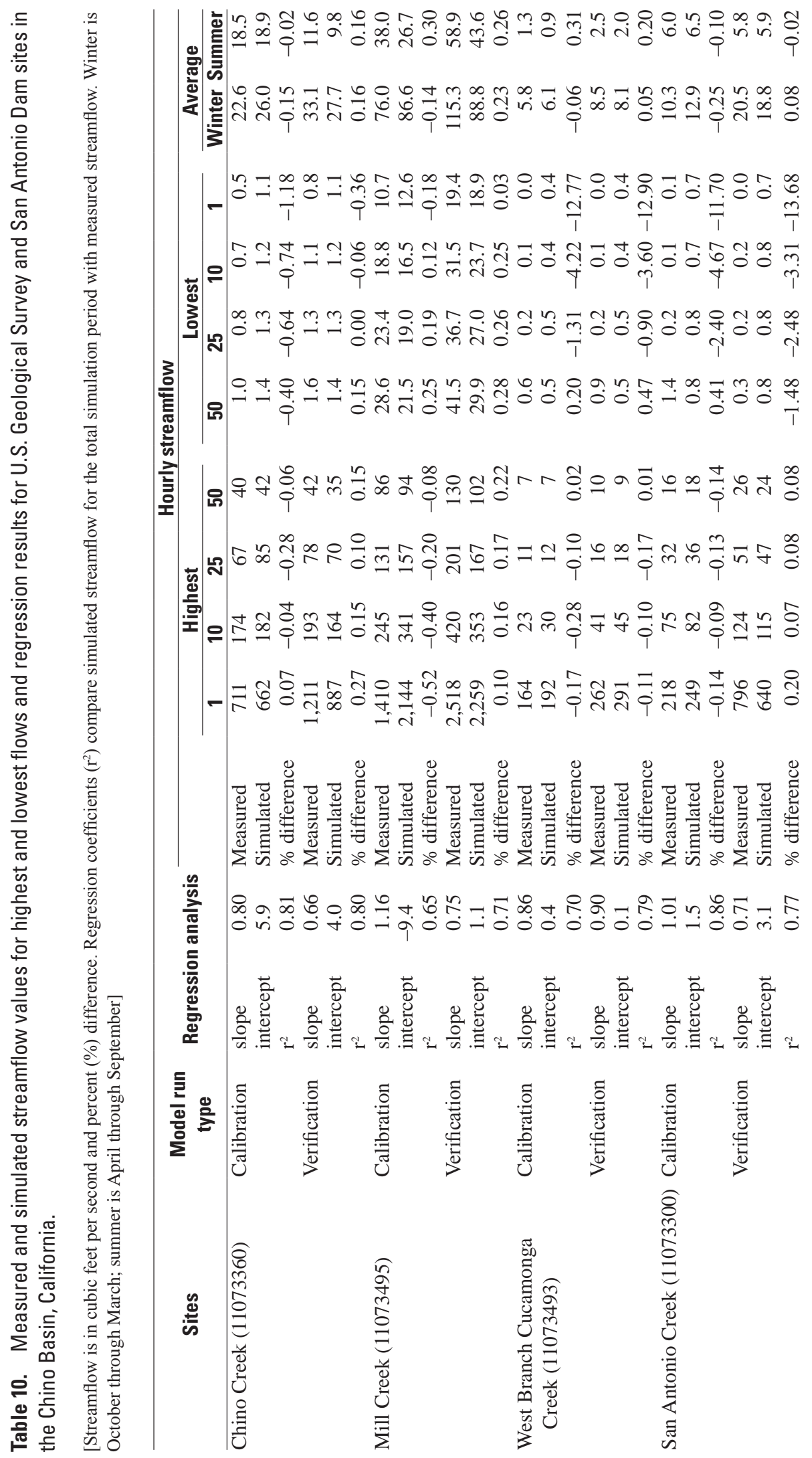




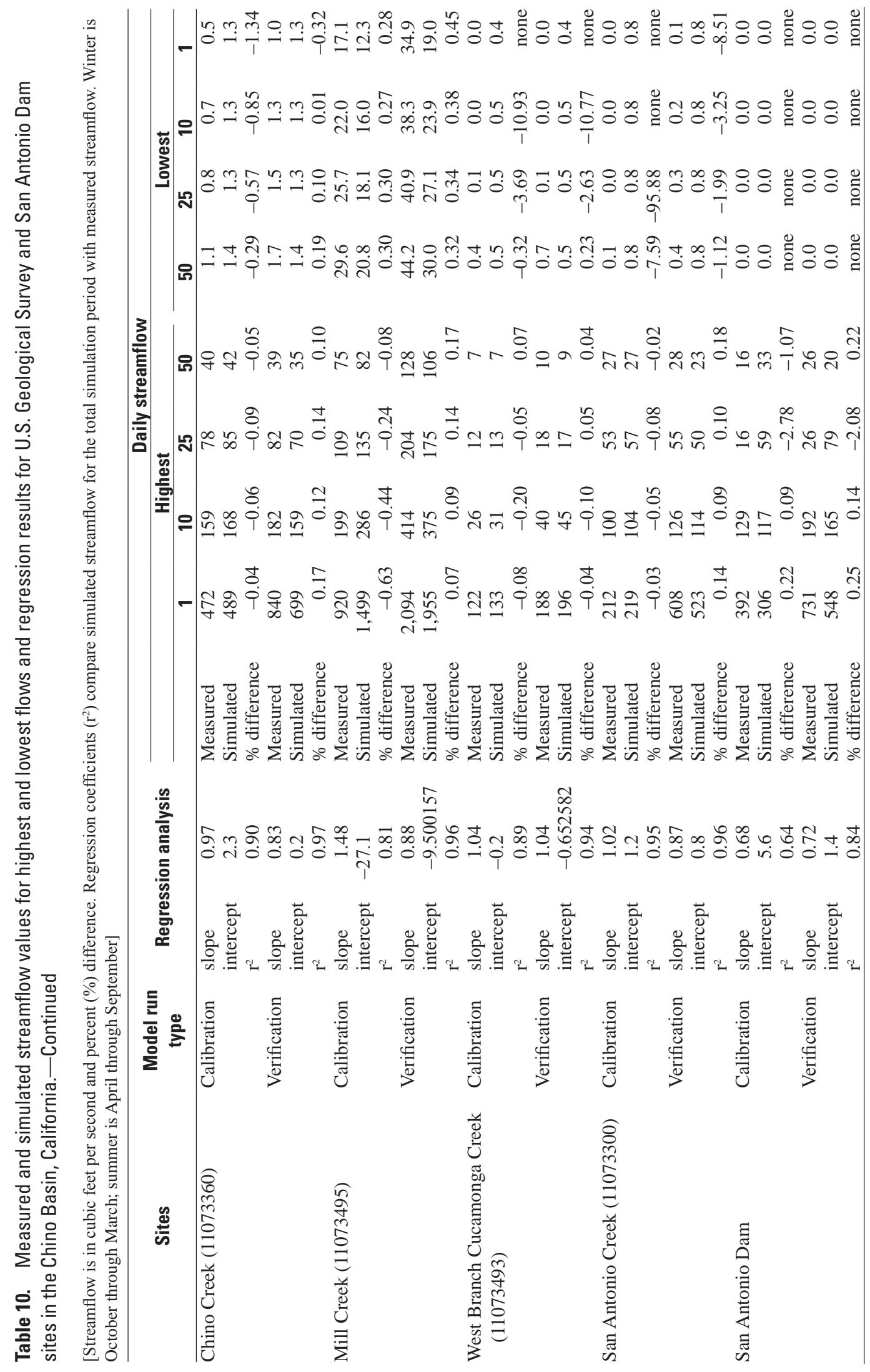



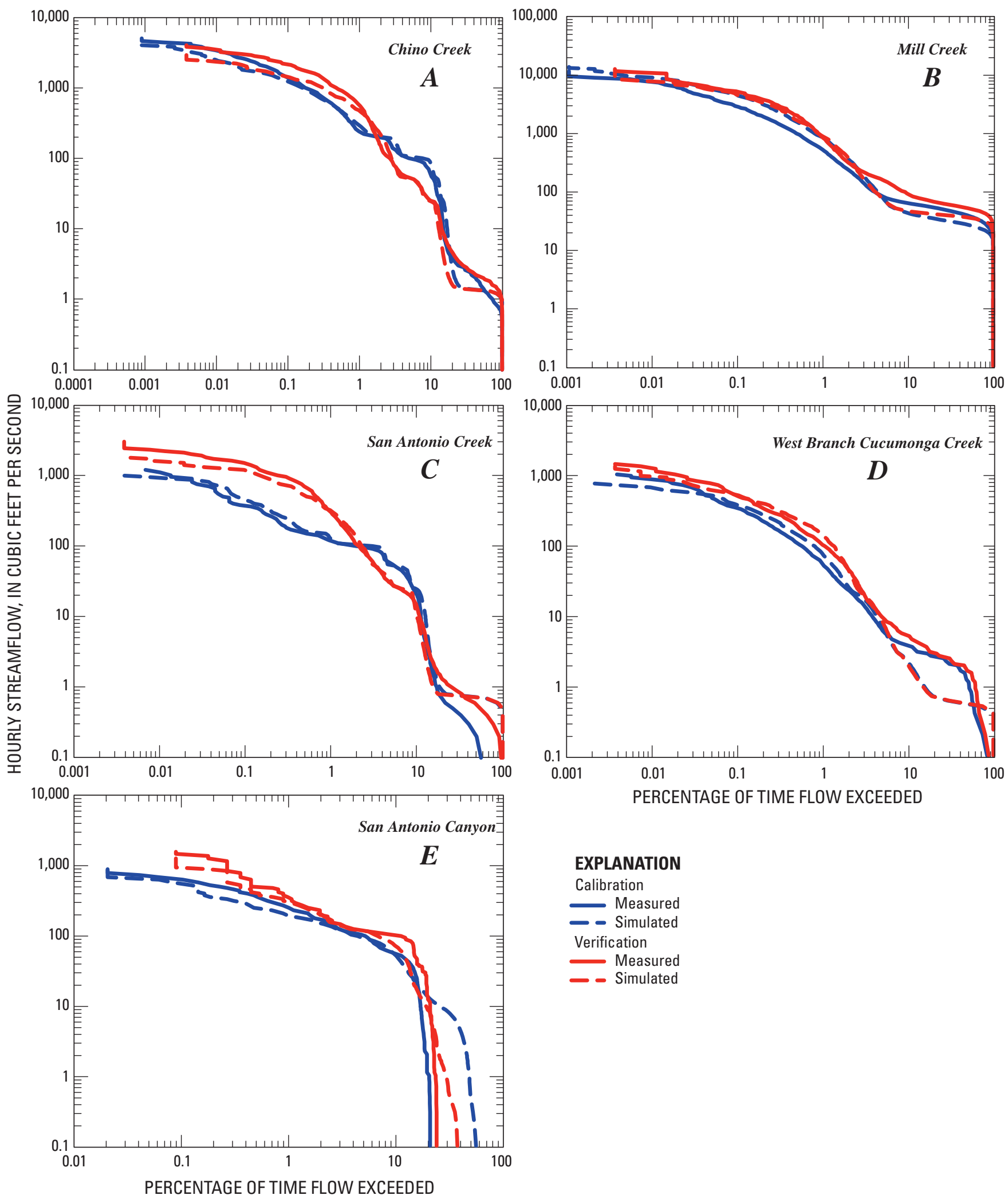

\section{EXPLANATION}

Calibration

Measured

- Simulated

Verification

Measured

- Simulated

Figure 15. Flow duration curves for simulated and measured streamflow for calibration and verification periods for $A$, Chino Creek, $B$, Mill Creek, C, San Antonio Creek, D, West Branch Cucamonga Creek, and E, San Antonio Canyon reach in the Chino Basin, California. 
The lack of specific data for flow diversions caused estimations of low flows to be particularly uncertain in some locations, especially in San Antonio Canyon (fig. 15E). For the urbanized subbasins upstream of the four USGS gages, specific data for transfers to recharge spreading basins, and minor inflows from local point sources, were not readily available and were not incorporated into this study. More generalized data, such as estimated annual recharge at several of the main spreading basins (Wildermuth Environmental, Inc., 2002), were incorporated into model development and calibration.

Verification results illustrate that the model generally agreed with most measured streamflows. However, the simulated streamflows for WY2005, a year characterized by large storm flows, did not agree with the measured streamflows. These flows were greater than those used for calibration, which suggests that the model was extrapolated beyond the range of streamflows used for calibration. This resulted in differences between measured and simulated results for verification periods for Chino Creek and San Antonio Creek that were somewhat high (table 10). Another condition not incorporated into the model was the increase in imperviousness during the study period, including the addition of concrete-lined channels, all of which contributed to a general underestimation of peaks, particularly in Mill Creek (table 10). In general, the comparison of simulated streamflow with measured streamflow met the criteria for acceptable calibration, with the exception of the highest flows in Mill Creek, which simulation results overestimated. Applying the calibrated model to the verification period was quite successful and met the criteria in all cases. Specific details regarding the calibration of each basin follow.

\section{Chino Creek Subbasin}

The model for the Chino Creek subbasin was calibrated and verified using measured streamflow data from USGS gage 11073360 for both daily and hourly time steps. This subbasin, which is significantly influenced by the San Antonio Dam releases and Orange County water transfers, provides a good representation of urban runoff that includes variable nuisance flow. There was very little area upstream of gage 11073360 that is agricultural or has dairies; therefore, their input was insignificant. The gage is the main flow calibration point for Chino Creek subbasin, which includes San Antonio Creek and eastern Chino Creek. The location of the streamgage coincides with the RWQCB sampling site identified as site CHIS in this report.

A comparison of simulated and measured hourly flow duration curves indicating the percentage of time hourly streamflows were exceeded for during the calibration and verification periods is shown in figure $15 A$ and illustrates a slight under-simulation of peaks and a slight under-simulation of very low flows. Regression results comparing simulated and measured hourly streamflow indicate $\mathrm{r}^{2}$ values were about 0.80 for both calibration and verification periods (table 10).

\section{Mill Creek Subbasin}

The Mill Creek subbasin is represented by USGS gage 11073495. This watershed provides a good representation of an integrated response to urban runoff with some natural runoff and a minor amount of agricultural runoff. There is a high baseflow caused by large releases of effluent at RP-1 and a significant nuisance flow.

A comparison of hourly simulated and measured streamflow related to the percentage of time the flow was exceeded is shown in Figure $15 B$ and illustrates peak flows higher than those in all other subbasins. The $r^{2}$ values are lower than those for other subbasins because this subbasin is larger and more heterogeneous spatially (table 10). More land in the Mill Creek subbasin than in other areas was affected by changes in land use (primarily residential and commercial development) and by channel engineering (development of new retention basins, emplacement of concrete lined channels).

\section{San Antonio Creek Subbasin}

San Antonio Channel drains the outflow from San Antonio Dam and the drainage area between the dam and USGS gage 11073300 that is located just upstream of the confluence of San Antonio Creek and Chino Creek. The area between the gage and the dam comprises the San Antonio Creek subbasin, which represents urban runoff, with significant influence from San Antonio Dam and the Orange County water transfers just downstream of the dam. There is also variable nuisance flow in this subbasin. Calibrating this gage is important for checking the upstream response to the main calibration gage at Chino Creek and for representing recharge in spreading and retention basins (a significant part of the outflow from San Antonio Dam as well as the Orange County water transfer is recharged upstream of the San Antonio Channel stream gage).

Simulated streamflows at the San Antonio Channel gage compare well with measured streamflow for both high and low flows (fig. 15C) for both hourly and daily timesteps (table 10), and $\mathrm{r}^{2}$ values are high (table 10). The simulated hourly flows are slightly less than those measured at the highest peak flows, and slightly lower than those measured at the very lowest flows.

\section{West Branch Cucamonga Creek Subbasin}

The West Branch Cucamonga Creek and USGS gage 11073493 is upstream of and flows into Mill Creek. This subbasin is smaller than Chino Creek and Mill Creek watersheds and provides a good representation of urban runoff with variable nuisance flow and no additional inflows from water diversions or wastewater effluent. 
Simulated flows at the West Branch Cucamonga Creek gage were generally slightly higher than the highest measured flows during the calibration period, whereas simulated low flows were generally lower (table 10; fig. 15D). The regression analysis indicates better correlations between daily simulated and measured values than for hourly values (table 10). Simulated nuisance flows underestimate measured flows for both calibration and verification periods (fig. 15D).

\section{San Antonio Dam inflow}

San Antonio Creek, which drains San Antonio Canyon, provides the surface water inflow into the storage basin behind San Antonio Dam. The USACE has maintained a record of daily inflows that was used to calibrate the model. The hydrology of this mountainous subbasin is strongly controlled by the formation and melting of a winter snowpack. Nuisance flows and urban runoff are generally nonexistent, but some baseflow in San Antonio Creek may occur in response to ground-water discharge from springs or as delayed release from streambed storage. Baseflow in the upper sections of San Antonio Creek may not reach the San Antonio Dam storage basin because of flow diversions and channel losses (recharge).

Calibration results using the daily streamflow record representing the inflow to San Antonio Dam indicate a reasonable fit between simulated and measured streamflow for medium to high streamflow magnitudes (table 10), with a poor fit for flows less than $10 \mathrm{ft}^{3} / \mathrm{s}$ (fig. 15E). Simulating low flows was particularly difficult because channel losses and diversions upstream of the dam were not known exactly.

\section{Transport Model Calibration and Verification Results}

Transport simulations were done for total coliforms, fecal coliforms, E. coli, and enterococci, but for simplicity, most results are represented by results from the transport of fecal coliforms. Comparisons of simulated and measured fecal coliform concentrations were done on results obtained using the advective (dissolved constituent) transport parameters developed for previous studies in nearby coastal watersheds (Stein and others, 2003). These parameters were used successfully in the San Jacinto basin water-quality modeling study (Tetra Tech Inc., 2003), and were applied in this study as a reference for a set of regionally calibrated transport parameters. They were also used to help develop initial estimates of parameter values for land uses (such as natural land uses) not represented explicitly in the storm-water samples collected for the study. The purpose of the comparison was to help evaluate conditions in the Chino Basin study area relative to average conditions in nearby watersheds, and to provide a reference to a parameter set not calibrated specifically to the Chino Basin bacteria data. The regional parameters do not necessarily define a final set of calibrated parameters, and are referred to in this study as the uncalibrated parameter set.
The average calibrated HSPF transport parameters defining non-point source loading for bacteria, ACCUM and SQOLIM, are shown in table 11 for the 12 land-use categories for both IMPLNDs and PERLNDs. The calibrated bacteria loading parameters (ACCUM and SQOLIM) for the urban and agricultural land uses were generally higher than the initial uncalibrated parameter values that were based on literature values and examples from other studies. Bacteria loading rates and limits calibrated for PERLNDs were higher (by a factor of 5) compared to IMPLND loading rates and limits for a given land use. The washoff limits for all PERLND land uses were higher than the limits for corresponding IMPLND land uses, representing an increase in surface roughness for the pervious land areas. The calibrated bacteria loading rates were much higher for urban land than for grasslands or forests, which is consistent with other studies. Highest loadings were for intensive livestock land-use for both impervious and pervious land units, and the second highest loadings were for mixed agriculture.

\section{Analyses of Storm-Targeted Samples for Storms in Water-Year 2004}

The transport model was calibrated for land-use-specific storm sampling sites (water-year 2004 storm samples) by qualitatively comparing simulated and measured hourly bacteria concentrations at the specific location of sample collection, included in the model as a separate reach (RCHRES) for each sampling site. Trial and error adjustments of transport parameters were used to optimize the fit of model simulations to measured data. In addition to bacteria concentrations, the field data included measurements of stage (water-surface elevation), and these were used as a relative measure of stream flow. The upstream catchments for most of the specific land-use sampling sites were generally small (from 3 to approximately 100 acres). Stream flow and bacteria transport at these sites were simulated using a single land-use segment (apportioned into impervious and pervious areas) connected to a single reach segment representing the flow conduit sampled in the field. With the exception of the Mill Creek integrated sample site (site MC), these flow conduits were street gutters, parking lot drains, and small drainage features or storm drains. Although model parameters defining these small catchment areas and flow conduits were adjusted to provide an improved fit between simulated and measured stage, there were no flow measurements available for model calibration. As part of the model calibration process, simulated hourly bacteria concentrations were excluded from the analysis if the hourly simulated streamflow was less than $0.0005 \mathrm{ft}^{3} / \mathrm{s}$. The screening was done to avoid potential problems with model simulations that tend to occur in connection with extremely low flows. For example, concentrations for dry reaches are undefined, and thus zero-discharge conditions were excluded from the analysis. 
Table 11. Values for transport parameters SOO, ACCUM, SOOLIM, and WSOOP for 12 land uses and impervious and pervious land units in the Chino Basin, California.

[SQO (initial loading on land), ACCUM (daily loading on land), and SQOLIM (die-off on land in between runoff events) are given in organisms per acre; WSQOP (rainfall needed to remove 90 percent of accumulated pollutant on land) is in inches per hour]

\begin{tabular}{|c|c|c|c|c|}
\hline \multirow{2}{*}{ Land use } & \multicolumn{4}{|c|}{ Transport parameters } \\
\hline & SoO & ACCUM & SOOLIM & WSOOP \\
\hline \multicolumn{5}{|c|}{ Impervious land units } \\
\hline Commercial and services & $5.00 \mathrm{E}+09$ & $5.00 \mathrm{E}+09$ & $9.00 \mathrm{E}+09$ & $9.00 \mathrm{E}-02$ \\
\hline Forest & $1.30 \mathrm{E}+07$ & $1.30 \mathrm{E}+07$ & $2.30 \mathrm{E}+07$ & 5.10E-01 \\
\hline Intensive livestock & $1.30 \mathrm{E}+11$ & $1.30 \mathrm{E}+11$ & $2.30 \mathrm{E}+11$ & 3.10E-01 \\
\hline Mixed agriculture & $2.60 \mathrm{E}+10$ & $2.60 \mathrm{E}+10$ & $4.70 \mathrm{E}+10$ & 3.50E-01 \\
\hline Mixed urban & $3.70 \mathrm{E}+09$ & $3.70 \mathrm{E}+09$ & $6.60 \mathrm{E}+09$ & $1.90 \mathrm{E}-01$ \\
\hline Recreation and open space & $1.40 \mathrm{E}+09$ & $1.40 \mathrm{E}+09$ & $2.50 \mathrm{E}+09$ & 2.70E-01 \\
\hline Residential & $4.30 \mathrm{E}+09$ & $4.30 \mathrm{E}+09$ & $7.80 \mathrm{E}+09$ & $1.50 \mathrm{E}-01$ \\
\hline \multicolumn{5}{|c|}{ Pervious land units } \\
\hline Barren or vacant & $9.10 \mathrm{E}+07$ & $9.10 \mathrm{E}+07$ & $1.60 \mathrm{E}+08$ & $3.50 \mathrm{E}-01$ \\
\hline Commercial and services & $4.50 \mathrm{E}+10$ & $4.50 \mathrm{E}+10$ & $8.10 \mathrm{E}+10$ & $1.40 \mathrm{E}-01$ \\
\hline Forest & $1.30 \mathrm{E}+07$ & $1.30 \mathrm{E}+07$ & $2.30 \mathrm{E}+07$ & 7.70E-01 \\
\hline Industrial & $4.50 \mathrm{E}+09$ & $4.50 \mathrm{E}+09$ & $8.10 \mathrm{E}+09$ & $1.10 \mathrm{E}-01$ \\
\hline Intensive livestock & $1.10 \mathrm{E}+12$ & $1.10 \mathrm{E}+12$ & $2.10 \mathrm{E}+12$ & 4.70E-01 \\
\hline Mixed agriculture & $2.40 \mathrm{E}+11$ & $2.40 \mathrm{E}+11$ & $4.30 \mathrm{E}+11$ & 5.30E-01 \\
\hline Mixed urban & $3.30 \mathrm{E}+10$ & $3.30 \mathrm{E}+10$ & $5.90 \mathrm{E}+10$ & 2.90E-01 \\
\hline
\end{tabular}

Figure 16A shows the comparison between simulated and measured hourly bacteria concentrations at sample site MC for the 11/12/2003-11/13/2003 storm. The MC site is in the main channel of Mill Creek, a more natural, unlined channel about $0.5 \mathrm{mi}$ downstream of the terminus of the Cucamonga Creek concrete-lined channel. Discharge at this site can be high, and represented an integrated response of runoff to many upstream land uses. The hourly bacteria concentrations simulated for MC included results obtained using the uncalibrated (regional) parameters and the calibrated parameters. All results indicated a rapid increase in bacteria concentration (above the baseflow concentration of about $30 \mathrm{cfu} / 100 \mathrm{~mL}$ ) during the rising limb of the hydrograph. The peak bacteria concentration occurs between the two streamflow peaks of the hydrograph that occurred for this storm. The second hydrograph peak is much higher than the first peak, and resulted in dilution of the simulated bacteria concentration due to depletion of the bacteria stored (as a non-point source term) on the upstream IMPLNDs and PERLNDs. Although the simulated bacteria concentrations for the calibrated model reasonably matched the measured concentrations associated with the first hydrograph peak, concentrations associated with the second, higher hydrograph peak were underestimated. The measured concentrations did not indicate dilution during flow represented by the second peak. Results using the uncalibrated parameters showed a response to streamflow similar to that using the calibrated parameters, but the resulting concentrations were about 5 to 8 times lower than the concentrations in the calibrated model, whereby the model greatly underestimated the measured concentrations. 
$\boldsymbol{A}$

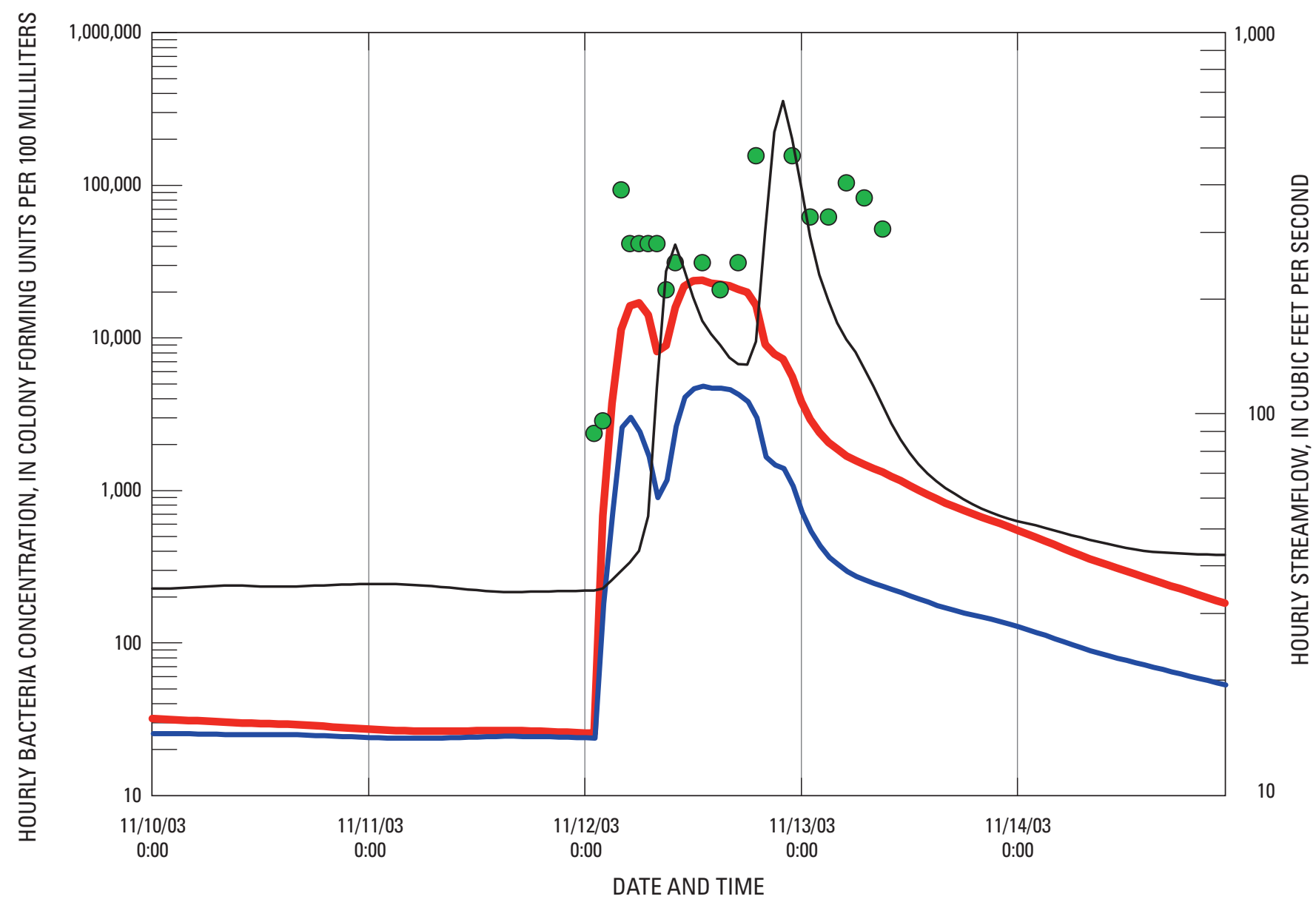

EXPLANATION

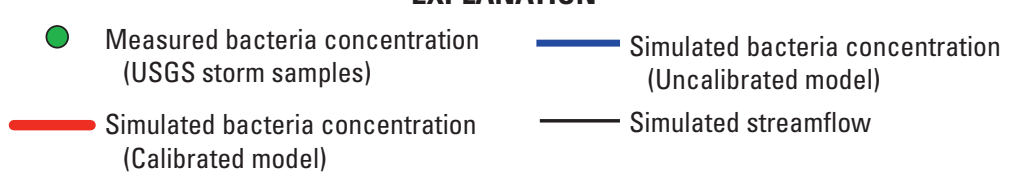

Figure 16. Simulated and measured storm-flow bacteria concentrations for $A$, storm of 11/12/2003-11/13/2003 at site MC, and for storms of 2/2/2004 and 2/22/2004 at $B$, sample site INDND, $C$, sample site INDD, D, sample site RECND, $E$, sample site RECGC, $F$, sample site RECD, G, sample site RESD, $H$, sample site SC, I, sample site D, and J, sample site MC reach in the Chino Basin, California. USGS, U.S. Geological Survey.

Figure 16B compares simulated and measured bacteria concentrations for the IndND site (industrial land use, not near intensive livestock land use; table 2) during the February 2004 storm period. This sample site is a street gutter having a relatively large upstream area (approximately 118 acres) that causes the street to be prone to flooding. The flow conduit is represented in the model as a first order stream. Values for the simulated bacteria concentrations from the calibrated model reasonably matched the measured values, although the time of the simulated peak concentrations did not match the measured peak concentration for the 2/22/2004 storm, again because of the dilution effect simulated by the model. The results for the uncalibrated model indicated under-simulation of the measured concentrations, with more dilution in response to the higher discharges. Nuisance flow between storms causes a uniform flow of about $0.01 \mathrm{ft}^{3} / \mathrm{s}$ and a uniform bacteria concentration of about 600 to $700 \mathrm{cfu} / 100 \mathrm{~mL}$ for both calibrated and uncalibrated models (nuisance flow is represented the same way for both models). 


\section{B}

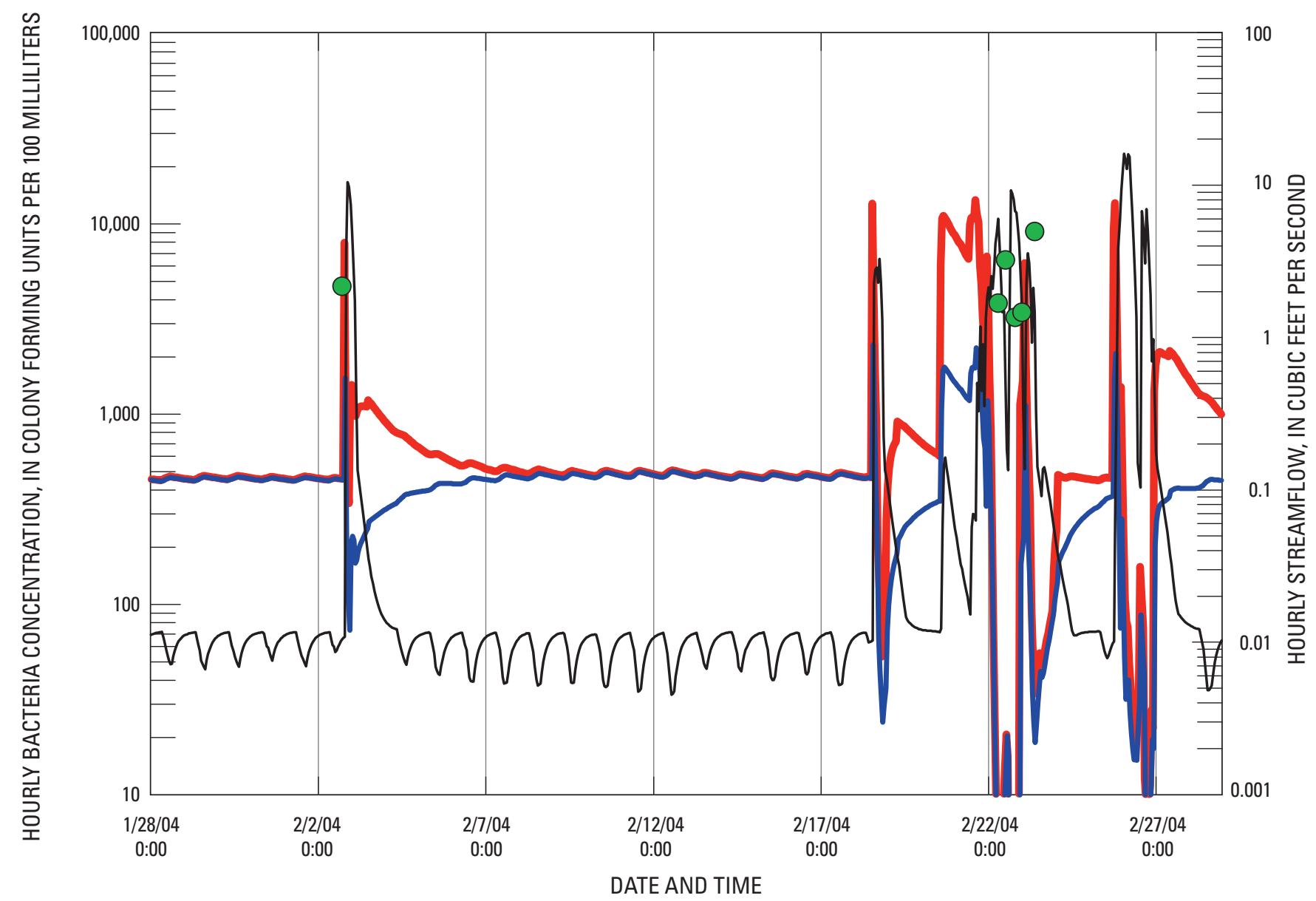

\section{EXPLANATION}

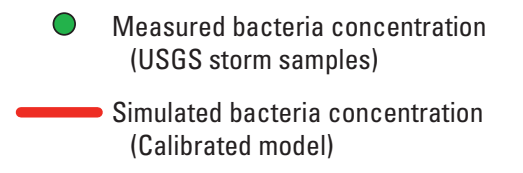

Figure 16. Continued

The relation between simulated streamflow and simulated bacteria concentration is complex because the peak bacteria concentration increases rapidly during the rising limb of the hydrograph, and the magnitude of the peak bacteria concentration depends on preceding conditions (washoff from preceding storms diminishes the available supply) and on the amount of dilution following the initial washoff. In addition, high bacteria concentrations are often simulated for very low flows. For these reasons, there was no direct correlation between simulated stream flow and simulated bacteria concentrations for the small catchment areas represented by a single land (PERLND and IMPLND) or reach (RCHRES) segment. In some cases, there appeared to be an inverse correlation between the peak of the streamflow hydrograph and the peak bacteria concentration (as in the case of the $2 / 22 / 2004$ storm) because a previous storm had depleted the bacteria storage component for the land surface and, following the initial washoff, continued runoff generated by the storm diluted the bacteria concentration in the reach.

Figures 16C (sample site IndD) and $\underline{16 D}$ (sample site RecND) show calibration results obtained for sites having very low simulated flows because of the very small upstream areas contributing runoff to these sites. Simulated bacteria concentrations in simulated flows of $0.0005 \mathrm{ft}^{3} / \mathrm{s}$ and less were excluded from the analysis because of the high uncertainty associated with such low flows. However, this did not affect the comparison with the measured bacteria concentrations because simulated flows during the sampled 2/2/2004 and 2/22/2004-2/23/2004 storms, though still relatively low, were well above the $0.0005 \mathrm{ft}^{3} / \mathrm{s}$ screening threshold that was chosen for evaluation of model results. 


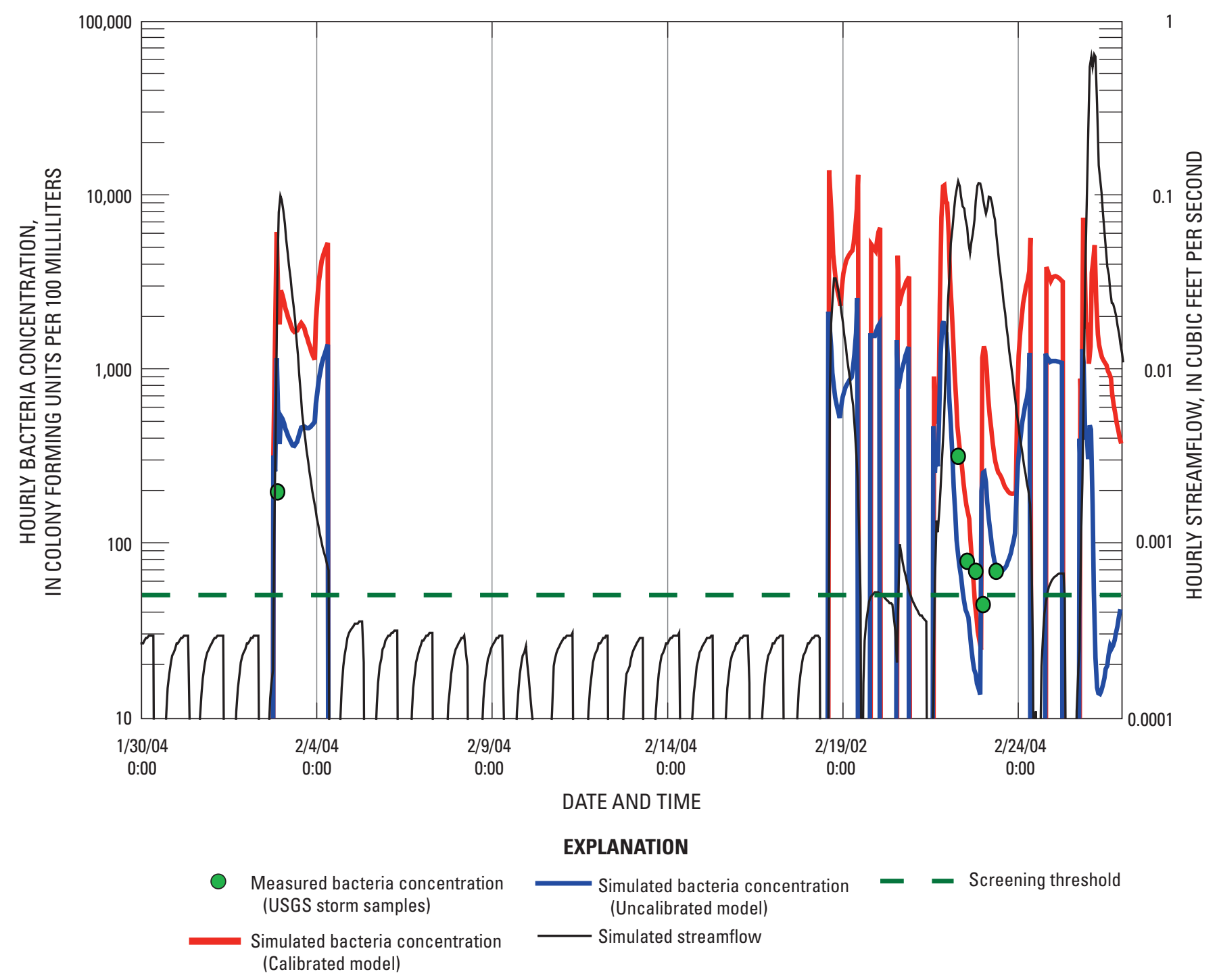

Figure 16. Continued

Results for sample site IndD (fig. 16D) indicate that the calibrated model provides a better fit than the uncalibrated model to the measured concentrations for the 2/2/2004 storm and the latter part of the 2/23/2004 storm; the uncalibrated model underestimated concentrations. Comparison with the results obtained for sample site IndND indicates the difficulty in providing a good fit to both sites representing the industrial land use; a good fit to one site caused concentrations to be overestimated or underestimated at the second site. For example, the measured concentrations for sample site IndND indicated no dilution during the peak storm flows of 2/22/2004-2/23/2004 storm, whereas the measured concentrations for sample site IndD indicated a strong dilution in response to the peak storm flows.
Figure $16 D$ indicates that the bacteria concentrations simulated by the calibrated model are similar to the measured concentrations. Simulation results match the measured concentration results for the $2 / 2 / 2004$ storm, but the model underestimates concentrations at the hydrograph peak during the $2 / 23 / 2004$ storm because of dilution. The uncalibrated model underestimates concentrations more than the calibrated model. Simulated flows at the RecND site are very low (less than $0.1 \mathrm{ft}^{3} / \mathrm{s}$ for the peak flow 2/26/2004), and the $0.0005 \mathrm{ft}^{3} / \mathrm{s}$ screening limit was applied to the nuisance flows between storms (the nuisance flows were as low as $0.0001 \mathrm{ft}^{3} / \mathrm{s}$ ). For such low flows, the diurnal pattern of evaporation of water in the reach was pronounced. 
D

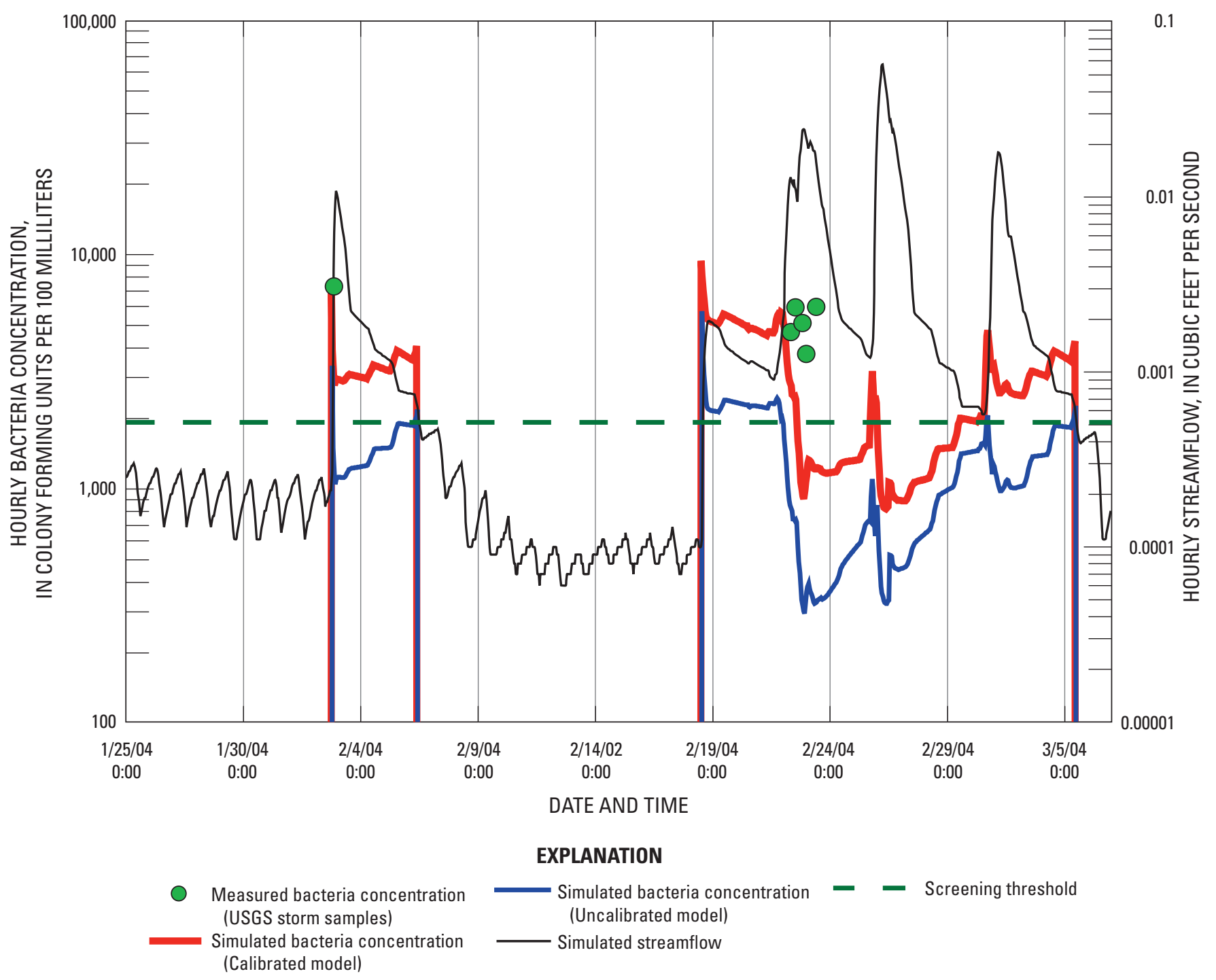

Figure 16. Continued

Simulation results at the RecGC sampling site did not match measured bacteria concentrations during the 2/2/2004 storm, but matched the data for the 2/23/2004 storm reasonably well (fig. 16E). The measured concentrations for the 2/23/2004 storm are well represented by the simulated dilution process occurring during the peak flow, and are very similar to the measured and simulated response to peak flow at sample site IndD (fig. 16C). The values simulated for the $2 / 2 / 2004$ storm by the uncalibrated model are closer to the measured value than those simulated by the calibrated model. The reverse is true for the 2/23/2004 storm, although the calibrated model values are only slightly closer to the measured value than the uncalibrated. Simulated nuisance flow at site RecGC is about $0.007 \mathrm{ft}^{3} / \mathrm{s}$, well above the $0.0005 \mathrm{ft}^{3} / \mathrm{s}$ screening limit, and the corresponding bacteria concentrations simulated for nuisance flow are about $1,000 \mathrm{cfu} / 100 \mathrm{~mL}$.

Simulation results for both the RecND and RecGC sites indicate that bacteria concentrations during nuisance flow may be overestimated by the model. However, because a uniform bacteria concentration is assumed for all nuisance inflows according to the total acreage of urban land uses contributing to each model reach section, it is expected that the nuisance flow concentrations are overestimated at some locations and underestimated at other locations. Varying the estimated nuisance flow concentrations according to contributing areas of separate land uses would likely improve model calibration, but this would also require additional field sampling of various nuisance flows based on land use. 


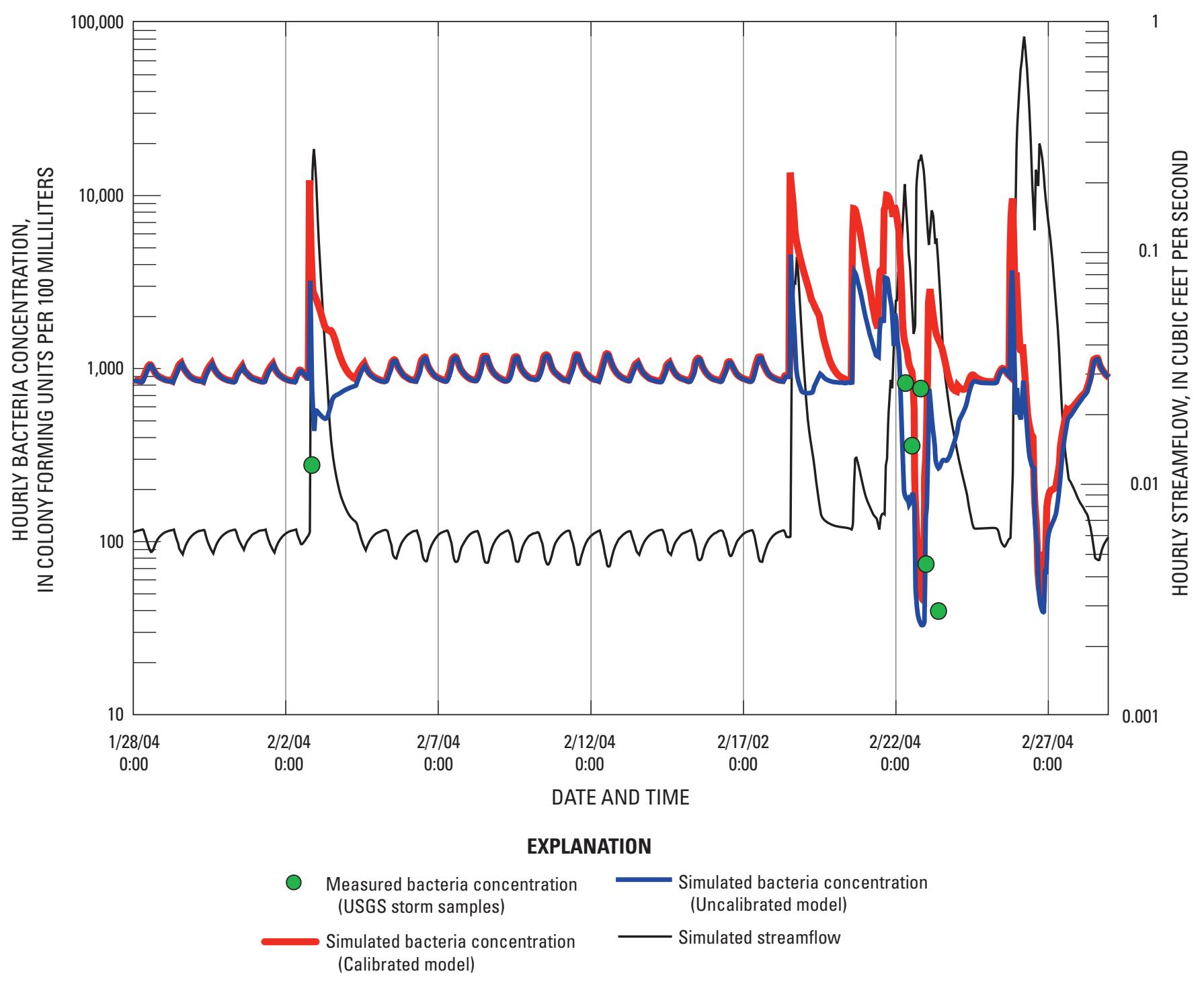

Figure 16. Continued

Simulation results for the RecD site (ig. $16 F$ ) are similar to the results for the RecGC site in terms of the comparison between measured and simulated bacteria concentrations. The calibrated model provides a poor fit to the single sample for the $2 / 2 / 2004$ storm, whereas the uncalibrated model provides an excellent fit. However, the calibrated model provides a good fit to the multiple samples for the 2/23/2004 storm, whereas the uncalibrated model underestimates the measured concentrations. The measured and simulated concentrations indicate dilution associated with the second hydrograph peak simulated for the 2/23/2004 storm. The simulated nuisance flow at this site is very low (about $0.002 \mathrm{ft}^{3} / \mathrm{s}$ ), but remains above the $0.0005 \mathrm{ft}^{3} / \mathrm{s}$ screening limit for all hourly time steps. The diurnal effect on the simulated flow and the bacteria concentration indicates the very high sensitivity to evaporation at such low flow rates and also indicates an inverse relation between flow and concentration. During low flows, the affect of evaporation is much greater than bacteria die-off (as defined by the RCHRES decay coefficient). 

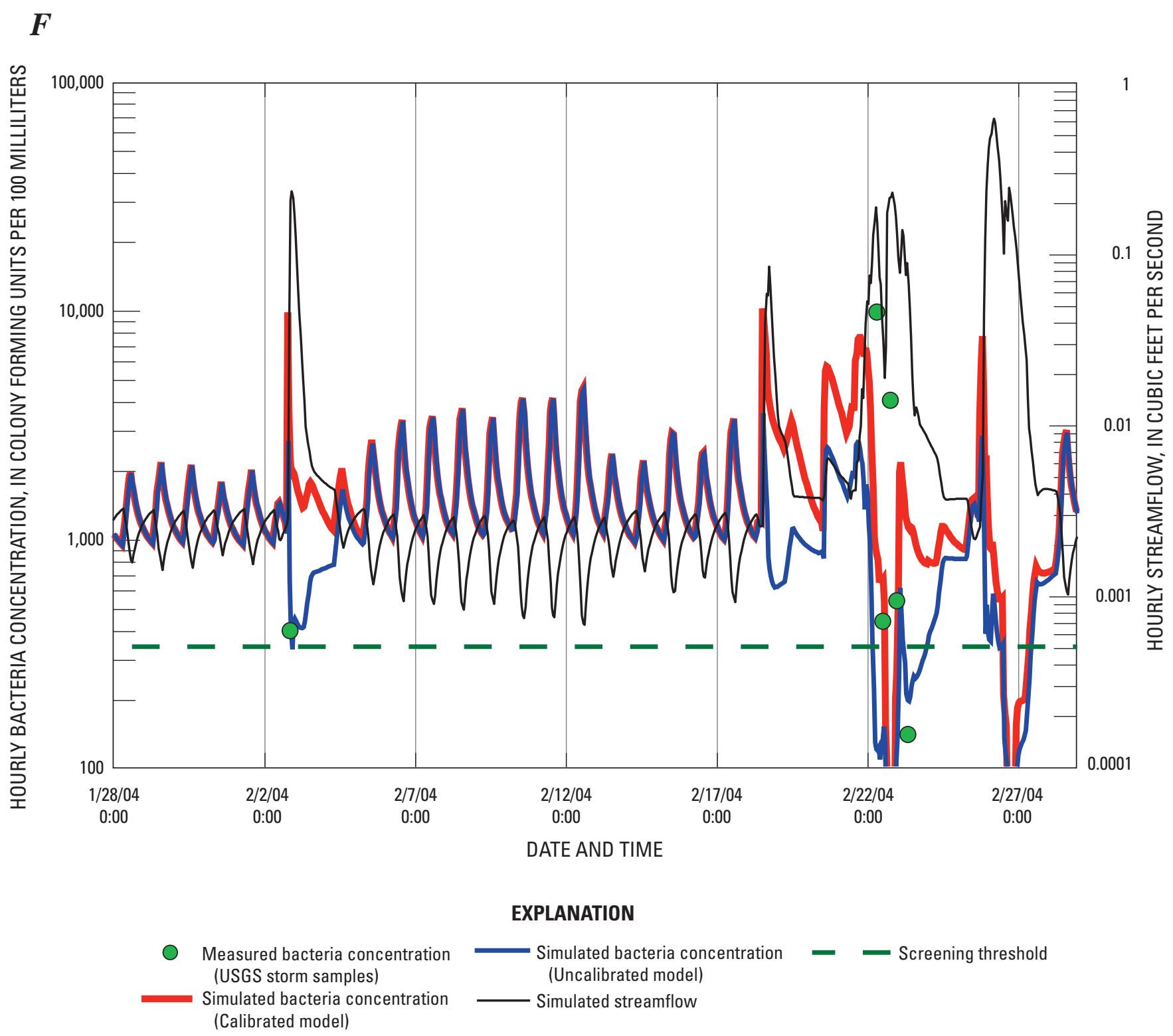

Figure 16. Continued

Simulation results for ResD (ig. 16G) and SC (ifg. 16H) are also consistent with results obtained at the other sites-a poor match to the single measured sample by using the uncalibrated model for the $2 / 2 / 2004$ storm, but a closer match using the calibrated model for the 2/23/2004 storm. At these sites, the simulated nuisance flows are less sensitive to hourly evaporation because the estimated reach area is much smaller. The simulated nuisance flow concentration is about $1,500 \mathrm{cfu} / 100$ $\mathrm{mL}$ at both sites. Concentrations simulated by the calibrated model matched the measured concentrations at both sites better than those simulated by the uncalibrated model for the February 23 storm.
Results indicate higher measured bacteria concentrations at site D (fig. 16I) than at the other sites, exceeding $100,000 \mathrm{cfu} / 100 \mathrm{~mL}$ during the February $23 \mathrm{storm}$. This site is in the channel of a well-defined natural drainage having a fairly large upstream area with most of the other land-use targeted sampling sites. Simulated stormflows were nearly $100 \mathrm{ft}^{3} / \mathrm{s}$ for the February 26 storm. The site is primarily affected by runoff from pervious mixed agricultural areas and dairies, and results indicate a better correlation between streamflow and bacteria concentration than at other sites. Simulated nuisance flows were approximately $0.09 \mathrm{ft}^{3} / \mathrm{s}$, and simulated nuisance-flow bacteria concentrations were close 


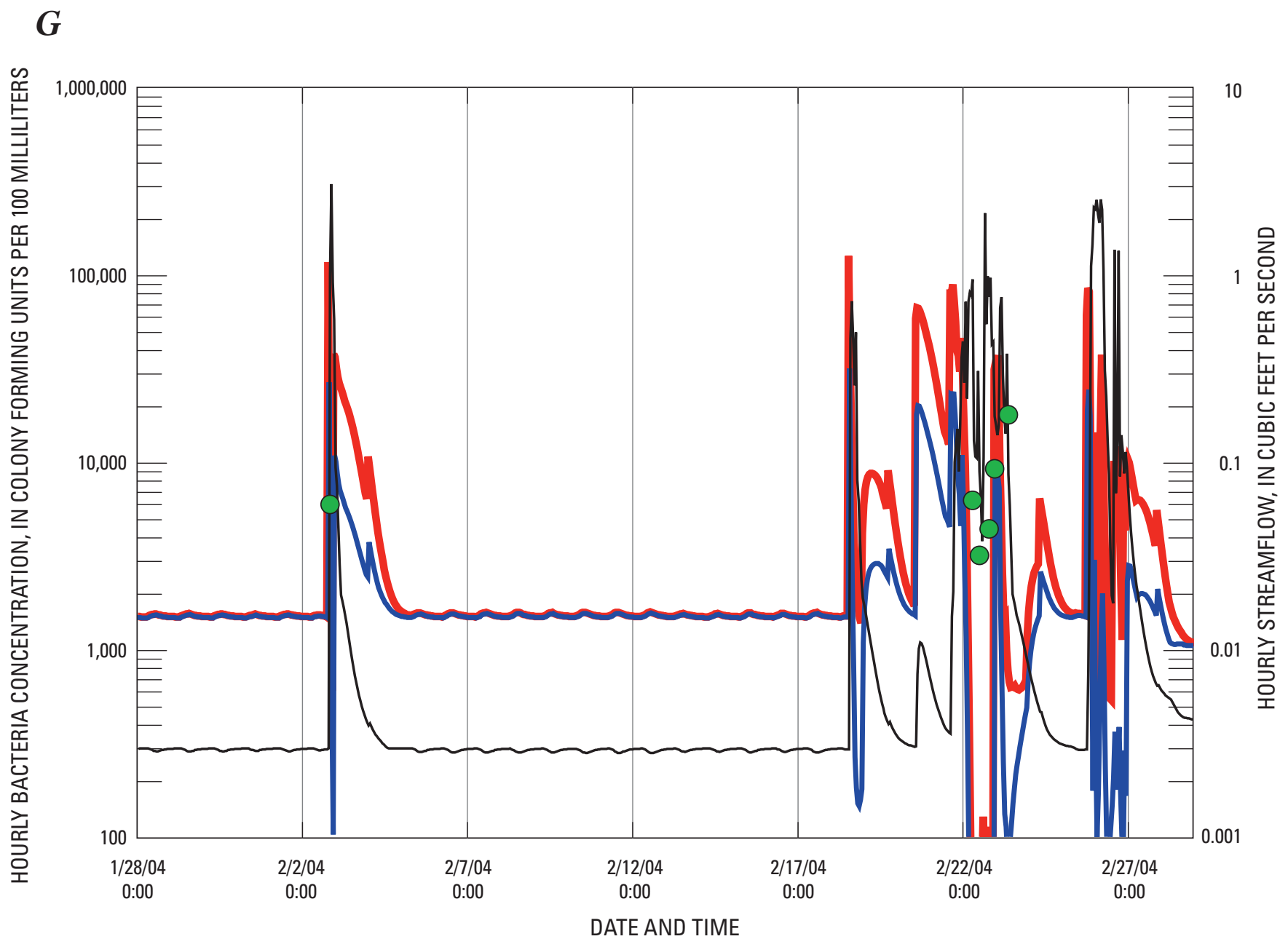

EXPLANATION

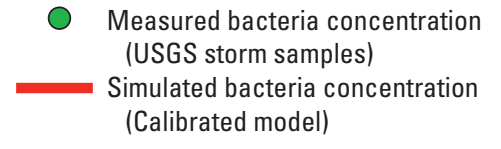

Figure 16. Continued

to $1,000 \mathrm{cfu} / 100 \mathrm{~mL}$. Fluctuations in simulated bacteria concentrations were diminished by the higher simulated flows. As with many of the other sites, simulation by the uncalibrated model matched the single measured concentration for the February 2 storm more closely than the calibrated model, but the calibrated model more closely matched the multiple samples for the February 23 storm. Both models underestimated the peak bacteria concentrations during the February 23 storm. However, the calibrated model was able to simulate the higher peak concentrations ( $>100,000 \mathrm{cfu} / 100 \mathrm{~mL}$ ) during the following storm of February 26, whereas the uncalibrated model cannot simulate concentrations greater than 15,000 cfu/100 mL. Figure 16J shows calibration results for the February 2004 storms at sample site MC and includes fecal coliform bacteria concentrations obtained from the monthly samples collected for the RWQCB study. The results indicate a good match between simulated and most measured storm-flow bacteria concentrations in the USGS storm flow samples. A generally good match was also observed for simulated and measured concentrations using the RWQCB data, especially for the flows associated with the February 2, February 18, February 26, and March 2 storms. A slightly better match was observed for the uncalibrated model and the RWQCB data. The concentrations simulated by the uncalibrated model reasonably match the USGS measured storm-targeted concentrations, but this model underestimated concentrations during the peak flows 


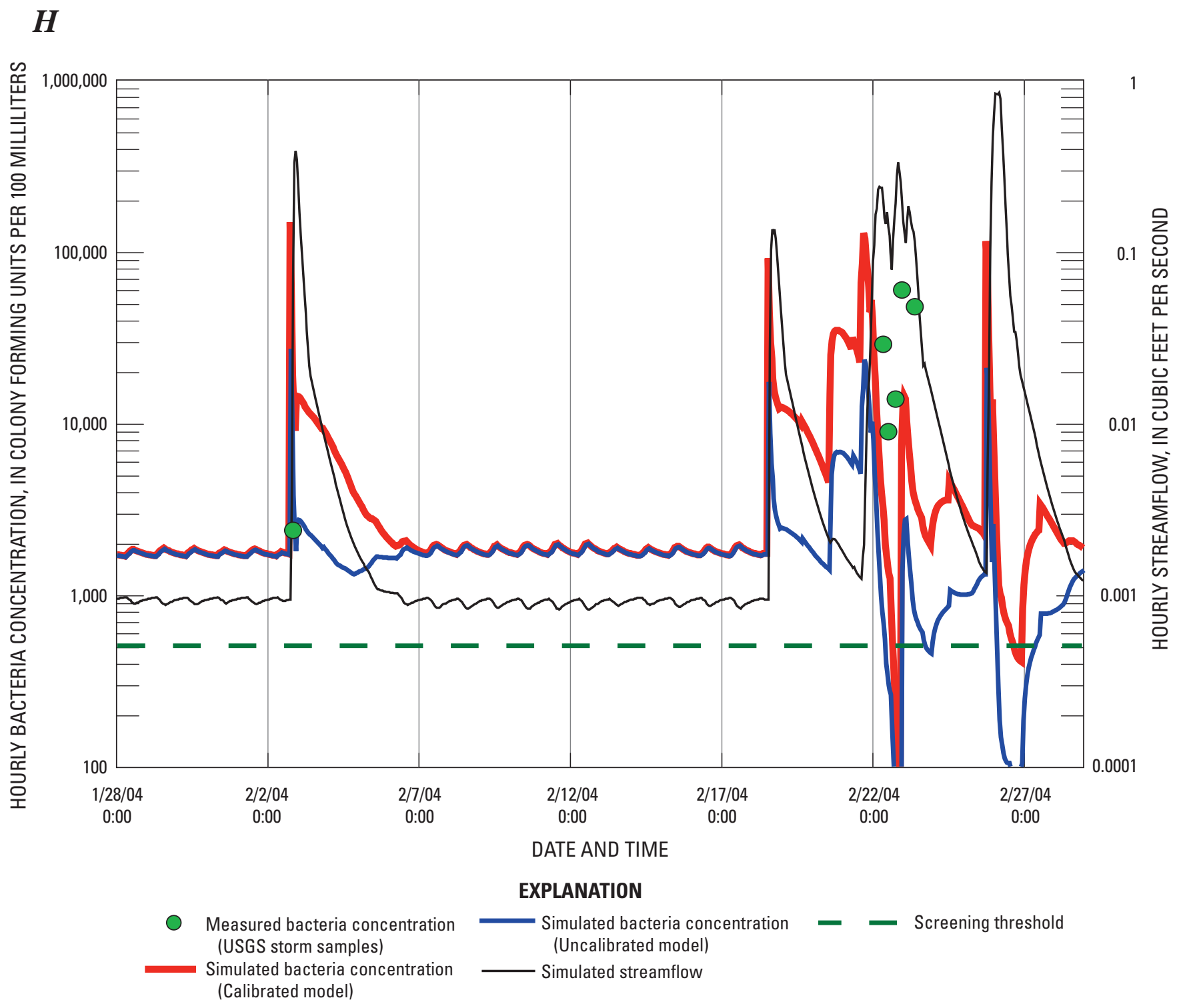

Figure 16. Continued

more than the calibrated model. Figure $16 \mathrm{~J}$ includes simulated hourly bacteria concentrations also that are based on modeled nuisance flows (all land area bacteria loading for PERLNDs and IMPLNDs was set to zero). The simulated nuisance flow concentrations of approximately $15 \mathrm{cfu} / 100 \mathrm{~mL}$ underestimated the measured concentrations of 100 to $200 \mathrm{cfu} / 100 \mathrm{~mL}$. However, the measured and simulated concentrations illustrate the importance of representing contaminated nuisance flow in the model, as opposed to assuming pristine (uncontaminated) nuisance flow.

Measured bacteria concentrations in the peak flows of November 12 and 13 (fig. 16A) were relatively high for this storm (up to $100,000 \mathrm{cfu} / 100 \mathrm{~mL}$ ). The simulation results correlated with the rapid increase in concentrations occurring during the rising limb of the first hydrograph peak and with dilution during peak flow. This effect is also indicated during the second peak of the storm hydrograph; however, the simulated results are lower than the measured concentrations for the second hydrograph peak.

Improving the match between the simulated and the measured values for the second hydrograph peak would require an increase in the land-use loading rates, and this in turn would result in overestimation of bacteria concentrations measured for other storms and at other locations. The bacteria concentrations measured during the November $12-13$ storm at the Mill Creek site may be high because of conditions unique to this storm, such as a flushing of sediments in retention basins and channels (this storm may represent unique conditions that would usually occur during the early part of the wet season). 


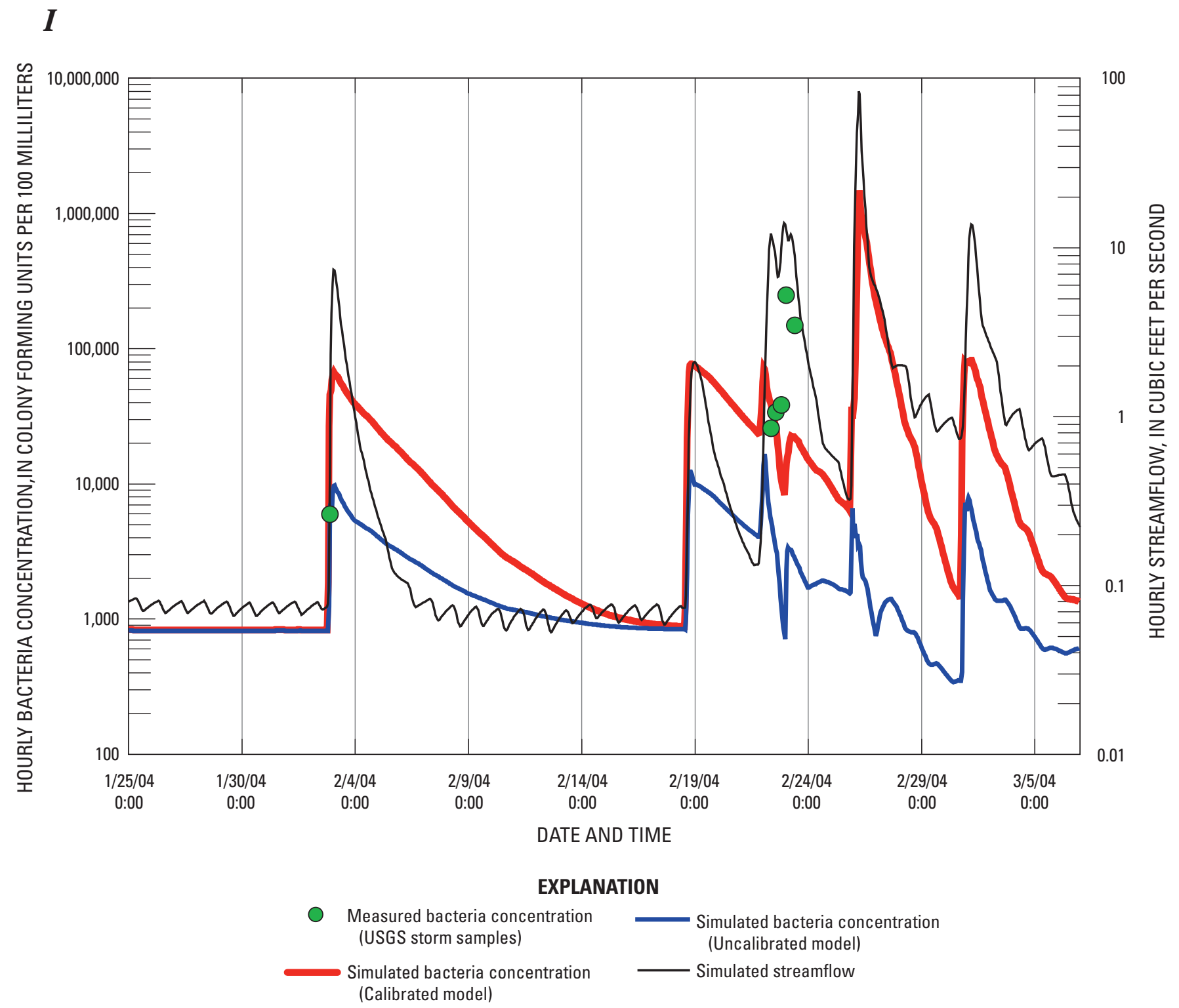

Figure 16. Continued

Quantifying the transport-model calibration results on the basis of simulated versus measured hourly bacteria concentration was difficult because the measured and the simulated concentrations varied greatly from hour-to-hour. To better quantify the transport model calibration results, the simulated average fecal coliform concentration was compared with the measured average concentration for each sampling time for storm-targeted sites (fig. 17). The $r^{2}$ value of the exponential regression line for simulated versus measured average bacteria concentrations was 0.58 , which was slightly higher than the $r^{2}$ values for simulated versus measured geometric mean concentrations and simulated versus measured maximum concentrations. The exponential regression line indicates a tendency of the model to overestimate bacteria concentrations for the sites having low bacteria levels (industrial and recreation and open space land uses), while those same land uses in the higher range of concentrations are underestimated. The regression line also indicates the tendency of the model to underestimate bacteria concentrations for most sites having high bacteria levels (intensive livestock and commercial and services land uses). Overall, the calibration was satisfactory given the variability observed between sites having the same land use (industrial, recreation and open space). The calibrated model provided a better overall match with the average bacteria concentrations than the uncalibrated model, which underestimated the average measured concentrations. 


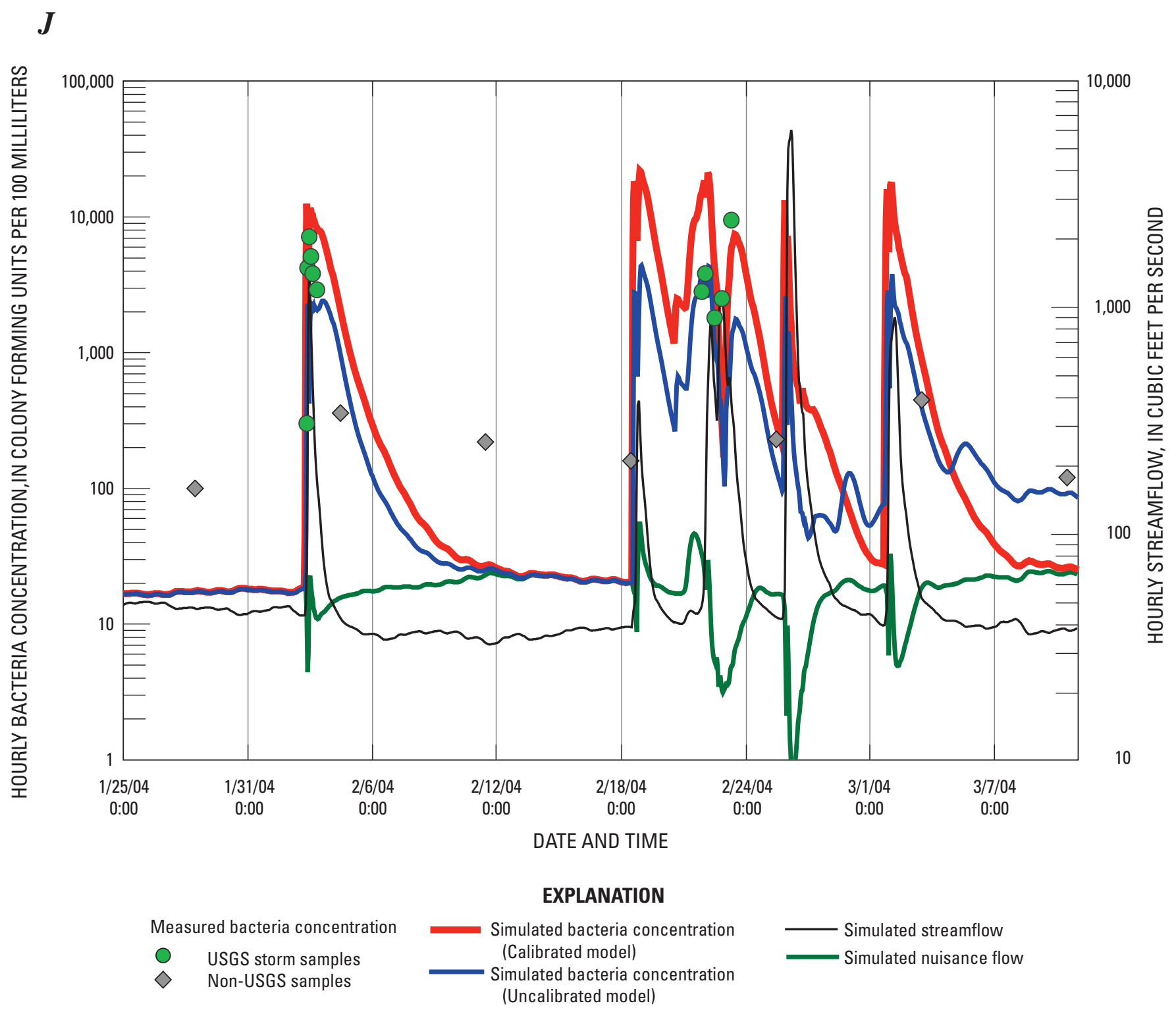

Figure 16. Continued

\section{Comparisons of Model Simulations with Supplemental Data from other Studies}

The water-quality data collected as part of this study was supplemented with water-quality data collected by the RWQCB Task Force and the OCWD. The supplemental data were used to improve the transport-model calibration and allow for model verification. The RWQCB supplemental data were available for multiple sampling sites in the Chino Basin study area and was helpful for developing an improved calibration because of the longer sampling time periods.

Additional sampling representing the integrated response in the main stream channels and additional sampling representing specific land uses is not represented by the data collected as part of this study.
Figure 18A shows the comparison of simulated daily and monthly bacteria concentrations and measured concentrations in samples collected by RWQCB at site D during the storms of 1996-1998. The daily simulations reasonably match the general range, magnitude, and temporal distribution of the measured concentrations. The daily results were used for comparison because the exact time of measurement for the RWQCB samples is not known. The monthly results are included to better illustrate the average temporal distribution of the simulated concentrations. The simulation results are consistent with the measured concentrations in indicating the maximum concentrations (exceeding 100,000 cfu/100 mL) resulting from the storm flows. 


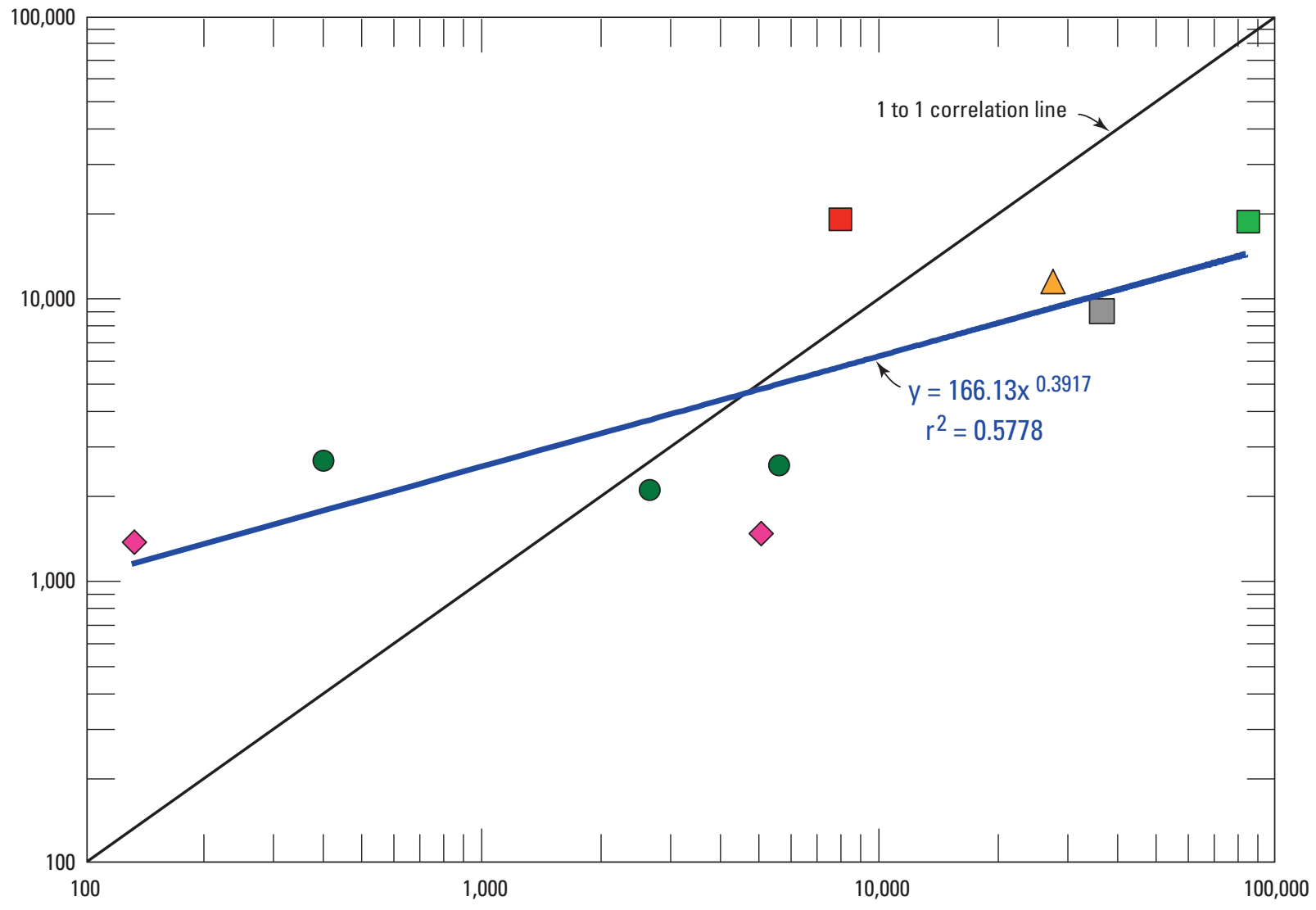

MEASURED BACTERIA CONCENTRATION, IN COLONY FORMING UNITS PER 100 MILLILITERS

\section{EXPLANATION}

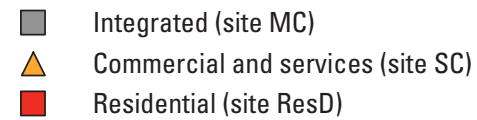

Dairies (site D)

Recreation and open space (3 sites)

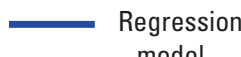

Industrial (2 sites)

Figure 17. Simulated and measured average bacteria concentrations in the Chino Basin, California, for the water-year 2004 storm and land-use targeted sampling sites used for model calibration.

The graph of the Mill Creek sampling site (MC) includes both storm-targeted bacteria data collected during the 2003-2004 winter season and supplemental data collected by the RWQCB (fig. 18B). The 2003-2004 storm-targeted data (USGS storm samples) are from the daily averages for the sampling dates. The storm-targeted data for samples collected during the storms of 2004 show higher bacteria concentrations than the data for the concentrations from the lower-flow samples collected during 2004 and most of the RWQCB samples collected before water-year 2004, because these samples better represent non-storm-flow conditions. Although nuisance flow is a significant part of the total base flow at the Mill Creek sampling site, wastewater effluent is a larger part of the base-flow component and helps dilute the higher concentrations usually associated with nuisance flow. Simulated nuisance flow concentrations of 20 to $30 \mathrm{cfu} / 100 \mathrm{~mL}$ compare well with the minimum concentrations represented by the RWQCB data. However, the RWQCB samples for the dry period in water-year 2002 indicate elevated concentrations in nuisance flow (between 800 and 3,000 cfu/100 mL), and these are not well represented by the model. It is likely that the low-flow sampling is sensitive to localized point sources of contamination which are not explicitly included in the model. In addition, the elevated concentrations for the low flows may indicate bacteria regrowth in the Cucamonga Creek channel, which is not represented by the model. Comparison of the monthly results for the calibrated and uncalibrated models indicates the higher average concentrations simulated by the calibrated model, which better matches the higher storm flow concentrations and the overall average concentration measured at this site. However, for certain periods, the uncalibrated model better matches the data. 
$\boldsymbol{A}$

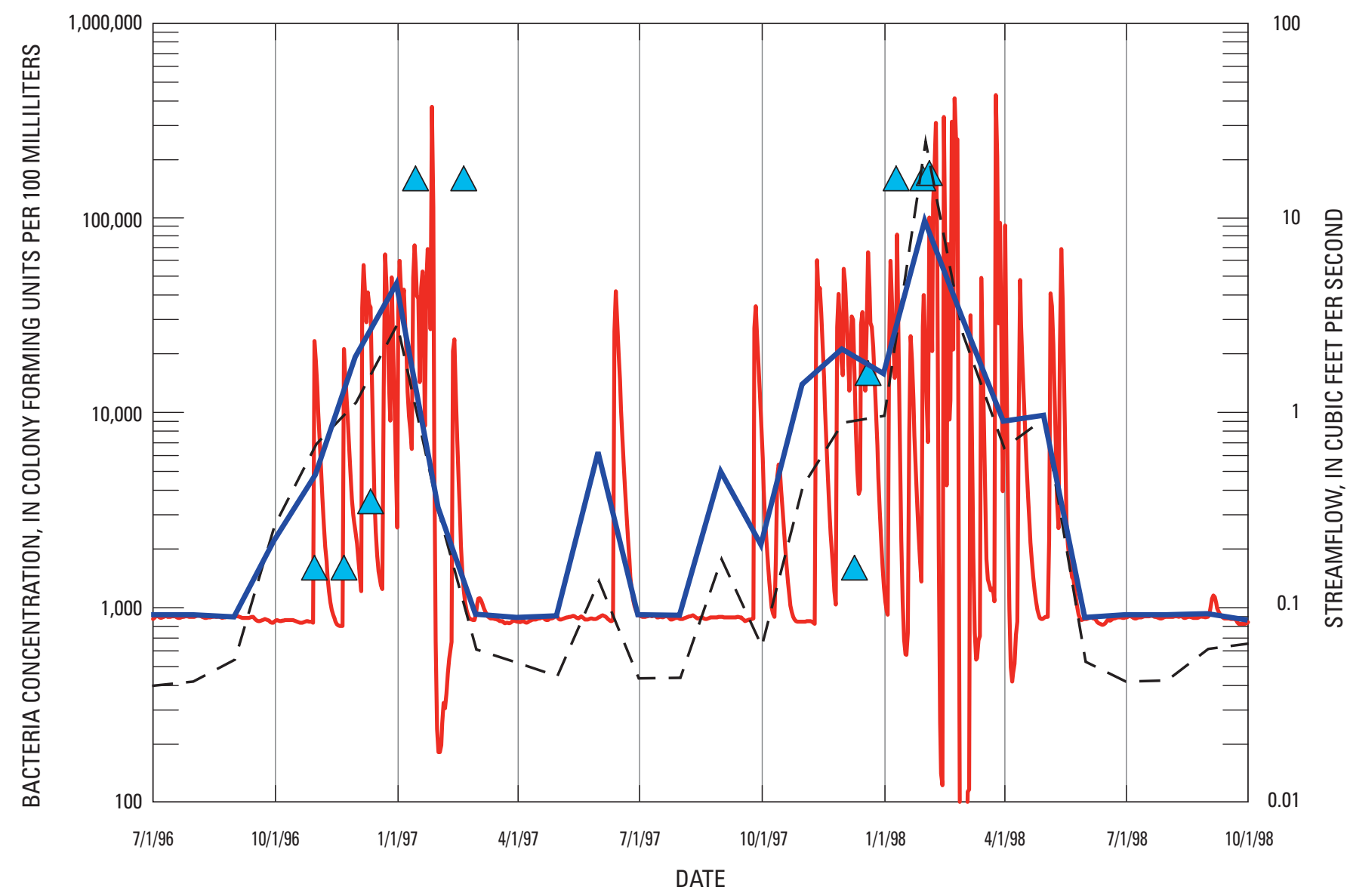

EXPLANATION
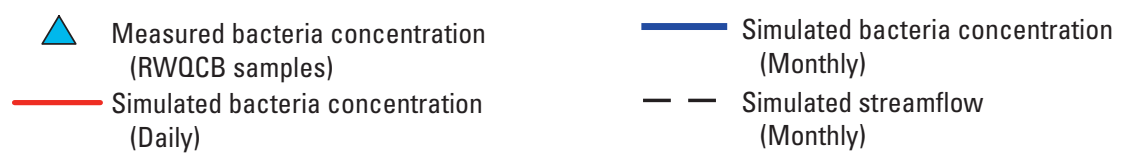

Figure 18. Simulated streamflow and simulated and measured bacteria concentrations at $A$, sample site $D, 1996-1998, B$, sample site MC, 2002-2004, C, sample site CCM2, 2002-2004, D, sample site CHIS, 2002-2005, E, sample site IHC, 2002-2005, F, sample site BVAM, 2002-2004, and G, sample site PPOC, 2002-2004 in the Chino Basin, California. RWOCB, Regional Water Quality Control Board; USGS, U.S. Geological Survey; OCWD, Orange County Water District.

Measured fecal coliform concentrations for Cucamonga Creek at sample site CCM2 (upstream of the location of RP-1 effluent discharge into Cucamonga Creek channel) indicate that the maximum measured bacteria concentration occurred between storm events during water-year 2002 instead of during storms (fig. 18C). The higher concentrations measured during the low-flow conditions in water-year 2002 were consistent with the data for sample site MC. The data indicate that the nuisance flows are likely to have relatively high bacteria concentrations (in some cases even higher than concentrations during storm flows) at some locations. This location is upstream of areas used for the mixed agriculture and intensive livestock, and is somewhat comparable to land used similarly that affect the Chino Creek at Schaeffer Ave. sampling site (fig. 18D, sample site CHIS).

The data collected at the Chino Creek at Schaeffer Ave (CHIS) sampling site (fig. 18D), which was coincident with the location of the USGS stream gage 11073360 used for calibrating the stream flow component of the model, provided data for characterizing the integrated response in the main Chino Creek channel for 2002 through 2005. This location illustrates the effect of the OCWD water transfers that result in diluting the bacteria concentrations and lowering level of bacteria in nuisance flows. 


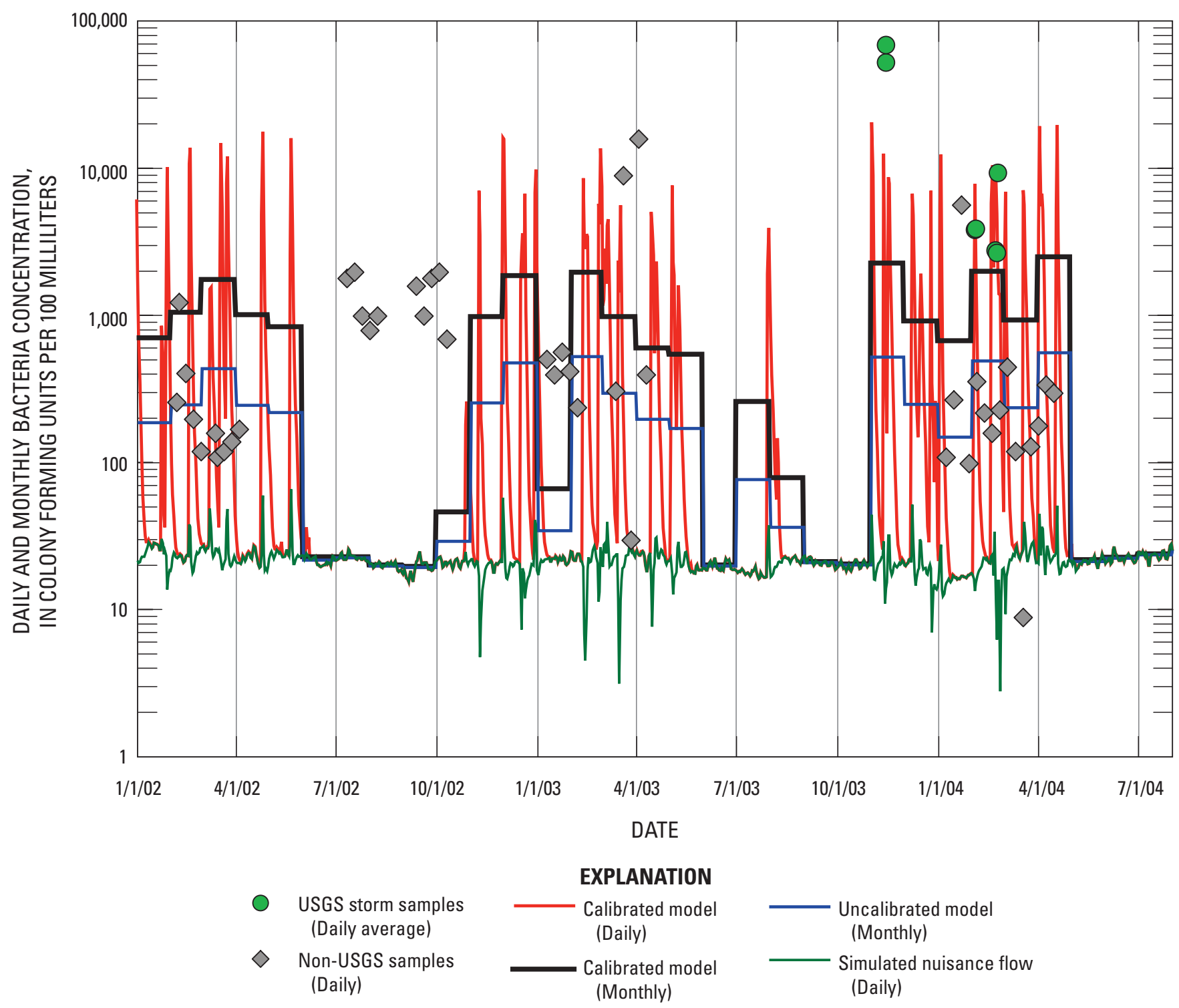

Figure 18. Continued

Measured concentrations at both the CHIS and CCM2 sites indicated that high bacteria loads were likely in the main stream channels because of nuisance flows and storm runoff from urban areas upstream of the mixed agriculture and intensive livestock land-use areas. The simulated bacteria concentrations in nuisance flow at the two locations ranged from 1,000 to $1,500 \mathrm{cfu} / 100 \mathrm{~mL}$, and this provided a better match with the available data than the simulation results based on a model that assumed pristine nuisance flow. However, the data indicated high variability in bacteria concentrations during low flow conditions, and this was not well represented by the uniform nuisance flow concentration assumed for the model. For some of the storm periods, the lower ( $<100 \mathrm{cfu} / 100 \mathrm{~mL})$ measured concentrations suggested that some storm flows diluted the bacteria concentrations, and this was well represented by the model. Comparing the monthly results for the calibrated and the uncalibrated models indicated the higher average concentrations obtained using the calibrated model best represented the actual concentrations. At sample site CHIS, the calibrated model more closely matched the OCWD samples used for model verification. 
$C$

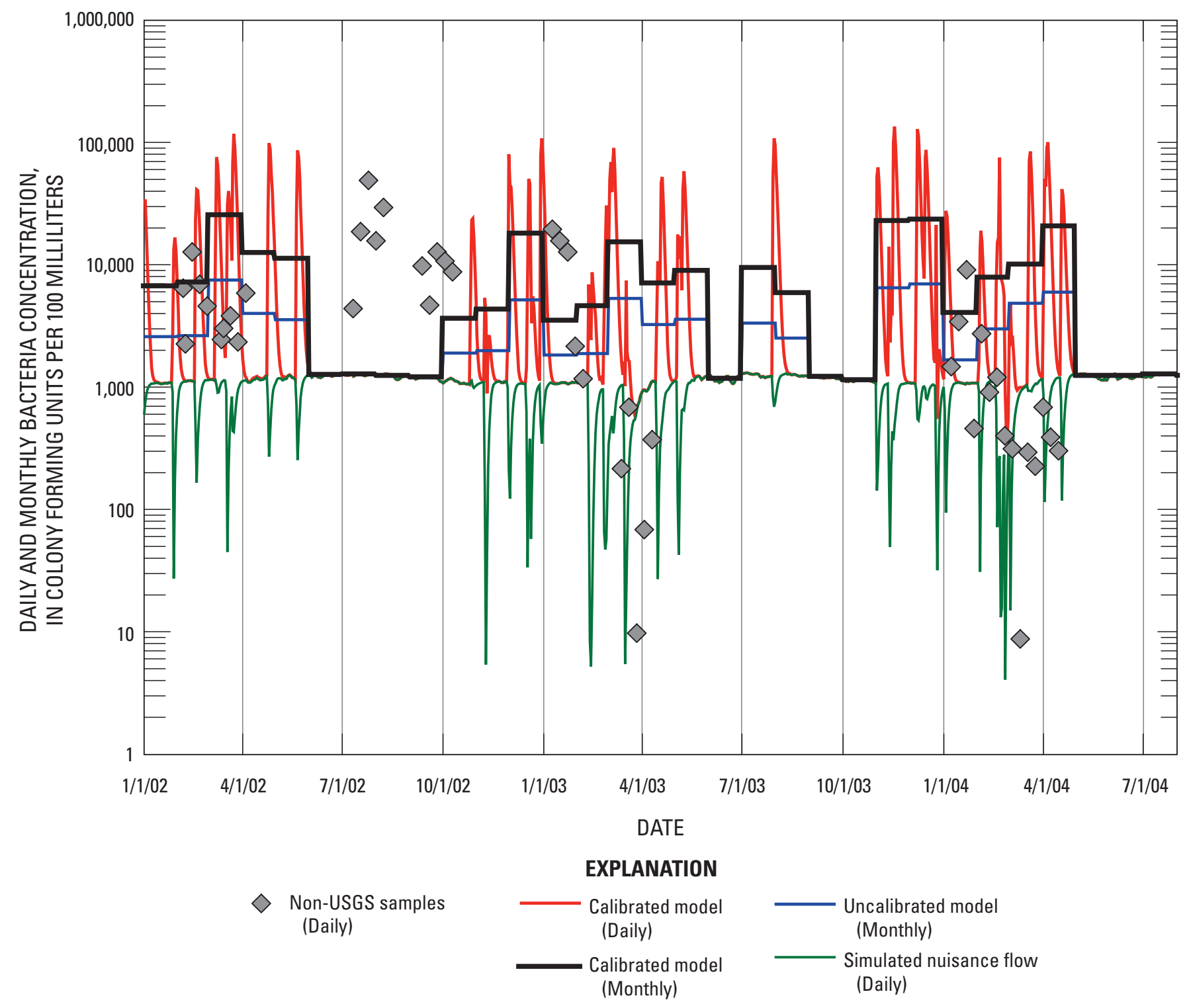

Figure 18. Continued

Natural background conditions were represented by the IHC site in San Antonio Canyon and illustrate the relatively low bacteria concentrations in the upland areas representative of natural, or background, conditions (fig. 18E). Simulated average monthly bacteria concentrations obtained using the calibrated parameters were compared with results obtained using the uncalibrated parameters; the uncalibrated parameters yielded higher concentrations because of higher loads for the natural land uses. However, neither the calibrated nor the uncalibrated model accurately simulated the peak bacteria concentration of $9,000 \mathrm{cfu} / 100 \mathrm{~mL}$ measured during the beginning of water-year 2003. This sample may represent point, rather than nonpoint, bacteria loading in the stream channel and thus was not represented by the model. The other samples, all of which had concentrations less than about $300 \mathrm{cfu} / 100 \mathrm{~mL}$, were more closely represented by the models. The OCWD samples were also included in the comparison and indicated very low bacteria concentrations for water-year 2005. The calibrated model simulated the OCWD samples used for model verification more accurately than the uncalibrated model. 


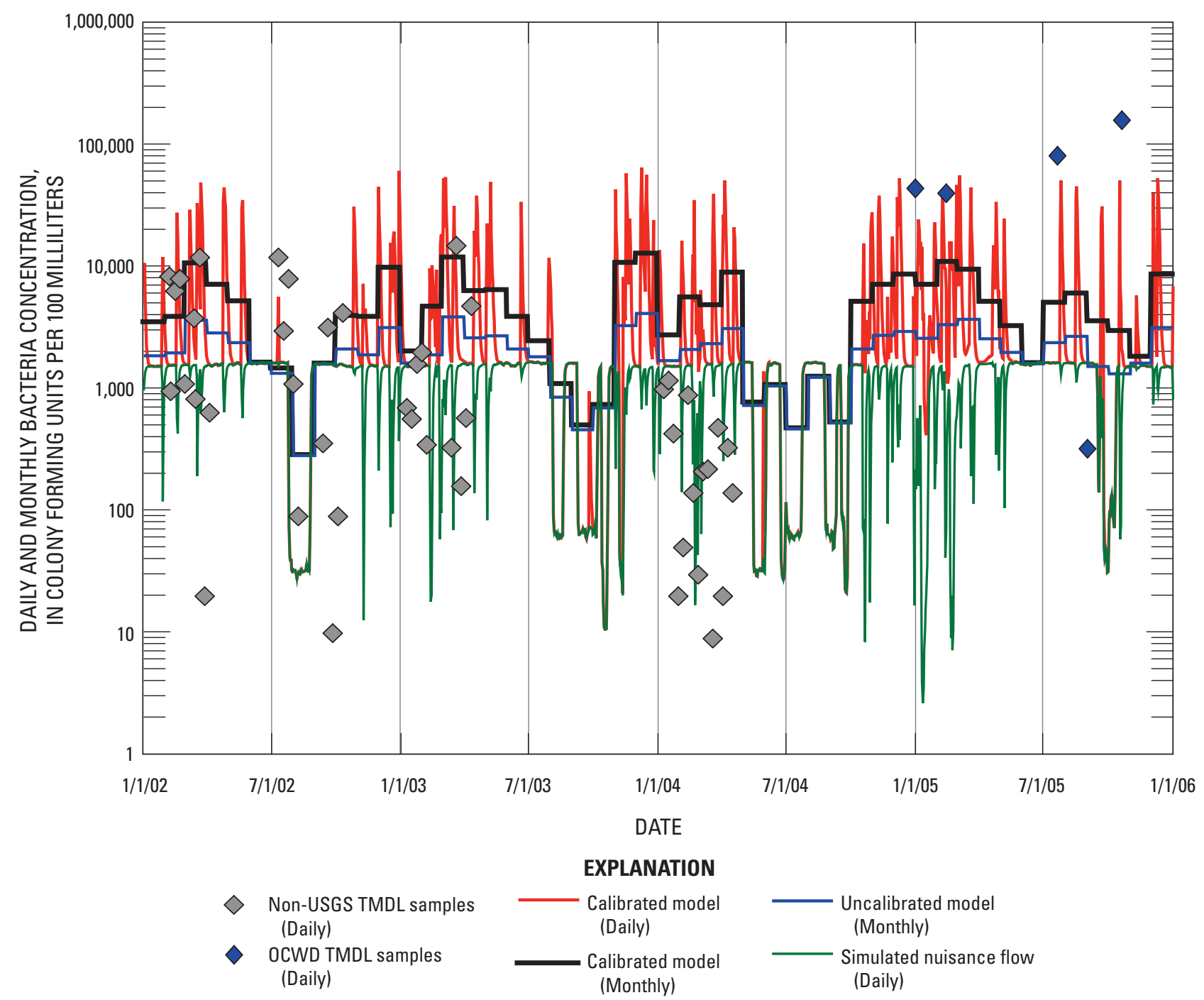

Figure 18. Continued

The data collected at the Bon View and Merrill Ave. sampling site (BVAM) confirmed the bounds for the combined mixed agriculture and intensive livestock land uses and indicated the condition under which pervious land requires very high flows to effectively transport bacteria, as shown by the very high bacteria concentrations measured during March, 2003 (fig. 18F). The calibrated daily model indicated peak daily concentrations consistently exceeding 100,000 cfu/100 $\mathrm{mL}$ in response to storm runoff, and this was supported by the field data. The uncalibrated model, in comparison, generally underestimated the measured bacteria concentrations at this site. The simulated nuisance flow of about $1,000 \mathrm{cfu} / 100 \mathrm{~mL}$ provided a good fit to the measured minimum concentration of about $900 \mathrm{cfu} / 100 \mathrm{~mL}$ obtained during water-year 2002. In general, the calibrated model provided a good fit to the range and temporal distribution of the water-year 2002 data.

The integrated site at Prado Park Lake outflow (PPOC) generally matches the daily and monthly bacteria 
$\boldsymbol{E}$

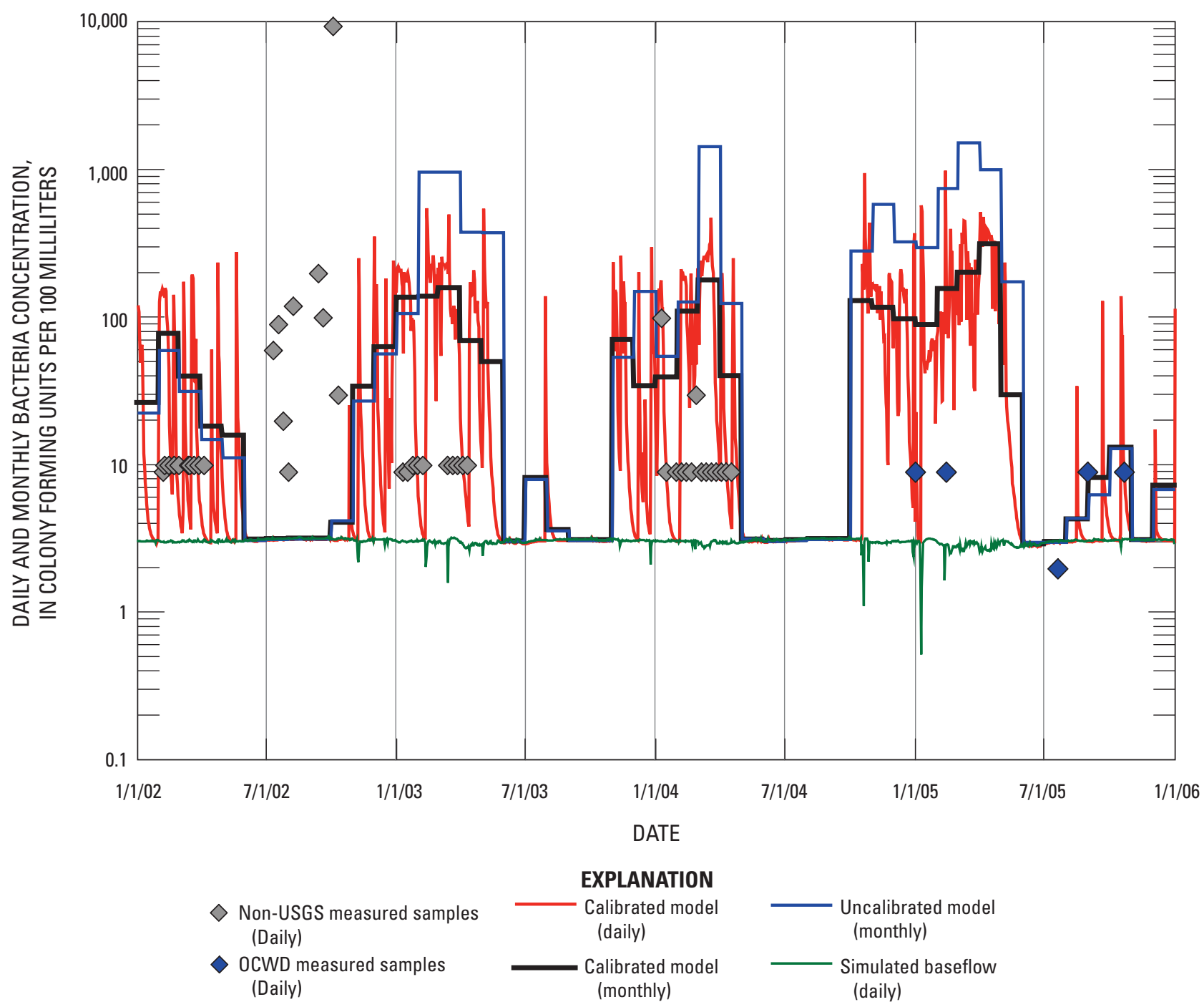

Figure 18. Continued

concentrations during storm-flow and higher flow conditions (fig. 18G). The calibrated model provides a good match to the timing and general magnitude of the measured peak concentration during the March 2003 storm flow conditions. The average monthly concentrations obtained using the calibrated model provide a good general fit to the measured concentrations, whereas results obtained using the uncalibrated model consistently underestimates the concentrations. For low-flow conditions, the calibrated model usually underestimates bacteria concentrations. However, increasing the simulated lowflow concentrations was difficult because (1) the inflows into Prado Park Lake from RP-1 were assumed to be pristine and this greatly diluted bacteria levels during low-flow conditions, (2) the residence time for water stored in Prado Park Lake caused most of the bacteria transported into the lake from upstream areas to decay, and (3) the bypass pipe underlying the lake and diverting low-flows directly into the lake outflow was not explicitly defined in the model. The bacteria in the diverted low flows would not undergo the dilution and die-off that would occur if discharged into the upstream part of the lake, as represented by the model.

For this study, the decay coefficients were kept consistent throughout the modeling domain for all RCHRES segments. 


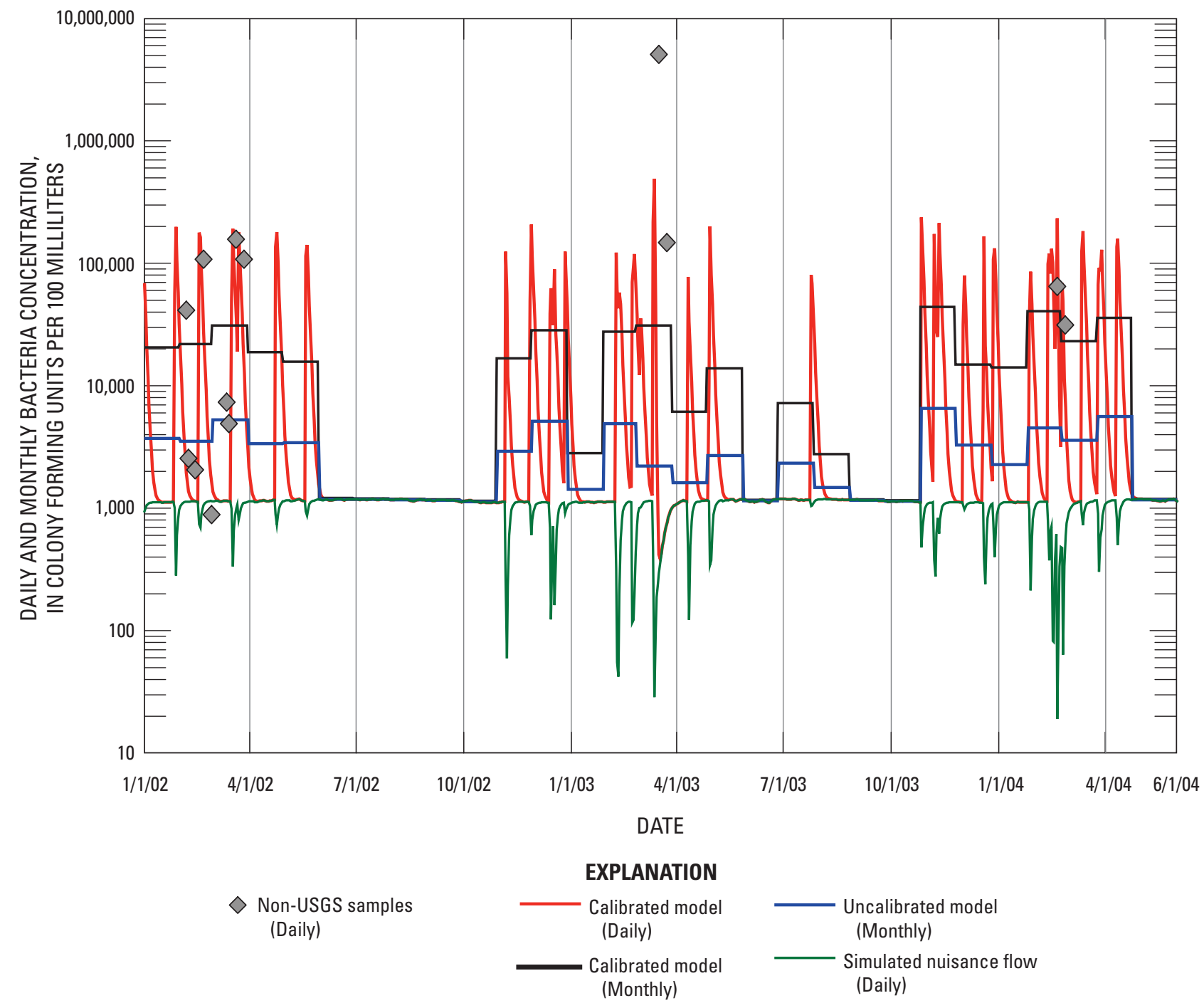

Figure 18. Continued

In some cases, such as Prado Park Lake, a different decay coefficient may improve model calibration. In many cases, the supplemental data were interpreted as representing base flow only (wastewater effluent, water transfers, and nuisance flow). However, in some cases, such as the Prado Park Lake outflow, the supplemental data represented, at least in part, the effect of storm runoff alone or the combined effect of storm-runoff and base-flow components.

Final model calibration included a comparison of simulated and measured average bacteria concentrations using all RWQCB monthly samples and all USGS storm-targeted samples (fig. 19). The calibrated transport model was verified by comparing simulated bacteria concentrations with the measured average bacteria concentrations in the OCWD WY2005 samples. The OCWD samples were available for multiple sites for water-year 2005. Figure 19 and table 12 show the calibration and verification analysis. The $\mathrm{r}^{2}$ value for both the calibration and the verification exponential regression lines is 0.78 . The slope of the calibration line is similar to that of the 1-to-1 line, whereas the slope of the verification 


\section{$\boldsymbol{G}$}

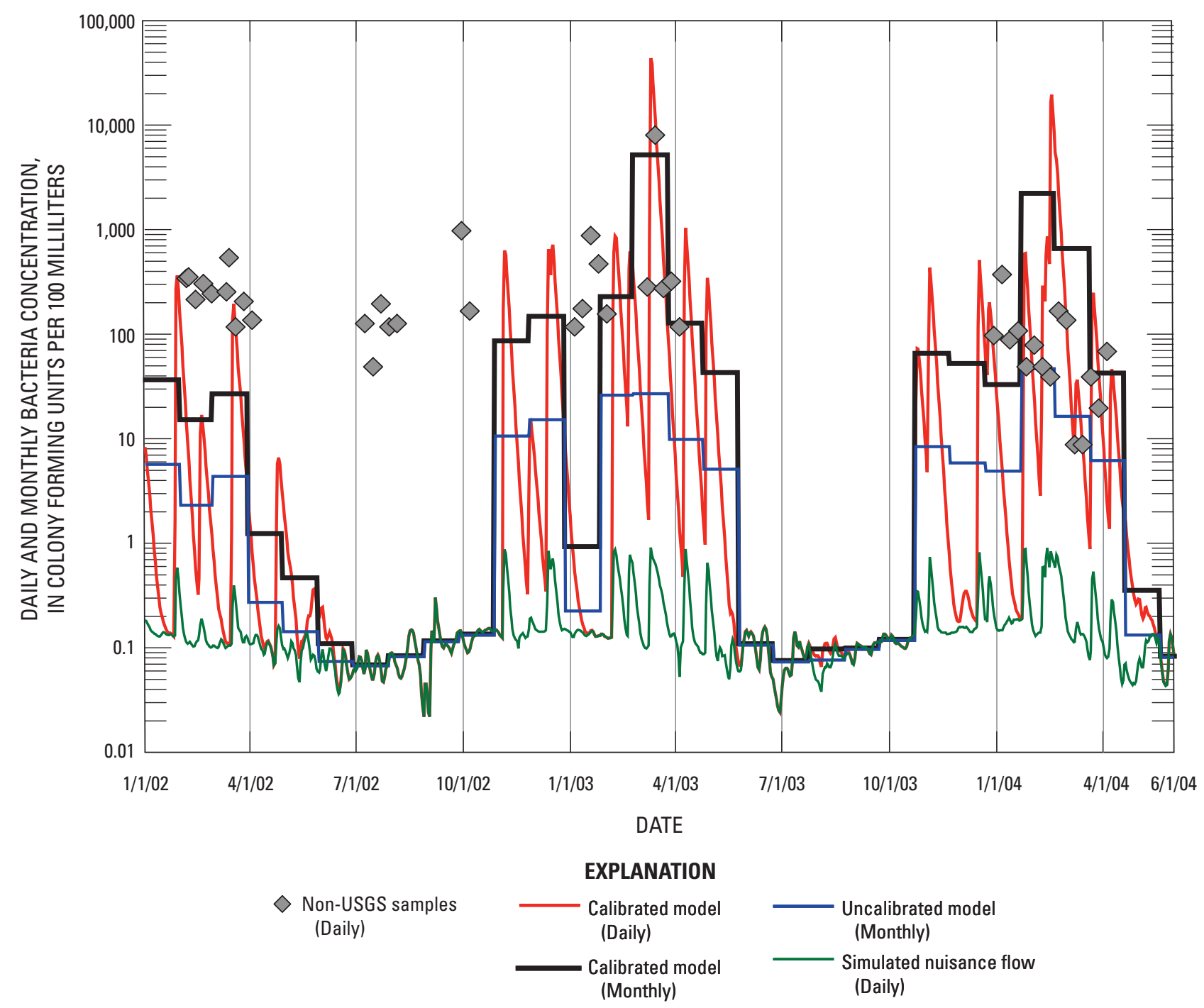

Figure 18. Continued

line is less similar, overestimating bacteria levels for the cleanest sites and underestimating bacteria levels for the most contaminated sites. Calibration results were improved by including (1) sample sites representing natural or background conditions (IHC and CCM1), (2) RWQCB storm-flow samples for 1996-1998 (labeled CBSW sites in figure 19), and (3) the most contaminated sample site, BVAM, which provided the most direct sampling of the intensive livestock land use. The OCWD samples indicated a slight bias towards higher measured bacteria levels relative to the other sample groups, causing the calibrated model to underestimate bacteria levels for the verification. The bias in the OCWD data may in part be due to improved sampling techniques.

Results in table 12 show summary statistics for measured and simulated fecal coliform concentrations for all samples collected in 1997-1998 and 2002-2004, including winter and summer flows, and storm flows. The statistics for the simulated concentrations were calculated using only the hourly simulations that corresponded to the time and date a measurement was made. For RWQCB and OCWD data, 12:00 pm (noon) was used as the sampling time (most samples were collected between 10 am and $2 \mathrm{pm}$ ). Statistics compared include average, geometric mean, maximum, and minimum bacteria concentrations. The highest average measured bacteria concentration of $452,931 \mathrm{cfu} / 100 \mathrm{~mL}$ was obtained at sample site BVAM from 13 samples collected for the RWQCB study (the 1997-98 storm flow samples and the 2003-2004 monthly samples were combined for the analysis). The highest average simulated bacteria concentration (based on the hourly simulations for 6 sampling dates and times) was $19,230 \mathrm{cfu} / 100 \mathrm{~mL}$ for the ResD storm sampling (and winter) site. 


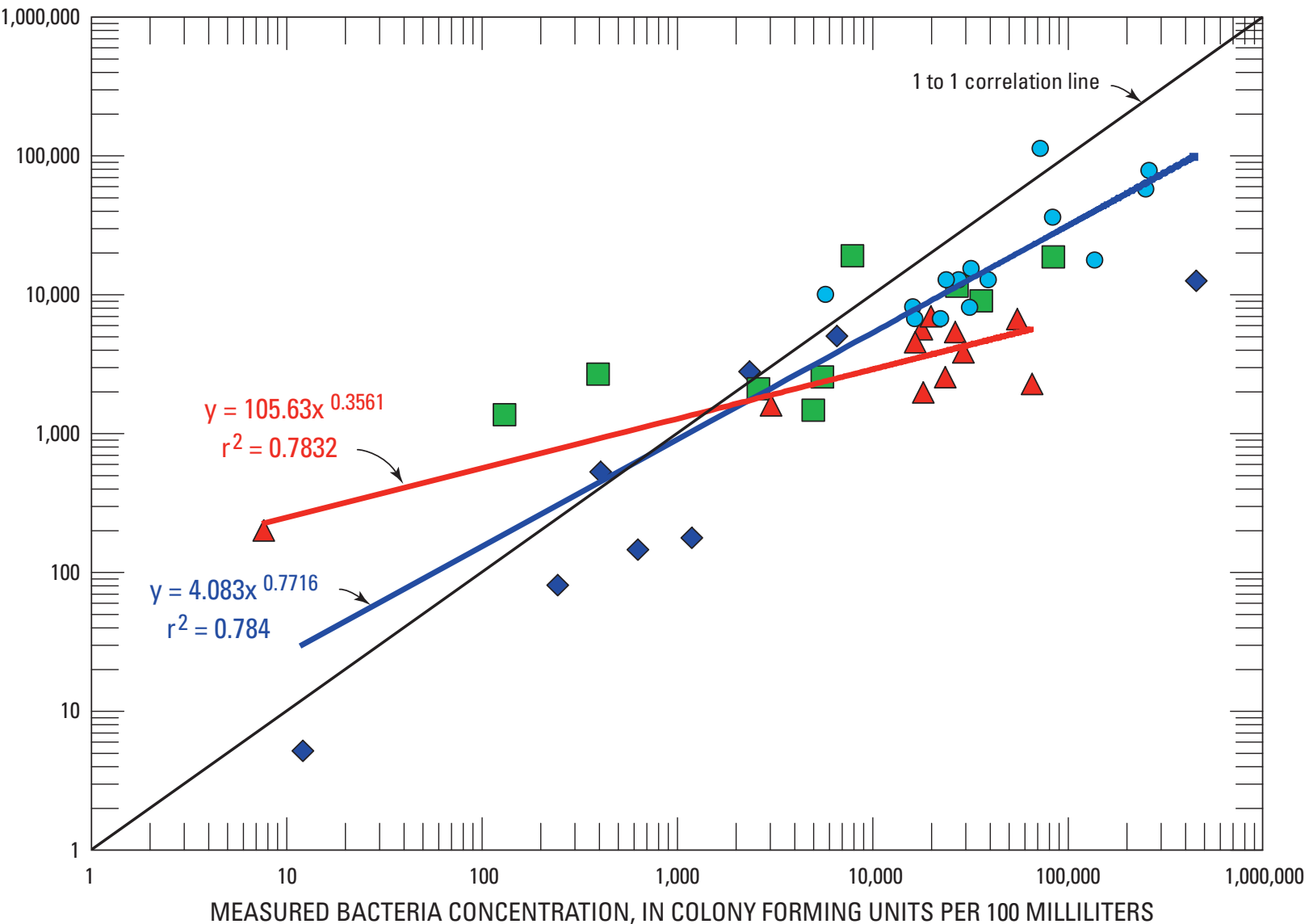

\section{EXPLANATION}

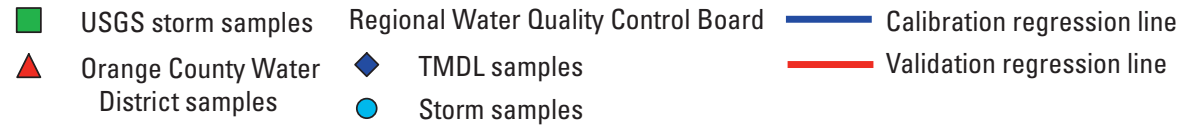

Figure 19. Simulated and measured average bacteria concentrations in the Chino Basin for all sampling sites used for model calibration and verification. TMDL, Total Maximum Daily Load; USGS, U.S. Geological Survey.

\section{Uncertainties in Modeling a System with Changing Conditions}

Critical model datasets used to develop parameters representing the hydrologic characteristics of the study area included the stream-channel and storm-drain network, the location and storage capacity of the larger retention basins, the land-use map, and the imperviousness map. These datasets were mostly based on features that existed during 1999-2000 and likely do not accurately represent past or future basin characteristics (the data is most accurate for the 1999-2000 time frame). In general, the trend of increasing population and urbanization has resulted in a decrease in pervious areas and natural drainages with time.
Additional uncertainties and limitations included the many simplifying assumptions used to define the hydrologic behavior of the basin and the processes controlling bacteria development and transport. Irrigation of pervious landscapes was not represented directly by the model. Increased soil moisture resulting from irrigation would likely generate more runoff relative to that generated on non-irrigated landscapes. Such characteristics were indirectly incorporated into the model by adjusting parameters during the model calibration process (the increased runoff should be accounted for by the stream flow record). 
Table 12. Calibration summary of simulated fecal coliform concentrations and measured indicator bacteria concentrations for 18 sampling sites in the Chino Basin, California.

[Location of some sites on figure 2 (green). Measured values are indicator bacteria concentrations and simulated values are fecal bacteria concentrations, all in colony forming units per 100 milliliters. USGS, U.S. Geological Survey; RWQCB, Regional Water Quality Control Board; OCWD, Orange County Water District. N/A, not applicable]

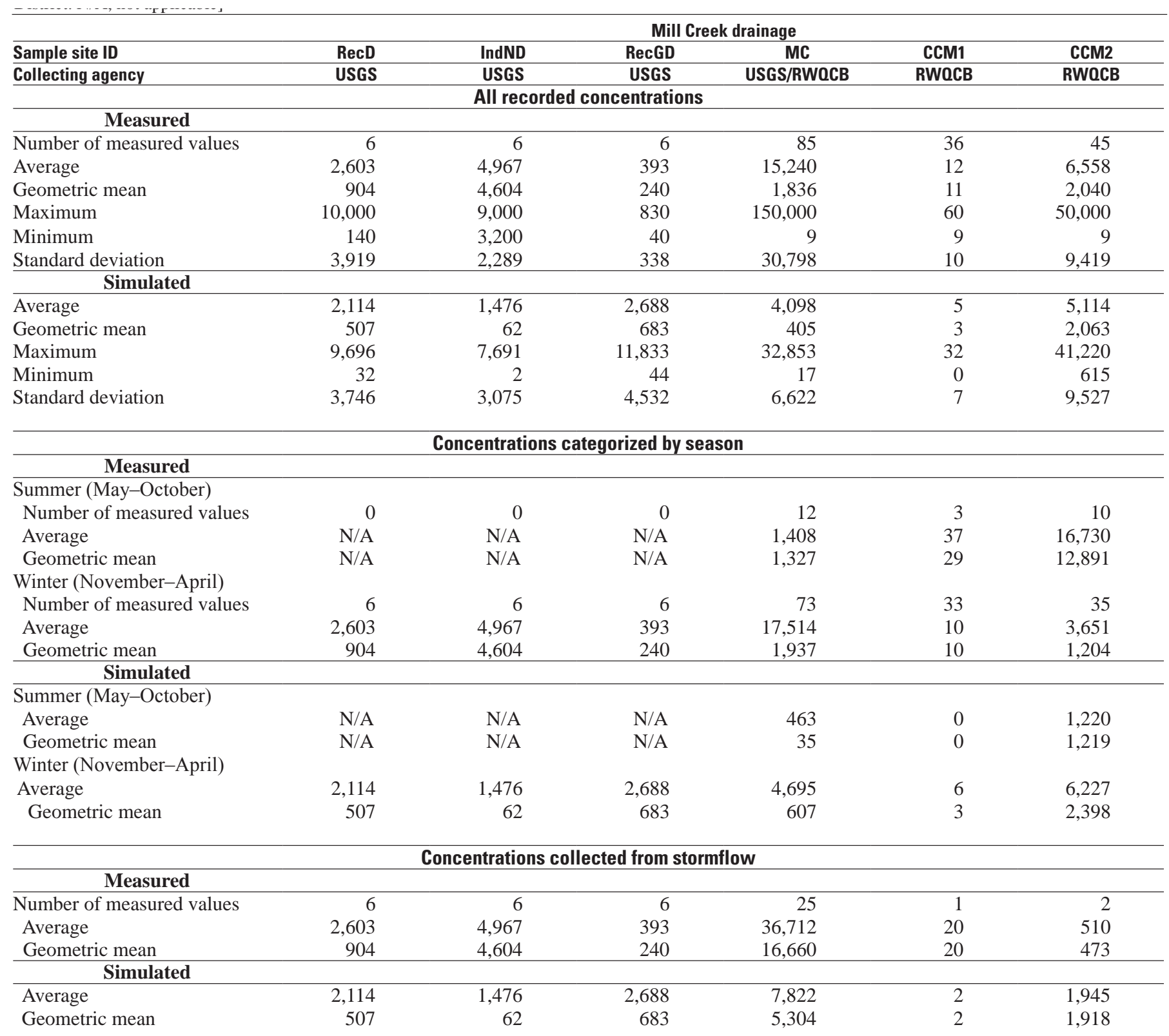


Table 12. Calibration summary of simulated fecal coliform concentrations and measured indicator bacteria concentrations for 18 sampling sites in the Chino Basin, California.-Continued

[Location of some sites on figure 2 (green). Measured values are indicator bacteria concentrations and simulated values are fecal bacteria concentrations, all in colony forming units per 100 milliliters. USGS, U.S. Geological Survey; RWQCB, Regional Water Quality Control Board; OCWD, Orange County Water District. N/A, not applicable]

\begin{tabular}{|c|c|c|c|c|c|c|c|c|c|c|c|c|}
\hline Sample site ID & \multicolumn{12}{|c|}{ Chino Creek drainage } \\
\hline Collecting agency & USGS & USGS & USGS & USGS & USGS & RWOCB & RWOCB & RWOCB & RWQCB & RWOCB & OCWD & OCWD \\
\hline \multicolumn{13}{|c|}{ All recorded concentrations } \\
\hline \multicolumn{13}{|l|}{ Measured } \\
\hline Average & 84,083 & 27,050 & 7,875 & 131 & 5,517 & 17,775 & 8,655 & 452,931 & 219 & 404 & 3,004 & 26,423 \\
\hline Geometric mean & 44,397 & 17,108 & 6,696 & 102 & 5,397 & 9,431 & 826 & 31,026 & 15 & 152 & 1,467 & 4,883 \\
\hline Maximum & 250,000 & 60,000 & 18,000 & 320 & 7,400 & 46,000 & 160,000 & $5,200,000$ & 9,400 & 8,200 & 6,750 & 117,000 \\
\hline \multicolumn{13}{|l|}{ Simulated } \\
\hline Average & 18,901 & 11,585 & 19,230 & 1,379 & 2,585 & 5,689 & 2,775 & 12,713 & 87 & 534 & 1,446 & 15,624 \\
\hline Geometric mean & 12,928 & 1,907 & 328 & 442 & 1,998 & 1,193 & 1,859 & 3,962 & 20 & 3 & 1,118 & 5,400 \\
\hline Maximum & 40,276 & 59,629 & 114,158 & 6,128 & 6,754 & 16,950 & 13,557 & 59,736 & 736 & 16,530 & 3,020 & 32,753 \\
\hline Minimum & 1,811 & 91 & 36 & 45 & 884 & 147 & 30 & 699 & 3 & 0 & 543 & 543 \\
\hline Number of measured values & 0 & 0 & 0 & 0 & 0 & 3 & 13 & 0 & 12 & 7 & 2 & 3 \\
\hline Average & N/A & N/A & N/A & N/A & N/A & 17,367 & 21,106 & N/A & 837 & 257 & 458 & 39,488 \\
\hline Geometric mean & N/A & N/A & N/A & N/A & N/A & 7,468 & 1,620 & N/A & 47 & 166 & 397 & 3,927 \\
\hline Winter (November-April) & & & & & & & & & & & & \\
\hline Number of measured values & 6 & 6 & & 6 & 6 & 1 & 37 & 13 & 36 & 35 & 2 & 2 \\
\hline Average & 84,083 & 27,050 & 7,875 & 131 & 5,517 & 19,000 & 4,281 & 452,931 & 13 & 434 & 5,550 & 6,825 \\
\hline Geometric mean & 44,397 & 17,108 & 6,696 & 102 & 5,397 & 19,000 & 652 & 31,026 & 10 & 150 & 5,419 & 6,769 \\
\hline \multicolumn{13}{|l|}{ Simulated } \\
\hline \multicolumn{13}{|l|}{ Summer (May-October) } \\
\hline Average & N/A & N/A & N/A & N/A & N/A & 1,936 & 1,515 & N/A & 4 & 0 & 562 & 5,551 \\
\hline Geometric mean & N/A & N/A & N/A & N/A & N/A & 493 & 936 & N/A & 3 & 0 & 561 & 1,697 \\
\hline Winter (November-April) & & & & & & & & & & & & \\
\hline \multicolumn{13}{|l|}{ Simulated } \\
\hline Average & 18,901 & 11,585 & 19,230 & 1,379 & 2,585 & 11,231 & 2,517 & 845 & 464 & N/A & 2,331 & 25,666 \\
\hline Geometric mean & 12,928 & 1,907 & 328 & 442 & 1,998 & 9,666 & 2,324 & 845 & 376 & N/A & 2,227 & 24,444 \\
\hline
\end{tabular}




\section{Model Application: Evaluation of Contribution to Bacteria Contamination on the Basis of Flow Process and Land Use}

The calibrated HSPF transport model was applied to evaluate the relative contributions to bacteria loading in streamflow from the various flow processes represented in the model and from the various land uses (table 13). The relative contributions were compared to the average bacteria loads for the calibrated model: the comparison was referred to as the base-case result. The objective of this application was to improve understanding of the potential downstream affects on water quality of the different non-point bacteria loading rates, washoff limits, decay coefficients, and the areas of the different land uses. The results were also used to evaluate differences between the effects of PERLND (pervious area) and IMPLND (impervious area) on flow and transport, as well as differences between storm flow and low flow conditions and between summer and winter flow conditions.

The simulation period for model application was calendar year 1985-2005. The period analyzed was 1988-2005, allowing for a 3-year model initialization period to minimize the effect of initial conditions on the analysis. As in the case of model calibration, the analysis excluded results for time steps for which the simulated hourly streamflow was less than $0.0005 \mathrm{ft}^{3} / \mathrm{s}$ because of the high uncertainty associated with HSPF transport results for the very low flows.

\section{8-2005 Simulation Results: Summary of Base Case}

Table 13 provides a summary of the 1988-2005 simulation results for 6 sites in the Chino Creek subbasin (table 13A) and 6 sites in the Mill Creek subbasin (table 13B). The simulation results were compiled for the base-case, and for all flow-process and land-use test cases, using (1) all simulated flows, (2) winter and (3) summer flows, (4) storm flows, and (5) low flows. Winter flows were defined by results for November through April for a given water year, and summer flows were defined by results for May through October. The flow limit used for separating low flows from storm flows was based on visual inspection of the flow hydrograph at each site. The results for all flows, storm flows, and low flows include the average, geometric mean, maximum, and minimum bacteria concentrations. The results for winter and summer flows include the average, maximum and geometric mean for bacteria concentrations.

The maximum hourly bacteria concentration for all 12 sites was about 2.7 million $\mathrm{cfu} / 100 \mathrm{~mL}$ for sample site D (table 13A). Sample site D, which primarily represents storm runoff from the mixed agricultural and intensive livestock land uses, had the highest simulated average bacteria concentration of 8,551 cfu/100 mL also. Other sites having relatively high simulated average bacteria levels (greater than 2,000 cfu/100 $\mathrm{mL}$ ) were USGS stream gage 11073360 (sample site CHIS), CCM2 (table 13B), and USGS stream gage 11073493. Simulated average bacteria concentration exceeded $200 \mathrm{cfu} / 100 \mathrm{~mL}$ at all sites in the central and southern parts of the Chino Basin. Average bacteria concentrations were less than $200 \mathrm{cfu} / 100$ $\mathrm{mL}$ at the 3 sites representing natural drainages: CCM1 (average of $6 \mathrm{cfu} / 100 \mathrm{~mL}$ ), IHC (average of $46 \mathrm{cfu} / 100 \mathrm{~mL}$ ), and San Antonio Dam outflow (average of $121 \mathrm{cfu} / 100 \mathrm{~mL}$ ). For all sites, the simulated geometric mean bacteria concentration was much lower than the simulated average concentration (by as much as 1 to 2 orders of magnitude). Minimum concentrations were also relatively low; from 0 at CCM1 and PPOC to 37 at sample site D. In general, the simulation results at all sites were characterized by high variances and highly skewed distributions.

Average winter bacteria concentrations were much higher than average summer bacteria concentrations at all sites, and average simulated streamflow was also higher in the winter at all sites. The greatest absolute difference between average winter and summer bacteria levels occurred at site D (winter average of 15,203 cfu/100 mL versus summer average of $1,997 \mathrm{cfu} / 100 \mathrm{~mL}$ ). The highest relative differences tended to occur at sites in the Chino Creek subbasin (Chino Creek outflow, PPOC, and IHC). Maximum hourly bacteria concentrations were highest during the winter at all sites except San Antonio Dam outflow, CCM2, and stream gage 11073495.

Average bacteria concentrations for storm flows were higher than average concentrations for low flows at all sites except stream gage 11073360 (sample site CHIS). Sample sites PPOC and D, downstream of the mixed agriculture and diaries land uses, had the highest storm flow average bacteria concentrations (73,321 cfu/100 mL for PPOC and 49,524 for D). The storm flow average and the maximum hourly bacteria concentrations in the Chino Creek outflow and the Mill Creek outflow were similar, but the storm flow geometric mean concentration of $280 \mathrm{cfu} / 100 \mathrm{~mL}$ in the Chino Creek outflow was much lower than the geometric mean of 3,531 cfu/100 mL for the Mill Creek outflow. This difference is due in part to the Orange County water transfers that affected the Chino Creek drainage but not the Mill Creek drainage. The Orange County water transfer inflows, which in this study were modeled as pristine water, have a much higher flow volume than the wastewater effluent inflows and are included in the storm flow results. These inflows cause a lot of dilution of contaminated water in Chino Creek. 
Table 13A. Summary of 1988-2005 simulation results and percent contribution to bacteria loading by flow process and land use for locations for the Chino Creek and San Antonio Canyon subbasins in the Chino Basin, California..

[ft $3 / \mathrm{s}$, cubic feet per second; cfu/ $100 \mathrm{~mL}$, colony forming units per 100 milliliters; $\%$, percent. The reported significant figures do not imply a level of accuracy attributed to the simulation results]

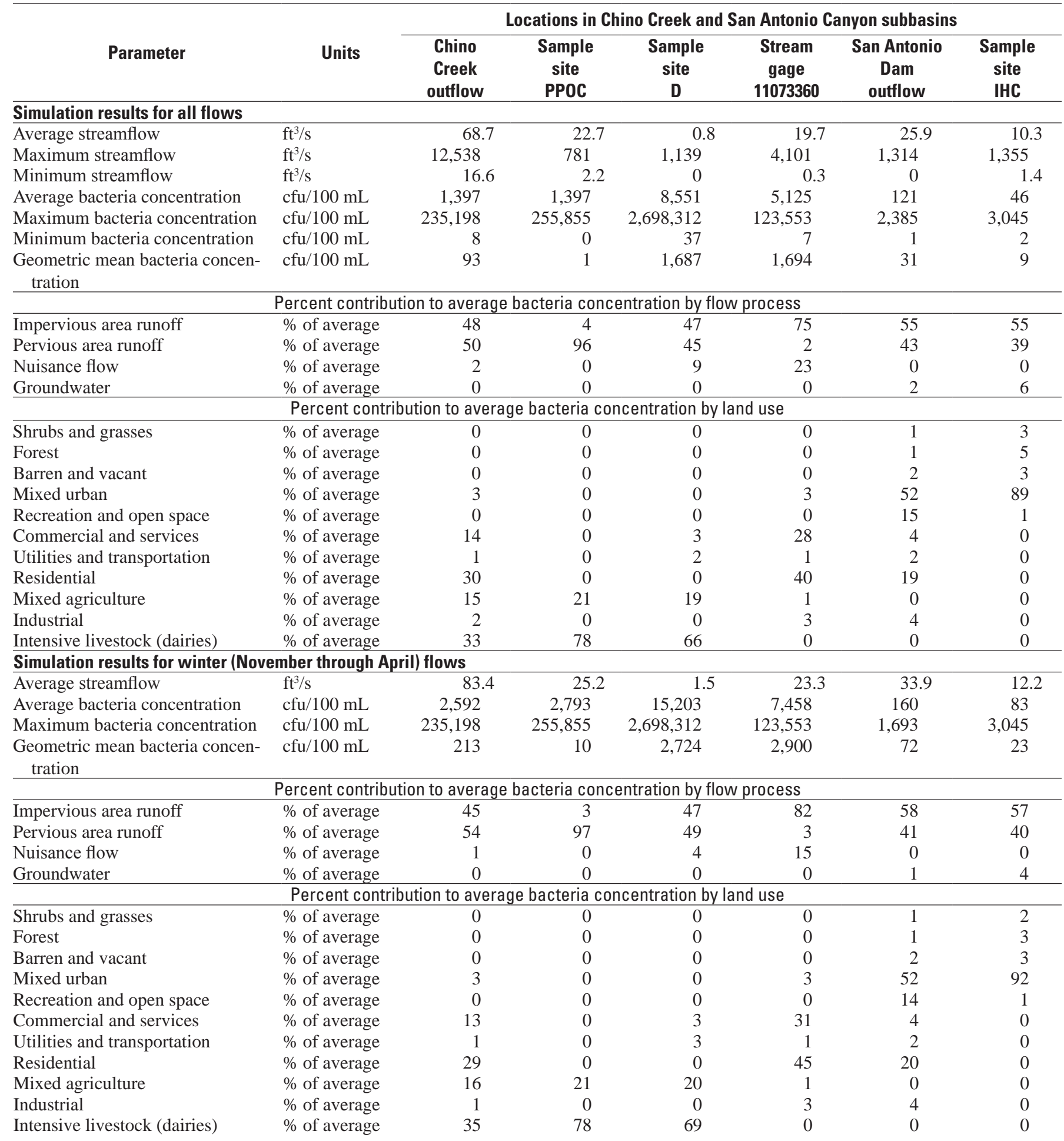


Table 13A. Summary of 1988-2005 simulation results and percent contribution to bacteria loading by flow process and land use for locations for the Chino Creek and San Antonio Canyon subbasins in the Chino Basin, California.-Continued

$\left[\mathrm{ft}^{3} / \mathrm{s}\right.$, cubic feet per second; cfu/100 mL, colony forming units per 100 milliliters; \%, percent. The reported significant figures do not imply a level of accuracy attributed to the simulation results]

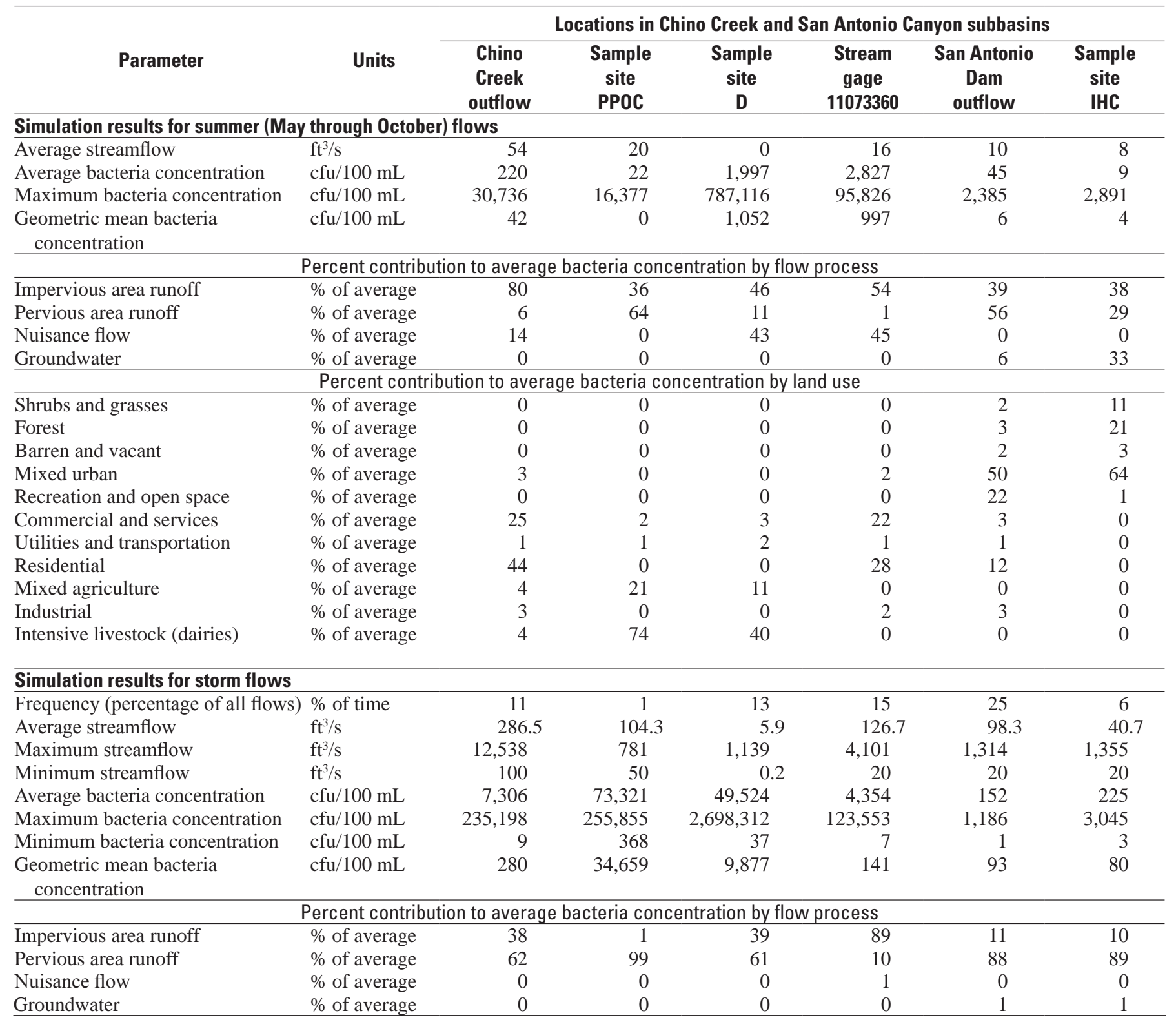


Table 13A. Summary of 1988-2005 simulation results and percent contribution to bacteria loading by flow process and land use for locations for the Chino Creek and San Antonio Canyon subbasins in the Chino Basin, California.-Continued

$\left[\mathrm{ft}^{3} / \mathrm{s}\right.$, cubic feet per second; cfu/100 mL, colony forming units per 100 milliliters; $\%$, percent. The reported significant figures do not imply a level of accuracy attributed to the simulation results]

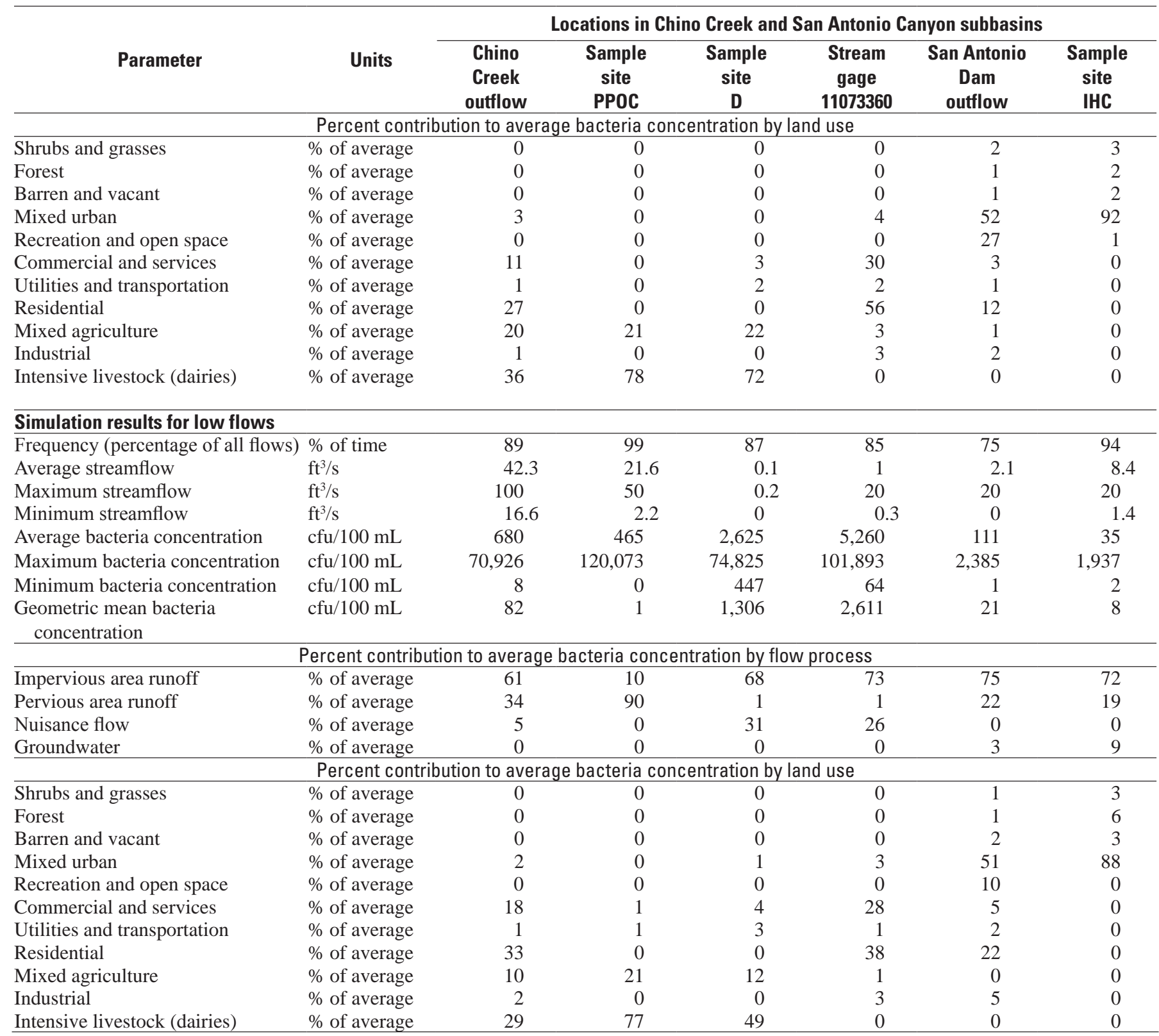


Table 13B. Summary of 1988-2005 simulation results and percent contribution to bacteria loading by flow process and land use for locations in the Mill Creek submodel in the Chino Basin, California.

[ft ${ }^{3} \mathrm{~s}$, cubic foot per second; cfu/100 mL, colony forming units per 100 milliliters; \%, percent. The reported significant figures do not imply a level of accuracy attributed to the simulation results]

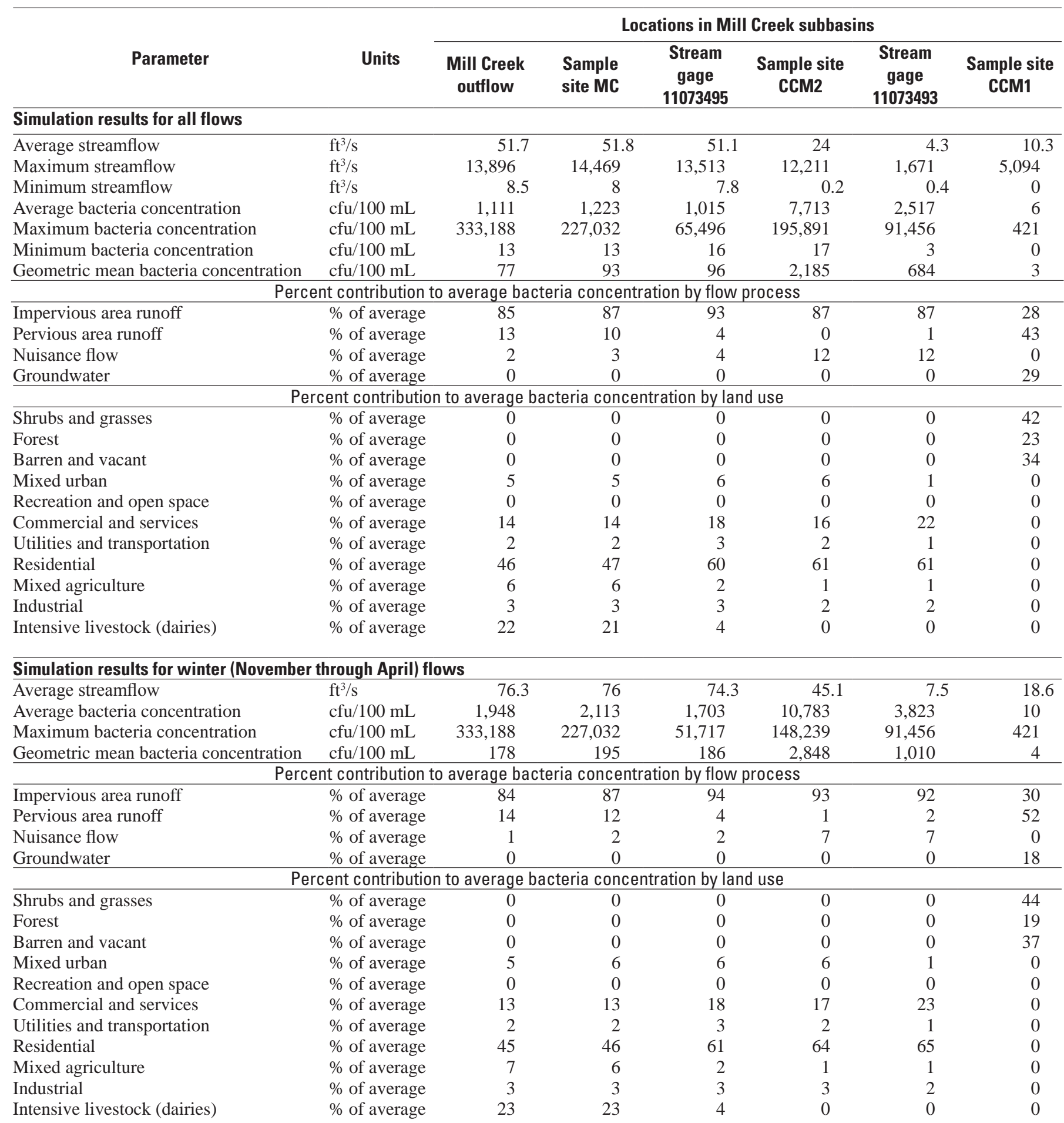


Table 13B. Summary of 1988-2005 simulation results and percent contribution to bacteria loading by flow process and land use for (B) locations in the Mill Creek submode in the Chino Basin, California.-Continued

[ft ${ }^{3} \mathrm{~s}$, cubic foot per second; cfu/ $100 \mathrm{~mL}$, colony forming units per 100 milliliters; $\%$, percent. The reported significant figures do not imply a level of accuracy attributed to the simulation results]

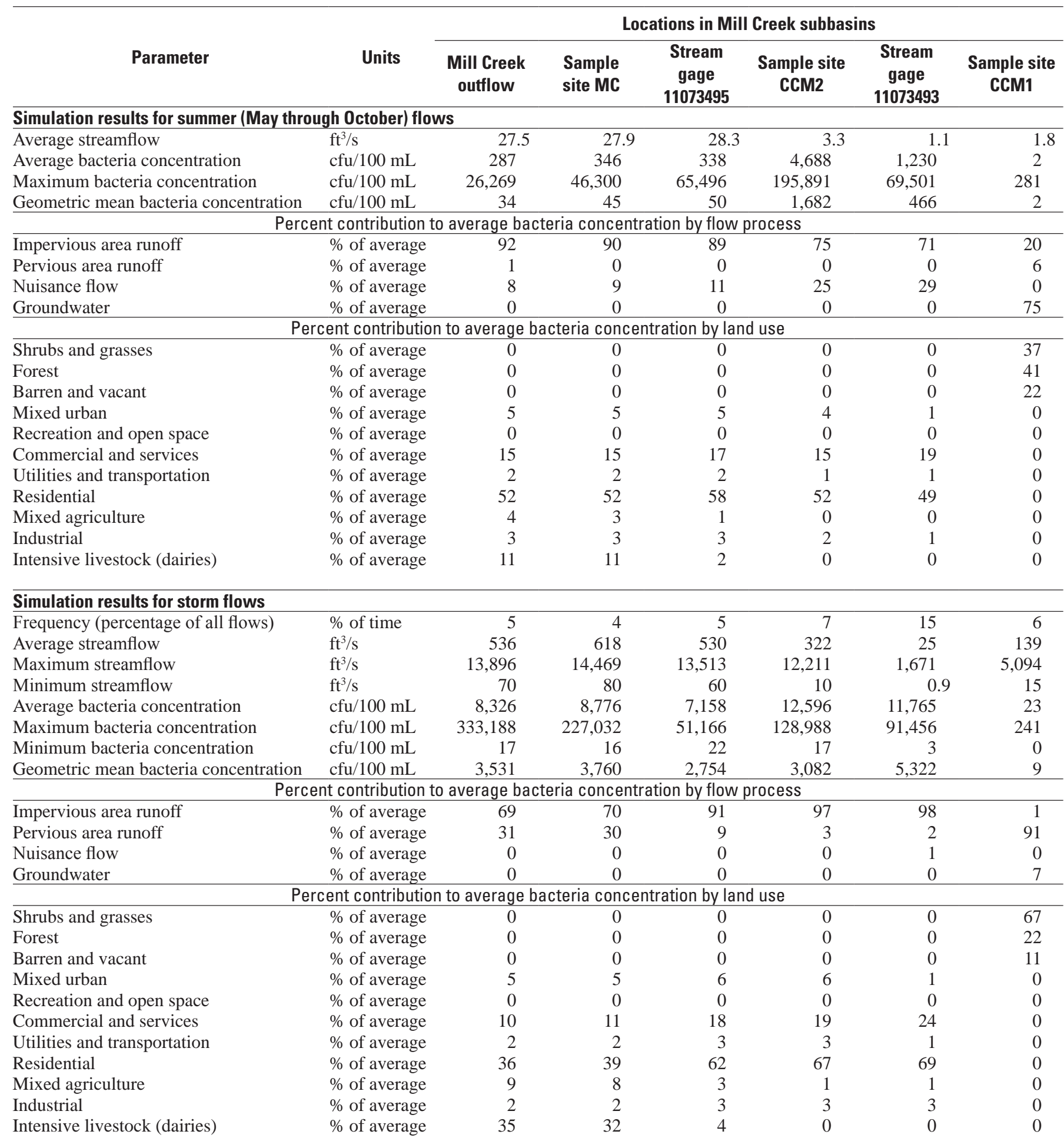


Table 13B. Summary of 1988-2005 simulation results and percent contribution to bacteria loading by flow process and land use for (B) locations in the Mill Creek submode in the Chino Basin, California.-Continued

[ $\mathrm{ft}^{3} \mathrm{~s}$, cubic foot per second; cfu/ $100 \mathrm{~mL}$, colony forming units per 100 milliliters; \%, percent. The reported significant figures do not imply a level of accuracy attributed to the simulation results]

\begin{tabular}{|c|c|c|c|c|c|c|c|}
\hline \multirow[b]{2}{*}{ Parameter } & \multirow[b]{2}{*}{ Units } & \multicolumn{6}{|c|}{ Locations in Mill Creek subbasins } \\
\hline & & $\begin{array}{c}\text { Mill Creek } \\
\text { outflow }\end{array}$ & $\begin{array}{l}\text { Sample } \\
\text { site MC }\end{array}$ & $\begin{array}{c}\text { Stream } \\
\text { gage } \\
11073495\end{array}$ & $\begin{array}{c}\text { Sample site } \\
\text { CCM2 }\end{array}$ & $\begin{array}{c}\text { Stream } \\
\text { gage } \\
11073493\end{array}$ & $\begin{array}{l}\text { Sample site } \\
\text { CCM1 }\end{array}$ \\
\hline \multicolumn{8}{|l|}{ Simulation results for low flows } \\
\hline Frequency (percentage of all flows) & $\%$ of time & 94.9 & 95.7 & 95 & 92.7 & 84.7 & 93.7 \\
\hline Average streamflow & $\mathrm{ft}^{3} / \mathrm{s}$ & 25.9 & 26.3 & 26.1 & 0.7 & 0.5 & 1.6 \\
\hline Maximum streamflow & $\mathrm{ft}^{3} / \mathrm{s}$ & 70 & 80 & 60 & 10 & 0.9 & 15 \\
\hline Average bacteria concentration & $\mathrm{cfu} / 100 \mathrm{~mL}$ & 726 & 884 & 695 & 7,331 & 845 & 5 \\
\hline Maximum bacteria concentration & $\mathrm{cfu} / 100 \mathrm{~mL}$ & 25,368 & 66,086 & 65,496 & 195,891 & 29,176 & 421 \\
\hline Minimum bacteria concentration & cfu/100 mL & 13 & 13 & 16 & 106 & 243 & 0 \\
\hline Geometric mean bacteria concentration & $\mathrm{cfu} / 100 \mathrm{~mL}$ & 63 & 79 & 81 & 2,127 & 472 & 3 \\
\hline \multicolumn{8}{|c|}{ Percent contribution to average bacteria concentration by flow process } \\
\hline Impervious area runoff & \% of average & 96 & 95 & 94 & 86 & 59 & 36 \\
\hline \multicolumn{8}{|c|}{ Percent contribution to average bacteria concentration by land use } \\
\hline Shrubs and grasses & \% of average & 0 & 0 & 0 & 0 & 0 & 35 \\
\hline Forest & $\%$ of average & 0 & 0 & 0 & 0 & 0 & 24 \\
\hline Barren and vacant & $\%$ of average & 0 & 0 & 0 & 0 & 0 & 41 \\
\hline Mixed urban & $\%$ of average & 5 & 6 & 5 & 6 & 0 & 0 \\
\hline Recreation and open space & $\%$ of average & 0 & 0 & 0 & 0 & 0 & 0 \\
\hline Commercial and services & $\%$ of average & 16 & 15 & 18 & 16 & 16 & 0 \\
\hline Utilities and transportation & $\%$ of average & 2 & 2 & 3 & 2 & 1 & 0 \\
\hline Residential & $\%$ of average & 52 & 50 & 60 & 60 & 41 & 0 \\
\hline Mixed agriculture & $\%$ of average & 4 & 4 & 2 & 1 & 0 & 0 \\
\hline Industrial & $\%$ of average & 3 & 3 & 3 & 2 & 1 & 0 \\
\hline Intensive livestock (dairies) & $\%$ of average & 14 & 16 & 4 & 0 & 0 & 0 \\
\hline
\end{tabular}

\section{Flow-Process Contributions to Bacteria Contamination}

The relative contribution to bacteria contamination was evaluated for 4 different flow processes represented by the HSPF transport model: (1) impervious-area runoff, (2) pervious-area runoff, (3) groundwater discharge, and (4) nuisance flow. The relative contribution by a given flow process was simulated by setting the parameters defining transport and bacteria loading for the other three processes to zero. For example, to simulate the relative contribution from impervious-area runoff, SQO, ACQOP, and SQOLIM were set to zero for all PERLNDs, and bacteria loading for nuisance inflow was set to zero (nuisance inflows were modeled as uncontaminated). To simulate the effect of pervious-area runoff, bacteria loading for nuisance inflow was set to zero, SQO, ACQOP, and SQOLIM were set to zero for all IMPLNDs, and the SQO, ACQOP, and SQOLIM for PERLNDs were left unchanged (equal to the calibrated base-case parameter values). Parameters controlling ground-water bacteria loading (throughflow and deep ground-water discharge) for PERLNDs were also set to zero for evaluating pervious-area runoff. To evaluate ground-water contributions, bacteria loading for nuisance flow was set to zero, SQO, ACQOP, and SQOLIM for both IMPLNDs and PERLNDs were set to zero (eliminating bacteria loading for overland flow), and the parameters defining bacteria loading for throughflow and deep ground-water discharge were left unchanged. To evaluate nuisance flow contributions, SQO ACQOP, and SQOLIM for IMPLNDs and PERLNDs were set to zero, and ground-water bacteria loading was set to zero. In all cases, the decay coefficients in RCHRES were left unchanged. 


\section{Contribution of Flow Processes for Selected Storms}

Simulation results from the modified model were used to compare bacteria concentrations in terms of the four flowprocess contributions for the February 2004 storms sampled at site D (fig. 20) and for the winter storms in 2004 and 2005 sampled at the Mill Creek outflow (fig. 21). The simulated hourly bacteria concentrations for the two storms sampled at site D (February 2 and February 22-23) were primarily affected by impervious area runoff (fig. 20). Ground water did not contribute to bacteria contamination at this site; nuisance flow contributions were diluted during the storm flows, but substantial during low flow conditions. Nuisance flow contributions between storm flows were approximately $1,000 \mathrm{cfu} / 100 \mathrm{~mL}$. Runoff from pervious areas made no contribution to the February 2 storm because pervious areas were not generating runoff, and only minor amounts came from pervious areas during the February 22-23 storm. However, during the next storm on February 26 (not sampled for bacteria), runoff from pervious areas contributed much more than runoff from impervious areas to the simulated bacteria concentrations (by approximately 2 orders of magnitude). Runoff from the next smaller storm on March 2 also included substantial bacteria loading from pervious area runoff, but slightly less than from the impervious areas.

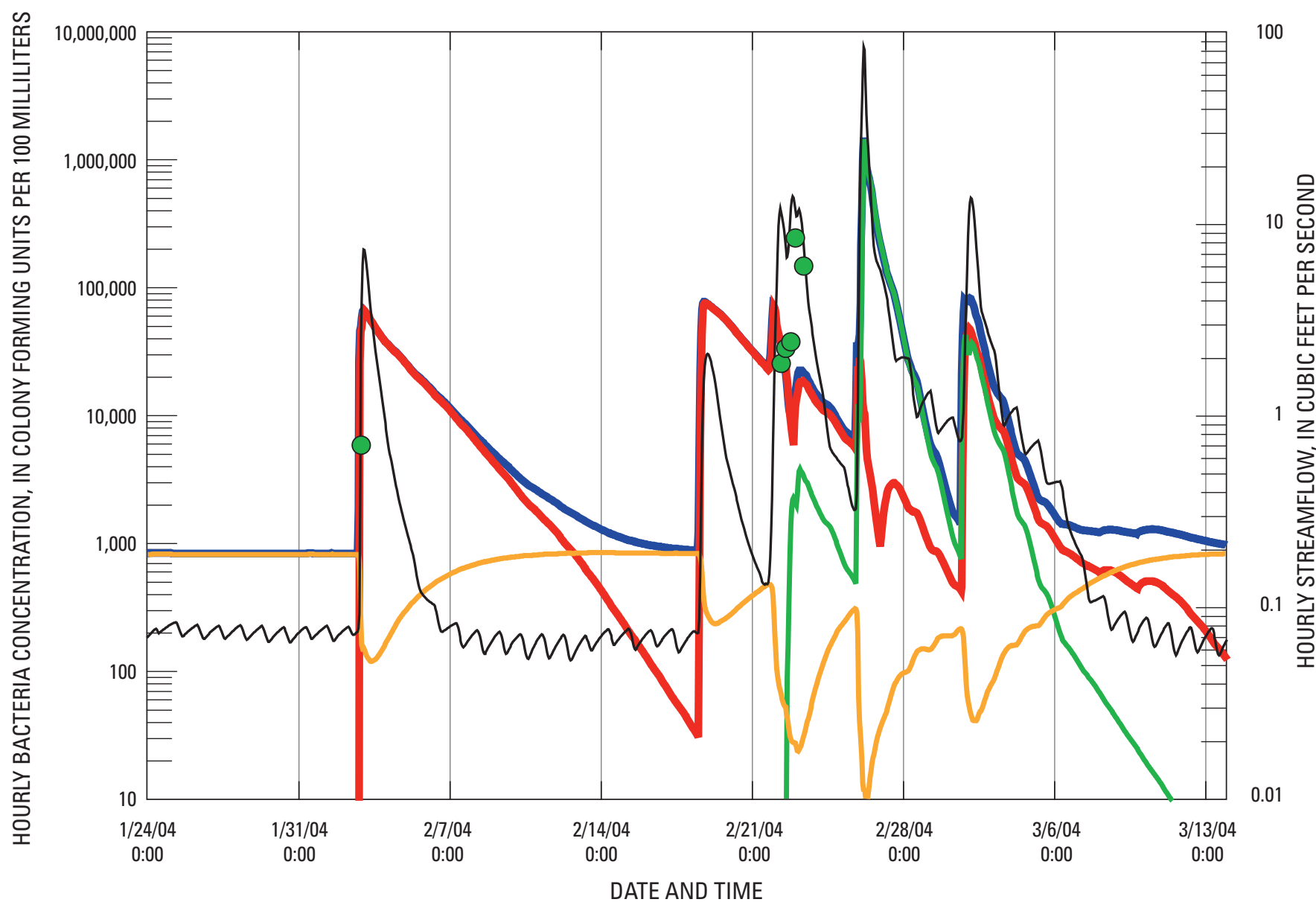

\section{EXPLANATION}
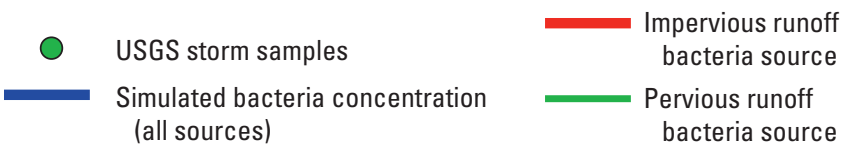

Nuisance flow bacteria source

Simulated streamflow

Figure 20. Simulated hourly bacteria concentrations affected by different flow processes during storms in February 2004 at sample site $\mathrm{D}$ in the Chino Basin, California. 


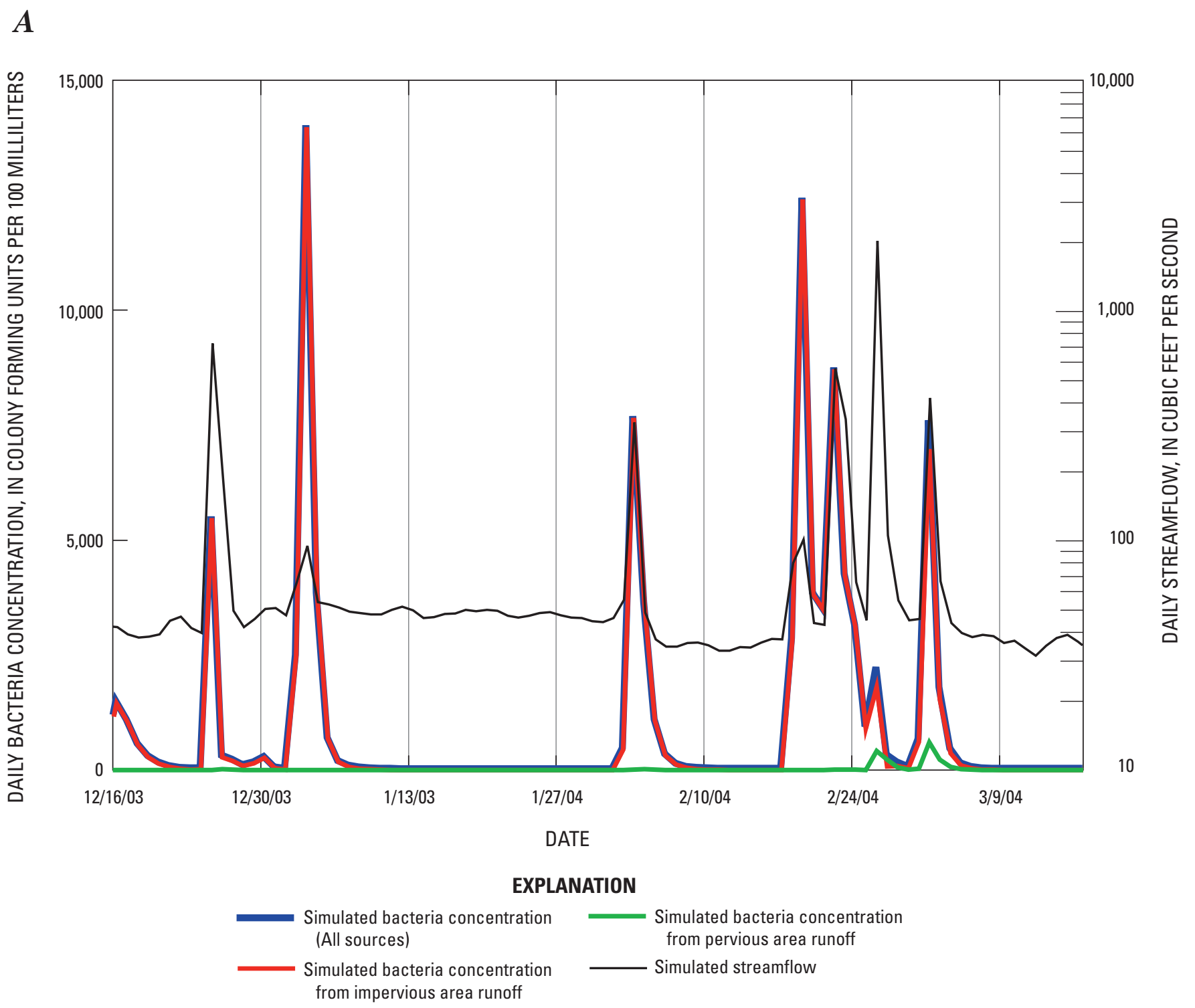

Figure 21. Simulated daily bacteria concentrations affected by different flow processes for $A$, storms during December-March, water-year 2004, at Mill Creek outflow, and B, storms during December-March, water-year 2005, at Mill Creek outflow in the Chino Basin, California.

Simulated daily bacteria concentrations at Mill Creek outflow were mostly from impervious area runoff for the 12/6/2003 to 3/9/2004 storm period (fig. 21A). Only a small amount of bacteria loading from pervious-area runoff occurred during the 2/26/2004 and 3/2/2004 storms. In contrast, the contribution to bacteria loading from pervious-area runoff was much greater than the impervious area contribution for the larger storms of 2005 (fig. 21B). Bacteria concentrations from impervious area runoff were usually elevated during earlier storms in a storm sequence and during the time represented by the rising limb of the storm hydrograph. Bacteria concentrations from pervious-area runoff were usually elevated during the latter part of a storm sequence, after the ground had become saturated. Bacteria concentration from pervious runoff reached a peak during or after the hydrograph peak for the Mill Creek outflow. 
48,000

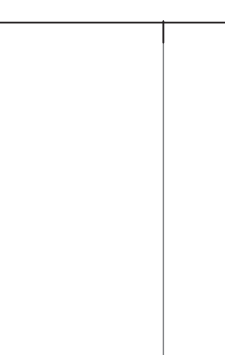

32,000

.

$12 / 1 / 0$

$12 / 1 / 04$

$12 / 15 / 04$

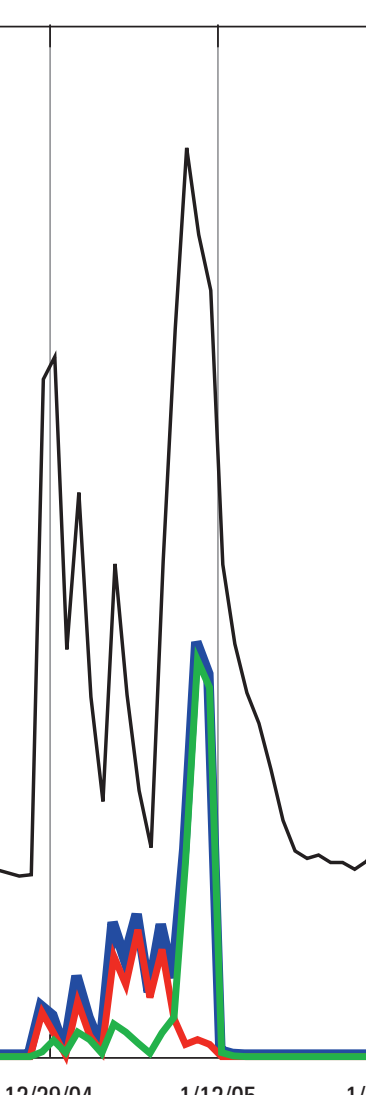

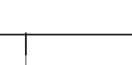

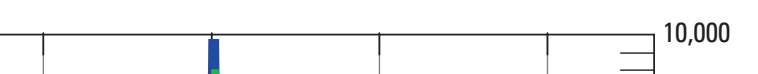

10,000

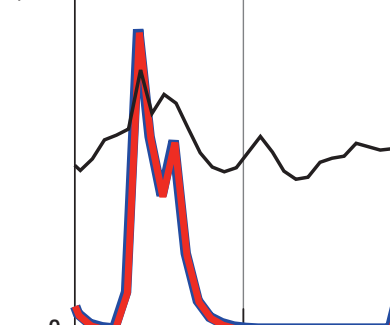

DATE

EXPLANATION

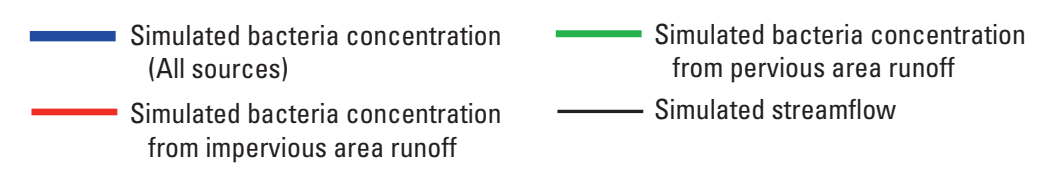

Figure 21. Continued.

\section{Concentration Duration Analysis for Flow- Process Contributions}

Results for the flow processes were compared using concentration-duration curves indicating the percentage of time bacteria concentrations were exceeded for simulated 1988-2005 hourly fecal coliform concentrations at 7 sites: San Antonio Dam outflow, sample site D, sample site PPOC, Chino Creek outflow, site CCM1, sample site CCM2, and Mill Creek outflow (fig. 22). For most locations within and downstream of the urbanized areas in the Chino Basin, maximum bacteria levels were simulated in response to runoff from pervious areas, but the percentage of time that pervious area runoff was the dominant bacteria source was relatively low. Pervious-area runoff was the dominant source of maximum simulated bacteria concentrations at San Antonio Dam outflow (fig. 22A), sample site D (fig. 22B), sample site PPOC (fig. 22C), Chino Creek outflow (fig. 22D), and Mill Creek outflow (fig. 22G). However, the percentage of time during which pervious-area runoff was the dominant bacteria source was less than about 4 percent at site PPOC, less than about 1 percent at site $\mathrm{D}$ and Chino Creek outflow, and less then about 0.15 percent at Mill Creek outflow. For the two sites representing natural conditions, CCM1 (fig. 22E) and San Antonio Dam outflow (fig. 22A), pervious-area runoff was an important source to the total bacteria load much more often than for the locations within and downstream of the urban areas. 


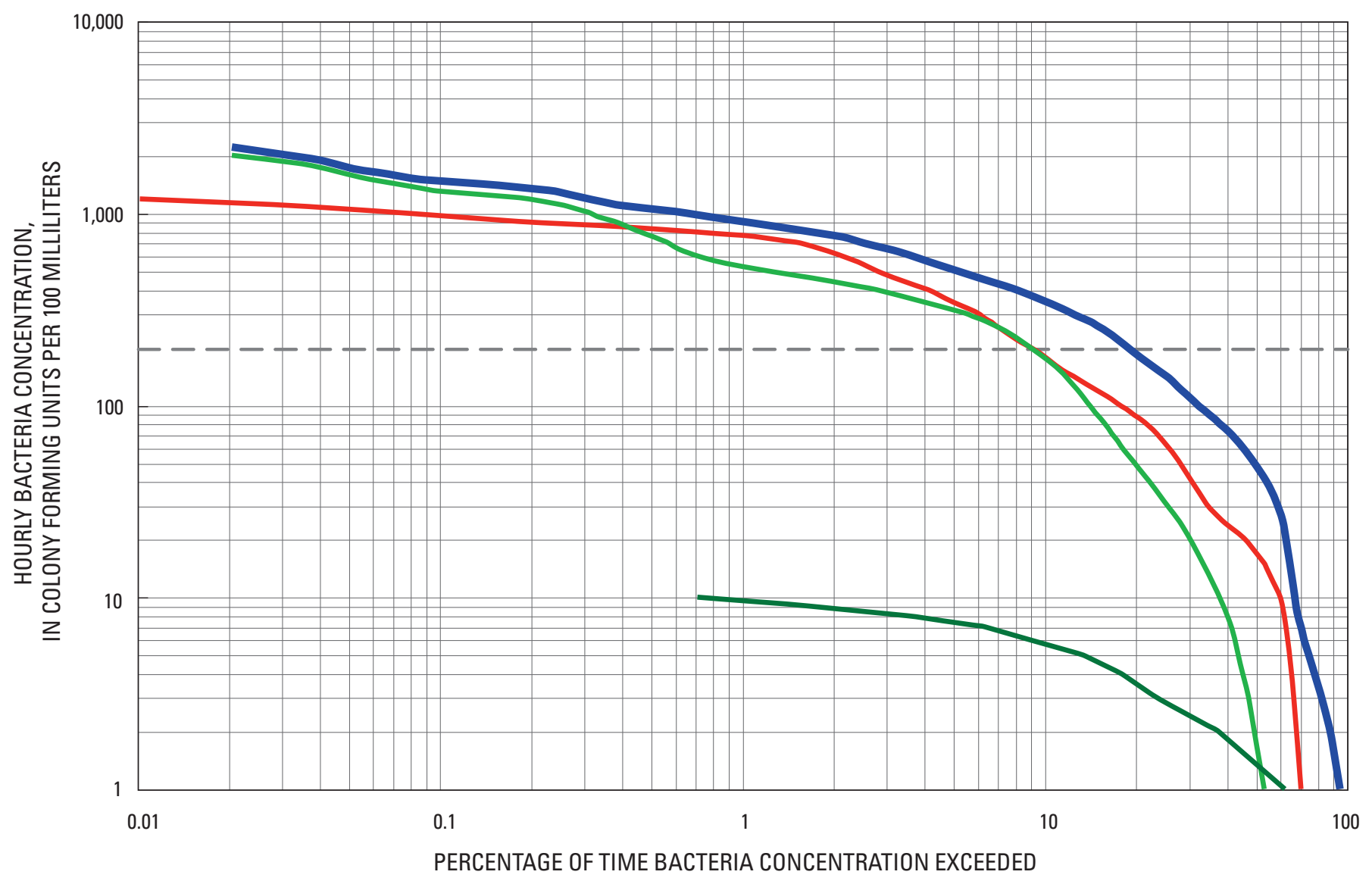

PERCENTAGE OF TIME BACTERIA CONCENTRATION EXCEEDED

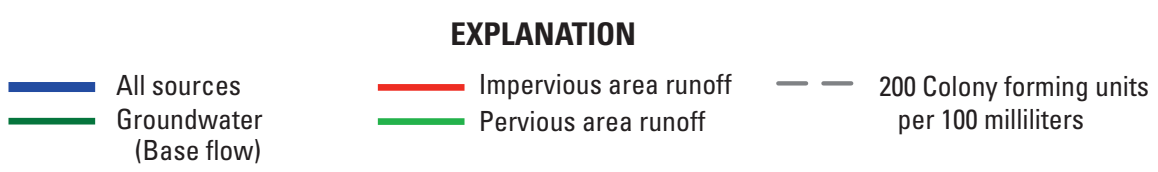

Figure 22. Concentration durations for simulated hourly bacteria concentrations affected by different flow processes at $A$, San Antonio Dam outflow, B, sample site D, C, sample site PPOC (Prado Park Lake outflow), D, Chino Creek outflow, E, sample site CCM1, (F) sample site CCM2, and G, Mill Creek outflow for water-years 1988-2005 in the Chino Basin, California.

The concentration-duration analysis for CCM2 indicates that pervious area runoff is a minor to insignificant source of bacteria loading at all times compared to loading from impervious areas and nuisance flows (fig. 22F). Nuisance-flow contributions downstream of urban areas but upstream of wastewater treatment facilities significantly affected water quality; bacteria concentrations from nuisance flow were greater than $1,000 \mathrm{cfu} / 100 \mathrm{~mL}$ about 60 percent of the time and greater than $200 \mathrm{cfu} / 100 \mathrm{~mL}$ about 90 percent of the time. Although the model incorporated a very simplified representation of nuisance flow using an assumed inflow concentration, the general concept of contaminated nuisance flow is consistent with the measured bacteria data. Results for sample site D (fig. 22B) also indicate important contributions to total bacteria loading from nuisance flow; bacteria concentrations from nuisance flow was greater than $900 \mathrm{cfu} / 100 \mathrm{~mL}$ for about 70 percent of the time, and greater than $200 \mathrm{cfu} / 100 \mathrm{~mL}$ for about 90 percent of the time. However, the model may not represent the flow volume component of the nuisance flow accurately at this site because an assumed inflow rate per unit area of urban and agricultural land uses in the entire model area was used to determine the magnitude of the nuisance inflow.

Nuisance-flow contributions to bacteria contamination was significant for sites located within urbanized areas (where the nuisance flow was generated) and upstream of inflows from the wastewater treatment facilities. This was especially true for low flow conditions when stream flow was essentially equivalent to the nuisance inflows. 
$\boldsymbol{B}$

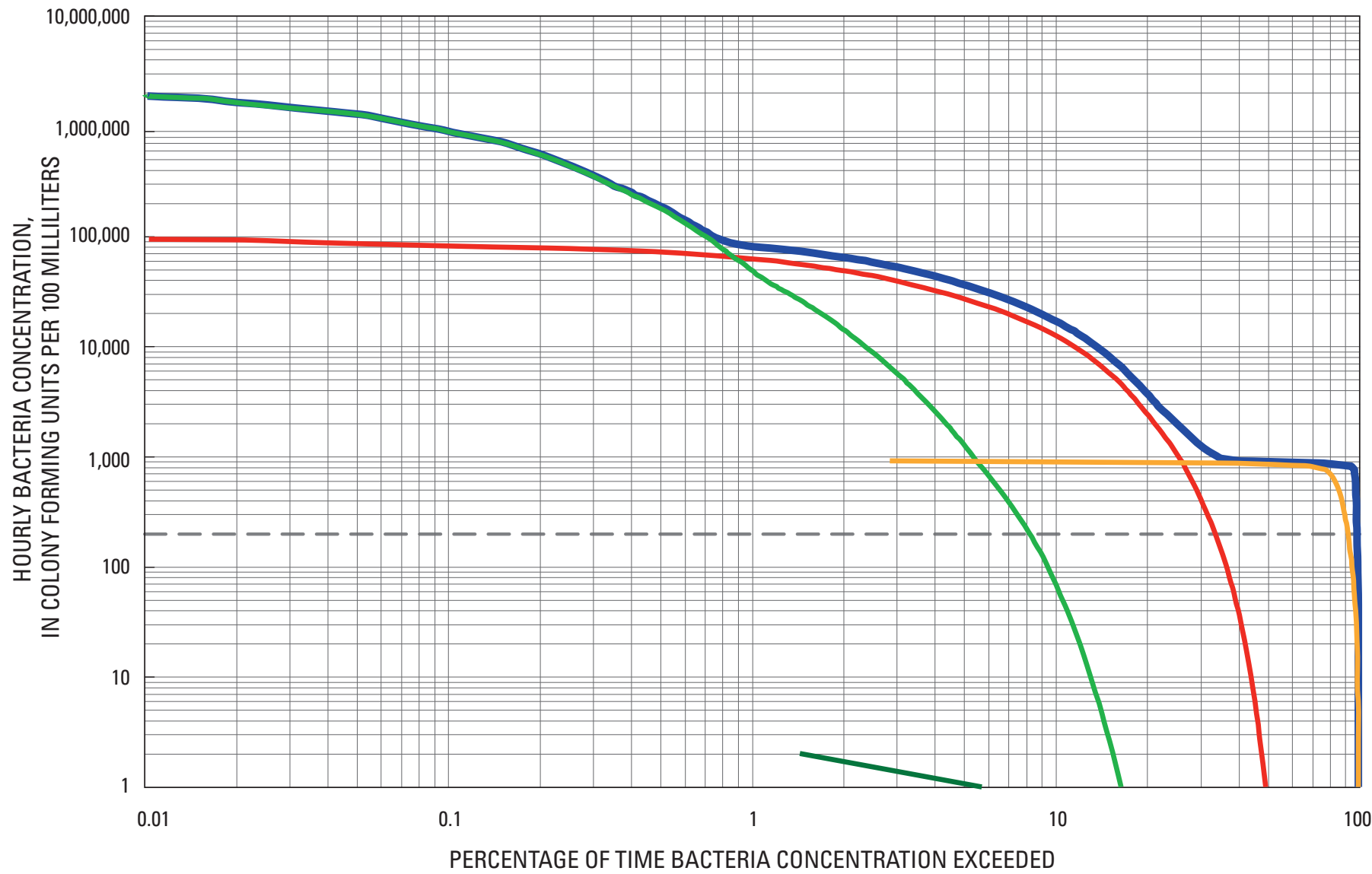

Figure 22. Continued.

\section{Flow Processes Contributions to Average Bacteria Concentrations}

The average simulated bacteria concentrations for all flows at the 12 sites used to summarize model results (table 13) indicates that impervious-area runoff was the dominant bacteria source for the central and lower parts of the Mill Creek subbasin (from 85 to 93 percent of the average bacteria loading for the base-case simulation). In contrast, results for the Chino Creek subbasin indicate higher site-tosite variation in the dominant flow process contributing to bacteria contamination. Pervious-area runoff is responsible for 96 percent of the average bacteria loading at site PPOC, but only 45 percent at site $\mathrm{D}$. This difference occurs because the flows having a high percentage of impervious area bacteria loading tend to be low flows that are easily diluted by the RP-1 discharges into Prado Park Lake, upstream of PPOC. In addition, bacteria decay (die-off) is maximized in Prado Park Lake because of the average residence time of water in the lake (as opposed to the shorter residence time of water stored in the main channels). Only the larger storms result in high bacteria concentrations in Prado Park Lake outflow, and these storms tend to be dominated by bacteria loading from pervious-area runoff. 
C

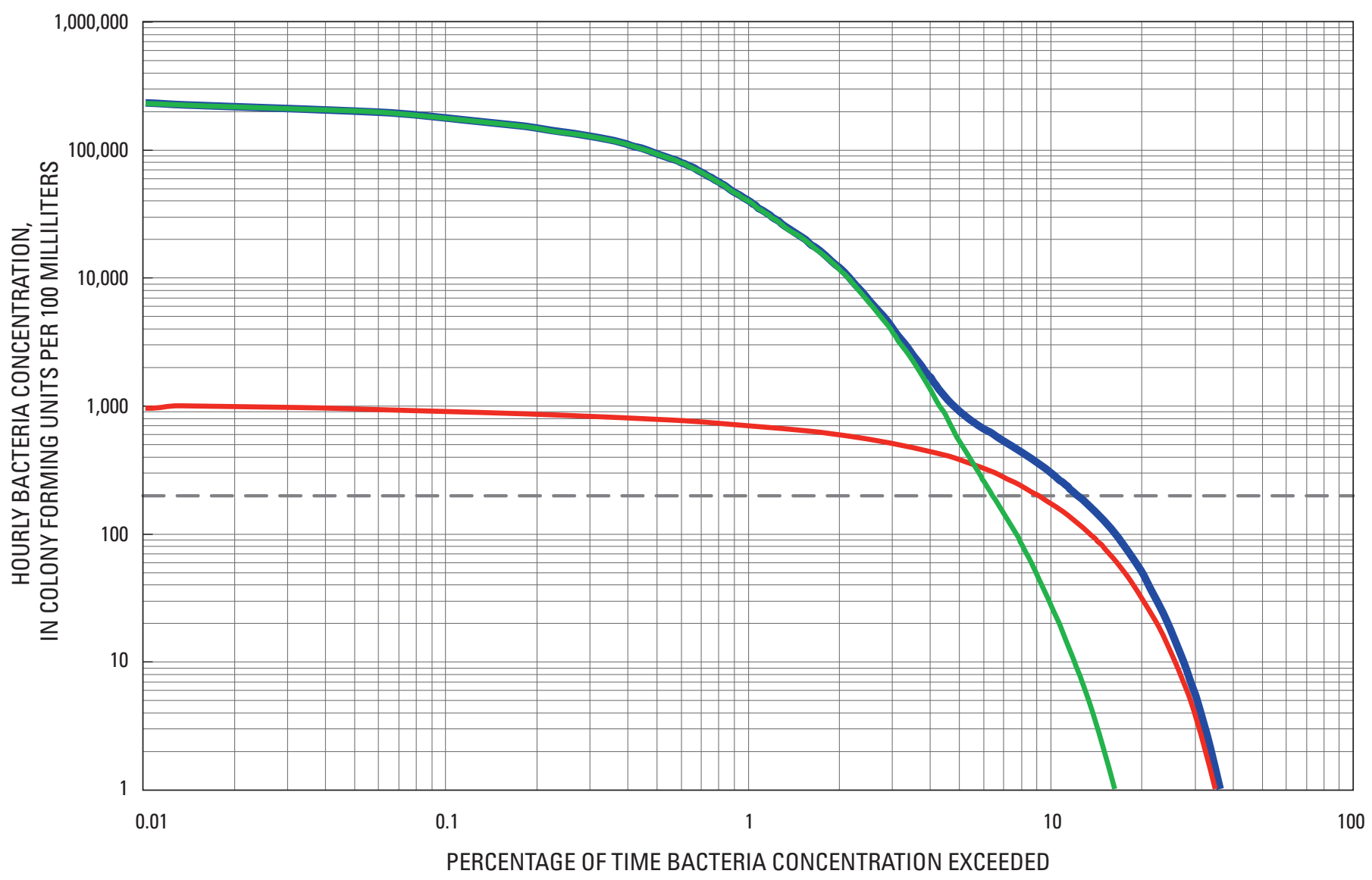

EXPLANATION

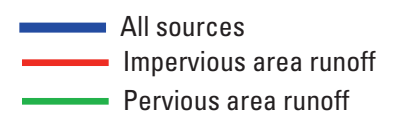

- 200 Colony forming units

per 100 milliliters

Figure 22. Continued.

Overall, pervious area runoff resulted in the highest peak concentrations because pervious areas account for a larger percentage of total upstream land area and because loading rates were estimated to be higher for pervious areas than for the urban and agricultural (including dairy) land uses. The overall comparison of simulation results indicates that impervious area runoff was the main source of the storm runoff and subsequent bacteria washoff in the Chino Basin because impervious area runoff occurs much more often than pervious area runoff. Runoff from pervious areas is generated only during the larger storms when the precipitation intensity exceeds the soil infiltration capacity or during storm periods characterized by a high frequency of storms that saturate soils.
Impervious-area runoff contributions were slightly higher than pervious-area contributions for the IHC and San Antonio Canyon outflow sites, even though these sites are fed by drainages that represent mostly natural conditions. The land-use map identified a small fraction of the total area within the San Antonio Canyon drainage, including the area directly upstream of the IHC site, as urban land (for example, the road in San Antonio Canyon, low density residential, and campground or picnic areas are included as urban land). In contrast, the drainage upstream of the CCM1 site contained only the 3 natural land-use categories; shrubs and grasses, forests, and barren areas. Simulation results at CCM1 indicated that pervious area runoff was the dominant contributor to the average bacteria loading. 

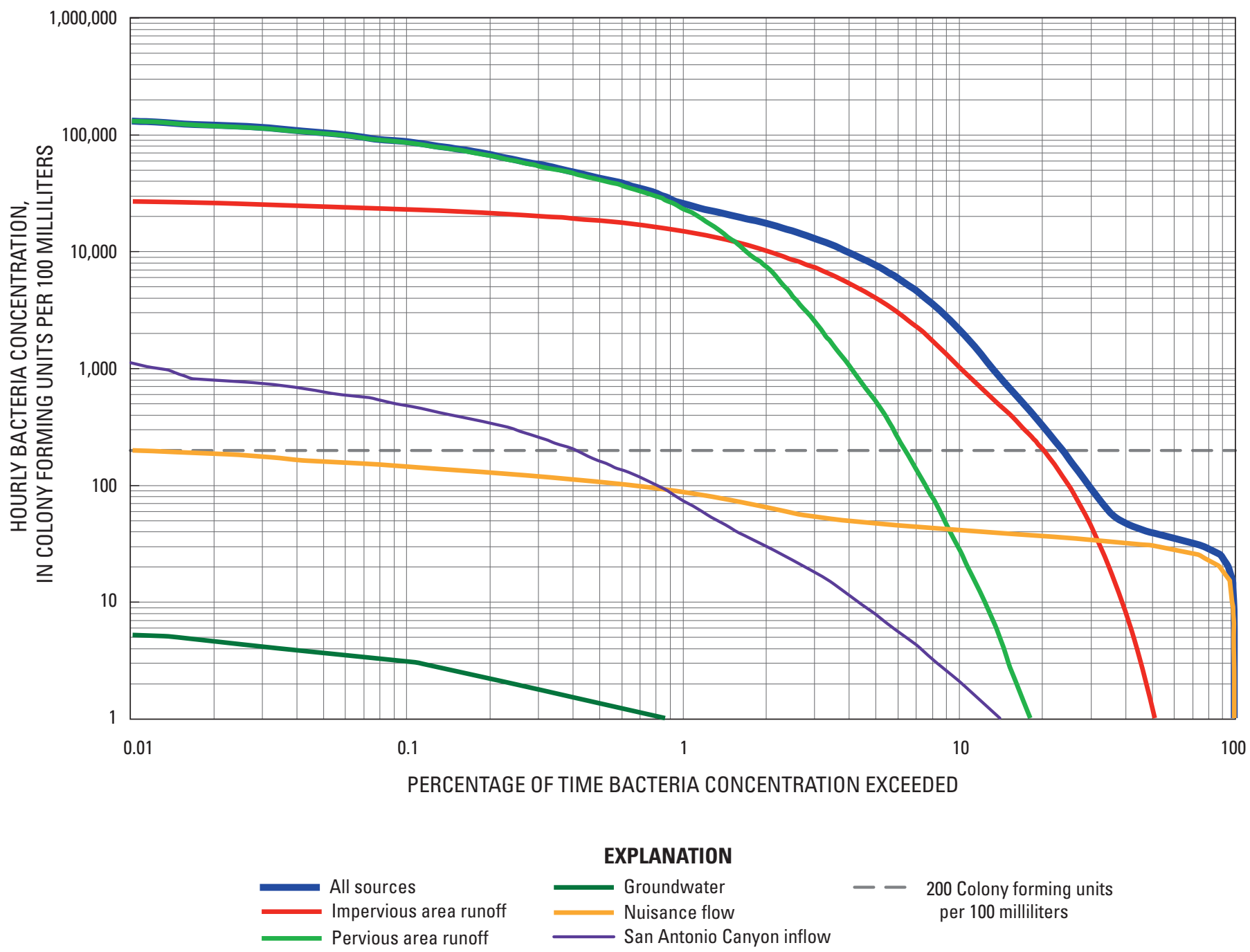

Figure 22. Continued.

Sites indicating a substantial (greater than 10 percent) contribution to average bacteria concentrations from nuisance flow were stream gage 11073493 and CCM2 in the Mill Creek subbasin and stream gage 11073360 (sample site CHIS) in the Chino Creek subbasin (table 13). All sites were strongly affected by runoff from the highly urbanized central part of the Chino Basin and were upstream of the wastewater effluent inflows that dilute the high concentrations of the nuisance flows. Nuisance flow contributions were highest during summer flows and low flows at most sites. The highest nuisance flow contribution during summer was 45 percent at stream gage 11073360 (sample site CHIS), and the highest low flow contribution was 41 percent at stream gage 11073493 .
Only the CCM1 site indicated a substantial groundwater contribution (29 percent) to average bacteria concentrations based on all flows combined. There was also some small ground-water contribution to the sites in San Antonio Canyon: 6 percent at IHC and 2 percent at San Antonio Dam outflow. Groundwater contribution to average bacteria concentrations at all other sites was zero. Ground-water contributions were much higher during summer flows; 75 percent at CCM1, 33 percent at site IHC, and 6 percent at San Antonio Canyon outflow. Groundwater contributions were only slightly higher during low flows; 35 percent at CCM1, 9 percent at IHC, and 3 percent at San Antonio Dam outflow. 
$\boldsymbol{E}$
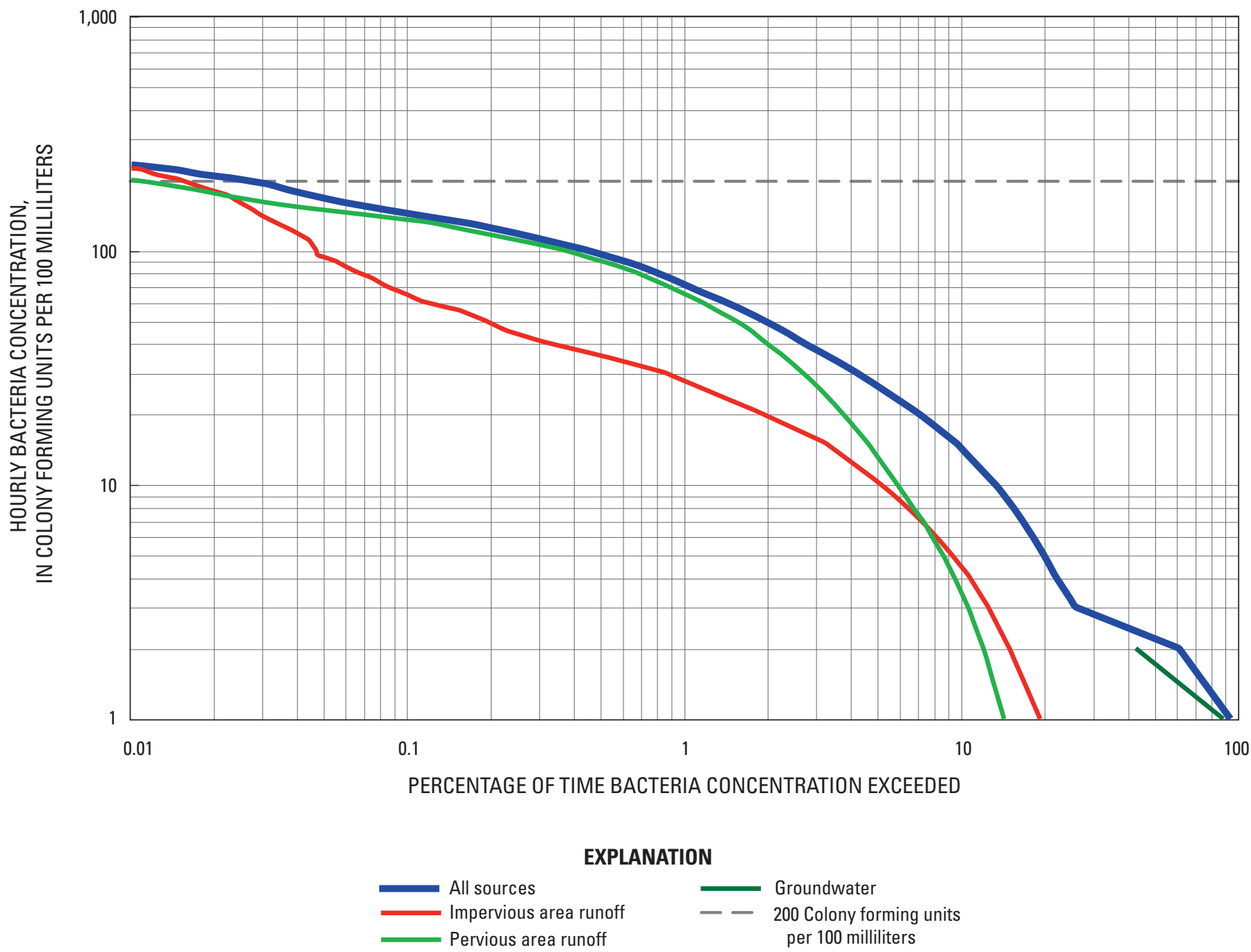

Figure 22. Continued.

\section{Evaluation of Source Area Contribution on the Basis of Land Use}

Bacteria loading from a single land-use area was simulated by setting the SQO, ACQOP, and SQOLIM parameters to zero for all other land uses except for the land use being simulated (the calibrated base line parameters were left unchanged for this land use). In addition, nuisance flow was simulated as pristine water (nuisance inflows did not include bacteria) in order to fully isolate the effect of a single land use on the average bacteria loading. The parameters defining bacteria loading for ground water for a given PERLND were left unchanged for the PERLND being simulated. These simulations were repeated for all land-use types except for water and wetlands (water and wetlands is a significant land use only for the Prado Dam subbasin), and the results from all simulations, including the base-case (baseline) simulation for all land uses, were compared. The evaluations were based on the simulation results for calendar years 1988-2005, allowing for a 3 year model ramp up (simulations were started on 1/1/1985) to mitigate the effects of uncertainty in initial conditions. 
$\boldsymbol{F}$

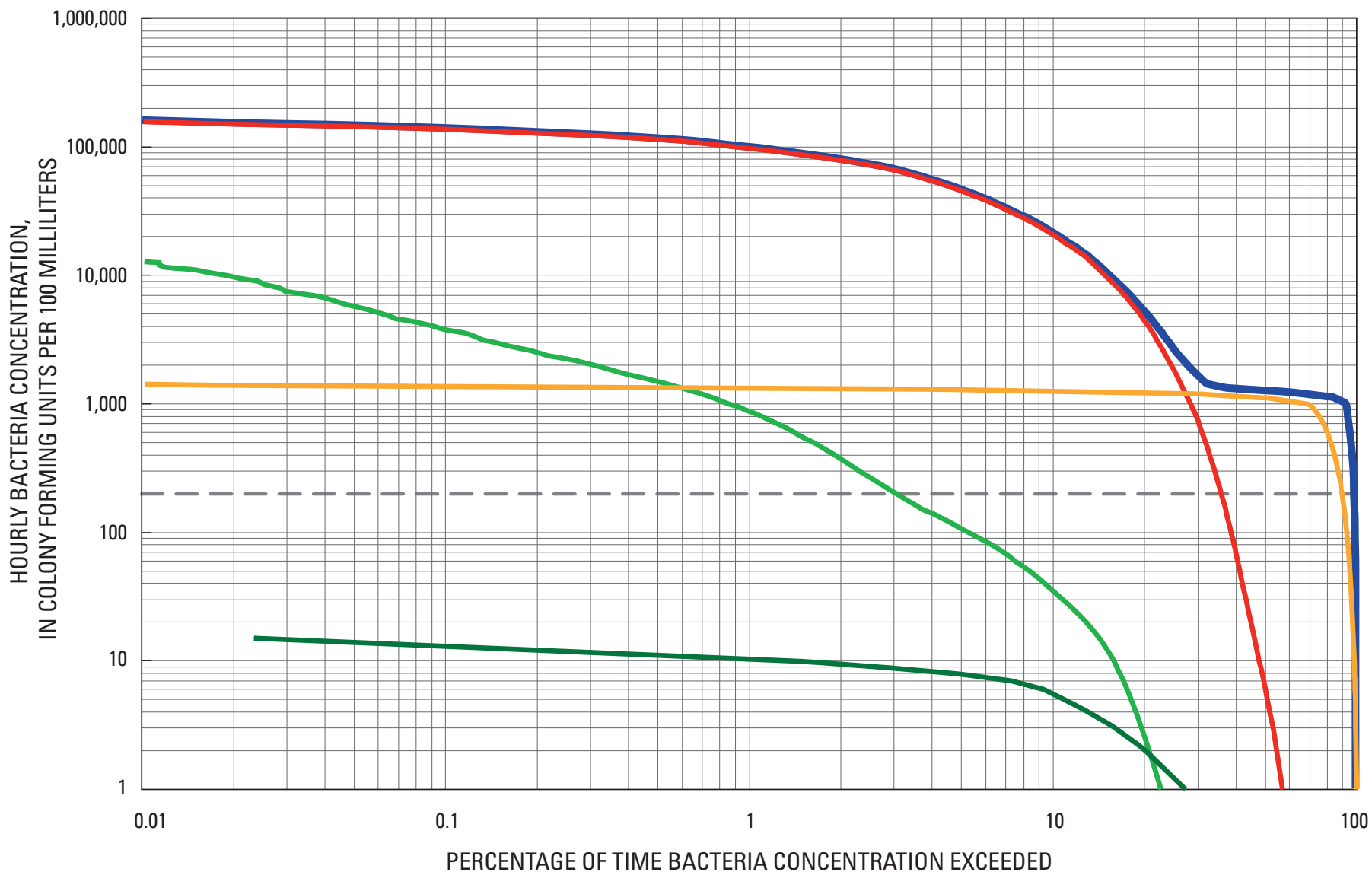

Figure 22. Continued.

\section{Land-Use Contributions to Bacteria Concentrations for Selected Storms}

Simulated hourly bacteria concentrations affected by various land uses and by storms during 2/21/2004-2/28/2004 and 2/17/2005-2/25/2005 at Mill Creek and Chino Creek outflow were compared (fig. 23). Runoff from residential land use contributed the most to the total bacteria loading at both locations during the 2/22/2004-2/23/2004 storm (fig. 23A). Runoff from commercial and services land use also contributed substantially to the downstream bacteria concentrations at Chino Creek outflow. Impervious-area runoff from dairies contributed the most to bacteria concentrations at the Mill Creek site, but only a minor amount to the Chino Creek outflow site. In both cases, the bacteria contamination was caused by impervious-area runoff. Most of the bacteria were washed off of the impervious surfaces during the first hydrograph peak on $2 / 22 / 2004$. Runoff during the second hydrograph peak had much less bacteria to washoff and diluted bacteria concentration in downstream reaches. Bacteria concentration increased during the falling limb of the hydrograph because the delayed inflows from the upstream reaches were not diluted. 


\section{$G$}
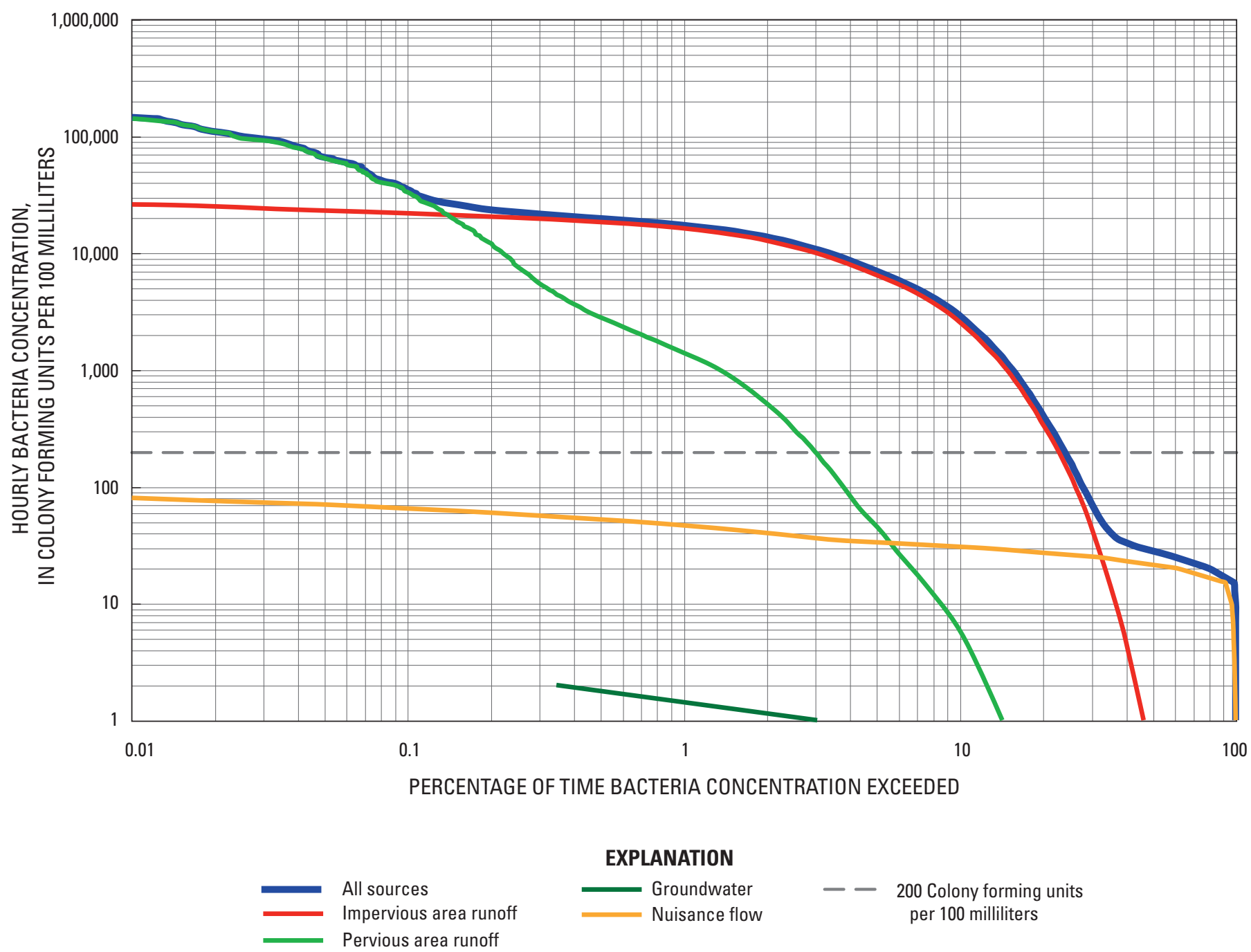

Figure 22. Continued.

Contaminated runoff from mixed agriculture and intensive livestock was a much higher amount of total bacteria loading for the 2/26/2004 storm than for the 2/22/2004 storm at Chino Creek outflow (fig. 23A) The maximum bacteria concentration for both was about $10,000 \mathrm{cfu} / 100 \mathrm{~mL}$, only slightly more than that for residential land use. Results for the 2/26/2004 storm at Mill Creek were different because the contamination was caused by impervious area runoff (fig. 23B), whereas the high bacteria concentrations simulated for Chino Creek included a substantial contribution from pervious area runoff.
The results for the wetter $2 / 17 / 2005-2 / 25 / 2005$ storms show a much higher contribution from the mixed agriculture and intensive livestock land uses because pervious-area runoff was the dominant runoff source during these storms and the modeled non-point source area loading was much higher for mixed agriculture and intensive livestock than for all other land uses. At Chino Creek outflow, mixed agriculture runoff caused the highest peak bacteria concentrations, about $38,000 \mathrm{cfu} / 100 \mathrm{~mL}$, and residential runoff also contributed substantially to the total bacteria loading (fig. 23C). In contrast, mixed agriculture and residential runoff provided only 


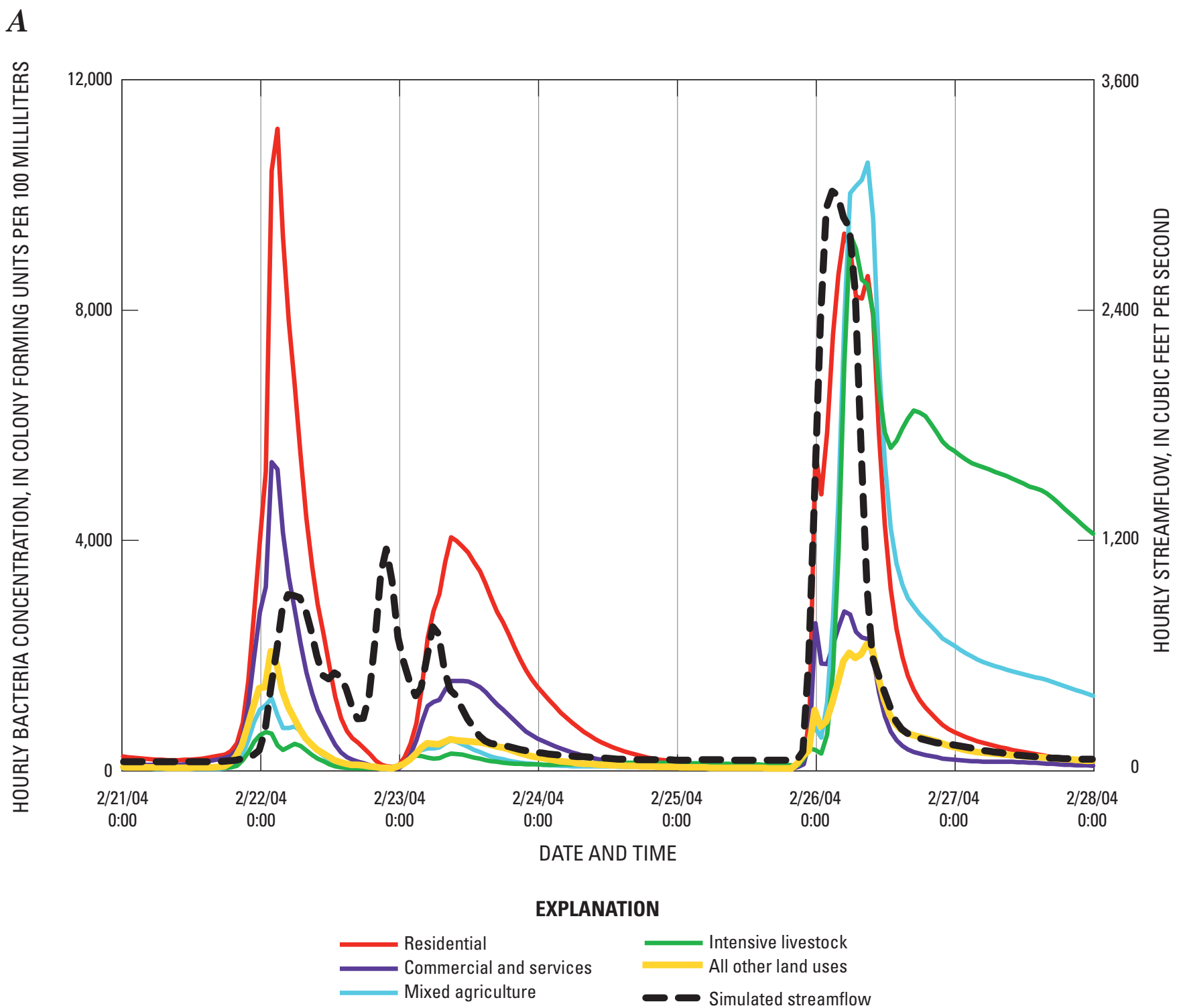

Figure 23. Land-use contributions to simulated bacteria concentrations at $A$, Chino Creek outflow for storms in February 2004, $B$, Mill Creek outflow for storms in February 2004, C, Chino Creek outflow for storms in February 2005, and D, Mill Creek outflow for storms in February 2005 in the Chino Basin, California.

minor contributions to the bacteria loading compared with runoff from dairies at the Mill Creek site (fig. 23D). Perviousarea runoff from intensive livestock land use areas upstream of Mill Creek outflow caused peak hourly bacteria concentrations of about 140,000 cfu/100 mL during the end of the storm sequence in response to saturated soil conditions. In general, the primary sources of bacteria contamination at Chino Creek and Mill Creek outflow were areas used for residential, mixed agriculture, and intensive livestock land-use areas that produced runoff during the storm periods.
Hourly concentration-duration (or exceedance) curves for land-use sources were analyzed using simulation results for 7 sites: San Antonio Dam outflow, sample site D, sample site PPOC (Prado Park Lake outflow), Chino Creek outflow, sample site CCM1, sample site CCM2, and Mill Creek outflow (fig. 24). The concentration-duration curve shows the proportion of all hourly fecal coliform concentrations exceeding a given value. Simulation results for each separate land use were compared to the base case concentration-duration curves (upper black line) at all sites to evaluate the relative 


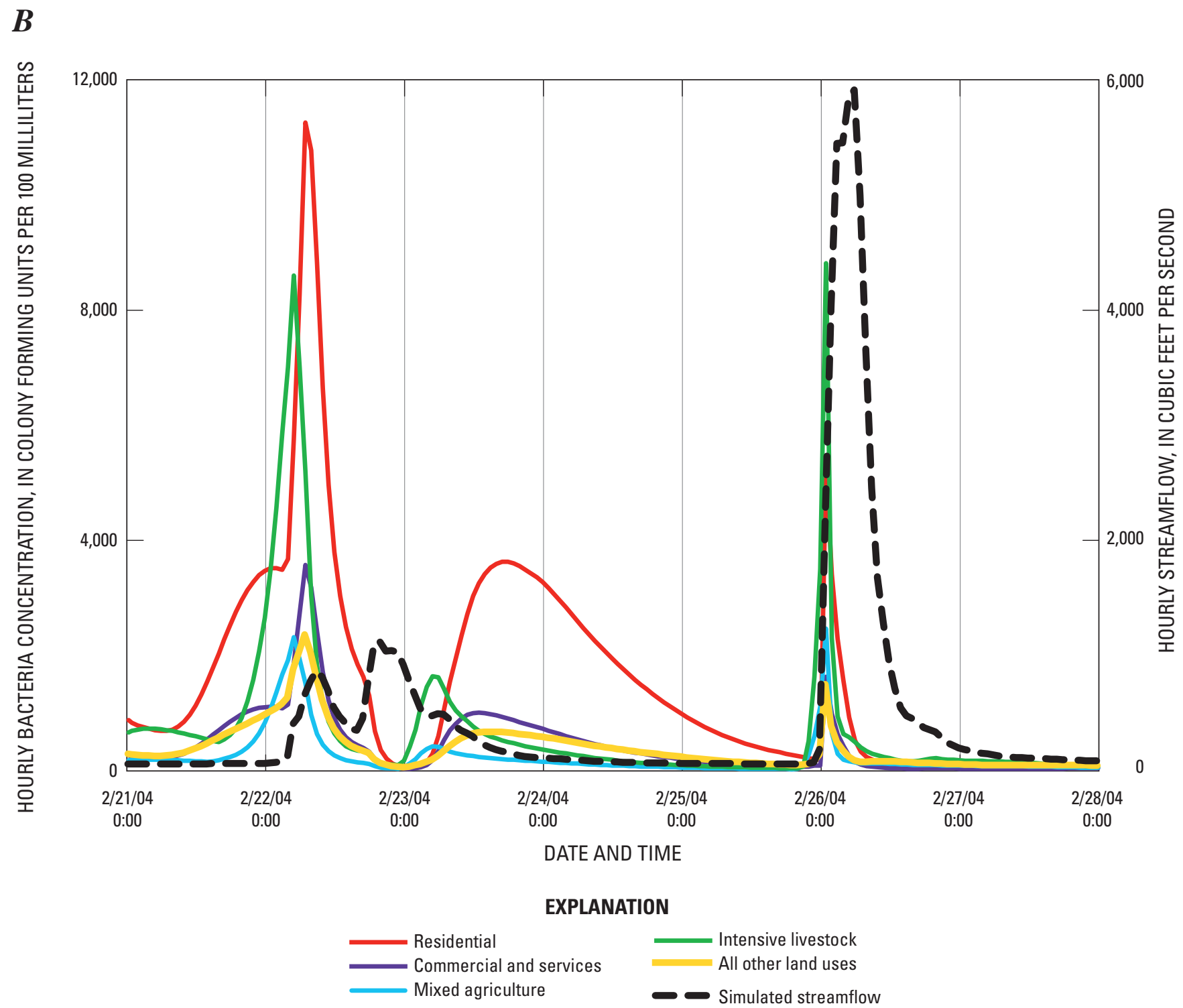

Figure 23. Continued.

contributions to bacteria contamination. At San Antonio Dam outflow, the primary sources of bacteria contamination were the mixed-urban, residential, and recreational and open-space land uses (fig. 24A). The natural land uses at San Antonio Dam outflow provided only minor contributions to total bacteria loading relative to those provided by the urban land uses, even though the natural areas were a much greater fraction of the total upstream area. At sample site D, intensive livestock, mixed agriculture, and transportation and utilities provided the greatest contribution to bacteria contamination; the concentrations from intensive livestock land-use areas are above
2,000 cfu/100 mL (fig. 24B) approximately 22 percent of the time. Most of the time, nuisance flow was the primary source of bacteria levels higher than $200 \mathrm{cfu} / 100 \mathrm{~mL}$ at site D. At Prado Park Lake outflow, contamination was primarily caused by runoff from intensive livestock and mixed agriculture land-use areas (fig. 24C), but concentrations from intensive livestock exceeded the $200 \mathrm{cfu} / 100 \mathrm{~mL}$ limit only about 12 percent of the time because of dilution from RP-1 discharges into Prado Park Lake and the longer residence time of water in Prado Park Lake. In contrast to results for the Prado 


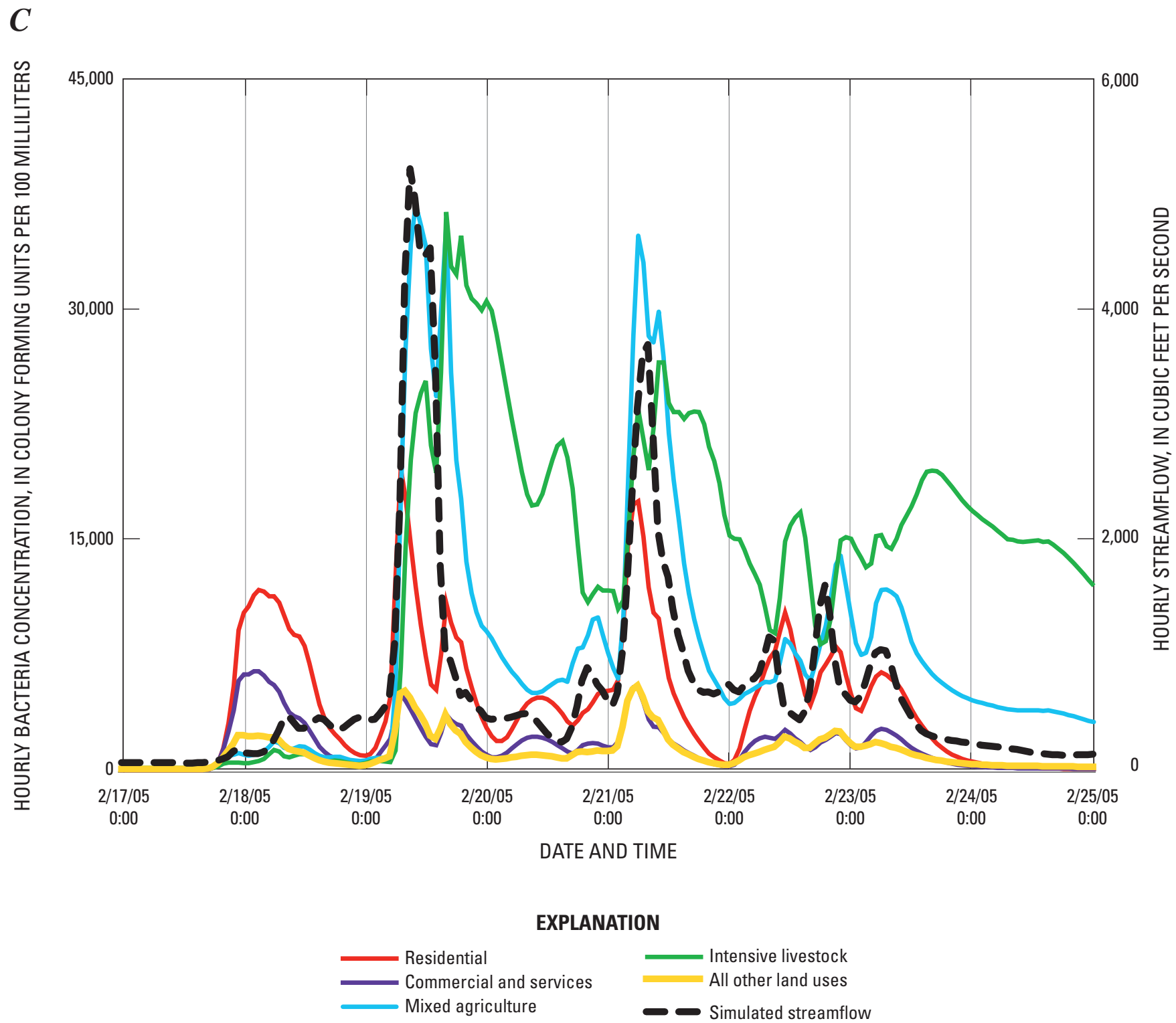

Figure 23. Continued.

Park Lake drainage, results for Chino Creek outflow indicate that runoff from residential land use contributes a higher relative amount to the total bacteria load than intensive livestock and mixed agriculture for most flows (fig. 24D). Concentrations exceeding $200 \mathrm{cfu} / 100 \mathrm{~mL}$ are caused by residential runoff about 15 percent of the time, whereas concentrations exceeding $200 \mathrm{cfu} / 100 \mathrm{~mL}$ due to runoff from intensive livestock occur about 9 percent of the time. The bacteria concentration of runoff from intensive livestock is higher than runoff from residential areas for only about 1.5 percent of the time at Chino Creek outflow.
Simulation results for the CCM1 site indicated the lowest bacteria concentrations compared with results for all other sites (fig. 24E). Bacteria concentrations exceeded the $200 \mathrm{cfu} / 100 \mathrm{~mL}$ limit only 0.03 percent of the time. Runoff from the barren and vacant land use caused the maximum bacteria concentration. At CCM2, runoff from the residential and the commercial and services land uses was the primary source of bacteria concentration above 2,000 cfu/100 mL (fig. 24F). Runoff from mixed urban areas also provided substantial bacteria loading at this location. The relative contributions from the different land uses at Mill Creek outflow (fig. 24G) were 


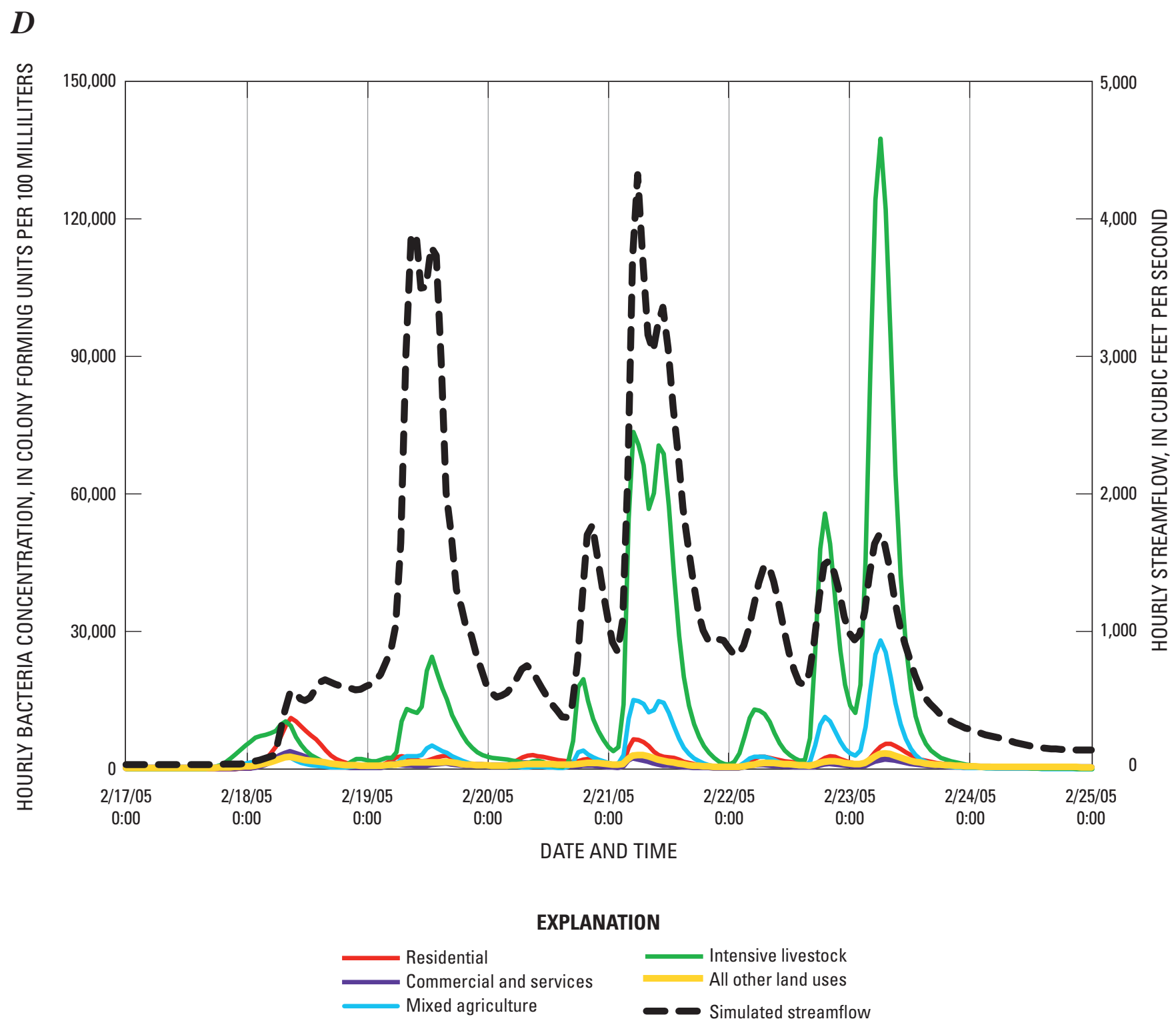

Figure 23. Continued.

similar to those at Chino Creek outflow (ig. 24D). Residential land use was the primary source of bacteria contamination exceeding $200 \mathrm{cfu} / 100 \mathrm{~mL}$ for most storm flows at both locations. However, runoff from intensive livestock had a greater average affect on Chino Creek outflow. At Mill Creek, runoff from intensive livestock exceeds $10,000 \mathrm{cfu} / 100 \mathrm{~mL}$ for only about 0.2 percent of the time, compared with about 1.2 percent of the time at Chino Creek.
The highest relative contribution to the average bacteria concentration was provided by runoff from residential areas at six of the twelve sites analyzed for land use contributions to bacteria contamination (table 13). Five of these sites were in the Mill Creek subbasin (Mill Creek outflow, sample site MC, stream gage 11073495, CCM2, and stream gage 1073493), 
$A$

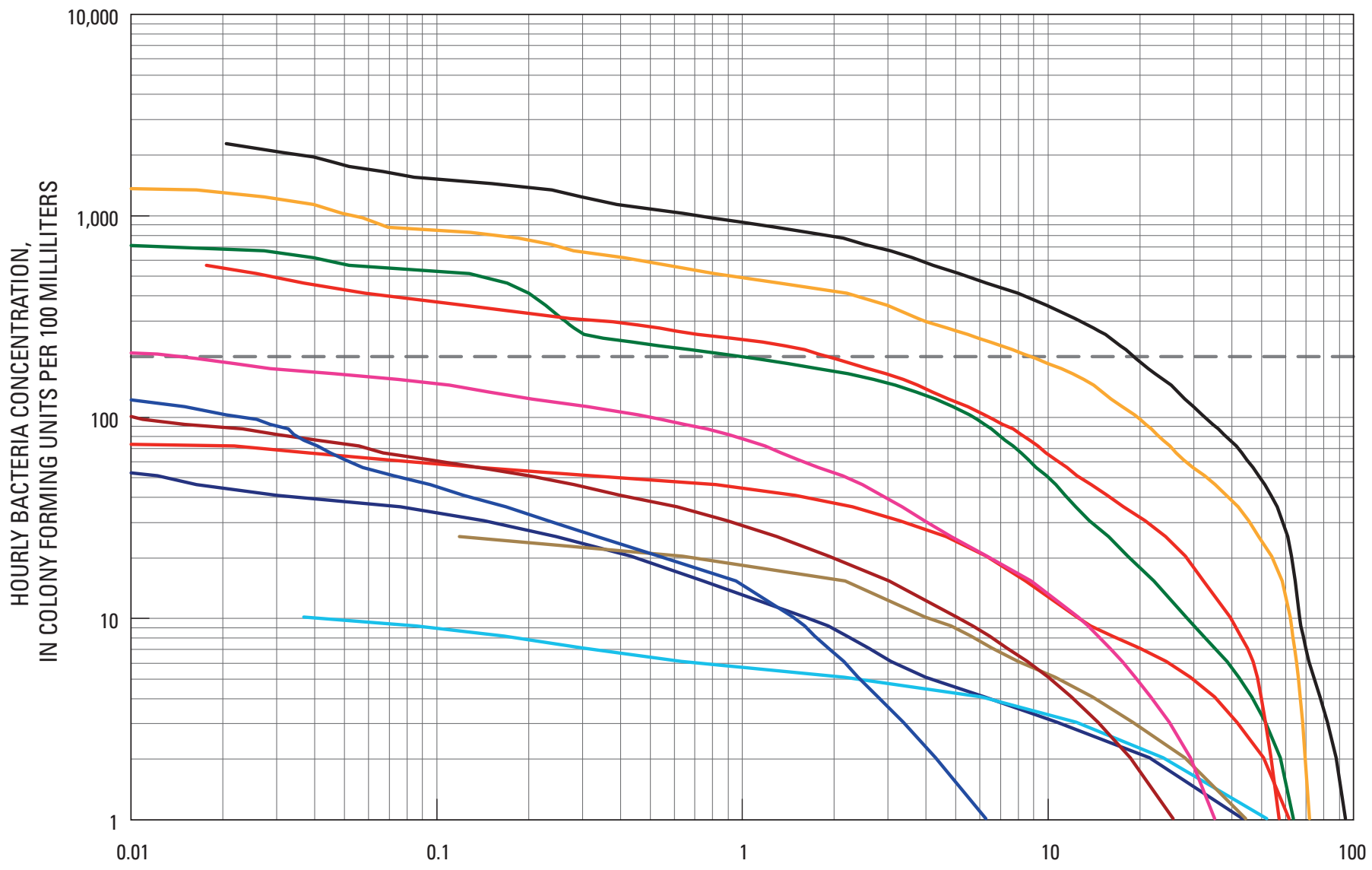

PERCENTAGE OF TIME BACTERIA CONCENTRATION EXCEEDED

EXPLANATION

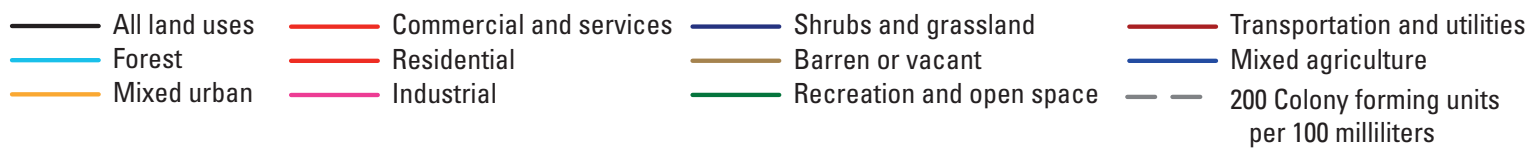

Figure 24. Concentration durations for simulated hourly bacteria concentrations affected by different land uses at $A$, San Antonio Dam outflow, $B$, sample site D, $C$, sample site PPOC, $D$, Chino Creek outflow, $E$, sample site CCM1, $F$, sample site CCM2, and $G$, Mill Creek outflow for water-years 1988-2005 in the Chino Basin, California.

whereas only one was in the Chino Creek subbasin. The maximum percentage of contributions to bacteria loading from residential areas ranged from 61 percent at the CCM2 and stream gage 11073493 sites to 40 percent at stream gage 11073360 (sample site CHIS). Runoff from intensive livestock was the dominant bacteria source for three of the twelve sites: Chino Creek outflow, sample site D, and sample site PPOC.
The highest percentage contribution to the average base-case bacteria concentration from a single land use in the central and southern parts of the Chino Basin was 78 percent for runoff from intensive livestock upstream of PPOC. The bacteria contribution from intensive livestock was also relatively high (66 percent) for sample site $\mathrm{D}$, which was also the location where the maximum bacteria concentrations were simulated 


\section{$\boldsymbol{B}$}

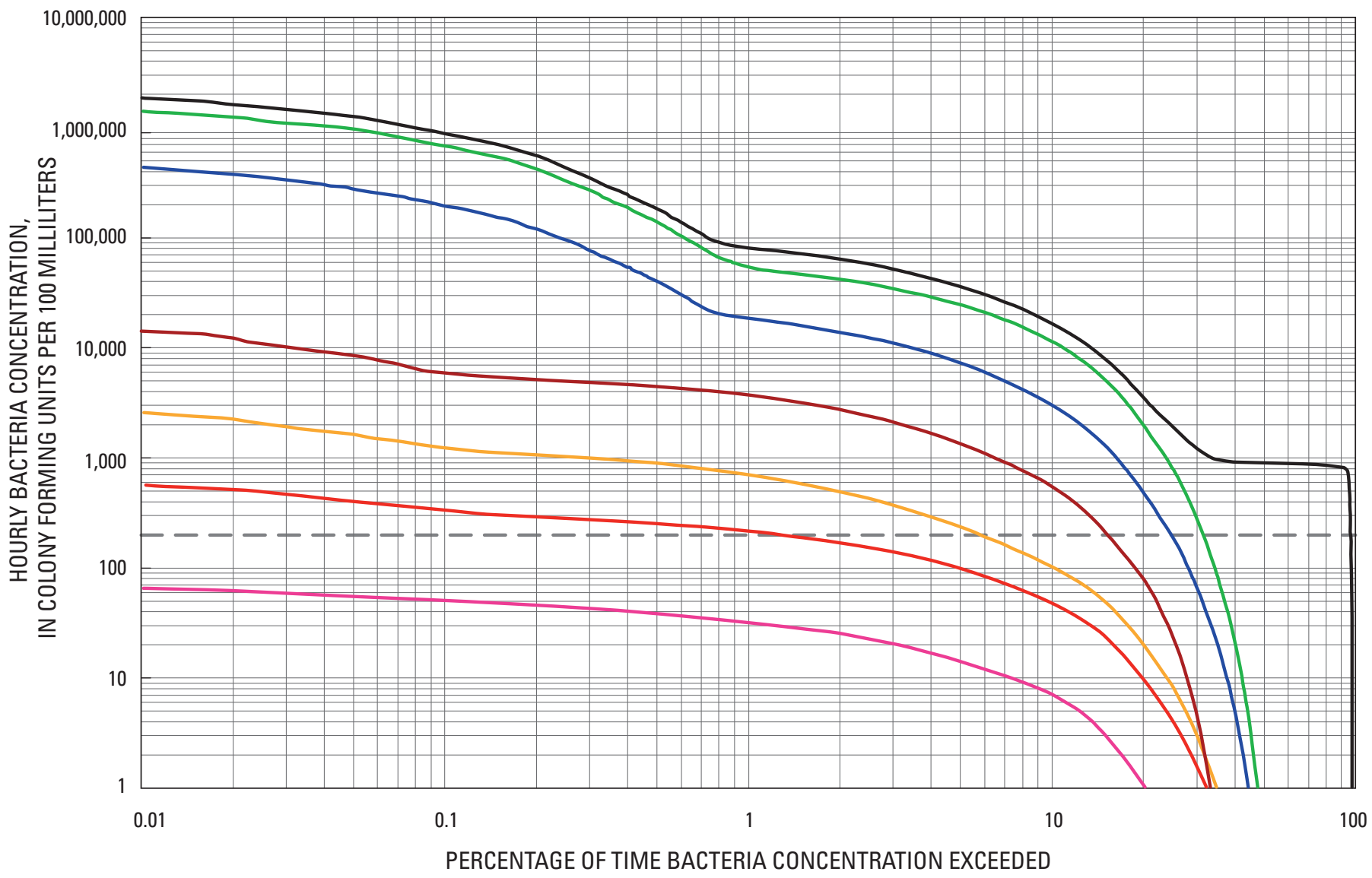

EXPLANATION
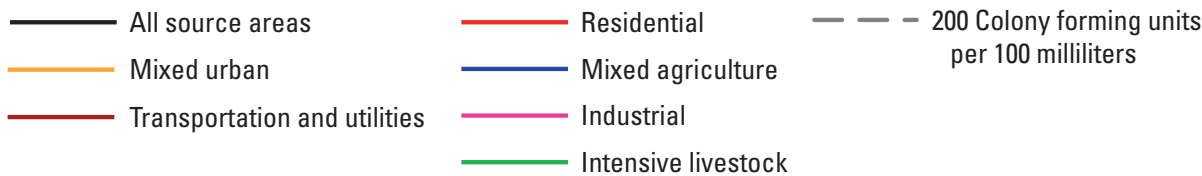

Figure 24. Continued.

(about 2.7 million cfu/100 mL). Commercial and services and mixed agriculture were also important bacteria sources for the central and southern parts of the Chino Basin. A maximum relative contribution to bacteria loading for commercial and services land use was 28 percent at stream gage 11073360 (sample site CHIS). A maximum contribution for the mixed agricultural land use was 21 percent at the PPOC site. The highest contribution from a single land-use area within the Chino Basin was for the mixed urban land use at sample site IHC. Model results indicated that industrial, utilities and transportation and recreation and open space land uses were not important sources of bacteria contamination, in terms of average concentration, for the Chino Basin. 


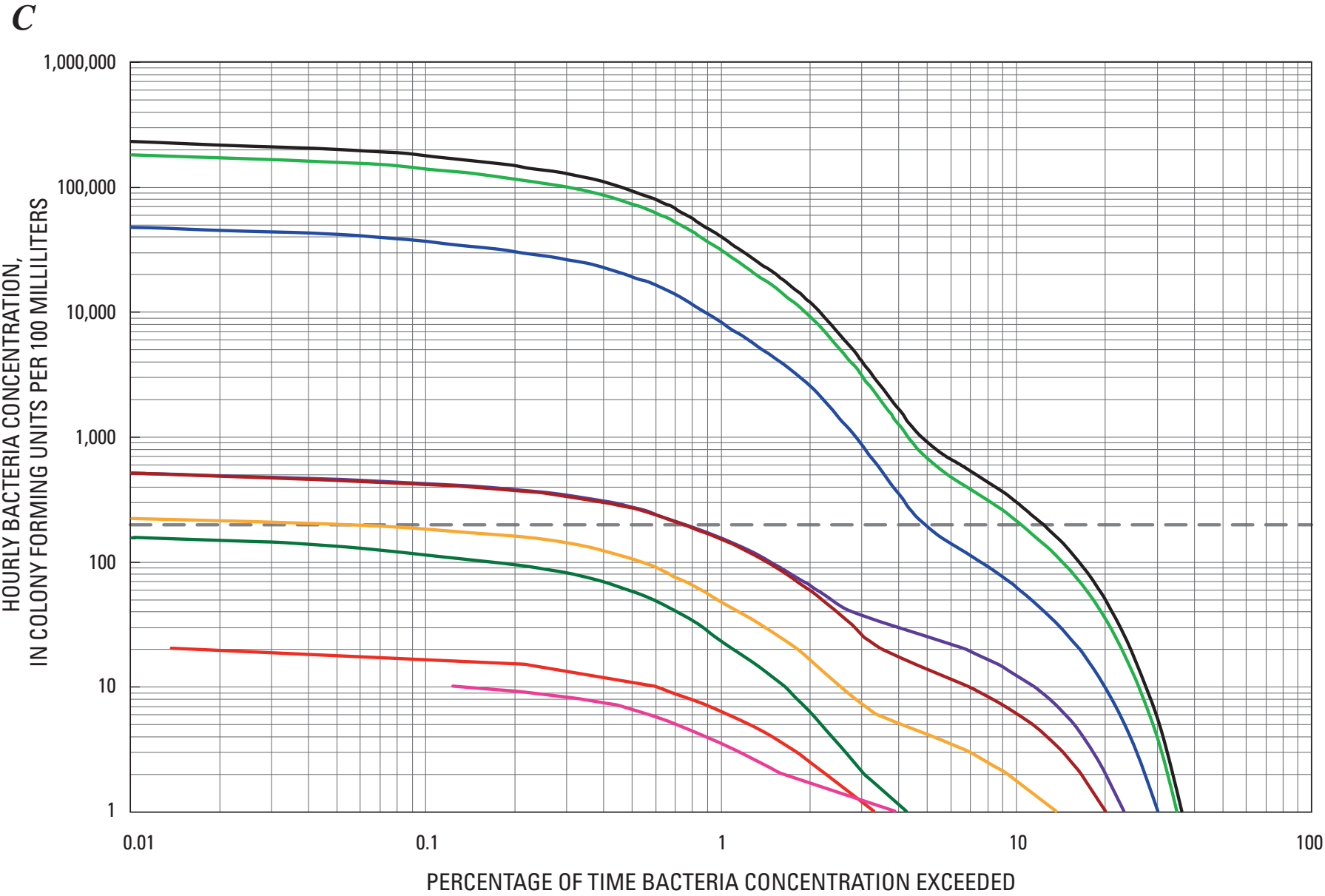

PERCENTAGE OF TIME BACTERIA CONCENTRATION EXCEEDED

\section{EXPLANATION}
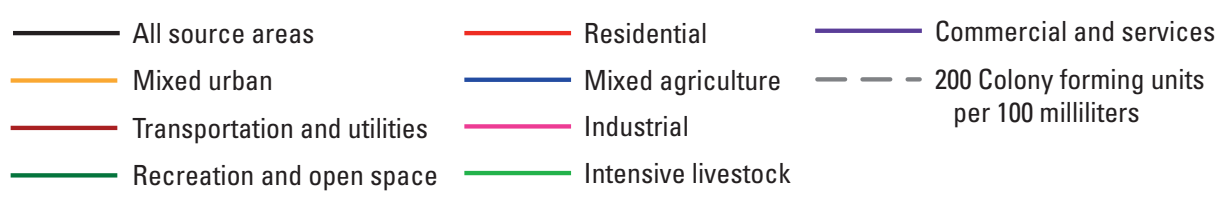

Figure 24. Continued. 
D
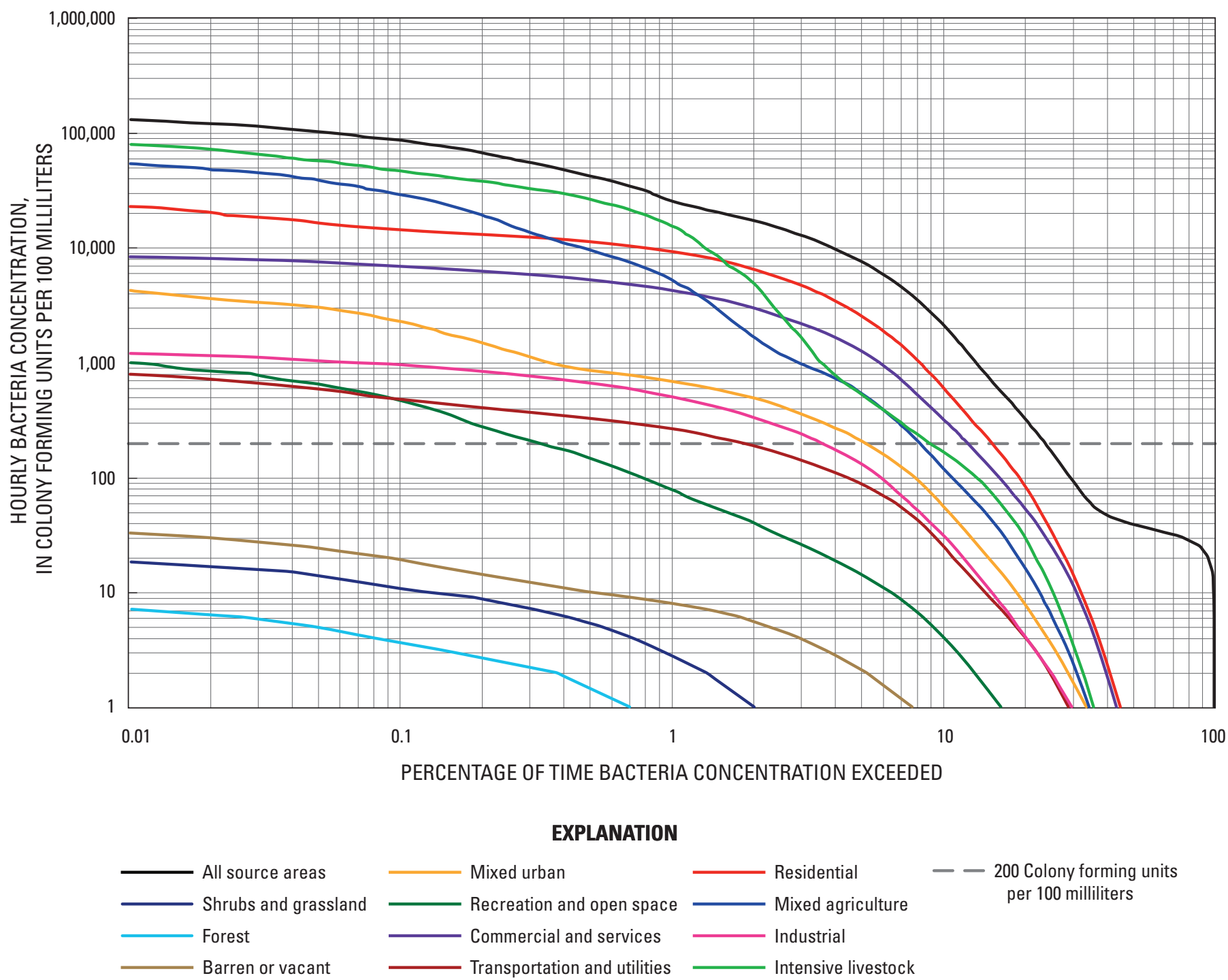

Figure 24. Continued. 
$\boldsymbol{E}$
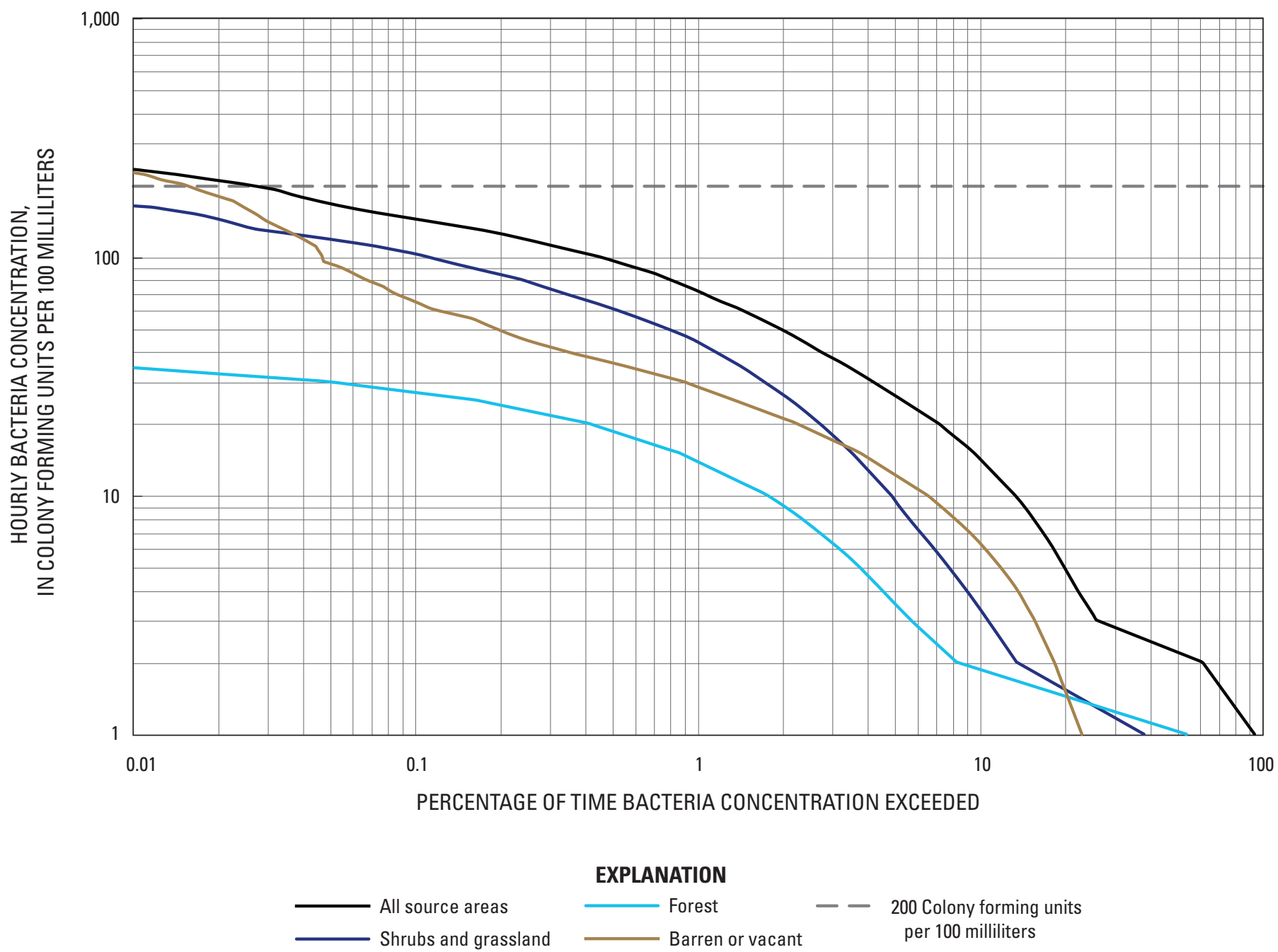

Figure 24. Continued. 


\section{$\boldsymbol{F}$}

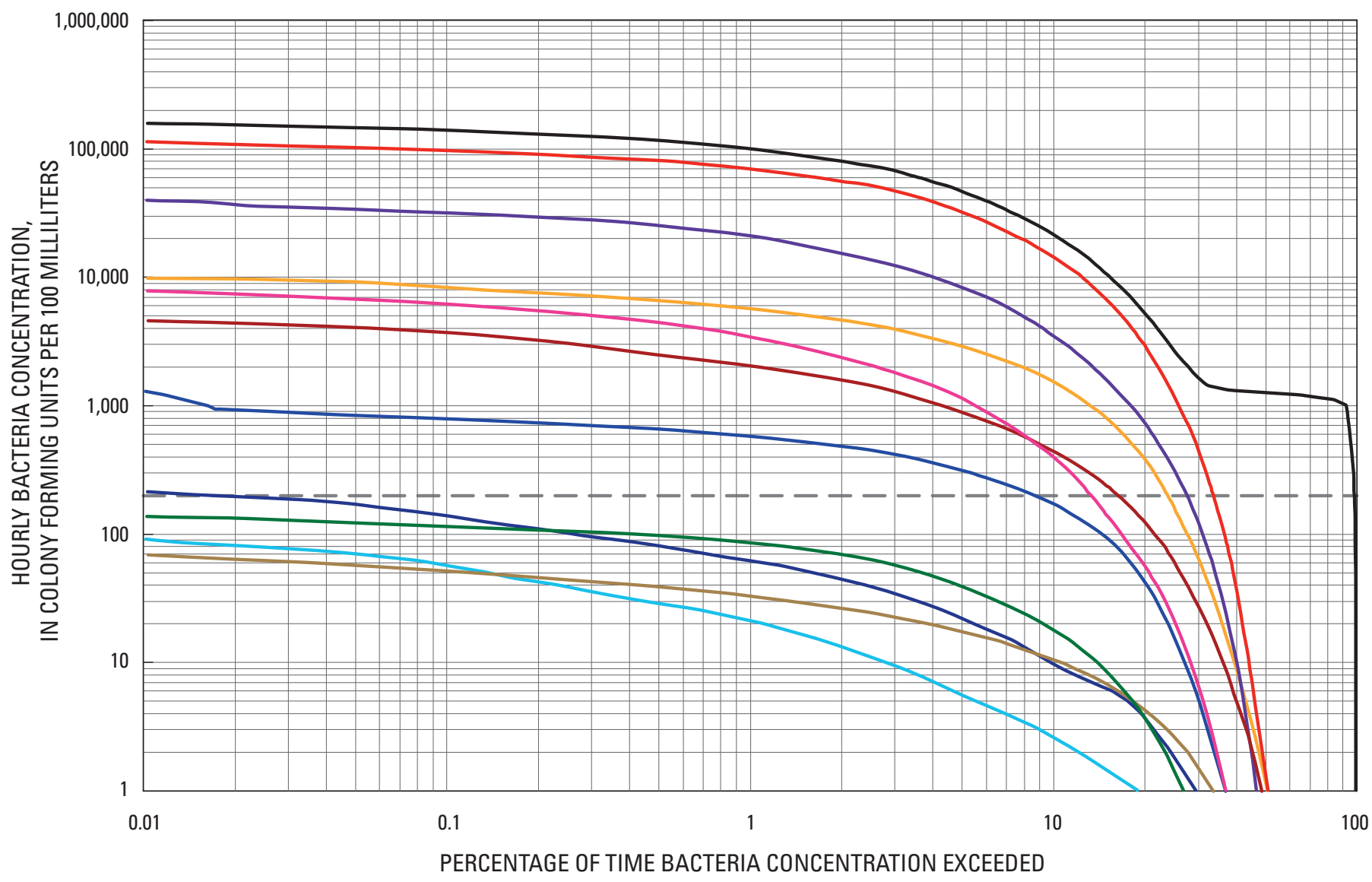

EXPLANATION

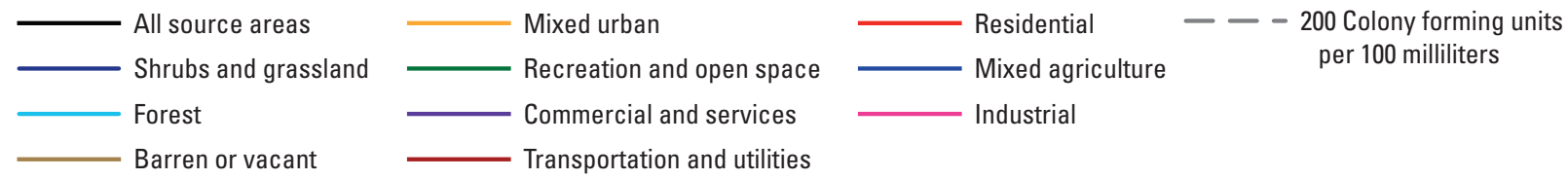

Figure 24. Continued. 
$G$

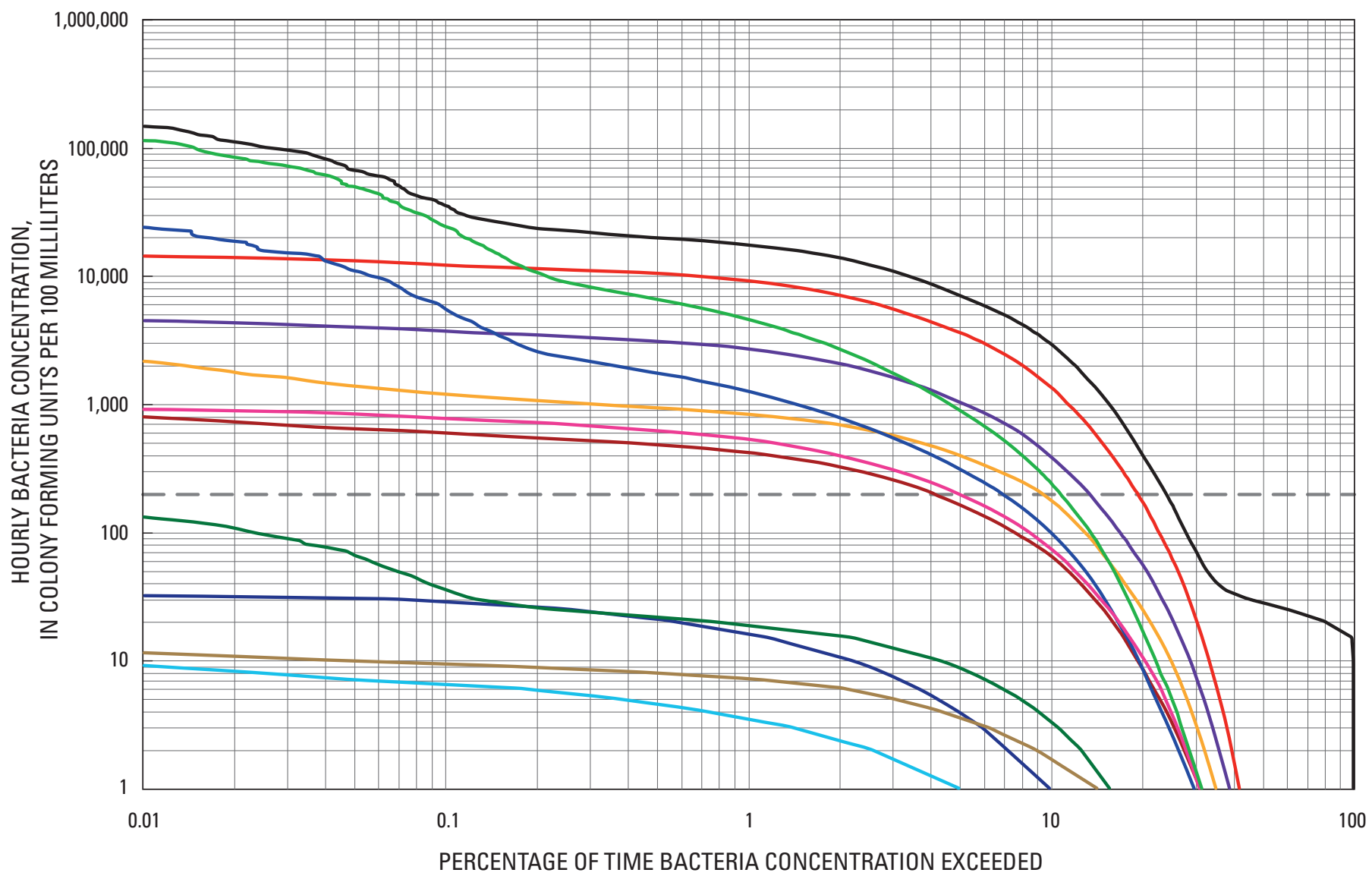

PERCENTAGE OF TIME BACTERIA CONCENTRATION EXCEEDED

EXPLANATION

\begin{tabular}{lll}
\hline All source areas & Mixed urban & Residential \\
Shrubs and grassland & Recreation and open space & Mixed agriculture \\
\cline { 3 - 3 } Forest & Commercial and services & Industrial \\
Barren or vacant & Transportation and utilities & Intensive livestock
\end{tabular}

Figure 24. Continued. 


\section{Model Application: Analysis of Basin Response to Possible Climate and Land-Use Changes}

\section{Climate Scenarios}

Model simulations were made of various climate scenarios to test the hydrologic and transport sensitivity of the Chino Basin model simulations to possible changes in precipitation and air temperature.

\section{Development}

Climate scenarios were developed to represent possible conditions and do not represent predictions or indications of potential future conditions. The scenarios were used to indicate watershed responses to changes in climate. The results provide an indication of the sensitivity of simulated flow and bacteria concentrations to changes in precipitation and air temperature while model parameters remained the same. The model results were evaluated for the 1988-2005 simulation period. Simulations were started on 1/1/1985 to allow for a 3-year model ramp up to 1988 and ran continuously through 12/31/2005.

Two different air temperature scenarios were defined as (1) a constant $5^{\circ} \mathrm{F}$ increase in hourly air temperature and (2) a $5^{\circ} \mathrm{F}$ decrease in hourly air temperature. The air temperature scenarios were used primarily to evaluate watershed responses and model sensitivity to changes in snow fall, snowpack storage, and snowmelt in the higher altitude subwatersheds. In general, the development and persistence of a snow pack and the timing of snow melt can be sensitive to small changes in air temperature. Although changes in air temperature can change the estimates of hourly PET (a decrease in air temperature decreases PET and an increase in air temperature increases PET), these changes were not applied to the PET estimates because this effect was assumed to be small relative to the effect of air temperature on snowmelt.

Eight different precipitation scenarios were developed. Seven scenarios were developed using a simple scaling of the hourly precipitation inputs, with scaling factors of $0,0.1,0.5$, $0.8,1.2,1.5$, and 2.0. The scaling factor 0 was used to evaluate results based only on the inflows from wastewater effluent, water deliveries, and nuisance flow. The eighth precipitation scenario was developed using a scaling factor of 0.2 for calendar years 1988-1996 and a scaling factor of 1.8 for calendar years 1997-2005. The eighth scenario was used to evaluate the effect of increased precipitation variability on simulated flow and bacteria transport (a dry period followed by a wet period).

\section{Results of Air Temperature Scenarios}

Simulated 1988-2005 streamflow and bacteria concentration for the two air temperature scenarios were compared with the results obtained for the base case (current climate) simulation. Two air temperature scenarios—one assuming a $5^{\circ} \mathrm{F}$ decrease in air temperature and one assuming a $5^{\circ} \mathrm{F}$ increase - were simulated for five locations (tables 14 and $\underline{15}$ ). The results for the San Antonio Canyon submodel using the $5^{\circ} \mathrm{F}$ decrease indicated a significant increase in the simulated monthly snow pack for upper San Antonio Canyon (fig. 25A), upstream of sample site IHC. Simulations of water years having the greatest snow accumulations (1993, 1995, 1998, and 2005) showed a maximum monthly snow pack depth approximately 30 percent greater than that for the base case simulation. Results for upper San Antonio Canyon using the $5^{\circ} \mathrm{F}$ increase indicated an even greater relative change in monthly snow pack depth; for most years, the snow pack depth was approximately 70 to 80 percent less than that for the base-case simulation.

Simulation results for monthly streamflow indicate changes in the magnitude and the timing of streamflow for upper San Antonio Canyon in response to the changes in air temperature. The $5^{\circ} \mathrm{F}$ decrease in air temperature caused maximum monthly streamflow to shift into later spring (fig. 25B). The $5^{\circ} \mathrm{F}$ increase in air temperature caused a significant (about 30 to 50 percent) increase in maximum monthly streamflow during some winters, especially for the wetter than average years, and minimal to zero flows during summer.

Simulated monthly bacteria concentrations indicated a complex response to the changes in streamflow caused by the differences in snow accumulation and melt as a result of the decrease and increase in air temperature in upper San Antonio Canyon (fig. 25C). During most months and water years, the decrease in air temperature caused an increase in bacteria concentrations, whereas the increase in air temperature usually caused a decrease in monthly bacteria concentrations. Two exceptions to this pattern were the dry water-years 1994 and 1999, when the increased air temperature scenario caused the maximum monthly bacteria concentration to be about 30 percent higher than that for the base case and the decreased air temperature scenario caused the maximum monthly concentrations to be slightly less than that for the base case. The complex response is due to the interplay between (1) bacteria washoff during overland flow, which tends to increase as temperature increases because less precipitation occurs as snow, and (2) baseflow concentrations, which for this study were represented as including point sources along stream channels. Baseflow concentrations tend to increase as flows decrease, and flows decrease as temperature decreases. 
Table 14A. Summary of 1988-2005 simulation results for air temperature scenarios at sample site IHC and San Antonio Dam outflow in the Chino Creek subbasin, California.

[Temperature in degrees Fahrenheit. ft $3 / \mathrm{s}$, cubic feet per second; cfu/100 mL, colony forming units per 100 milliliters; \%, percent; bacteria refers to fecal bacteria. The reported significant figures do not imply a level of accuracy attributed to the simulation results]

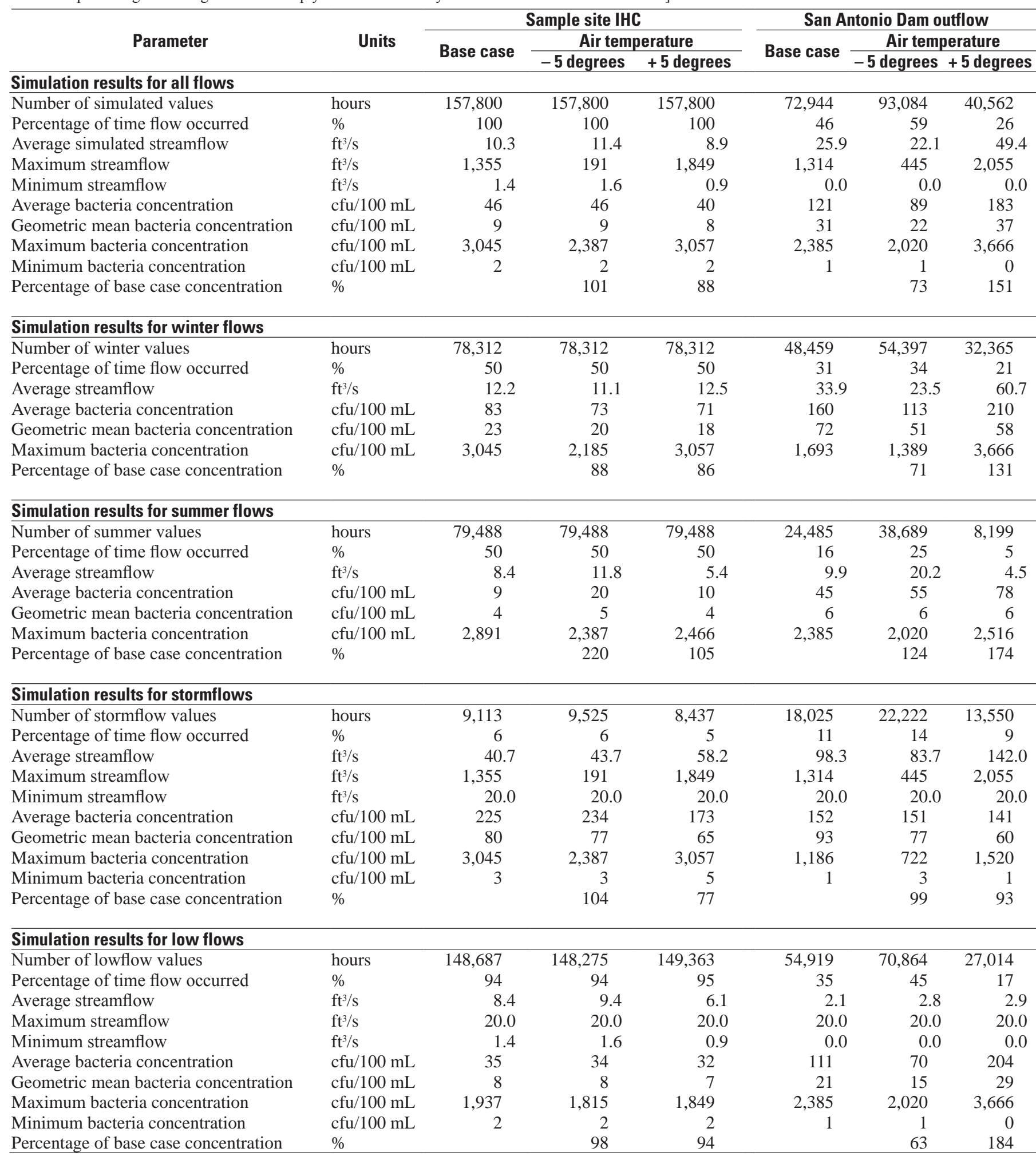


Table 14B. Summary of 1988-2005 simulation results for air temperature scenarios at sample site CCM1 and Mill Creek outflow in the Mill Creek subbasin, California.

[Temperature in degrees Fahrenheit. $\mathrm{ft} 3 / \mathrm{s}$, cubic feet per second; cfu/100 mL, colony forming units per 100 milliliters; \%, percent; bacteria refers to fecal bacteria. The reported significant figures do not imply a level of accuracy attributed to the simulation results.]

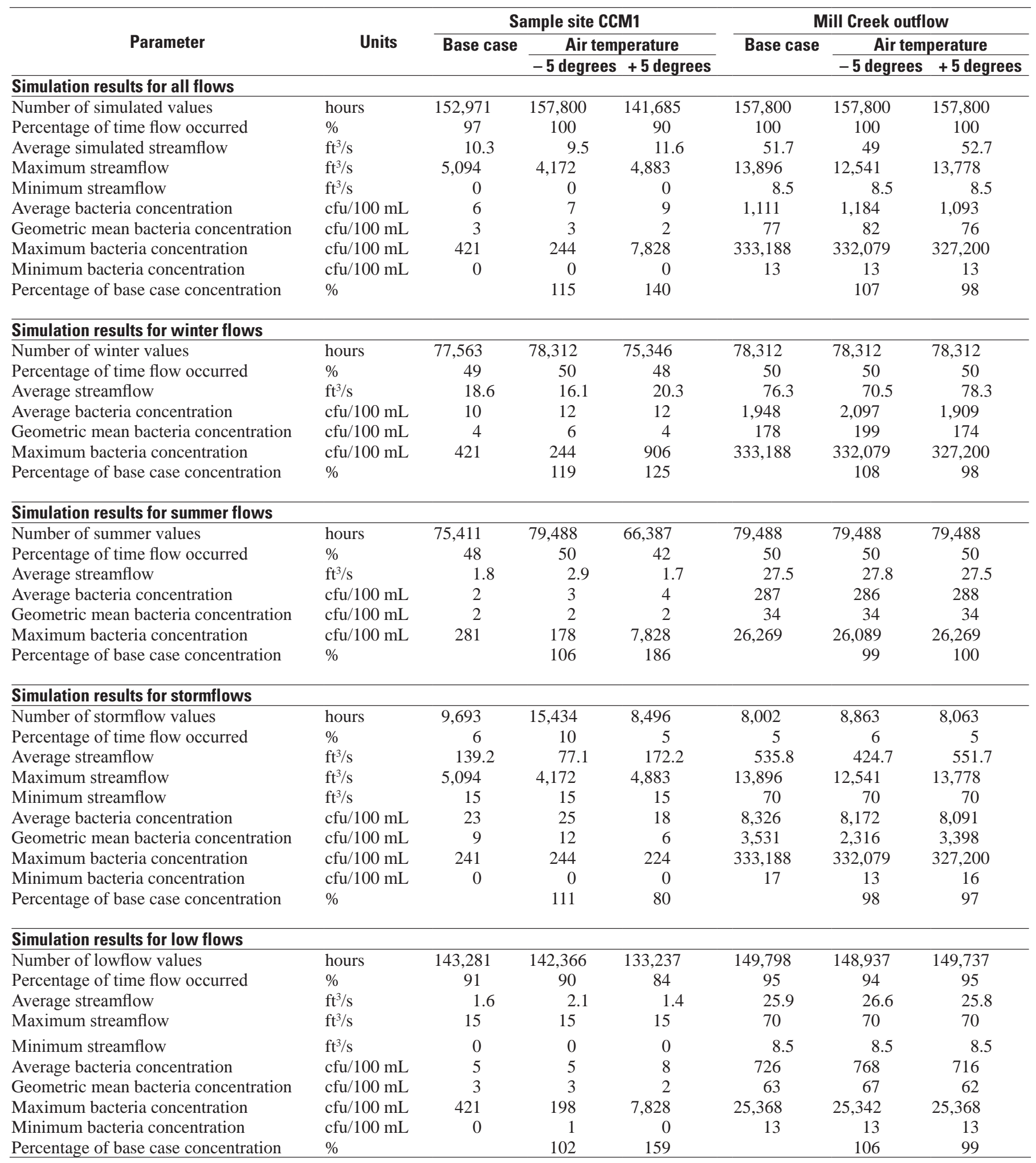




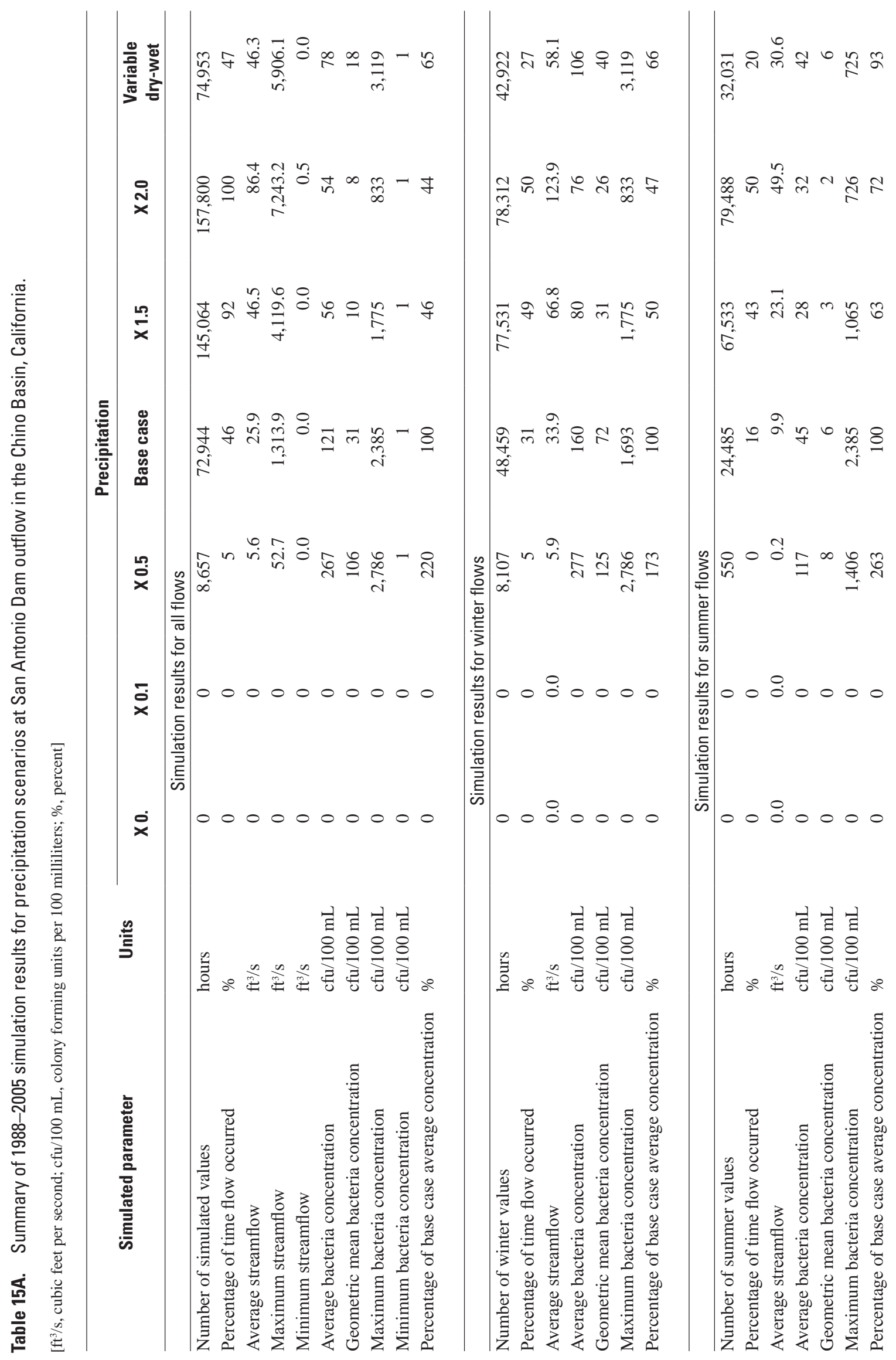




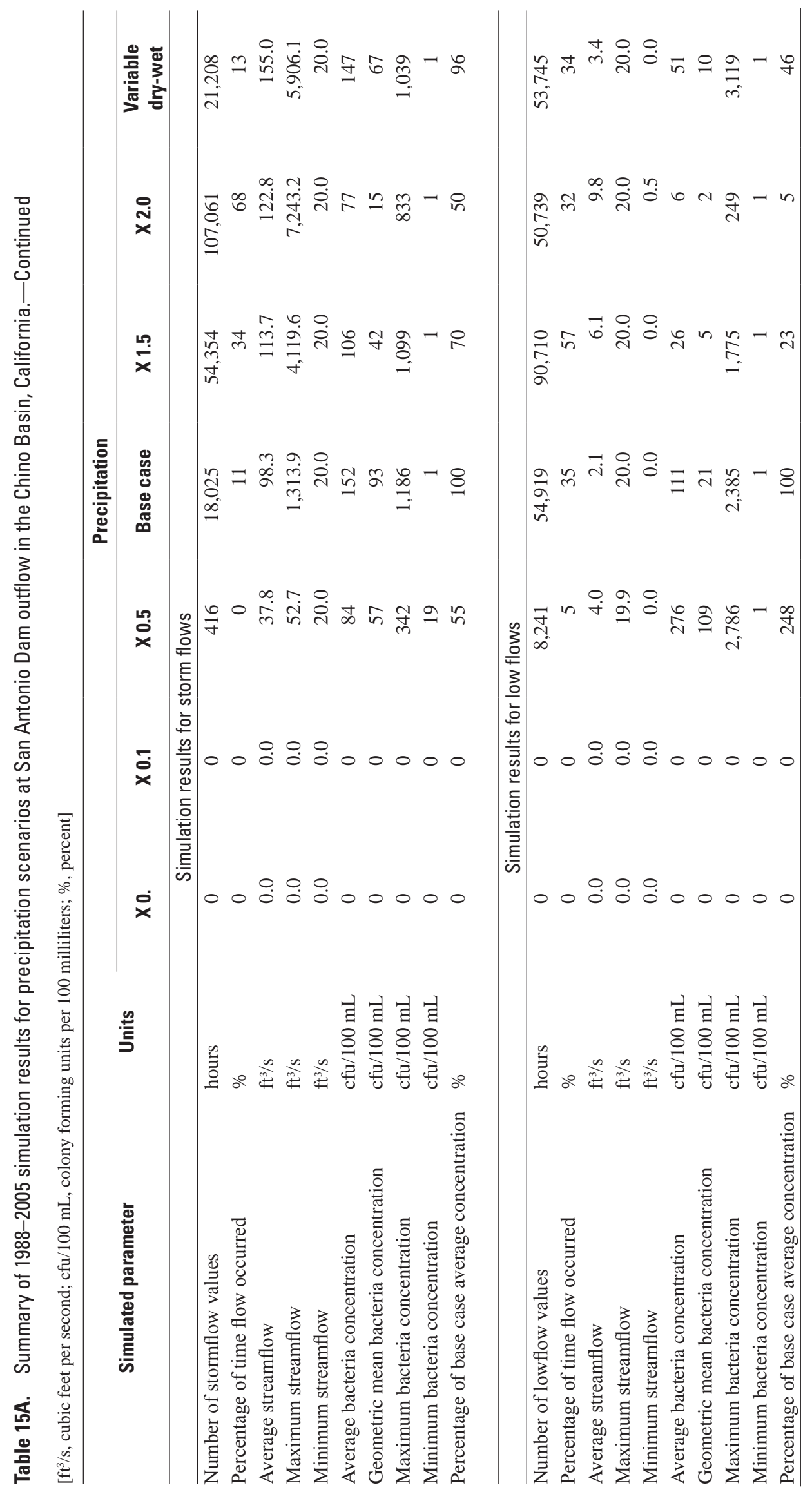




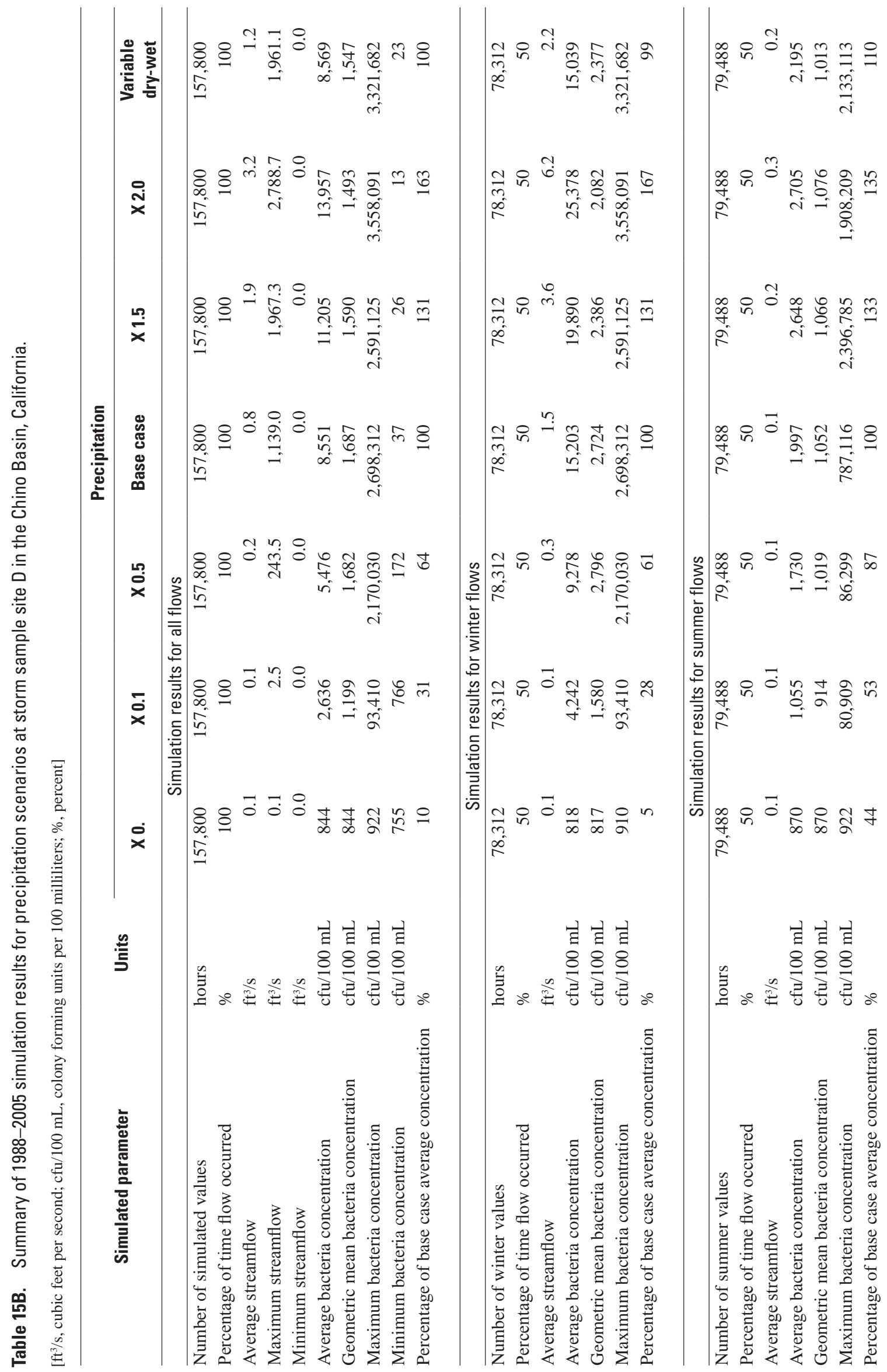




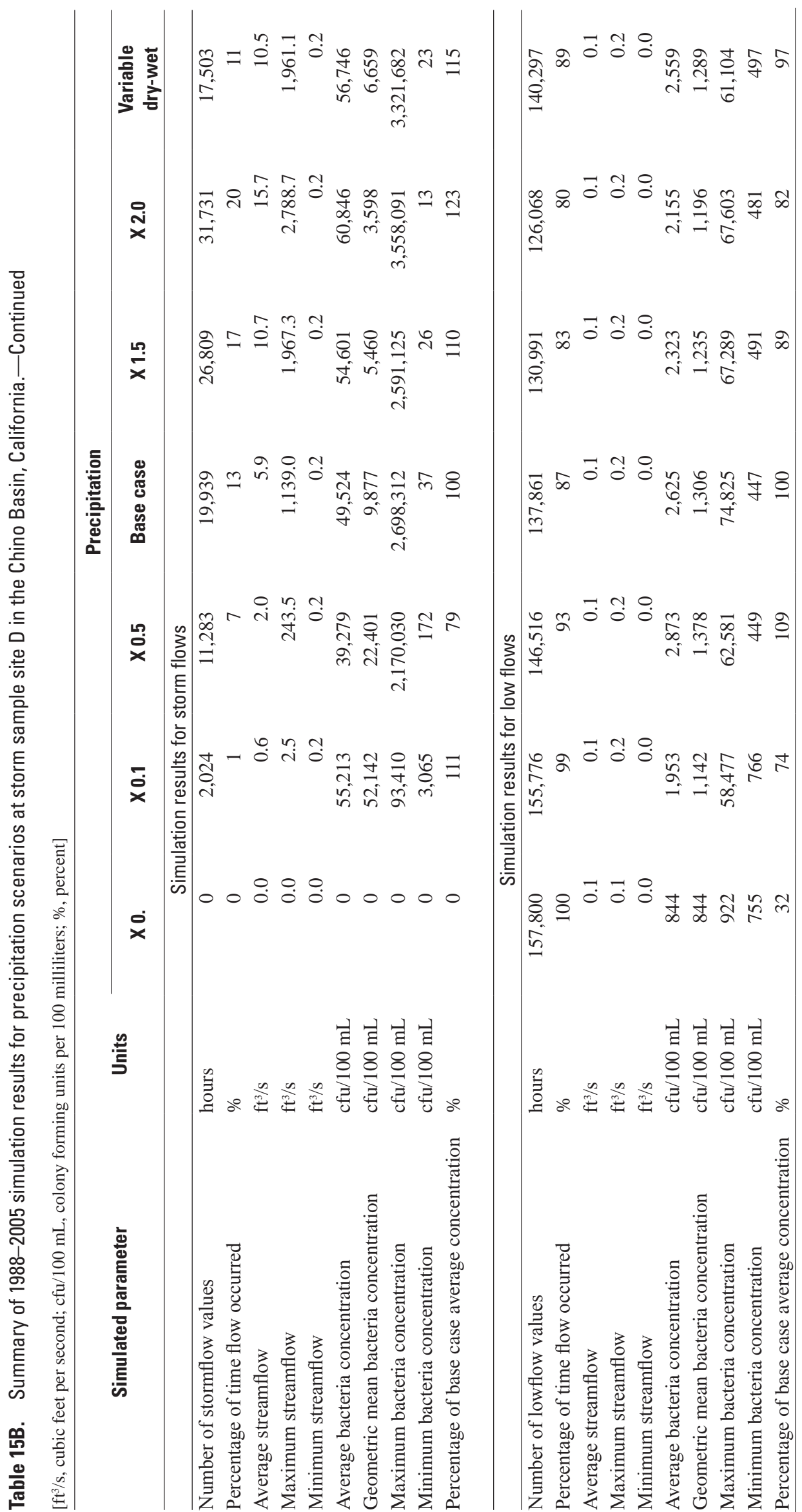




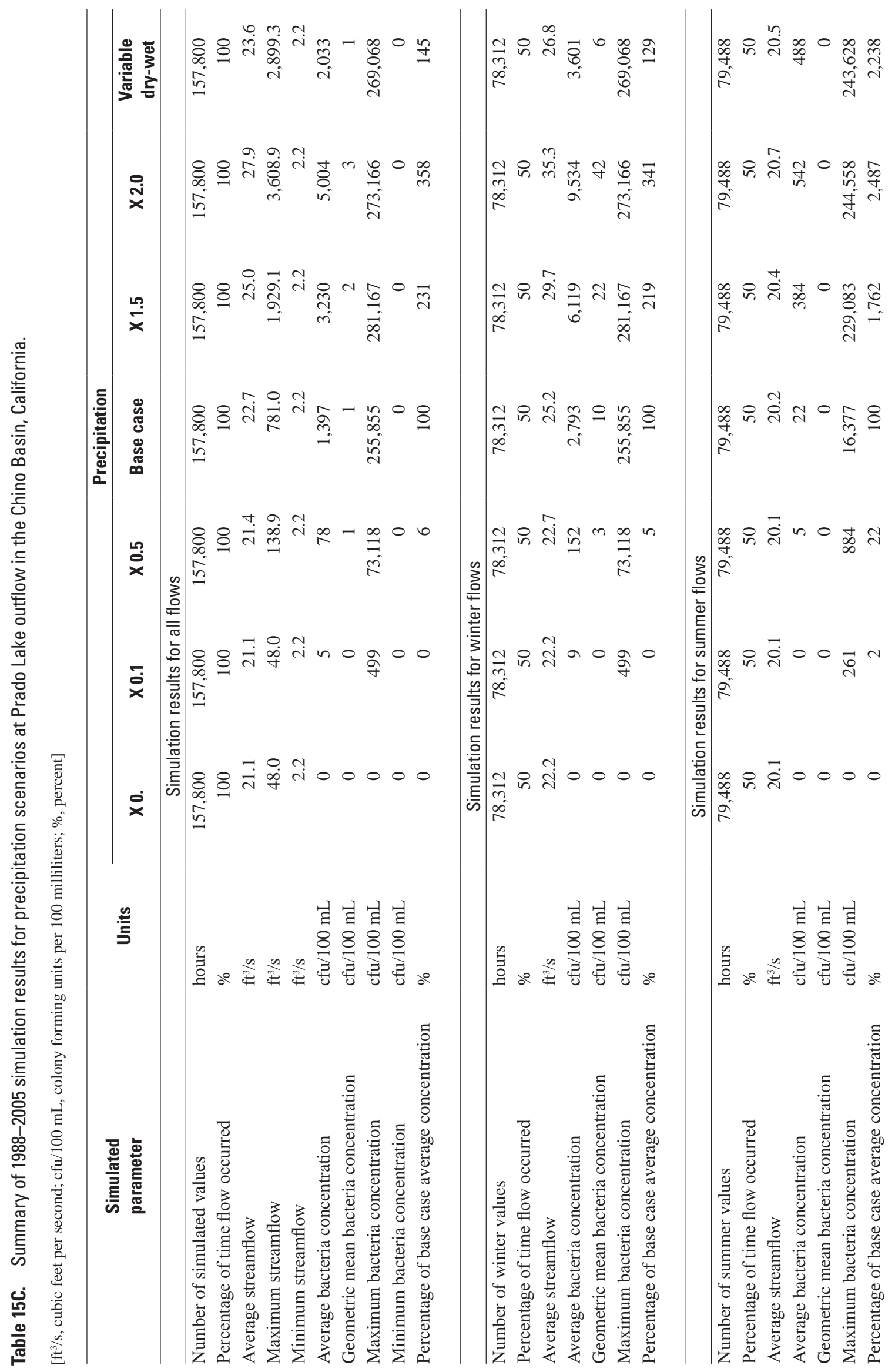




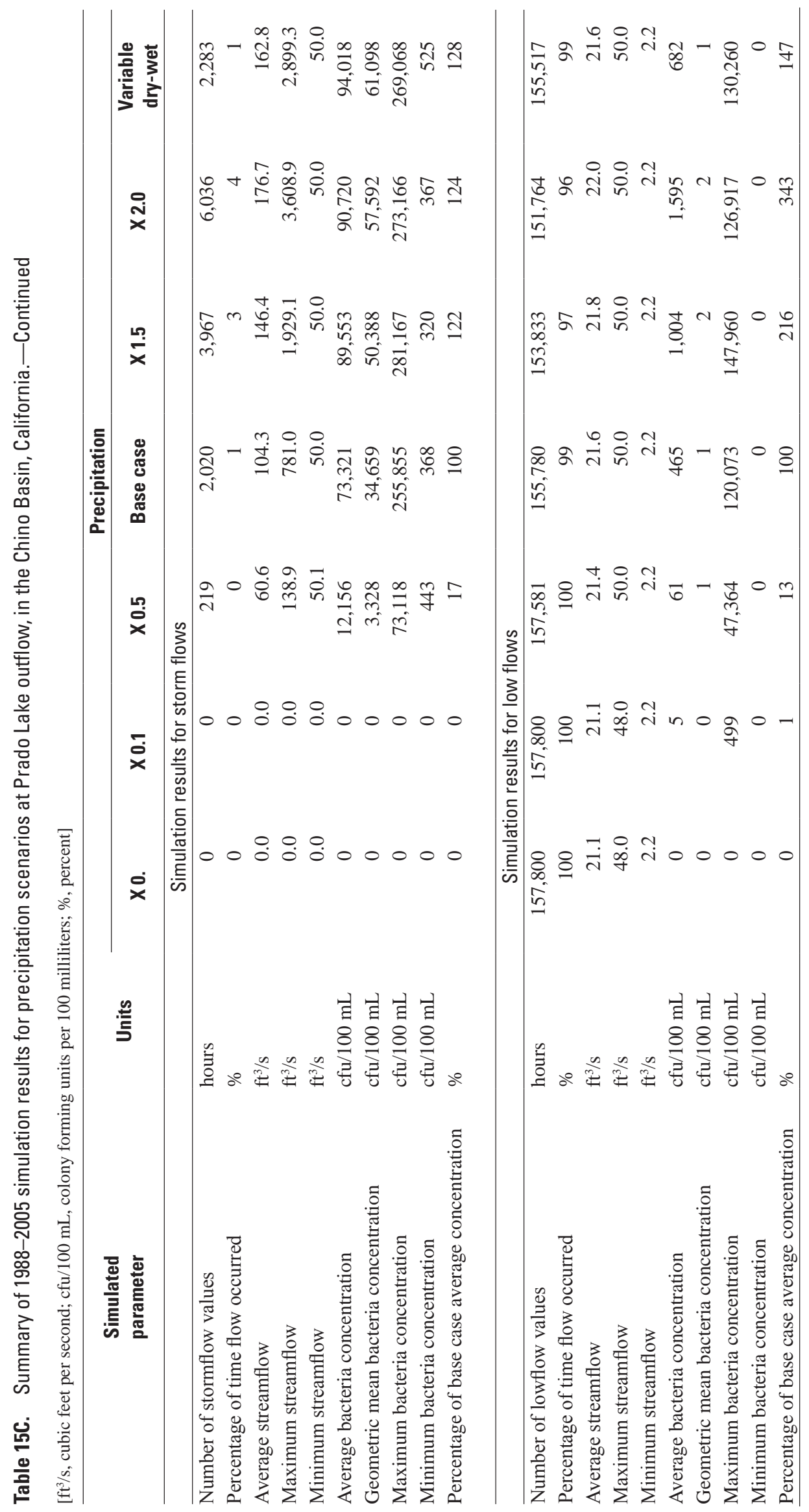




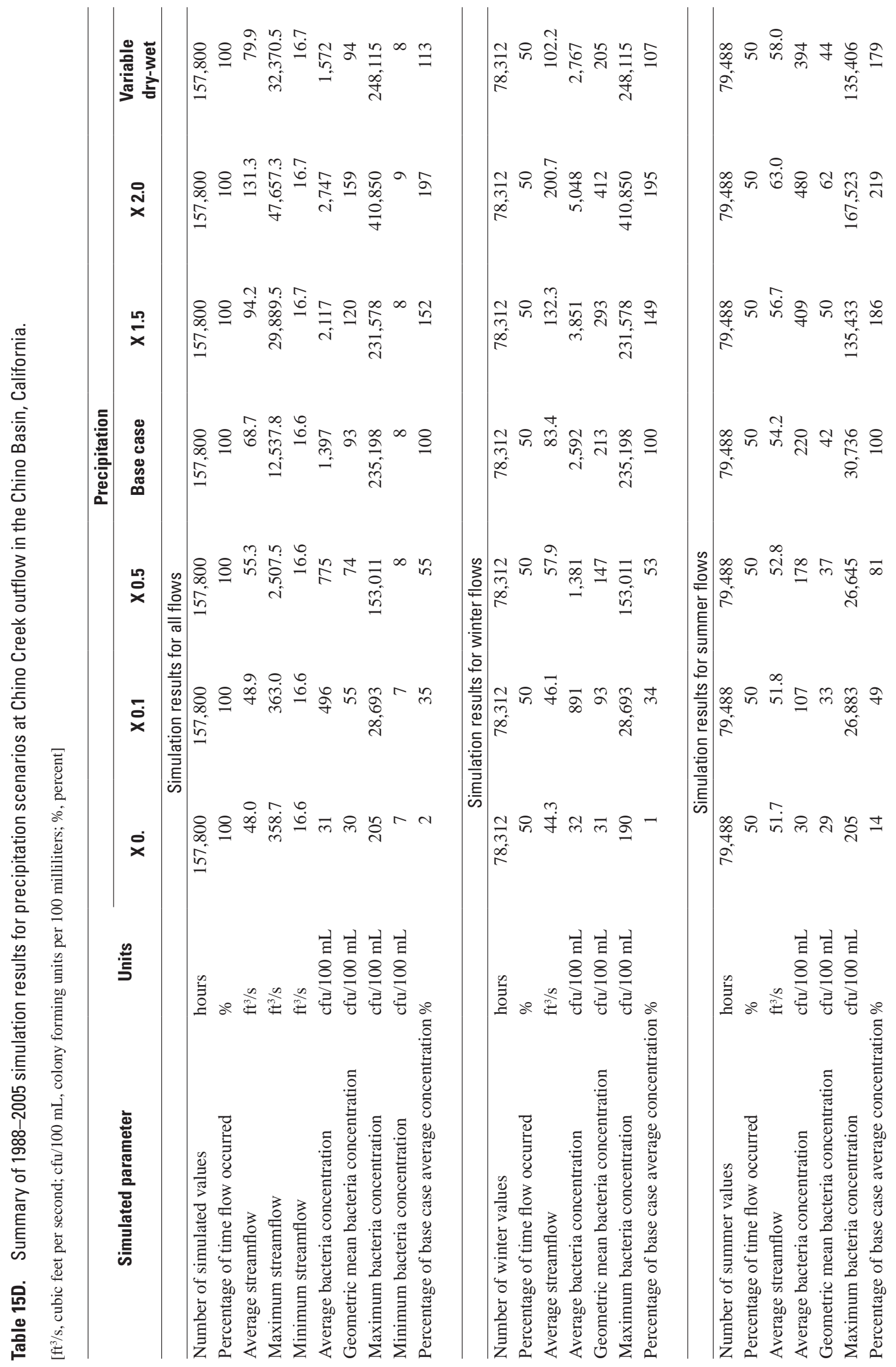




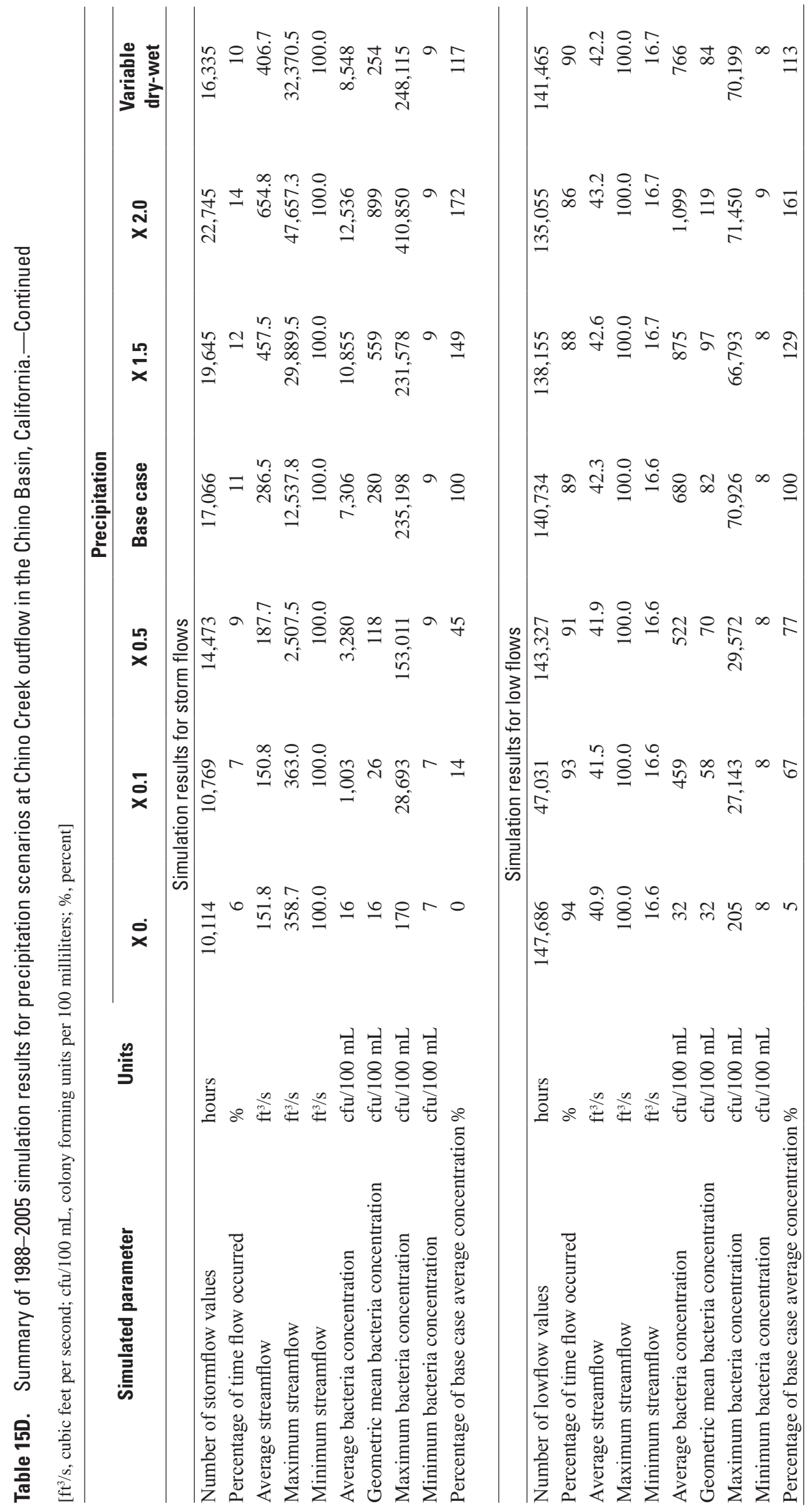




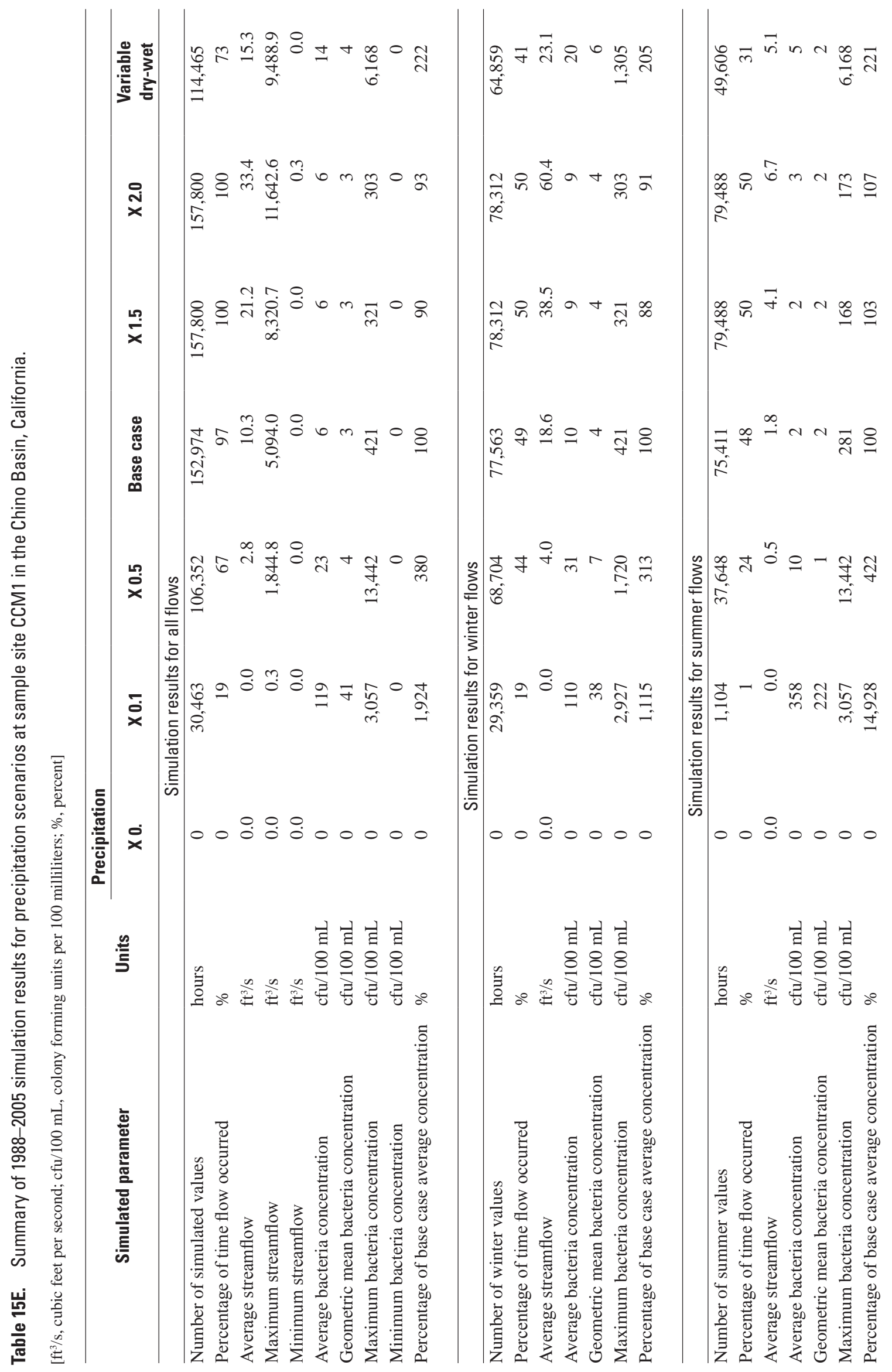




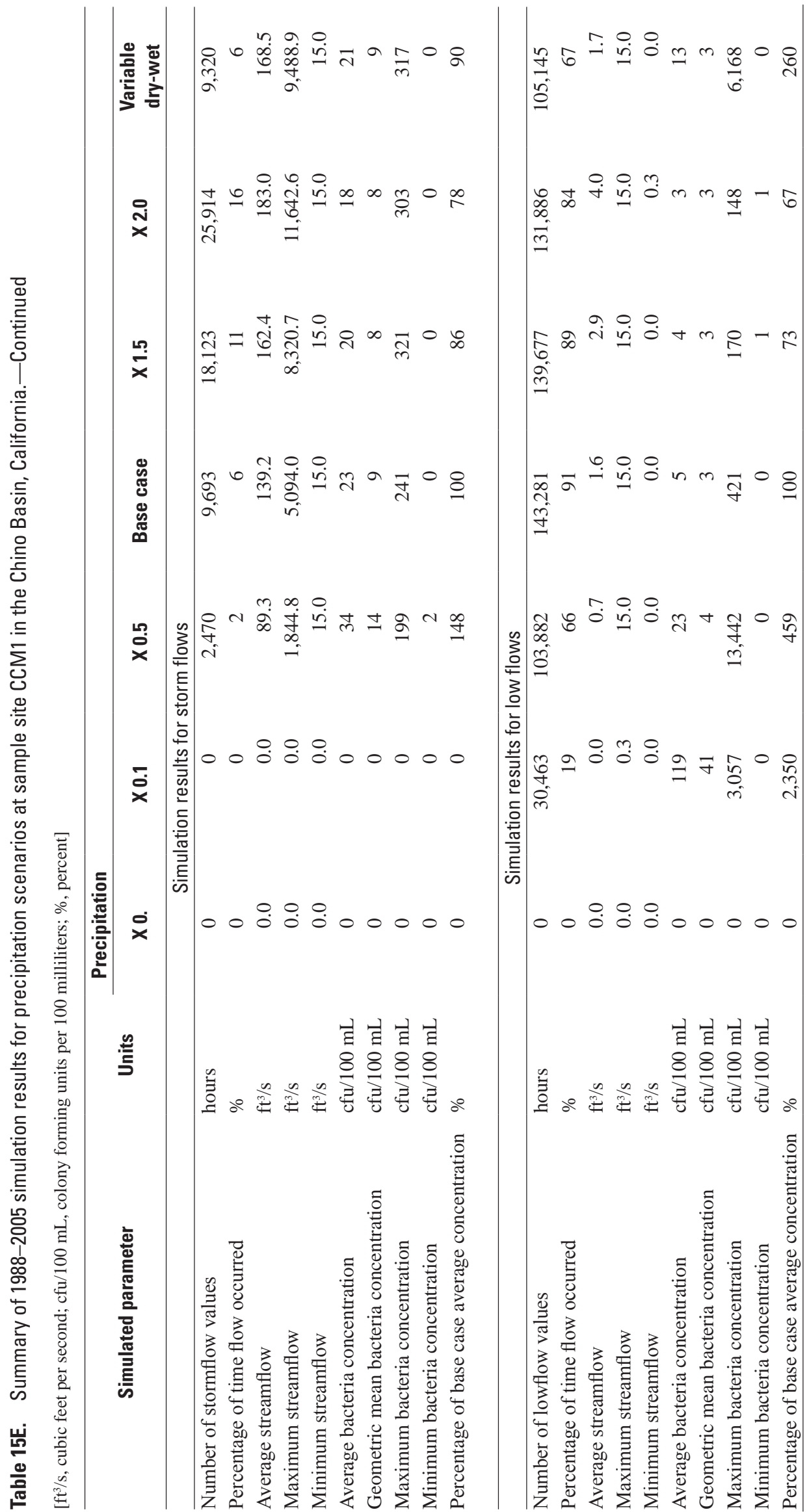




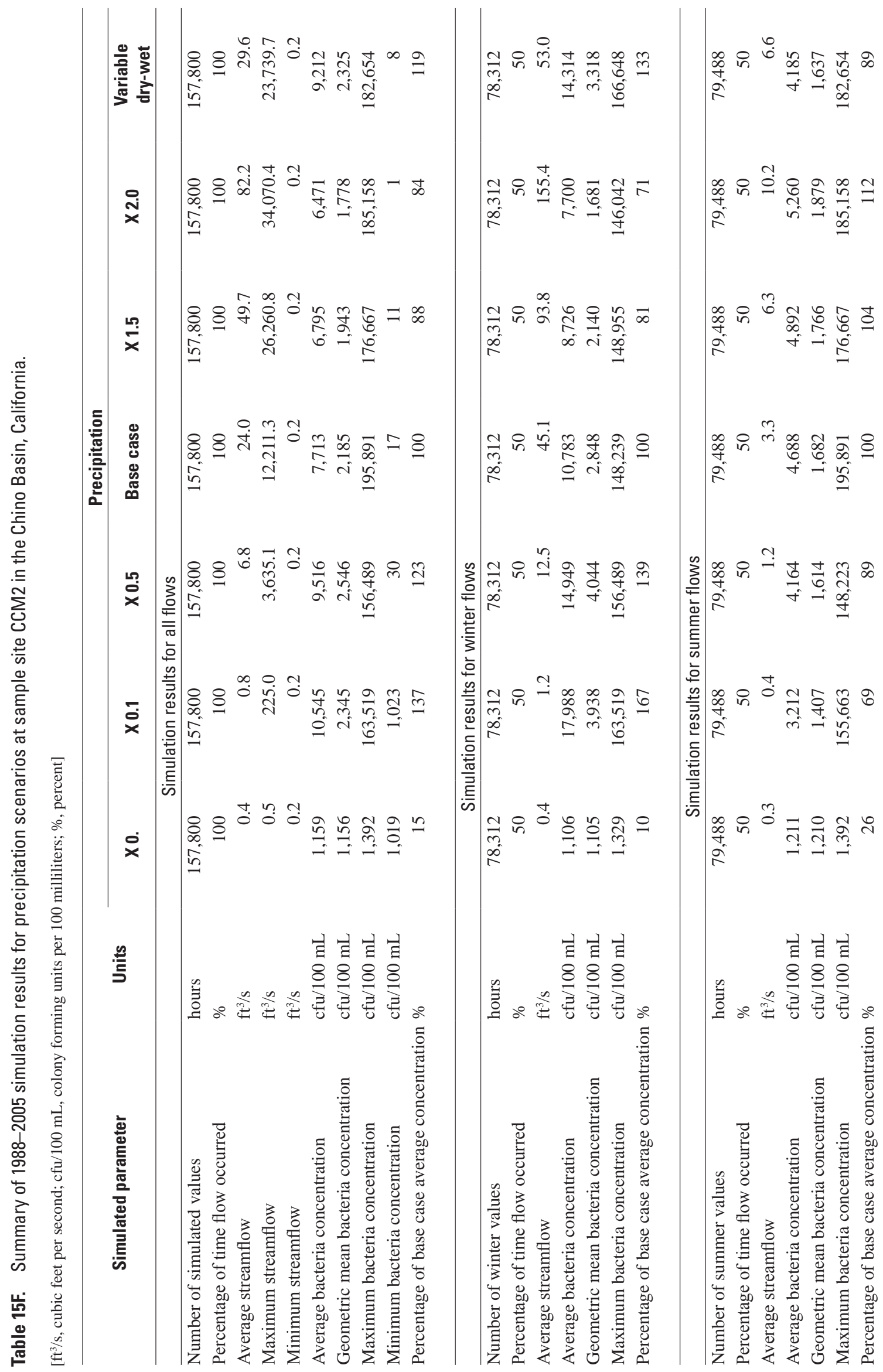




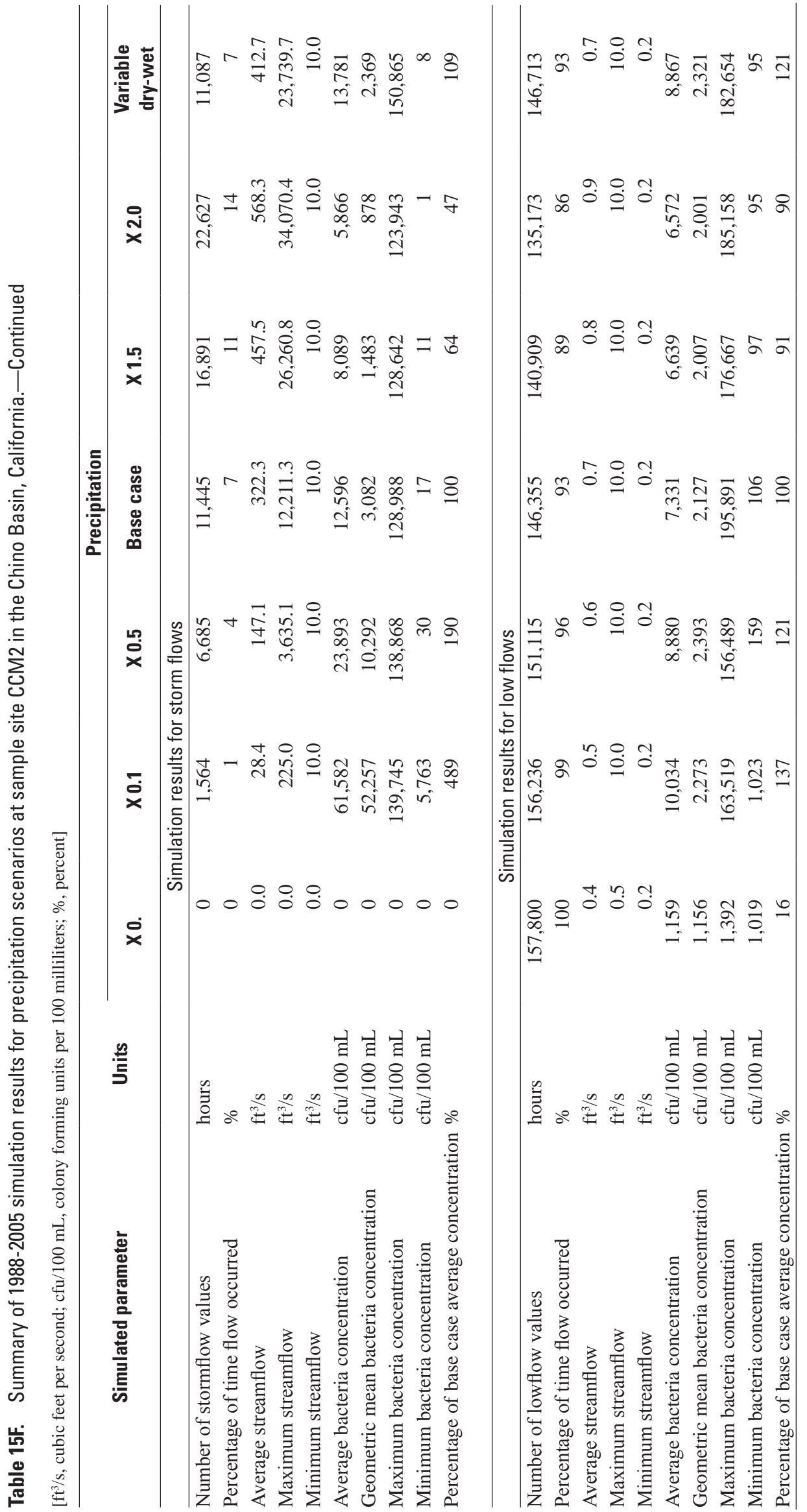




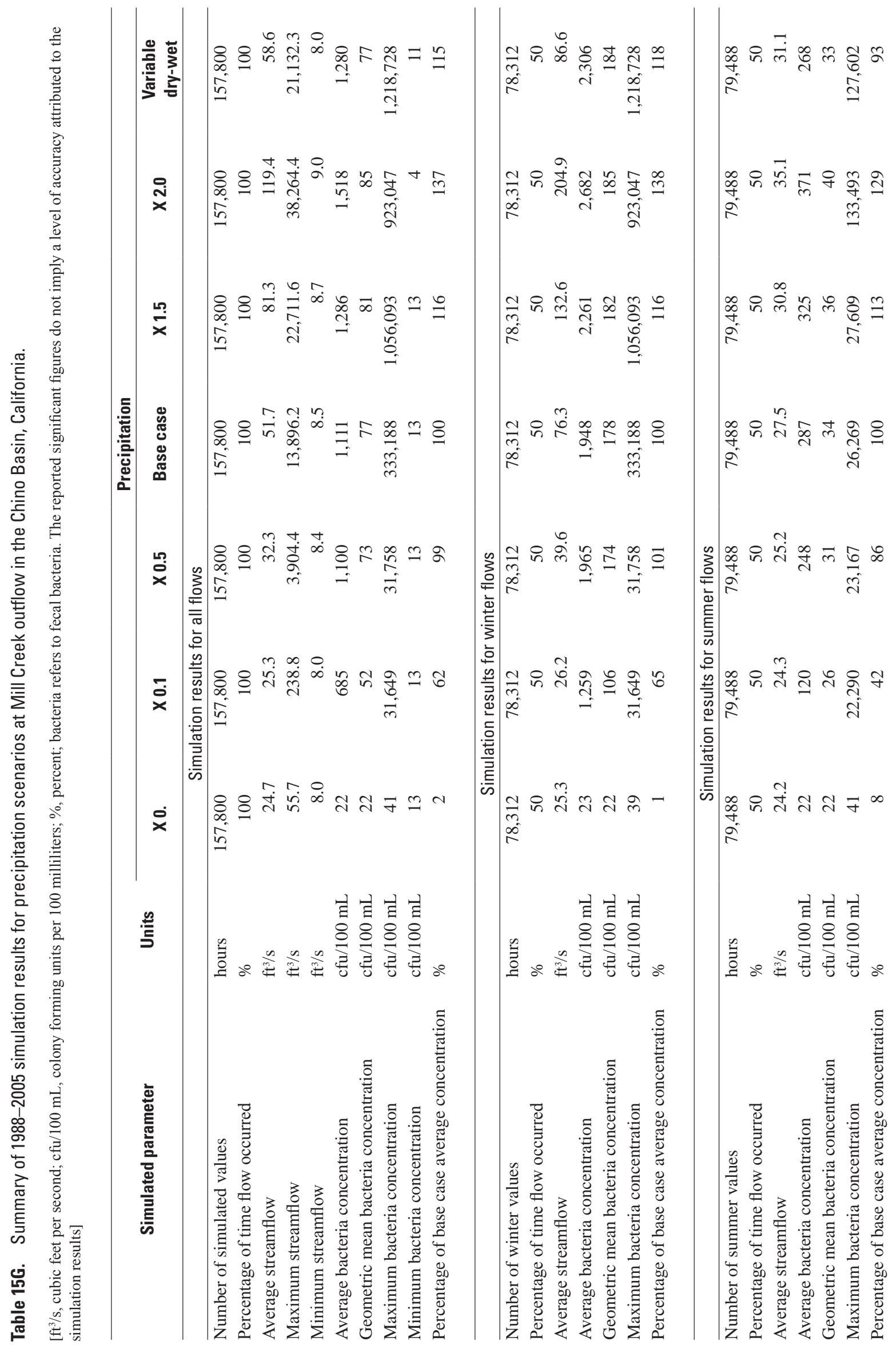




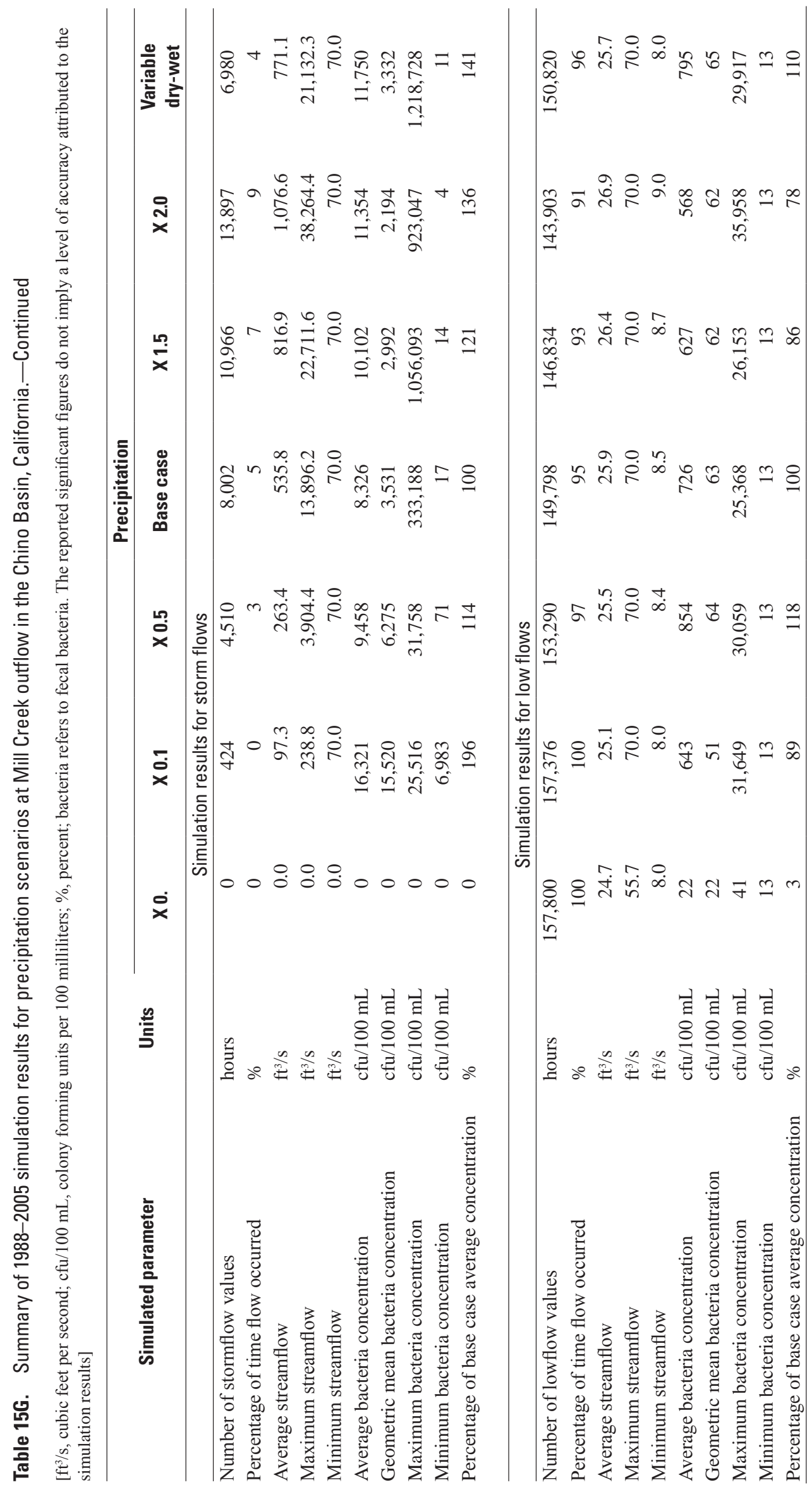


A

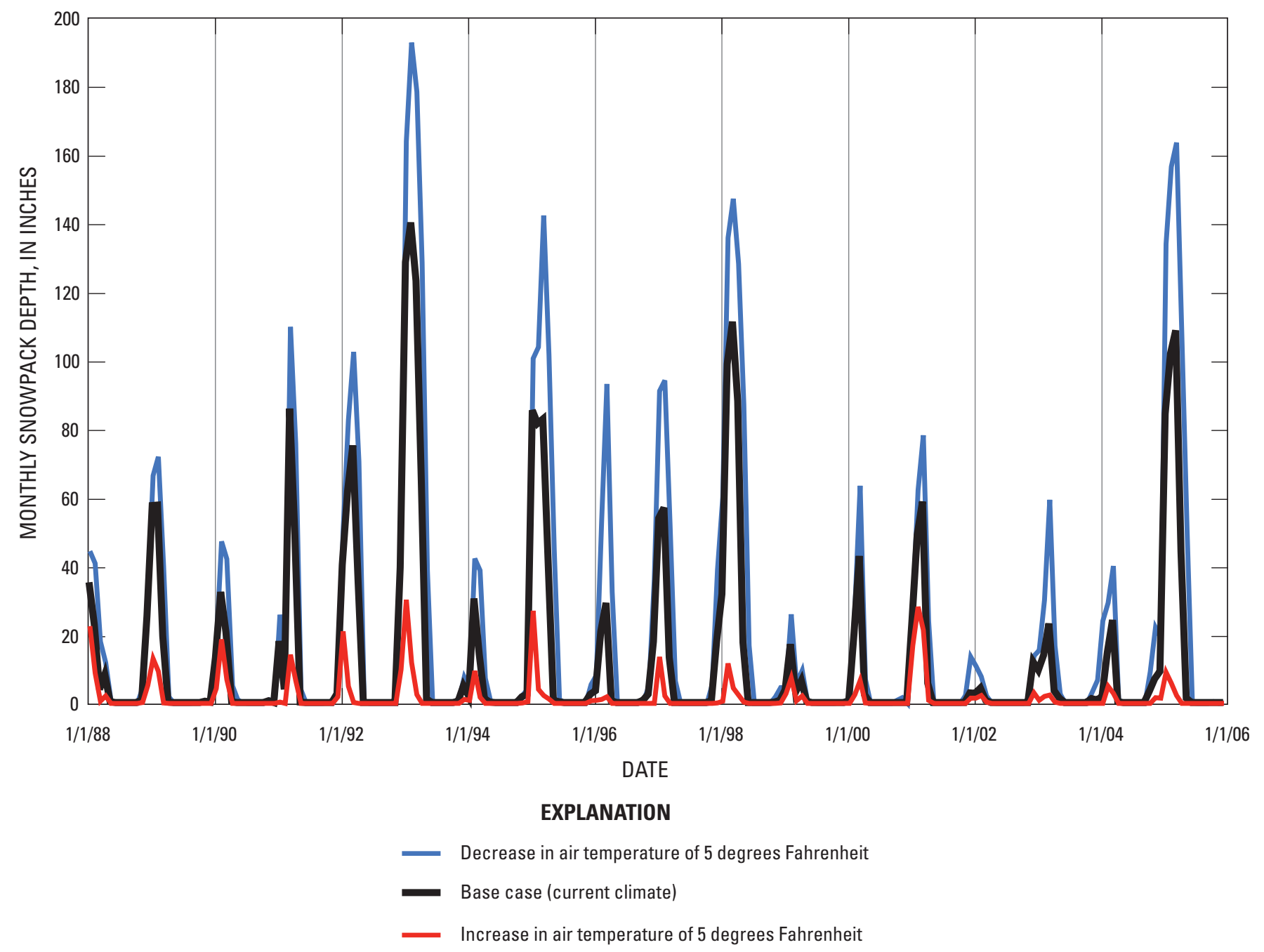

Figure 25. Simulated air temperature scenarios for water-years 1988-2005 at upper San Antonio Canyon in the Chino Basin: $A$, monthly snow pack, $B$, monthly streamflow, and $C$, monthly bacteria concentration.

Simulation results obtained for the outflow at San Antonio Dam indicated a different relationship between air temperature, streamflow, and bacteria concentrations. The increased air temperature scenario resulted in higher peak flows, higher average flows, and higher bacteria concentrations, whereas the lower air temperature scenario resulted in lower peak flows, lower average flows, and lower bacteria concentrations (table 14). The results for the 1988-2005 base case simulation included an average simulated streamflow of $25.9 \mathrm{ft}^{3} / \mathrm{s}$, a maximum streamflow of $1,314 \mathrm{ft}^{3} / \mathrm{s}$, an average bacteria concentration of $121 \mathrm{cfu} / 100 \mathrm{~mL}$, and a maximum bacteria concentration of 2,385 cfu/100 mL. In comparison, results for the increased air temperature scenario included an average streamflow of $49.4 \mathrm{ft}^{3} / \mathrm{s}$, a maximum streamflow of $2,055 \mathrm{ft}^{3} / \mathrm{s}$, an average bacteria concentration of $183 \mathrm{cfu} / 100 \mathrm{~mL}$, and a maximum bacteria concentration of 3,666 cfu/100 mL. Results for the decreased air temperature scenario included an average streamflow of $22.1 \mathrm{ft}^{3} / \mathrm{s}$, a maximum streamflow of $445 \mathrm{ft}^{3} / \mathrm{s}$, an average bacteria concentration of $89 \mathrm{cfu} / 100 \mathrm{~mL}$, and a maximum bacteria concentration of 2,020 cfu/100 mL. 


\section{$\boldsymbol{B}$}

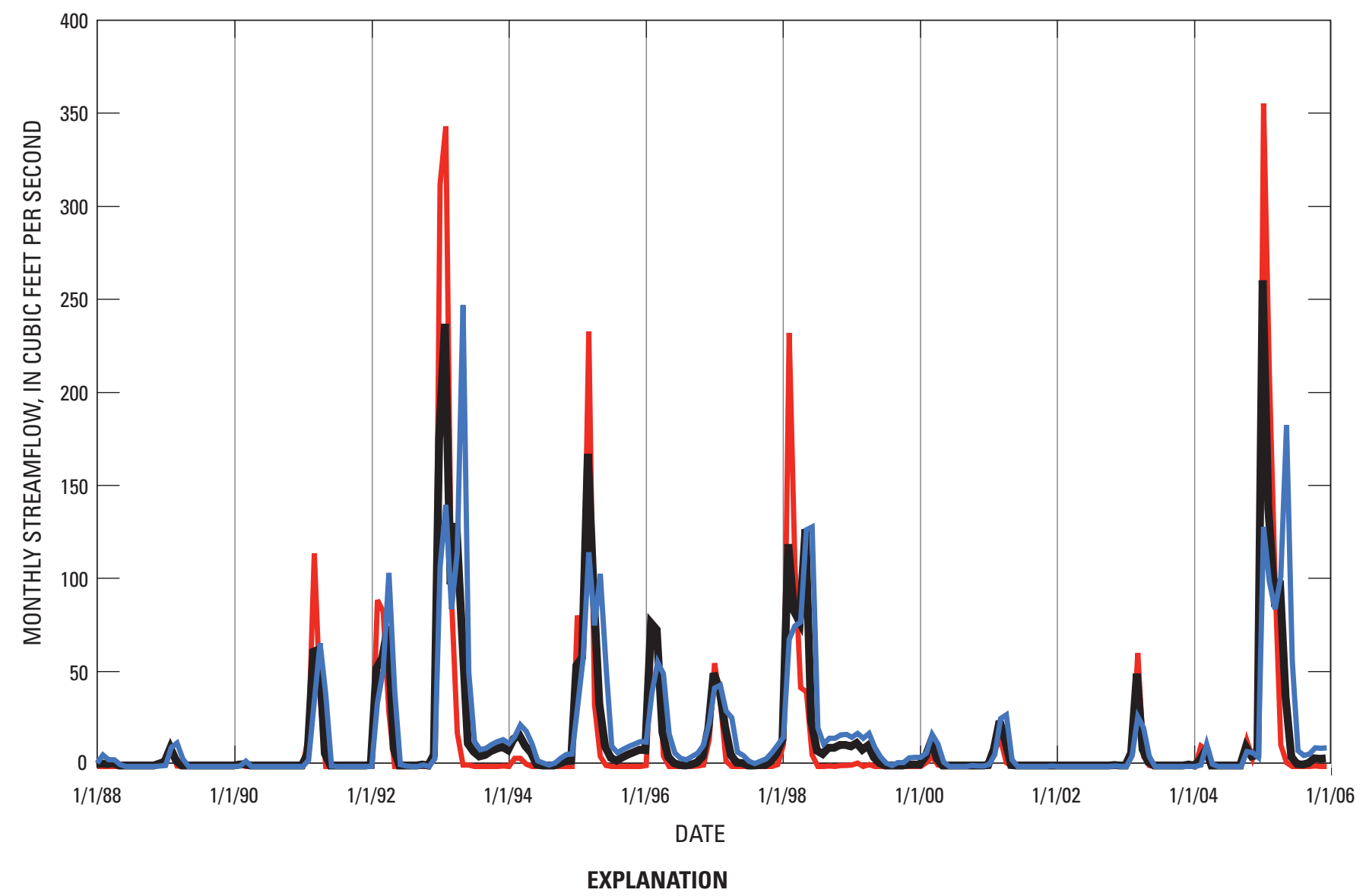

\footnotetext{
Decrease in air temperature of 5 degrees Fahrenheit

Base case (current climate)

Increase in air temperature of 5 degrees Fahrenheit
}

Figure 25. Continued.

The flow duration curves for simulated hourly outflow from San Antonio Dam (based on hourly results for the 1988-2005 simulation period) at temperatures 5 degrees above and below a baseline air temperature- - the two air temperature scenarios-were plotted and compared with the baseline curve. The flow duration analysis indicated that increasing air temperature increased the percentage of time that flows were approximately $100 \mathrm{ft}^{3} / \mathrm{s}$ and greater (fig. 26A) and decreased the percentage of time that smaller flows were less than about $100 \mathrm{ft}^{3} / \mathrm{s}$. Analysis of the decreased air temperature scenario indicated the opposite results: a decrease in the percentage of time that flows were greater than about $200 \mathrm{ft}^{3} / \mathrm{s}$ and an increase in the percentage of time (or number of hours) that flows were $60 \mathrm{ft}^{3} / \mathrm{s}$ or less. The maximum streamflow simulated for the base case was approximately $1,000 \mathrm{ft} / \mathrm{s}$; increasing the air temperature increased the maximum streamflow to about $1,800 \mathrm{ft}^{3} / \mathrm{s}$ and decreasing the air temperature decreased maximum streamflow to only $400 \mathrm{ft}^{3} / \mathrm{s}$. 


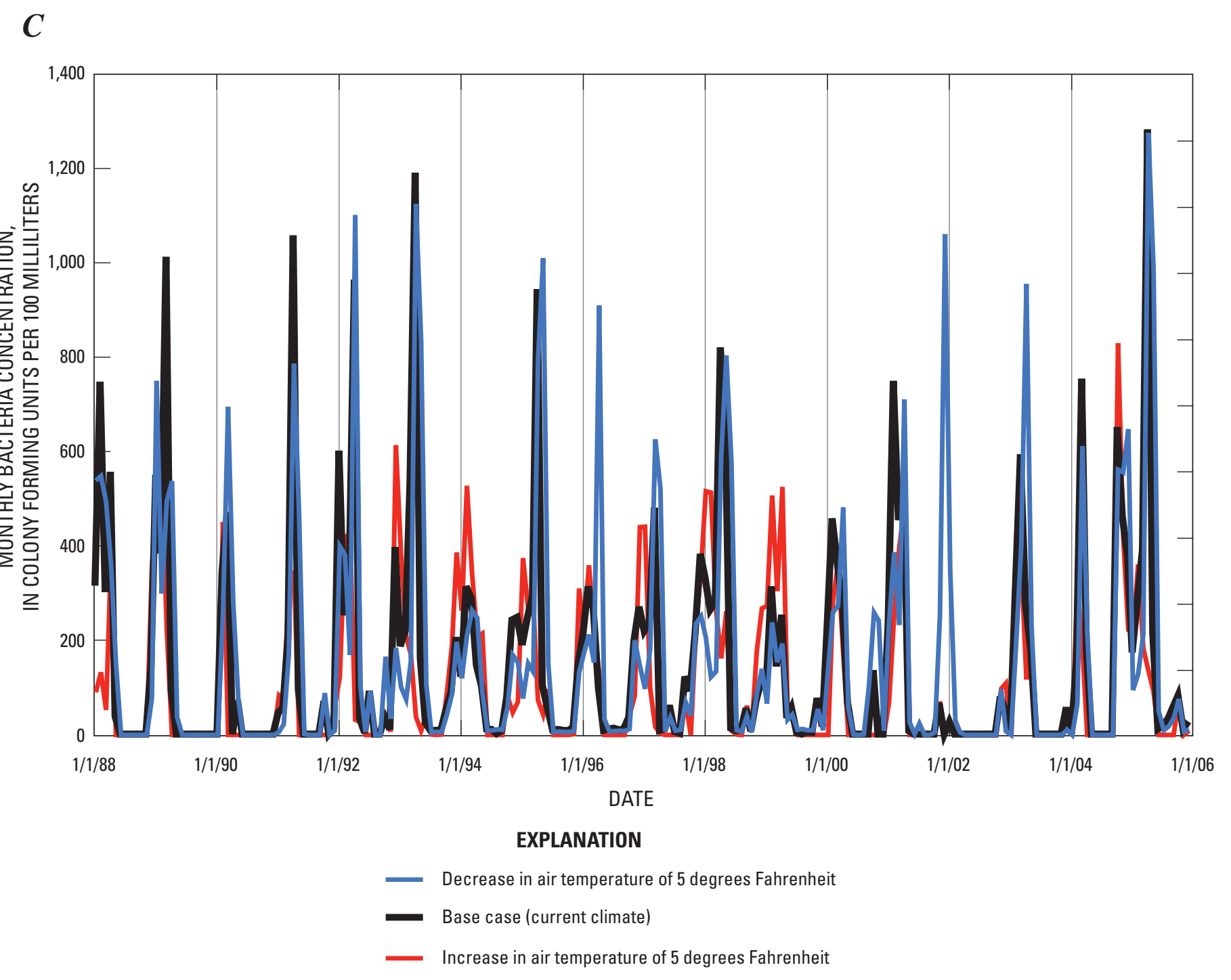

Figure 25. Continued.

The concentration duration analysis of simulated hourly fecal coliform concentrations indicated variations caused by changes in air temperature similar to those of simulated streamflow (fig. 26B). Comparison of concentration durations (percentage of time hourly bacteria concentrations were exceeded) for the increased air temperature scenario and the base case simulation showed a relative difference similar to those for streamflow. Concentration durations for bacteria concentrations of about $200 \mathrm{cfu} / 100 \mathrm{~mL}$ and higher were increased relative to the base case, whereas concentration durations for the low concentrations (about $100 \mathrm{cfu} / 100 \mathrm{~mL}$ and less) were decreased relative to the base case. The results for the decreased air temperature scenario were more similar to the base-case results, with a small decrease in the percentage of time bacteria concentrations were exceeded for concentrations of about $400 \mathrm{cfu} / 100 \mathrm{~mL}$ and higher. The increased air temperature scenario indicated that bacteria concentrations of $200 \mathrm{cfu} / 100 \mathrm{~mL}$ and higher occurred about 3 percent of the time, compared with about 2 percent of the time for the base case and decreased air temperature simulations. 
$\boldsymbol{A}$

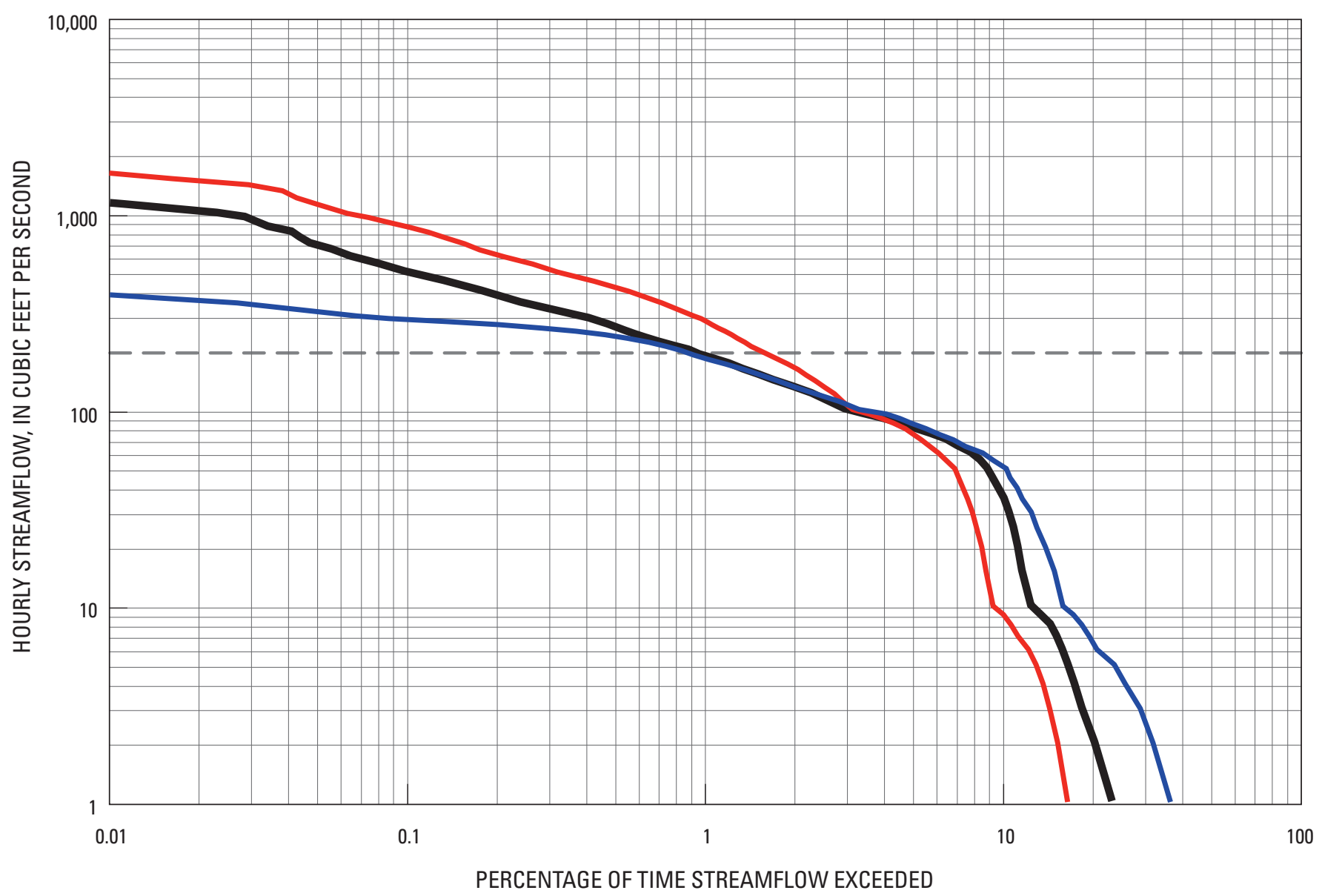

\section{EXPLANATION}

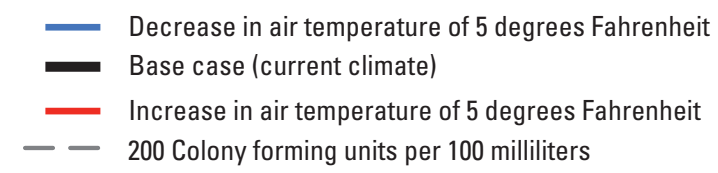

Figure 26. Simulated air-temperature scenarios at San Antonio Dam outflow in the Chino Basin during water-years 1988-2005: $A$, flow duration for hourly streamflow and $B$, concentration duration for hourly bacteria concentrations.

The effects of temperature change on Mill Creek outflow were also analyzed. Although changing the air temperature scenarios significantly affected the results obtained for the San Antonio Canyon subbasin and in the northern part of the Mill Creek subbasin (sample site CCM1), only a small effect was observed in simulation results for Mill Creek outflow (table 14B). The increased air temperature scenario caused a slight increase in average and maximum streamflow, but a slight decrease in average and maximum bacteria concentrations. The decrease in bacteria concentrations was caused by a shift in the timing of peak bacteria concentrations in the outflow from upstream drainages in the San Gabriel Mountains. 
$\boldsymbol{B}$

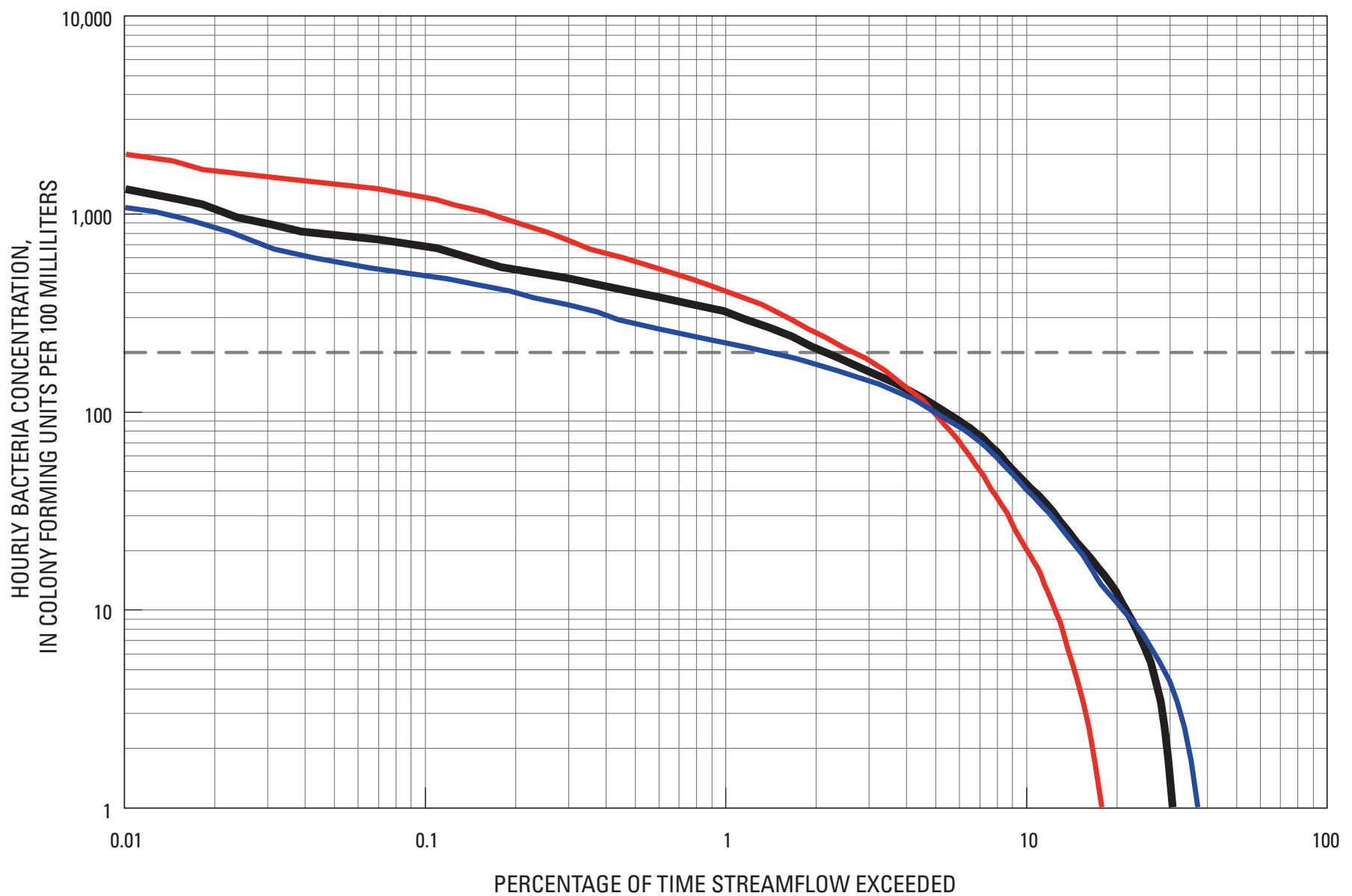

PERCENTAGE OF TIME STREAMFLOW EXCEEDED

\section{EXPLANATION}

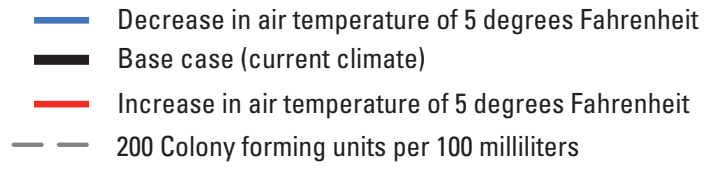

Figure 26. Continued.

\section{Results of Precipitation Scenarios}

Simulated hourly streamflow flow-duration curves for all precipitation scenarios at San Antonio Dam outflow, Chino Creek outflow, and Prado Park Lake outflow are shown in figure 27. Flow duration curves representing the eight precipitation scenarios for the simulated 1988-2005 hourly outflow at San Antonio Dam were compared with the base case (current climate) results (fig. 27A). As expected, changes in precipitation caused significant changes in simulated outflow. Doubling precipitation increased the maximum mean hourly outflow by four times at San Antonio Dam; halving precipitation reduced the outflow to about one-tenth the rate of the base outflow.
Results for Chino Creek outflow indicated similar results in terms of sensitivity to precipitation (fig. 27B ). However, flow-duration analysis indicated that the peak flows for Chino Creek outflow were the most sensitive to changes in precipitation; flows less than about $300 \mathrm{ft}^{3} / \mathrm{s}$ were less sensitive because these flows were strongly controlled by wastewater effluent and OCWD water deliveries in Chino Creek. For example, the percent exceedance for zero precipitation closely matches the percent exceedance for the $0.1 \times$ precipitation scenario because these simulations are dominated by the inflows of wastewater effluent and water deliveries. 


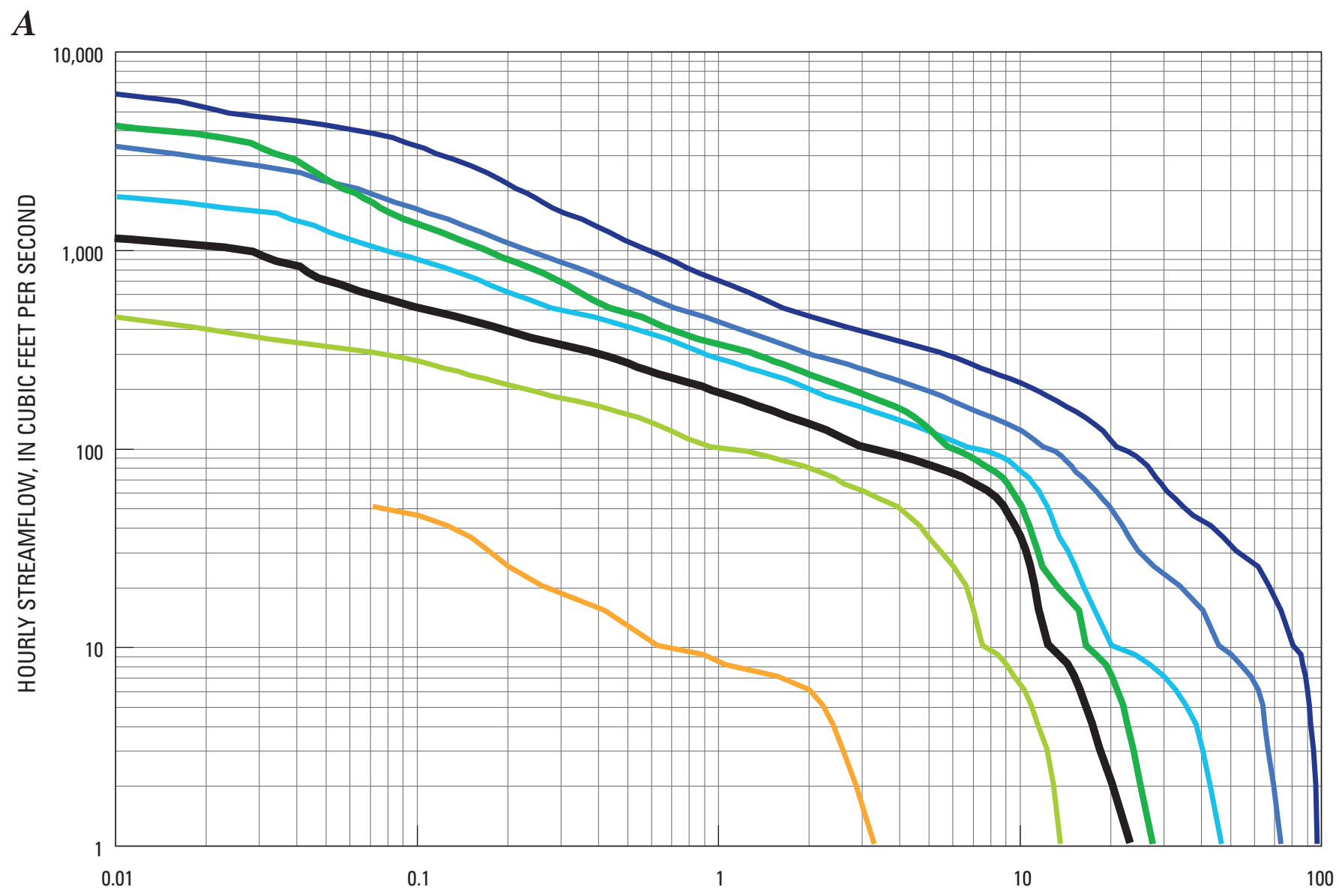

PERCENTAGE OF TIME OUTFLOW EXCEEDED

EXPLANATION

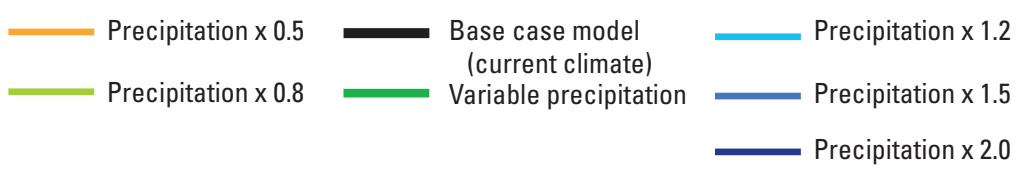

Figure 27. Flow duration of simulated hourly streamflow for precipitation scenarios for water-years 1988-2005 at $A$, San Antonio Dam outflow, B, Prado Park Lake outflow (sample site PPOC), and C, Chino Creek outflow in the Chino Basin, California.

A summary of results for precipitation scenarios at 7 locations is provided in table 15. The simulation results are summarized for all flows, winter flows, summer flows, storm flows, and low flows. At San Antonio Dam outflow, there is no outflow from the Dam and thus no bacteria transport for the 0 scale factor and the $0.1 \times$ precipitation scenarios (table $15 \mathrm{~A}$ ). The $0.5 \times$ precipitation scenario resulted in an average outflow of $5.6 \mathrm{ft}^{3} / \mathrm{s}$, with outflow from the dam occurring 5 percent of time. The base case simulation yielded an average outflow of $25.9 \mathrm{ft}^{3} / \mathrm{s}$, with outflow occurring 46 percent of the time. Maximum outflow for the $2.0 \times$ precipitation scenario was
$7,243 \mathrm{ft}^{3} / \mathrm{s}$, compared with a maximum outflow of $1,314 \mathrm{ft}^{3} / \mathrm{s}$ for the base case. The maximum simulated bacteria concentration was 3,119 cfu/100 mL for the variable dry/wet precipitation scenario. With the exception of the $2.0 \times$ precipitation scenario, maximum bacteria concentrations occurred during low flow conditions for all other scenarios.

Results for sample site D indicate low sensitivity of maximum simulated bacteria concentration to the various precipitation scenarios (table 15B). The maximum concentrations occur during storm and winter flow conditions in all 


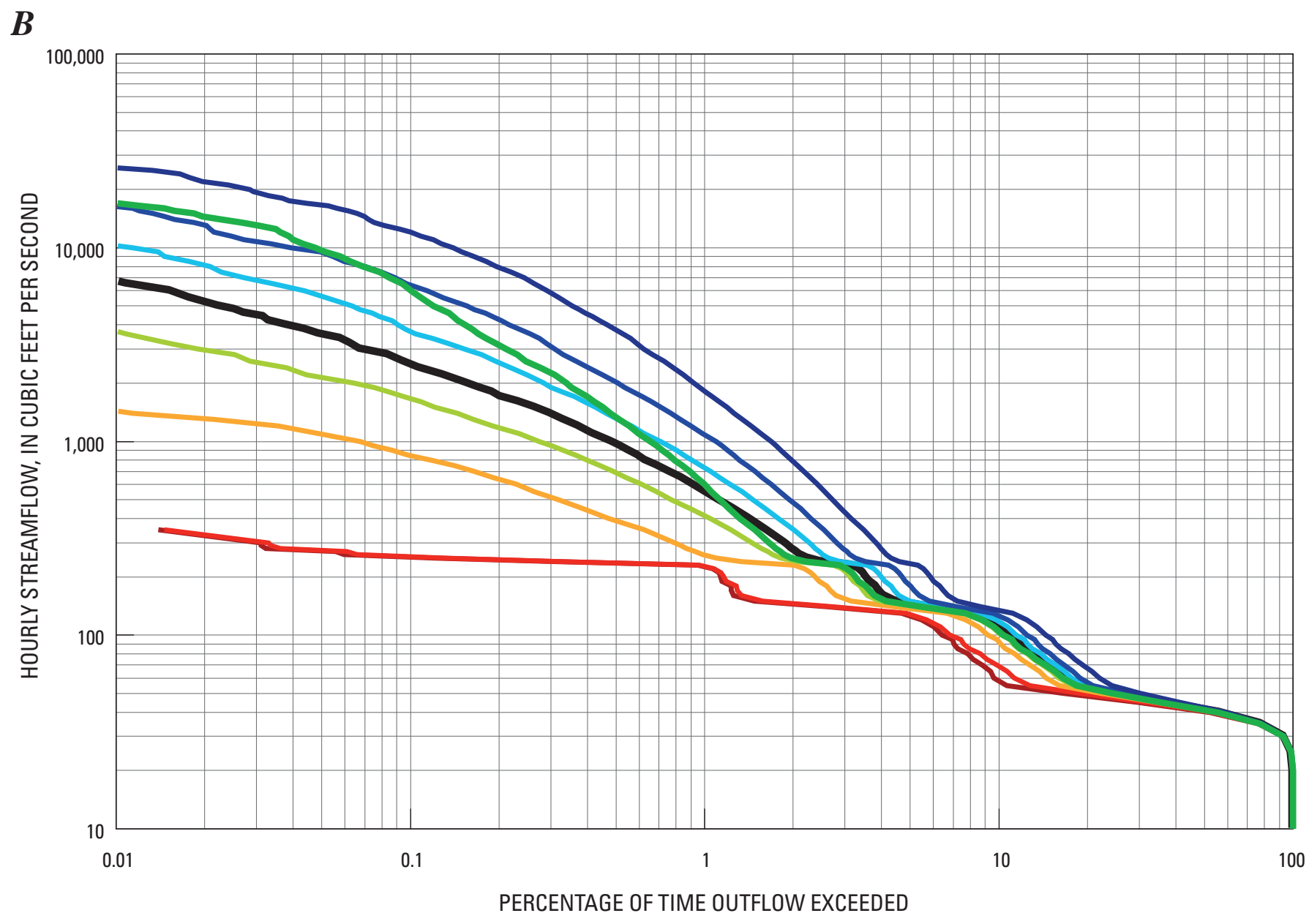

EXPLANATION

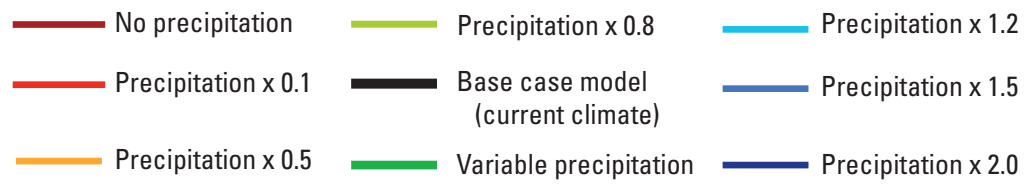

Figure 27. Continued.

cases. Average bacteria concentrations show higher sensitivity and increase from a minimum of $844 \mathrm{cfu} / 100 \mathrm{~mL}$ for the $0 \times$ precipitation scenario (representing only nuisance flow) to a maximum of $13,597 \mathrm{cfu} / 100 \mathrm{~mL}$ for the $2.0 \times$ precipitation scenario. Simulated average streamflow ranges from a minimum of $0.1 \mathrm{ft}^{3} / \mathrm{s}$ (nuisance flow only) to a maximum of $3.2 \mathrm{ft}^{3} / \mathrm{s}$ for the $2.0 \mathrm{x}$ precipitation scenario. The maximum simulated bacteria concentrations at this site are higher than at all other locations simulated for the Chino Basin. The maximum bacteria concentration of 3,559,091 cfu/100 mL was simulated for the $2.0 \mathrm{x}$ precipitation scenario, higher than the maximums of 2,698,312 cfu/100 $\mathrm{mL}$ for the base case and $922 \mathrm{cfu} / 100 \mathrm{~mL}$ for nuisance flow.
Relative differences and responses to increased and decreased precipitation for Prado Park Lake outflow were similar to those for sample site D, but the average and maximum concentrations were much lower than site D because of dilution and die-off processes affecting Prado Park Lake (table 15C). Results of the simulations for this site indicated a strong positive correlation between simulated bacteria concentrations and simulated streamflow (not included in table), and average bacteria concentrations for storm flows were much higher than those for low flows. 
$C$

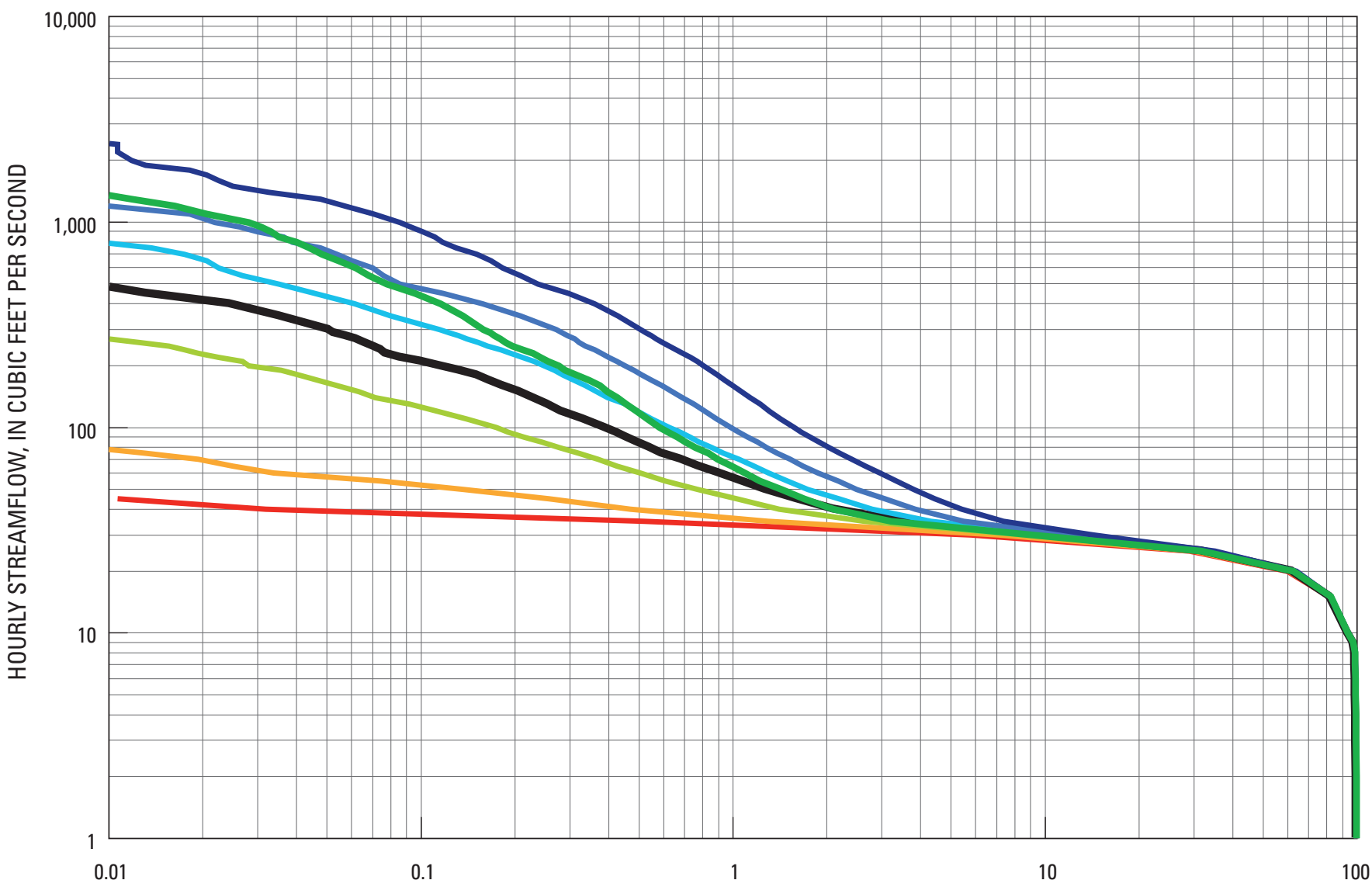

PERCENTAGE OF TIME OUTFLOW EXCEEDED

EXPLANATION
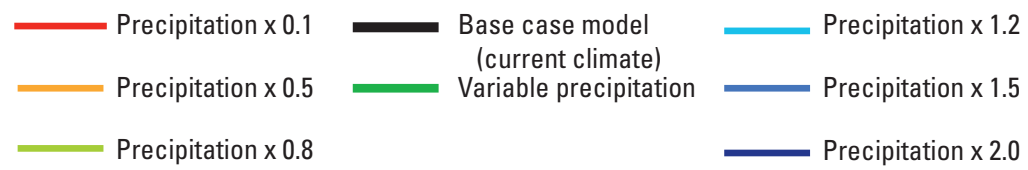

Figure 27. Continued.

Results for Chino Creek outflow also indicated a consistent trend of increasing streamflow and increasing average bacteria concentration with increased precipitation (table 15D). However, results for sites CCM1, CCM2, and Mill Creek outflow indicated a more complex response to the various precipitation scenarios. Sample site CCM1 indicated the expected increase in average and maximum streamflow with increasing precipitation, but the average bacteria concentration was highest for the $0.1 \times$ precipitation climate scenario, and the maximum hourly concentration was highest for the $0.5 \times$ precipitation scenario (table 15E). At CCM2, the average bacteria concentration of 10,545 cfu/100 mL was also highest for the $0.1 \mathrm{x}$ precipitation scenario, and the maximum hourly concentration of $195,891 \mathrm{cfu} / 100 \mathrm{~mL}$ was highest for the base case scenario (prec. x 1.0; table 15F). At Mill Creek outflow, the variation in average bacteria concentrations in response to the different precipitation scenarios was low relative to the other sites, especially for $0.5 \times$ precipitation and wetter scenarios (table 15G).

For most locations and for most scenarios that receive precipitation greater than zero, average simulated bacteria concentrations for winter were greater than average concentrations for summer. Maximum concentrations tended to occur during winter and during storm flows. Average hourly simulated bacteria concentrations during storm flows tended to be greater than average concentrations during low flows. The geometric mean of the hourly concentration was considerably 
less than the average concentration by as much as an order of magnitude or greater. For all flows at most sites, the average simulated concentration exceeded $200 \mathrm{cfu} / 100 \mathrm{~mL}$, whereas the geometric mean concentration was less than $200 \mathrm{cfu} / 100 \mathrm{~mL}$. The highest geometric mean concentrations occurred at sites where nuisance flow is the dominant component of low flow.

Simulated bacteria concentrations tended to increase with increasing precipitation at most sites. Maximum hourly bacteria concentrations often occurred for the variable dry/wet precipitation scenario. Exceptions to these patterns are results for San Antonio Dam outflow, CCM1, and CCM2, where maximum concentrations occur for the $0.1 \mathrm{x}$ precipitation and the $0.5 \times$ precipitation scenarios and increasing precipitation resulted in decreasing concentrations. The overall results illustrate the importance of location and upstream land use on the bacteria transport response to the various climate scenarios.

The concentration duration curves for the various precipitation scenarios at San Antonio Dam outflow indicate a complex relation between precipitation and the distribution of bacteria concentration (fig. 28A). Most of the scenarios resulted in a decrease in the frequency of maximum concentrations relative to the base case simulation. The $0.5 \times$ precipitation scenario produced higher concentrations than the base case at exceedances of 0.1 and less ( 0.1 percent of the time the base case bacteria concentration was exceeded). The $200 \mathrm{cfu} / 100$ $\mathrm{mL}$ concentration was exceeded only 2 percent of the time for the $0.5 \times$ precipitation scenario, compared with about 9 percent for the base case model. The greatest increase in maximum bacteria concentrations resulted from the variable precipitation scenario; maximum concentrations were higher than those for the base case about 0.2 percent of the time and less.

Simulated bacteria concentrations were highly sensitive to the various precipitation scenarios at Prado Park Lake outflow (fig. 28B), but less sensitive at Chino Creek outflow (fig. 28C). At Prado Park Lake outflow, simulated bacteria concentrations affected by 2.0 times the base case precipitation were $3,000 \mathrm{cfu} / 100 \mathrm{~mL}$ or higher 10 percent of the time, compared with about 3 percent of the time for the base case. The $200 \mathrm{cfu} / 100 \mathrm{~mL}$ concentration was exceeded about 0.7 percent of the time for the $0.1 \times$ precipitation scenario, 7 percent of the time for the $0.5 \times$ precipitation scenario, about 12 percent of the time for the base case simulation, and about 20 percent of the time for the $2.0 \times$ precipitation scenario. The relatively high sensitivity of bacteria concentrations to all precipitation scenarios for recurrence probabilities greater than 1 percent was caused by the response of pervious areas in the agricultural land uses. The higher fraction of pervious areas resulted in a higher fraction of upstream area with high loading rates and washoff limits.

Results for the precipitation scenarios at Chino Creek outflow indicated high sensitivity to scenarios drier than that for the base case, but low sensitivity (compared with that for Prado Park Lake outflow) to the scenarios wetter (fig. 28C).
Maximum bacteria concentrations were similar for the $0.8 \mathrm{x}$ precipitation and wetter scenarios relative to the base case simulation at exceedances of about 0.4 percent and less. To compare the effects of precipitation and stormflow with baseflow only (nuisance flow, wastewater effluent, and Orange County water deliveries), the $0 \mathrm{x}$ precipitation scenario (zero precipitation) was included in the concentration-duration analysis. Hourly bacteria concentrations derived from the no precipitation (baseflow only) scenario did not exceed the $200 \mathrm{cfu} / 100 \mathrm{~mL}$ level because the wastewater discharges and Orange County water deliveries dilute the contaminated nuisance flows. The $0.1 \times$ precipitation scenario, which represents extremely dry conditions, caused a very large increase in the maximum simulated concentrations compared to the base case; the $200 \mathrm{cfu} / 100 \mathrm{~mL}$ level was exceeded 15 percent of the time, compared to about 25 percent of the time for the base case. Maximum concentrations were about 30,000 cfu/100 mL for both the 0.1 and $0.5 \times$ precipitation scenarios. Maximum concentration increased to about $120,000 \mathrm{cfu} / 100 \mathrm{~mL}$ for the $0.8 \times$ precipitation scenario. The simulated bacteria concentrations for the drier precipitation scenarios were very sensitive because impervious areas respond quickly to small changes in precipitation during drier conditions; bacteria washoff is initiated in response to small amounts of precipitation because of the lower washoff limits calibrated for the impervious areas. Under the wetter scenarios, the bacteria loading rates for the various land uses limited maximum concentrations, and this reduced sensitivity to the higher precipitation amounts.

\section{Land-Use Scenarios}

Land-use scenarios were used to evaluate the potential effect of land-use changes on basin hydrology and bacteria loading and transport.

\section{Development}

Six different land-use scenarios were developed for comparison with the base case condition. The first land-use scenario (identified as land use scenario 0 ) was defined by setting the bacteria loading for nuisance flows to zero (nuisance flow was simulated as pristine water). The remaining five land-use scenarios were defined by modifying the areas (in acres) of specific land uses contributing to each model reach segment, in addition to setting bacteria loading for nuisance flows to zero. Using uncontaminated nuisance flow allowed a more direct comparison of the effects of the five different land-use changes for all flows because contaminated nuisance flow tended to dominate concentrations simulated for the lower flows. 


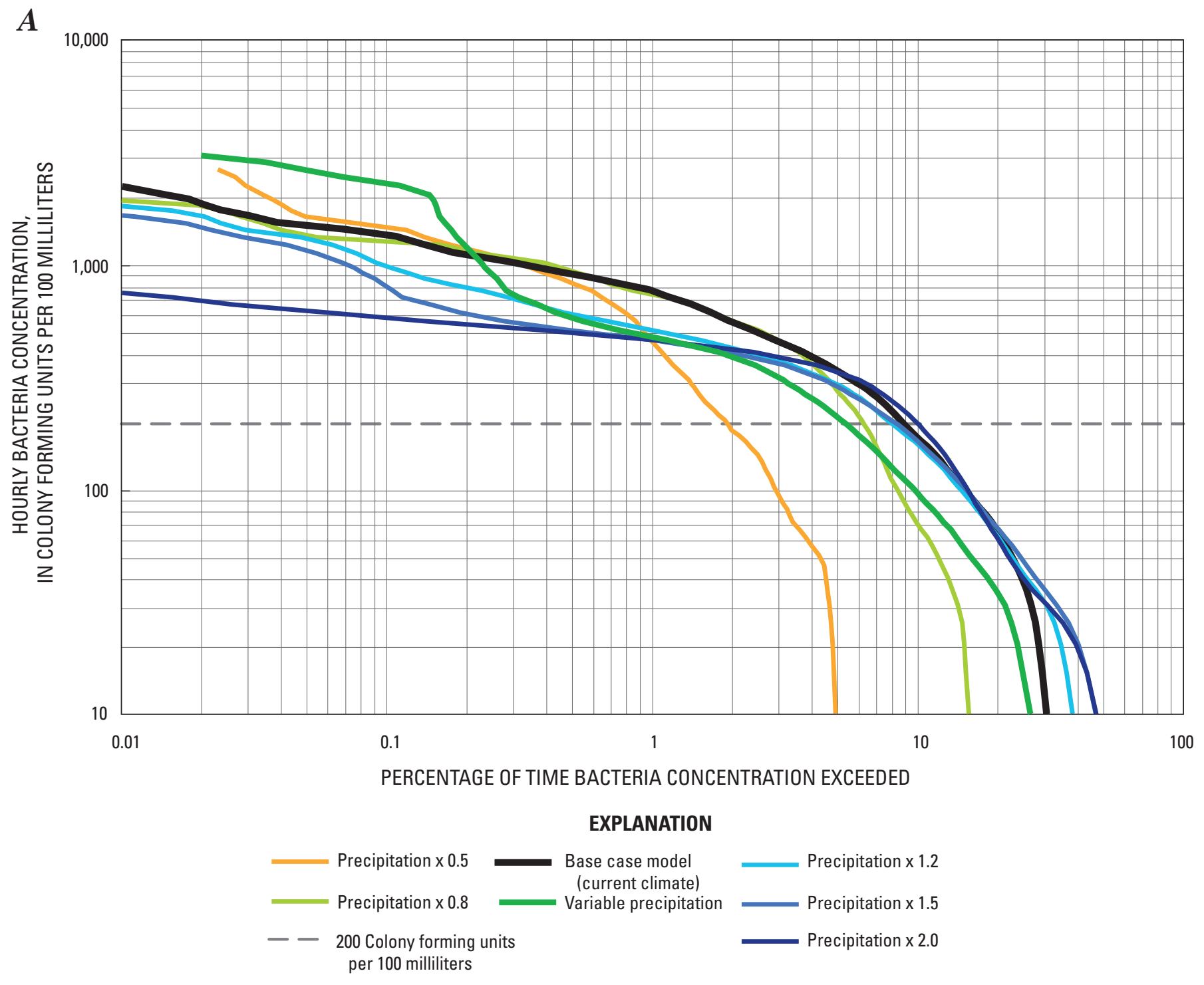

Figure 28. Concentration duration of simulated hourly bacteria concentration for precipitation scenarios for water-years 1988-2005 at $A$, San Antonio Dam outflow, B, Prado Park Lake outflow (sample site PPOC), and C, Chino Creek outflow in the Chino Basin, California.

The land-use modifications were based on the assumptions that residential and recreation and open space land uses would likely increase as mixed agriculture land use (including intensive livestock) and barren or vacant areas decrease. The assumption of increased residential land use was based on recent and projected trends in population growth (Rice, 2005). The assumption of a decrease in mixed agriculture land use, particularly intensive livestock, is supported by recent changes in land use observed in the Chino Basin. Although some increases in commercial and services, industrial, and transportation and utilities land uses are likely with increased population, these changes were not considered in this study. The estimated bacteria loading rate for residential land use was higher than those for all of the other urban land uses and represented an upper bound for the effect of expanding urban areas. The estimated bacteria loading rate for recreation and open-space land use was lower than those for the other urban land uses and represented a lower bound for the effect of increased urbanization at the expense of barren or vacant and mixed agriculture land uses.

Land-use scenario 1 was defined by converting the areas of the barren or vacant land use to the residential land use for each model reach segment (barren or vacant areas in mountainous terrain were not converted to residential). The barren or vacant land-use areas were set to zero. Land-use scenario 2 was defined by converting the intensive livestock land-use area to the residential areas for each model reach segment and setting the area of intensive livestock to zero. All 


\section{$\boldsymbol{B}$}

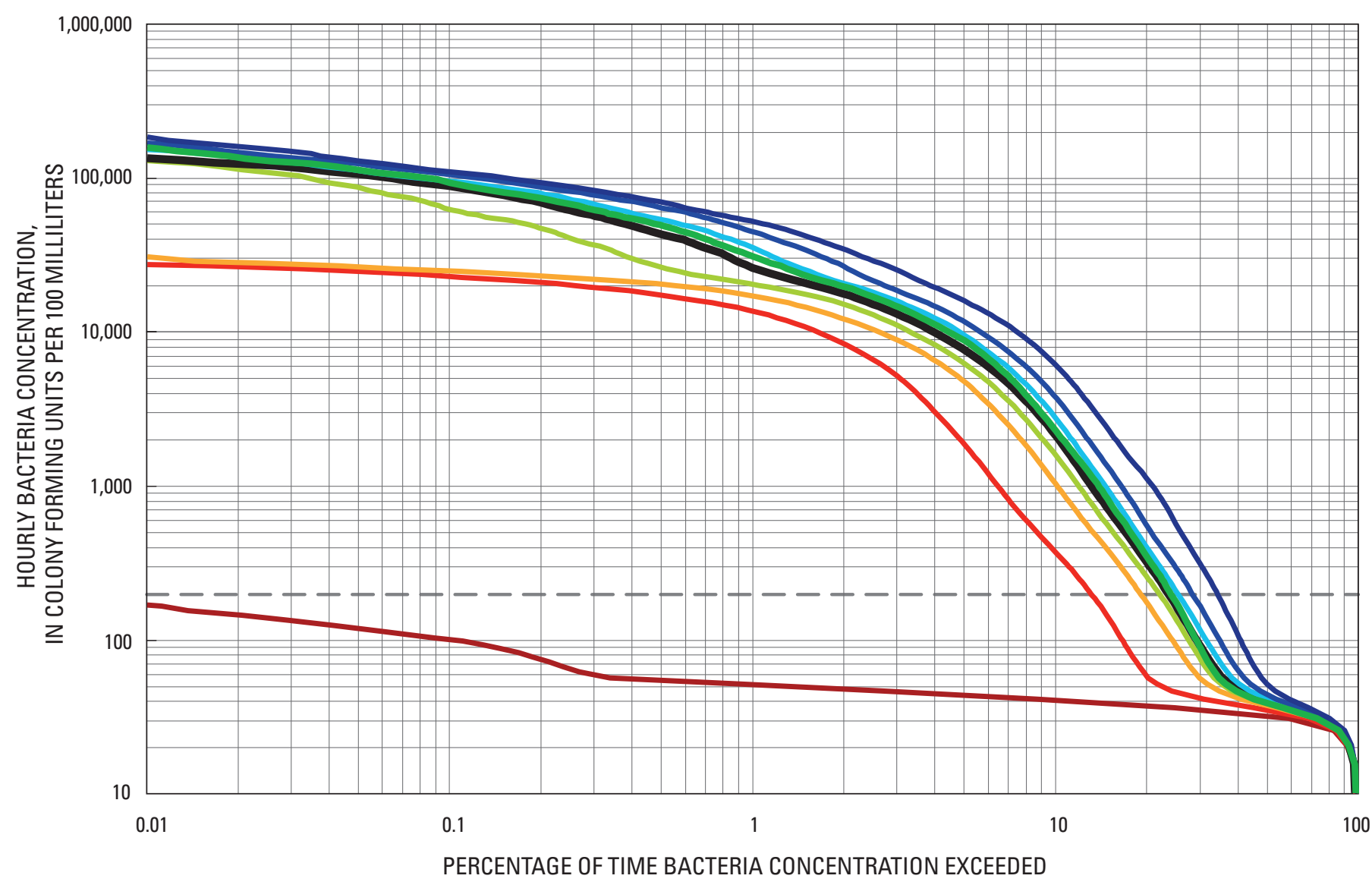

EXPLANATION

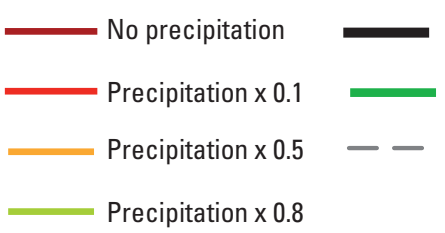

Figure 28. Continued.

land-use areas designated as intensive livestock were set to zero. Land-use scenario 3 was defined by converting all mixed agriculture land-use areas to residential and setting the area of mixed agricultural land use to zero. Land-use scenario 4 was defined by converting barren or vacant areas (excluding barren mountainous areas), intensive livestock, and mixed agriculture land uses to residential. Thus, land-use scenario 4 was defined by combining modifications of land-use scenarios 1 through 3. Land-use scenario 4 represents the full expansion of the residential land use into the likely areas for population growth in the Chino Basin area. Land-use scenario 5 was defined by converting barren or vacant areas (excluding barren mountainous areas), intensive livestock, and mixed agriculture land uses to recreation and open space land uses.
By converting the various land-use areas to residential or recreation and open space land use, the balance between pervious and impervious areas was also modified to preserve the ratio of pervious to impervious areas defined for the different land uses. This resulted in a decrease in pervious area and an increase in impervious area for land-use scenarios 1 through 4. Land-use scenario 1 (converting barren or vacant to residential) resulted in an increase in the estimated non-point source bacteria accumulation and storage terms relative to the base case, whereas land-use scenarios 2, 3, 4, and 5 all resulted in a decrease in the estimated non-point source bacteria accumulation and storage terms relative to the base case. 
C

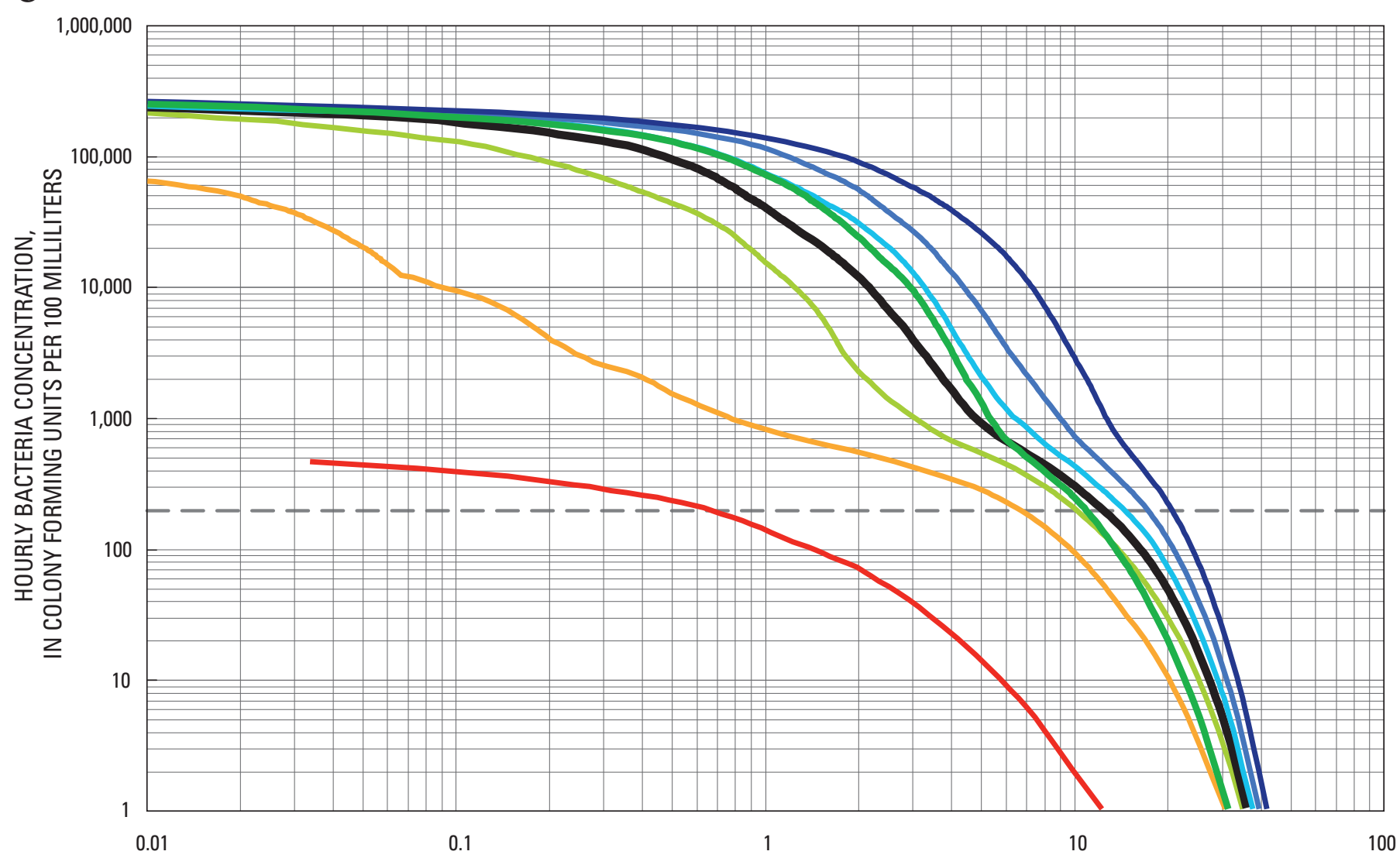

PERCENTAGE OF TIME BACTERIA CONCENTRATION EXCEEDED

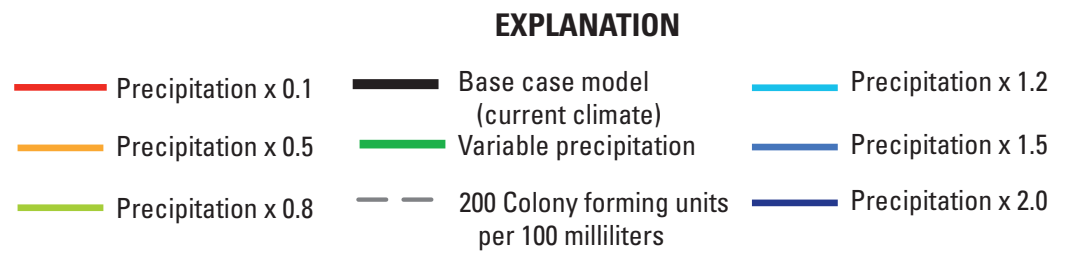

Figure 28. Continued.

\section{Results of Land-Use Scenarios}

Simulation results for the various land-use scenarios were evaluated and compared to the base case result for four locations throughout the Chino Basin study area: (1) sample site D, (2) Prado Park Lake outflow, (3) Chino Creek outflow, and (4) Mill Creek outflow (table 16). The greatest differences between the various land-use scenarios resulted from simulating sample site D (table 16A) and Prado Park Lake outflow (table 16B); the smallest differences occurred at Mill Creek outflow (table 16D). Sample site D and Prado Park Lake outflow were the most sensitive because the amount of upstream land area affected by the land-use changes was greatest for the Prado Basin subwatershed, which includes the Euclid Avenue subwatershed upstream of sample site D. 


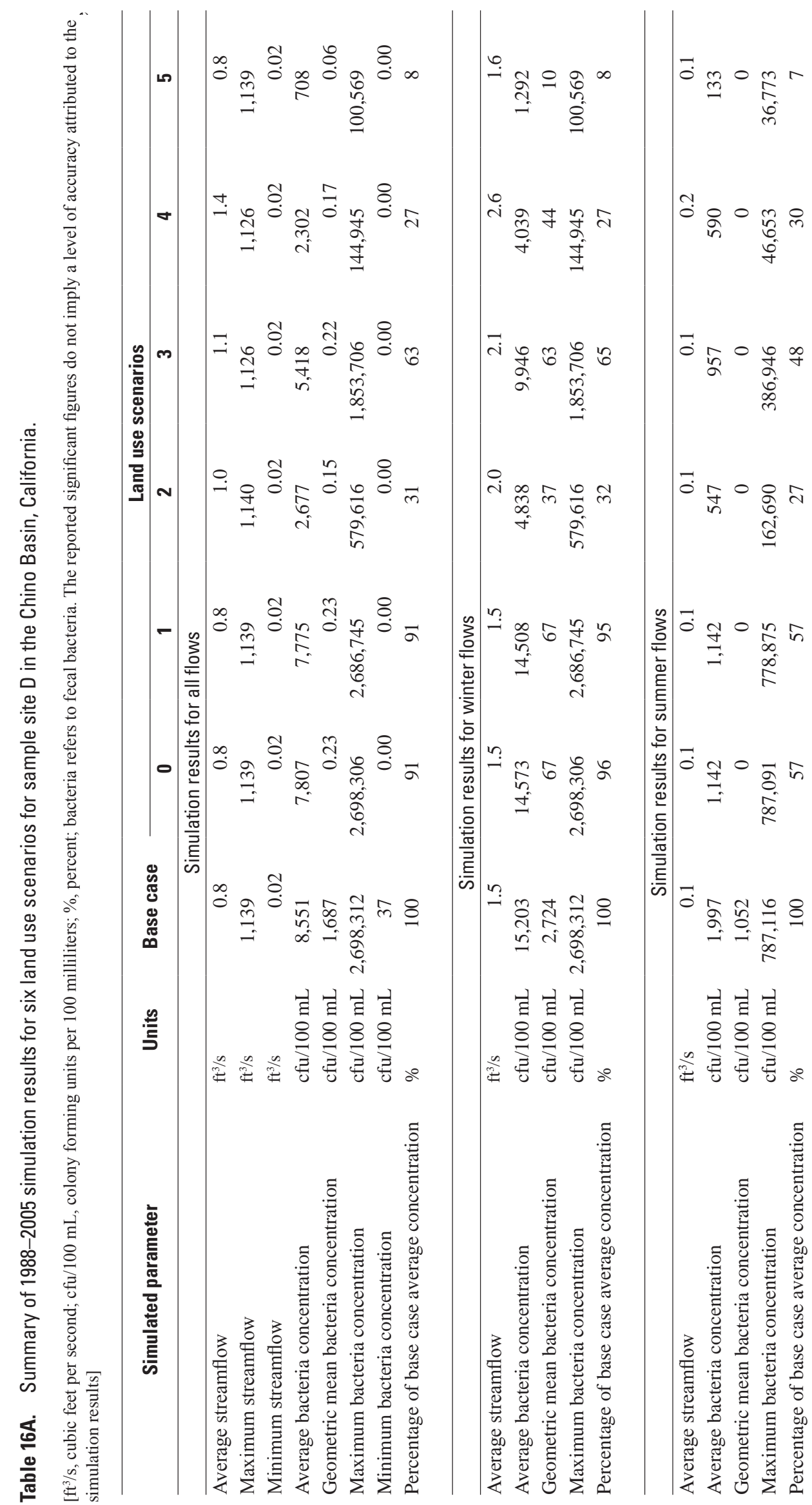




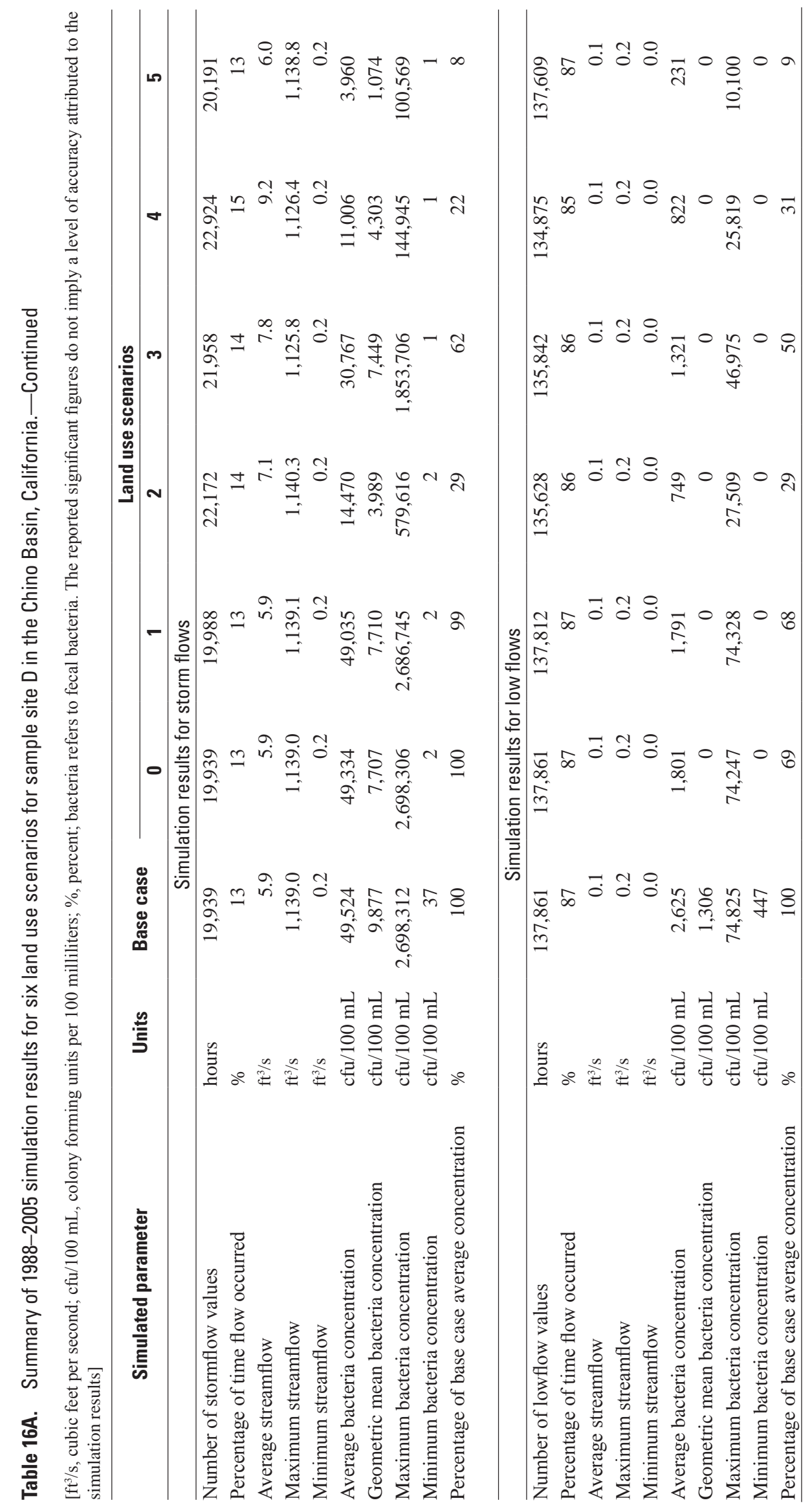




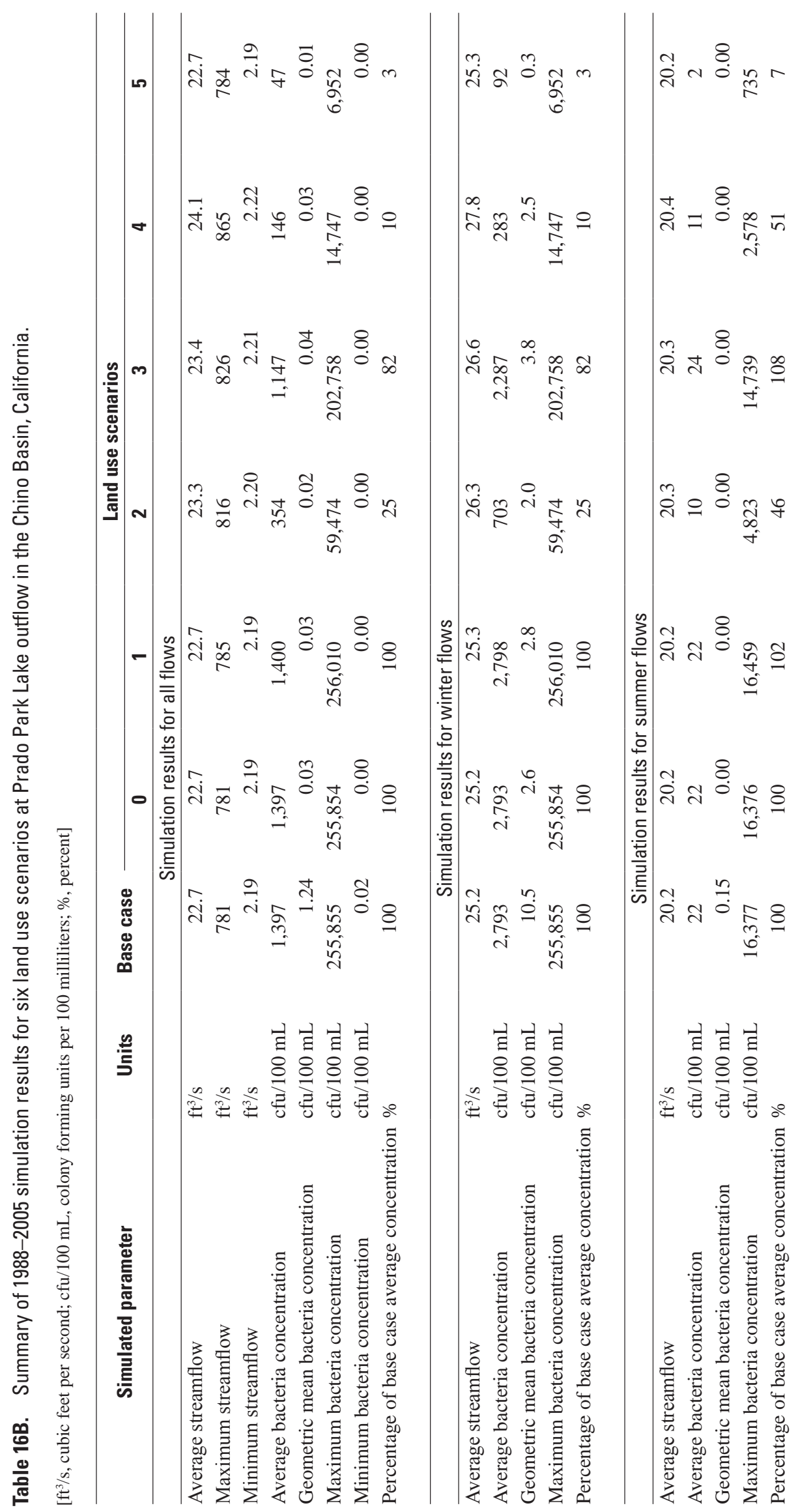




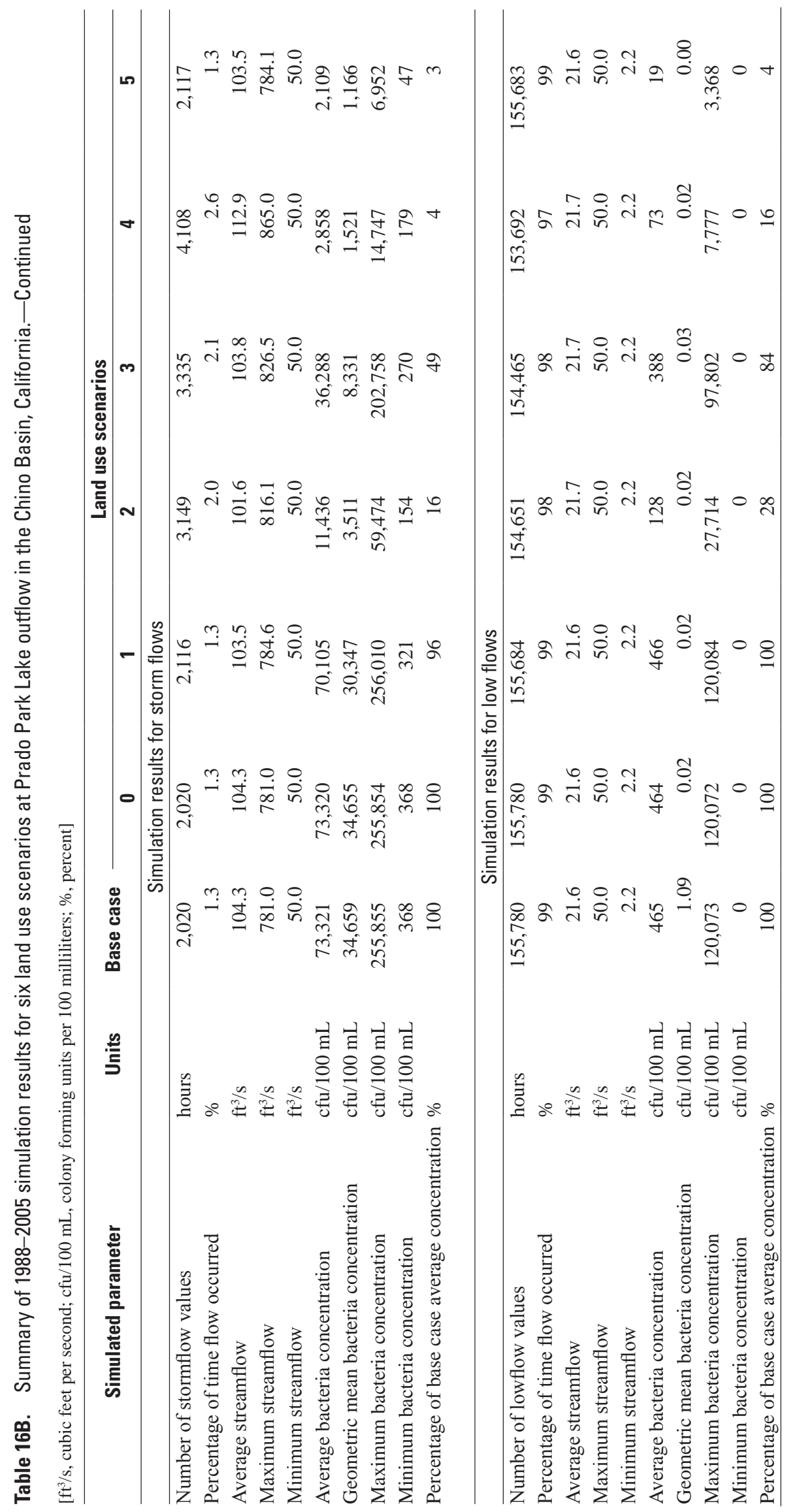




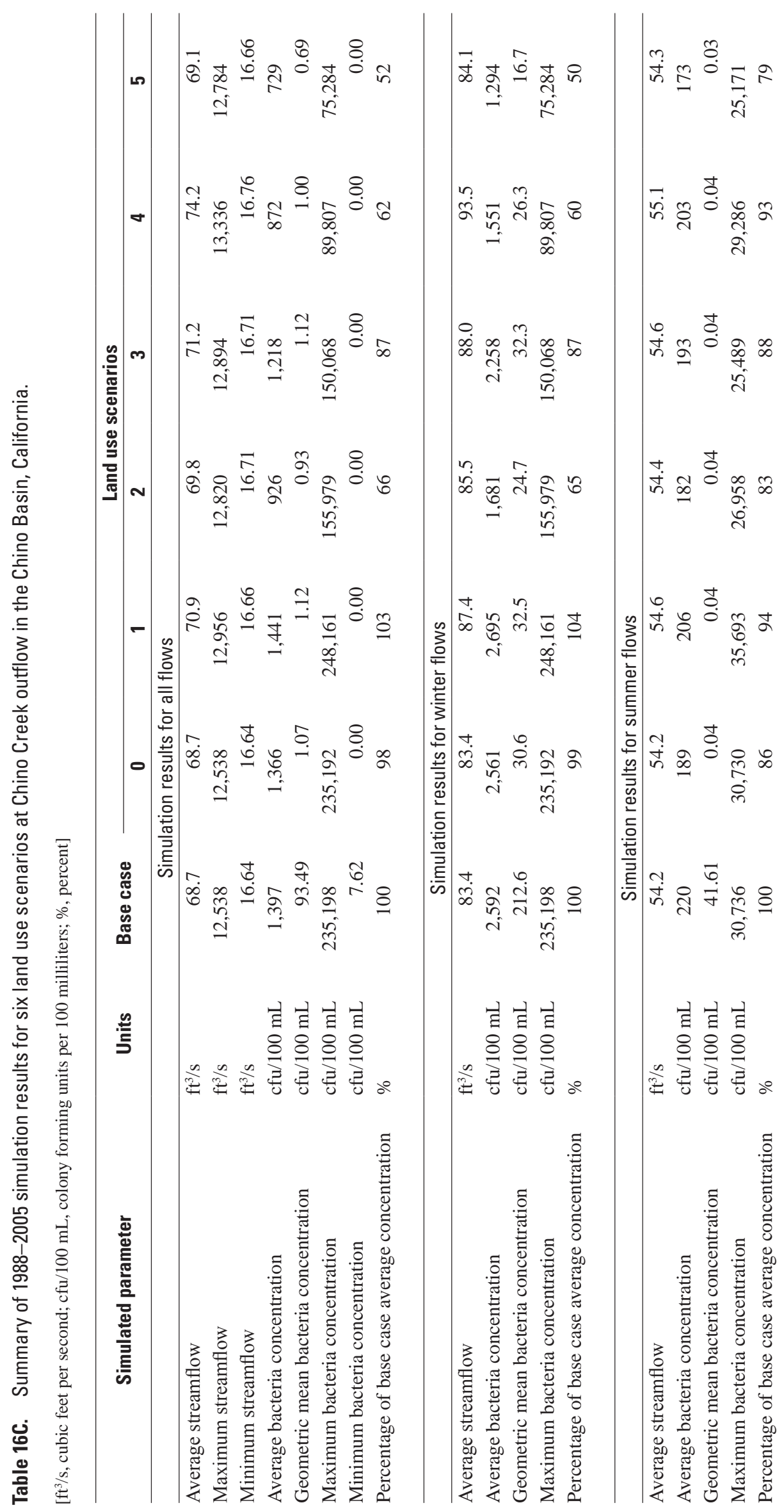




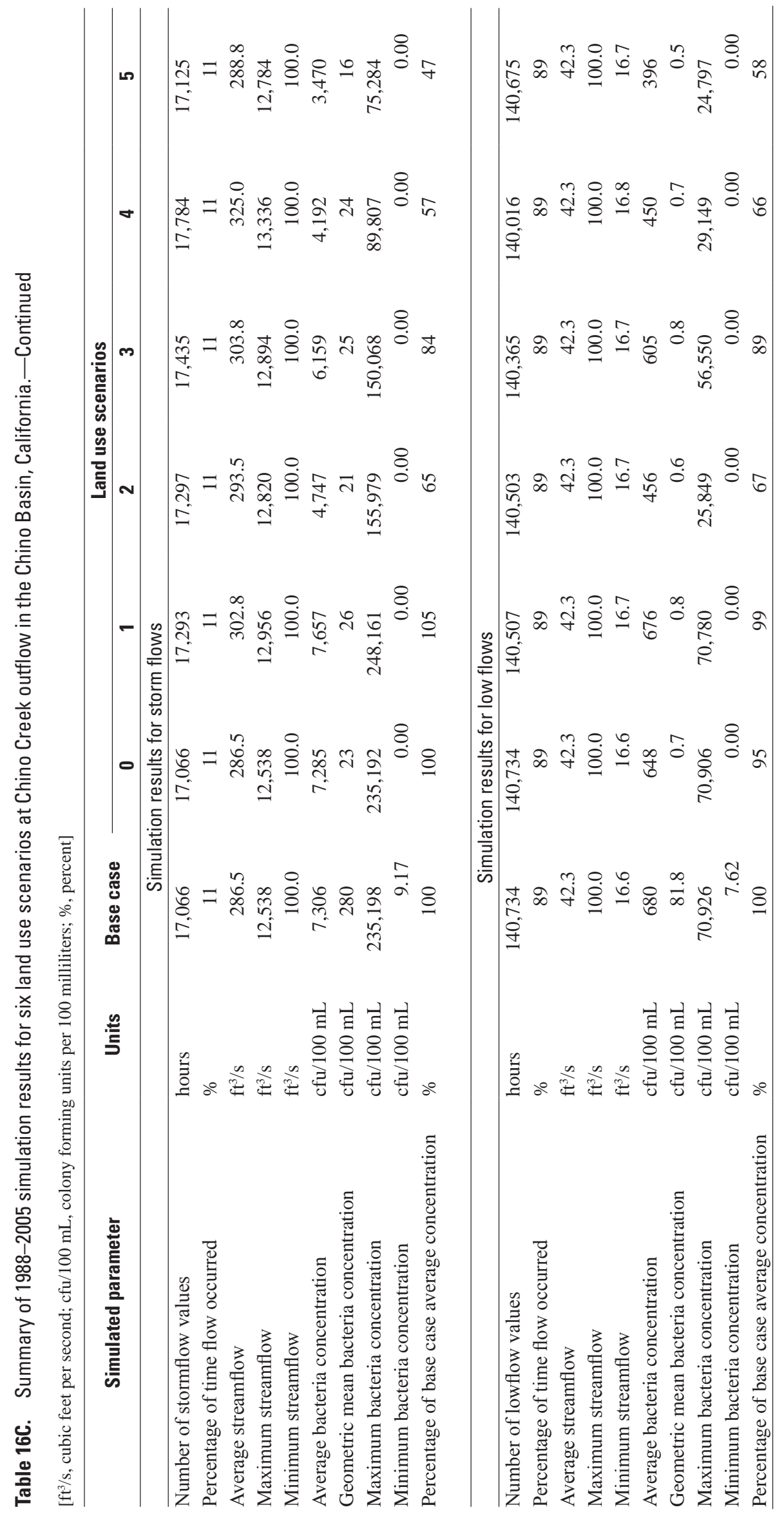




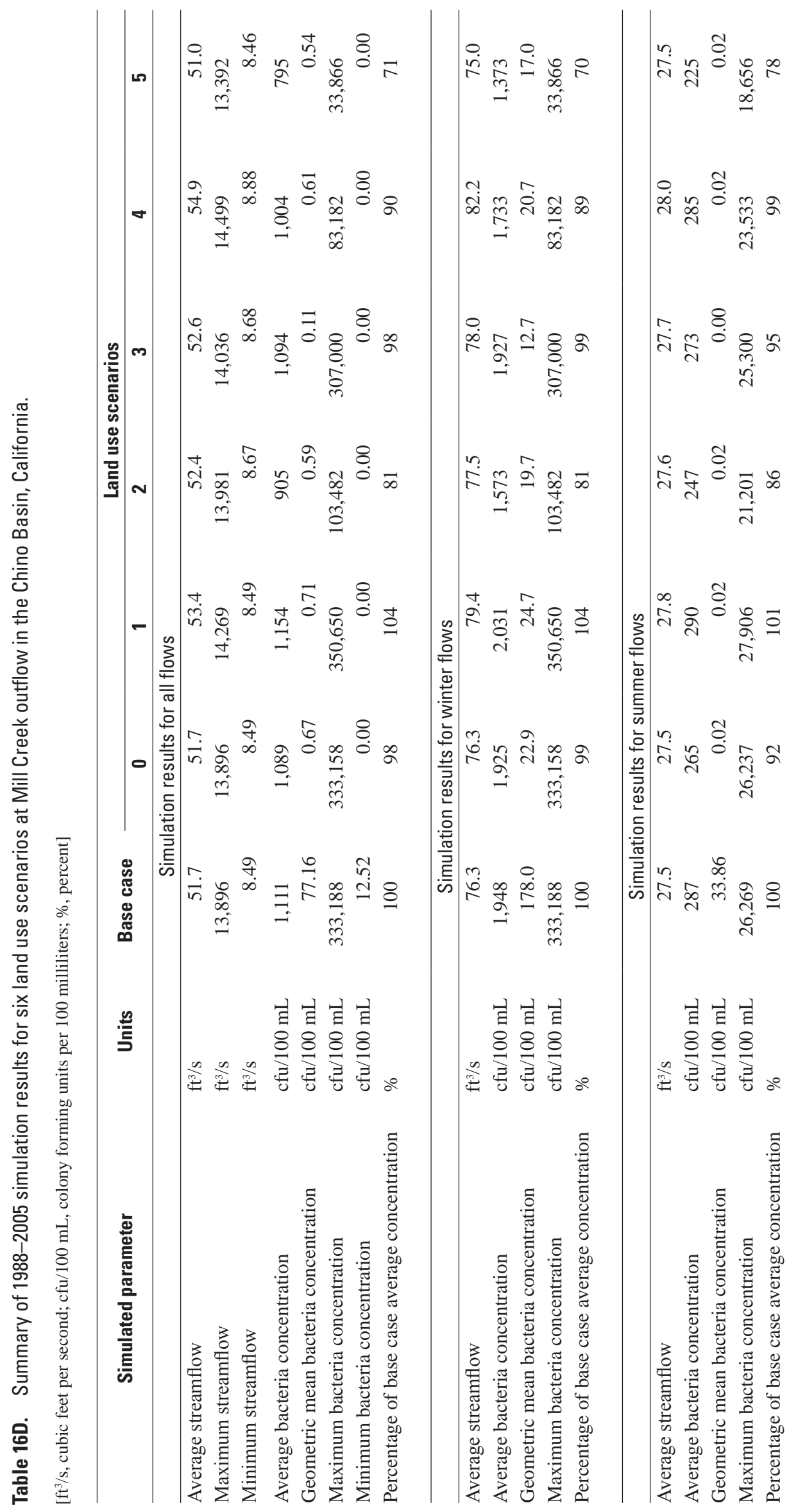




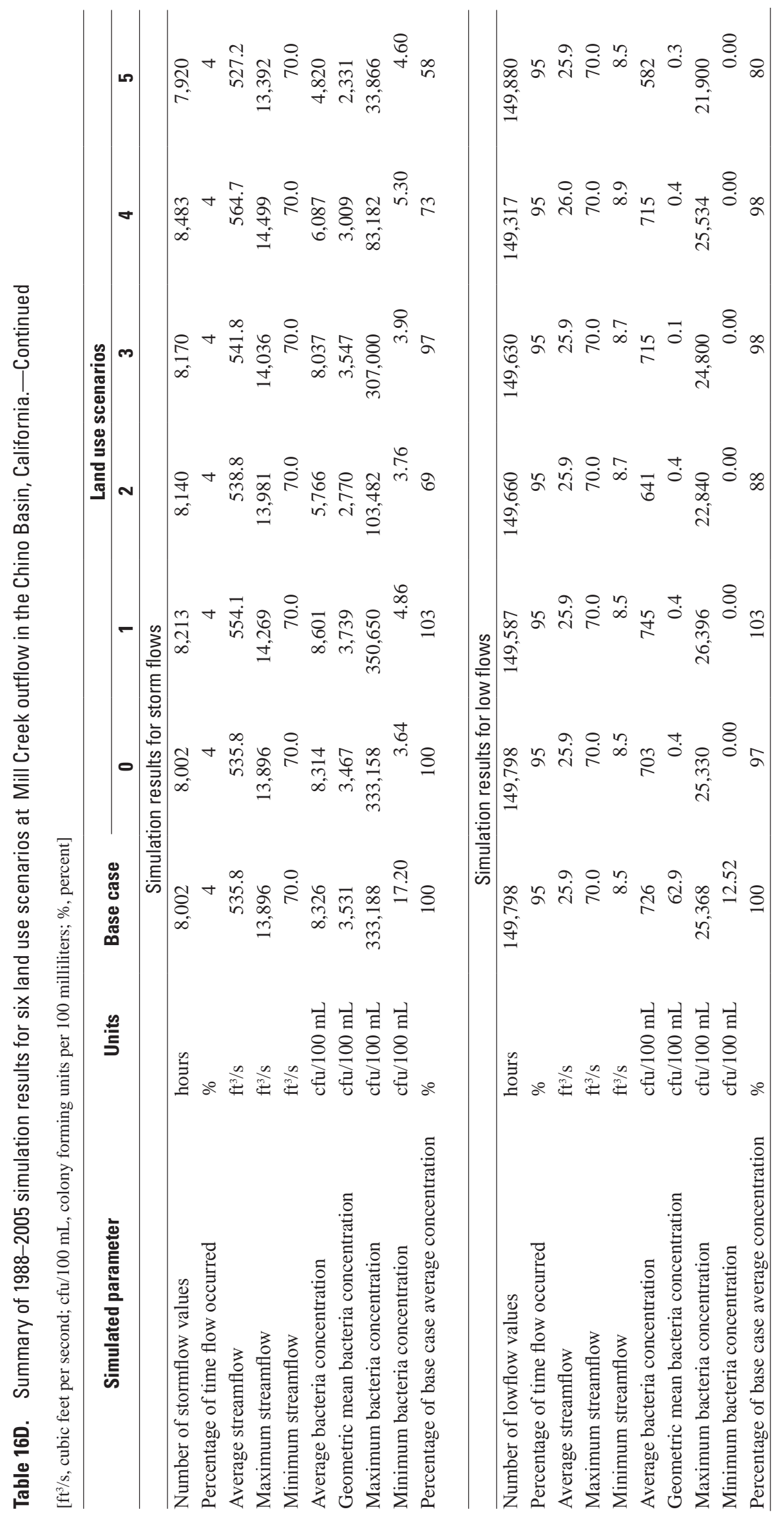


Changing from contaminated to pristine nuisance flow (scenario 0) reduced the average bacteria concentration (for all flows) at site $\mathrm{D}$ from $8,551 \mathrm{cfu} / 100 \mathrm{~mL}$ to $7,807 \mathrm{cfu} / 100 \mathrm{~mL}$, a decrease of about 9 percent (table 16A). The geometric-mean bacteria concentration was reduced from $1,687 \mathrm{ft} 3 / \mathrm{s} / 100 \mathrm{~mL}$ to about zero; however, there was no significant affect on the maximum bacteria concentration. Land-use scenario 4 reduced the average concentration substantially to $2,302 \mathrm{cfu} / 100 \mathrm{~mL}$, a 73 percent reduction from the base case. The largest reduction (and thus improvement) was caused by land-use scenario 5, which reduced the average concentration to $708 \mathrm{cfu} / 100 \mathrm{~mL}$, a 92 percent reduction. Relative changes in simulated maximum hourly concentrations were greater than relative changes in the average concentrations; the lowest maximum concentration at site D under land-use scenario 5 was 100,569, compared with the highest maximum concentration of about 2.7 million $\mathrm{cfu} / 100 \mathrm{~mL}$ for the base case. The greatest improvement in water quality for a land-use scenario involving a change in only one land use (scenarios 1-3) was simulated for land-use scenario 2, which resulted in a 69 percent reduction in average concentration.

Results for Prado Park Lake outflow were similar to results obtained for site $\mathrm{D}$, but indicated an even greater relative reduction in average and maximum bacteria concentrations (table 16B). The average bacteria concentration for land-use 5 was $47 \mathrm{cfu} / 100 \mathrm{~mL}$ compared with the average concentration of 1,397 cfu/100 mL for the base case, a reduction of 97 percent. The maximum concentration was reduced from $255,855 \mathrm{cfu} / 100 \mathrm{~mL}$ for the base case to $6,952 \mathrm{cfu} / 100$ $\mathrm{mL}$ for land-use scenario 5. Stormflow bacteria concentrations for Prado Park Lake outflow were several orders of magnitude higher than low flow concentrations for all land-use scenarios.

Results for the various land-use scenarios at Chino Creek outflow indicated a diminished response to the landuse scenarios compared to the affect of the scenarios on the Prado Basin. Simulation of pristine nuisance flow (land-use scenario 0 ) resulted in only a 2-percent reduction in the average bacteria concentrations, and no reduction in the maximum hourly concentration. Results based on land-use scenario 2 indicated a 34-percent reduction in the average bacteria concentration. Land-use scenario 4 provided a 3-percent reduction in the average bacteria concentration, while results for land-use scenario 5 indicated a 48-percent reduction. As with the other sites, the greatest improvement in water quality was simulated using land-use scenario 5 ; the maximum hourly bacteria concentration of 235,198 cfu/100 mL obtained for the base case was reduced to $75,284 \mathrm{cfu} / 100 \mathrm{~mL}$.

Land-use scenarios applied to the Mill Creek subbasin generally resulted in smaller changes in simulated bacteria concentrations at Mill Creek outflow compared with those for the locations simulated for the Chino Creek subbasin (table 16D). Land-use scenario 4 resulted in a 4-percent decrease in average bacteria concentrations. Land-use scenario 5 resulted in only a 29-percent reduction in average bacteria concentration. A much greater relative reduction was obtained in the simulated maximum hourly concentrations. The maximum concentration obtained using land-use scenario 5 is $33,866 \mathrm{cfu} / 100 \mathrm{~mL}$, about one-order of magnitude lower than the simulated maximum concentration of 333,188 cfu/100 mL for the base case.

Comparisons of simulated daily streamflow and bacteria concentrations during storms for the five land-use scenarios at Prado Park Lake outflow (sample site PPOC), Chino Creek outflow, and Mill Creek outflow during 12/24/2004-3/8/2005 are shown in figures $29 A-C$. The base case model with pristine nuisance flow is equivalent to land-use scenario 0 discussed previously. Results for Prado Park Lake outflow indicate a relatively simple relation between peak streamflow and peak bacteria concentration, although peak bacteria concentrations for land-use scenarios 4 and 5 are much lower than peak streamflow (fig. 29A). Results for Chino Creek outflow indicate a more complicated response; differences between land-use scenarios were relatively small for the smaller storm peaks, but much greater for the simulated stormflows greater than approximately $100 \mathrm{ft}^{3} / \mathrm{s}$ (fig. 29B). The smaller stormflows were affected less by outflow from Prado Park Lake, and differences in concentrations represented the effect of changes in land use in other parts of the Chino Creek subbasin. The larger streamflows included a significant contribution from Prado Basin, and these flows reflect the much higher sensitivity to the changes in land use, as compared to runoff generated in other parts of the Chino Creek subbasin. Results for Mill Creek outflow indicated a more complicated and variable relation between bacteria concentration and streamflow compared to the results obtained for both the Chino Creek and Prado Park Lake outflows (fig. 29C). The results for Mill Creek outflow indicated much higher bacteria concentrations (greater than $45,000 \mathrm{cfu} / 100 \mathrm{~mL}$ ) for the $2 / 26 / 2005 \mathrm{storm}$ relative to concentrations for the other storms (less than 20,000 cfu/100 $\mathrm{mL}$ ), including the $1 / 10 / 2005$ storm with a higher peak flow compared to the $2 / 26 / 2005$ storm. The earlier storms in the storm sequence, including the 1/10/2005 storm, created antecedent conditions that resulted in saturated soils and increased runoff generation from the mixed agriculture and intensive livestock PERLNDs that are affected by the land-use scenarios. 
$\boldsymbol{A}$

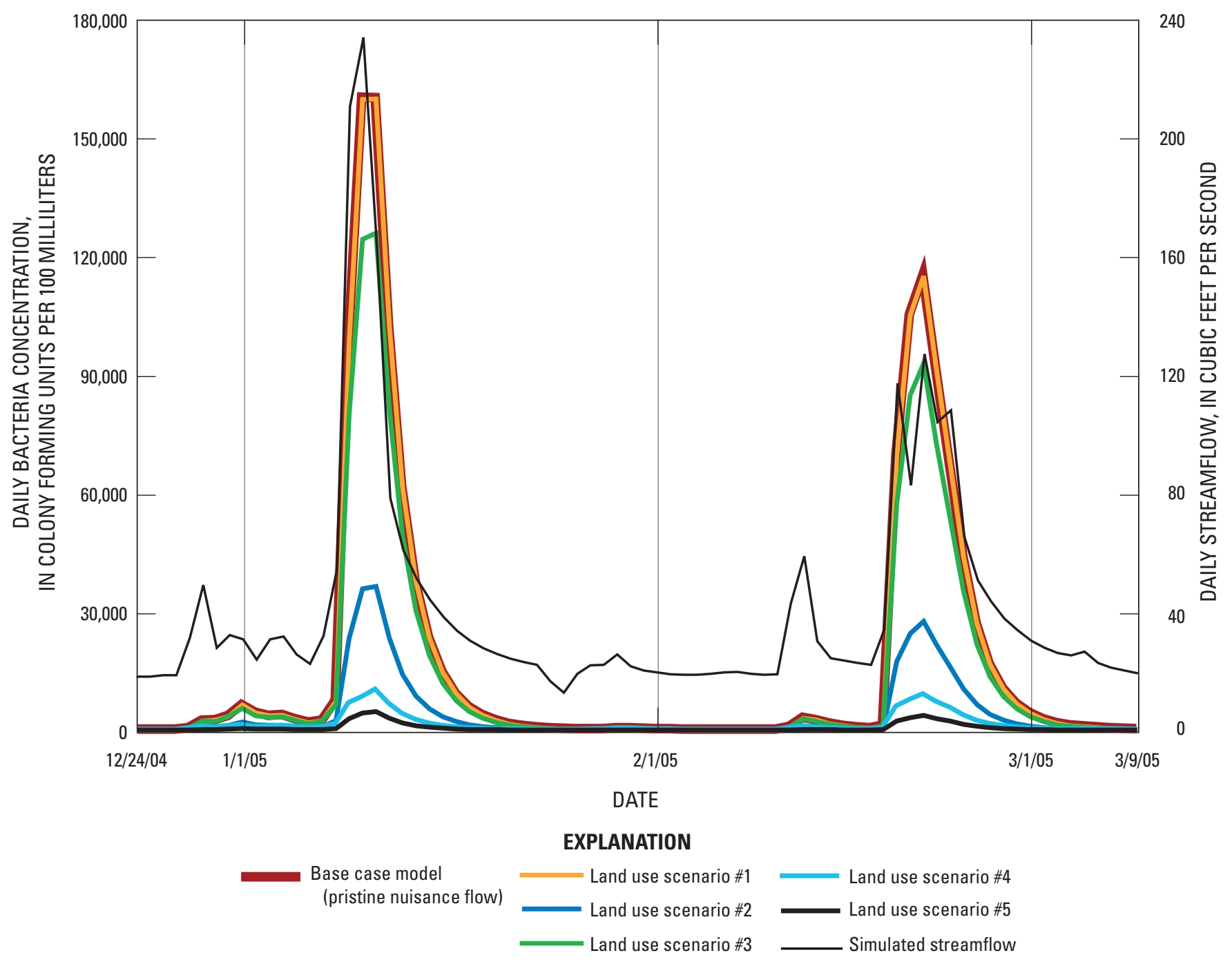

Figure 29. Simulated daily bacteria concentrations sampled during storms in water-year 2005 for 6 land-use scenarios at $A$, Prado Park Lake outflow, $B$, Chino Creek outflow, and C, Mill Creek outflow in the Chino Basin, California.

The concentration duration curves for the 1988-2005 simulated hourly bacteria concentrations (indicating the percentage of time bacteria concentrations are exceeded) using the six land-use scenarios is shown for the same three locations (figs. 30A-C). The concentration duration curves also indicated that Prado Park Lake outflow was the most affected by the land-use scenarios 2, 3, 4, and 5 because this subbasin had the greatest percentage of upstream land area affected by these land-use scenarios (fig. 30A). Land-use scenario 0 has little to no affect on Prado Park Lake outflow because nuisance flows were diluted by RP-1 discharge and the long residence time for water in Prado Park Lake maximizes bacteria die-off (the model does not account for possible bacteria re-growth and point source contamination at Prado Park Lake). Land-use scenario 1 also has no affect because there is no barren and vacant land use upstream of Prado Park Lake. Land-use scenario 2 (conversion of intensive livestock to residential land use) had the greatest affect for changes to a single land use (intensive livestock). Land-use scenarios 2 and 4 significantly reduced maximum bacteria concentrations that occur 4 percent of the time or less (about $600 \mathrm{cfu} / 100 \mathrm{~mL}$ for both scenarios relative to 1,500 for the base case). However, only land-use scenario 5 greatly reduced the percentage of time that bacterial concentrations exceeded $200 \mathrm{cfu} / 100 \mathrm{~mL}$ - to about 3 percent of the time compared with about 12 percent for the base case. Results for Chino Creek outflow indicated a much lower affect on bacteria concentrations caused by the land-use scenarios because the mixed agriculture, intensive livestock, and vacant 


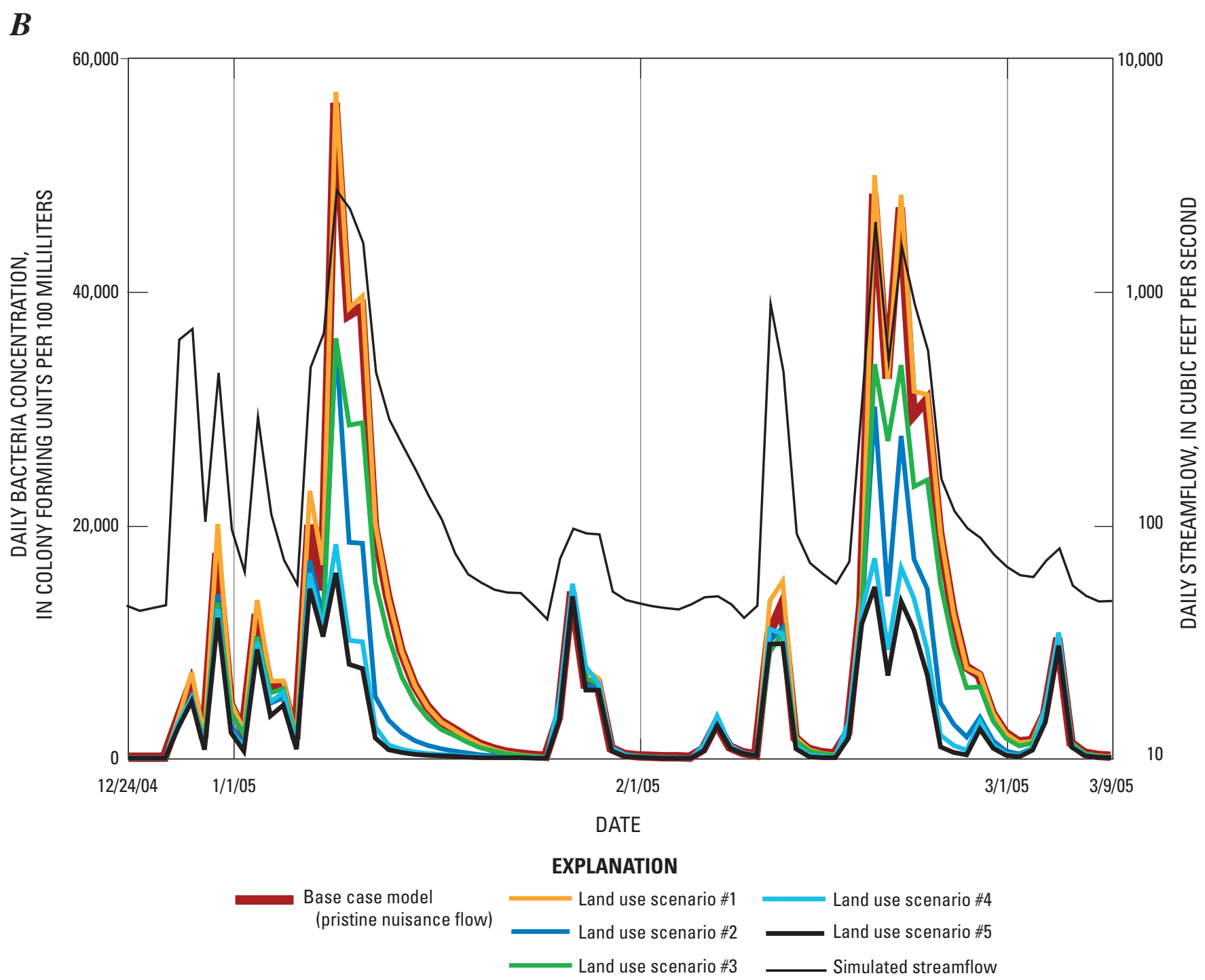

Figure 29. Continued.

or barren land uses do not comprise a large fraction of the total upstream area in the Chino Creek subbasin (fig. 30B). The percentage of time the $200 \mathrm{cfu} / 100 \mathrm{~mL}$ was exceeded is about 10 percent for land-use scenario 5, and about 12 percent for the base case. Results for Mill Creek outflow also indicate a diminished affect from the land-use scenarios relative to the results for Prado Park Lake outflow (fig. 30C). The primary affect of the land-use scenarios at Mill Creek outflow was on the maximum bacteria concentrations that occurred only about 0.1 percent of the time or less.

Location was an important consideration in the evaluation of land-use scenarios because land uses are not distributed uniformly throughout the study area (fig. 6). Upstream locations were likely to include only a subset of land uses in their catchment areas- this is especially true for the mixed agriculture and intensive livestock land uses which are concentrated in the lower part of the Chino Basin. In addition, all locations are likely to be most affected by the nearest upstream land use because of bacteria die-off and dilution during transport.

Land-use scenario 0 (pristine nuisance flow) affected sample site D the most because nuisance flow is the dominantto-sole contribution to low flows at this site. Sites in the lower reaches of Chino Creek (including Prado Park Lake outflow), Cucamonga Creek, and Mill Creek, which are downstream of discharges from wastewater treatment plants, were affected less by land-use scenario 0 . 


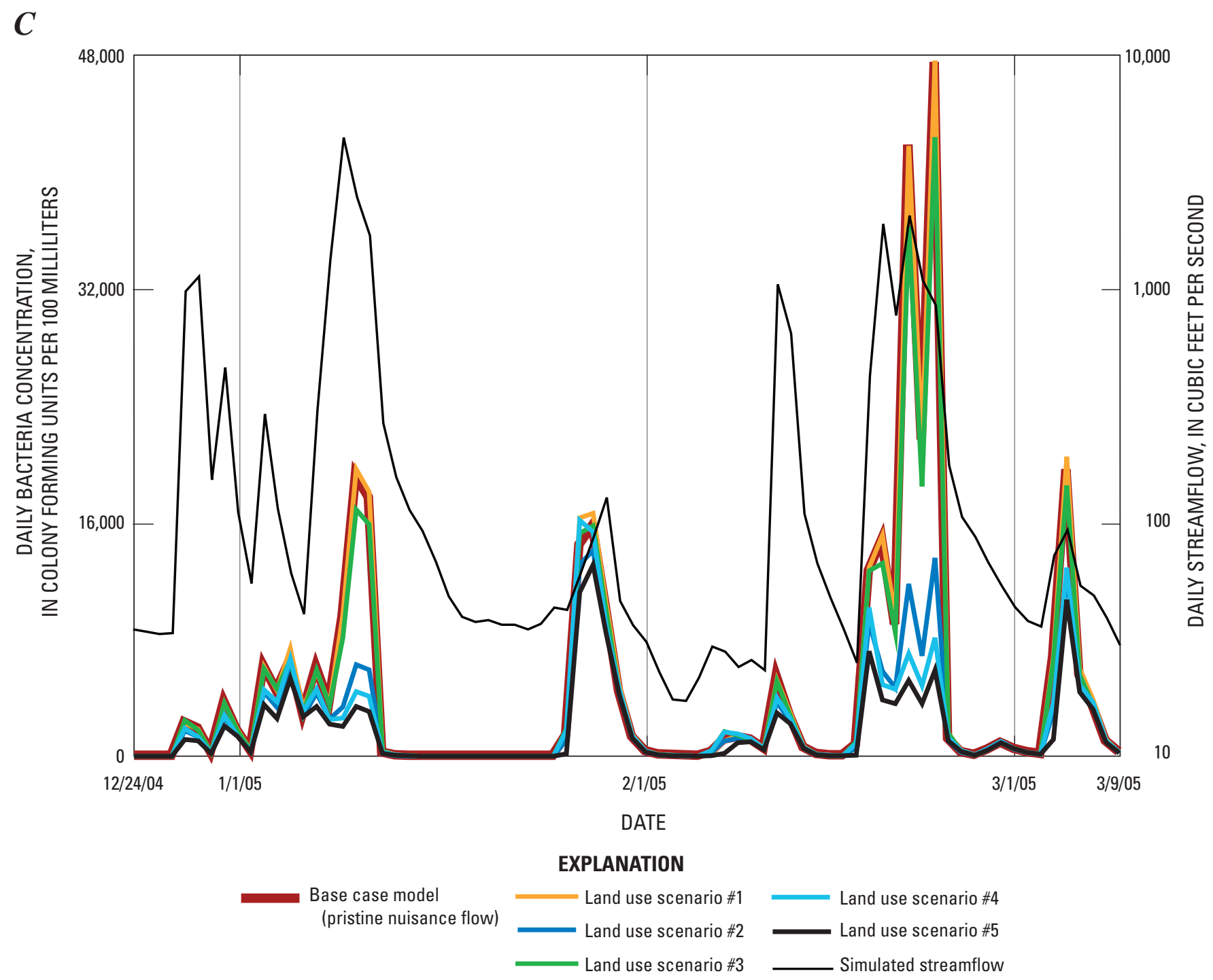

Figure 29. Continued.

Comparing hourly simulation results indicated that (1) the effect of land-use scenario 1 was minor to insignificant at all analyzed locations, (2) land-use scenario 5 had the greatest effect with the greatest reduction in peak concentrations, (3) of the scenarios having a single land use change, land-use scenario 2 (intensive livestock to residential) reduced peak concentrations the most, (4) the effect of land-use scenarios on bacteria concentrations depended mostly on location because land uses are not uniformly distributed throughout the Chino Basin, and (5) for the land-use scenarios considered, relative differences in bacteria concentrations may only be significant for the larger storms that cause runoff (and bacteria washoff) from pervious land areas.

Land-use scenario 5 (barren or vacant, mixed agriculture, and intensive livestock converted to recreation and open space) decreased average and peak bacteria concentrations the most, followed by land-use scenarios 4 (barren or vacant, mixed agriculture, and intensive livestock converted to residential), land-use scenario 2 (intensive livestock converted to residential) and land-use scenario 3 (mixed agriculture converted to residential). This result was expected given that the estimated accumulation and storage of bacteria in intensive livestock and mixed agriculture areas is greater than that in residential areas and much greater than that in recreational and open space areas.

Conversion to residential (all scenarios except 5) increased the percentage of impervious area, which increased the frequency of hourly concentrations exceeding $200 \mathrm{cfu} / 100$ $\mathrm{mL}$. Conversion to recreation and open space (land-use 
$\boldsymbol{A}$
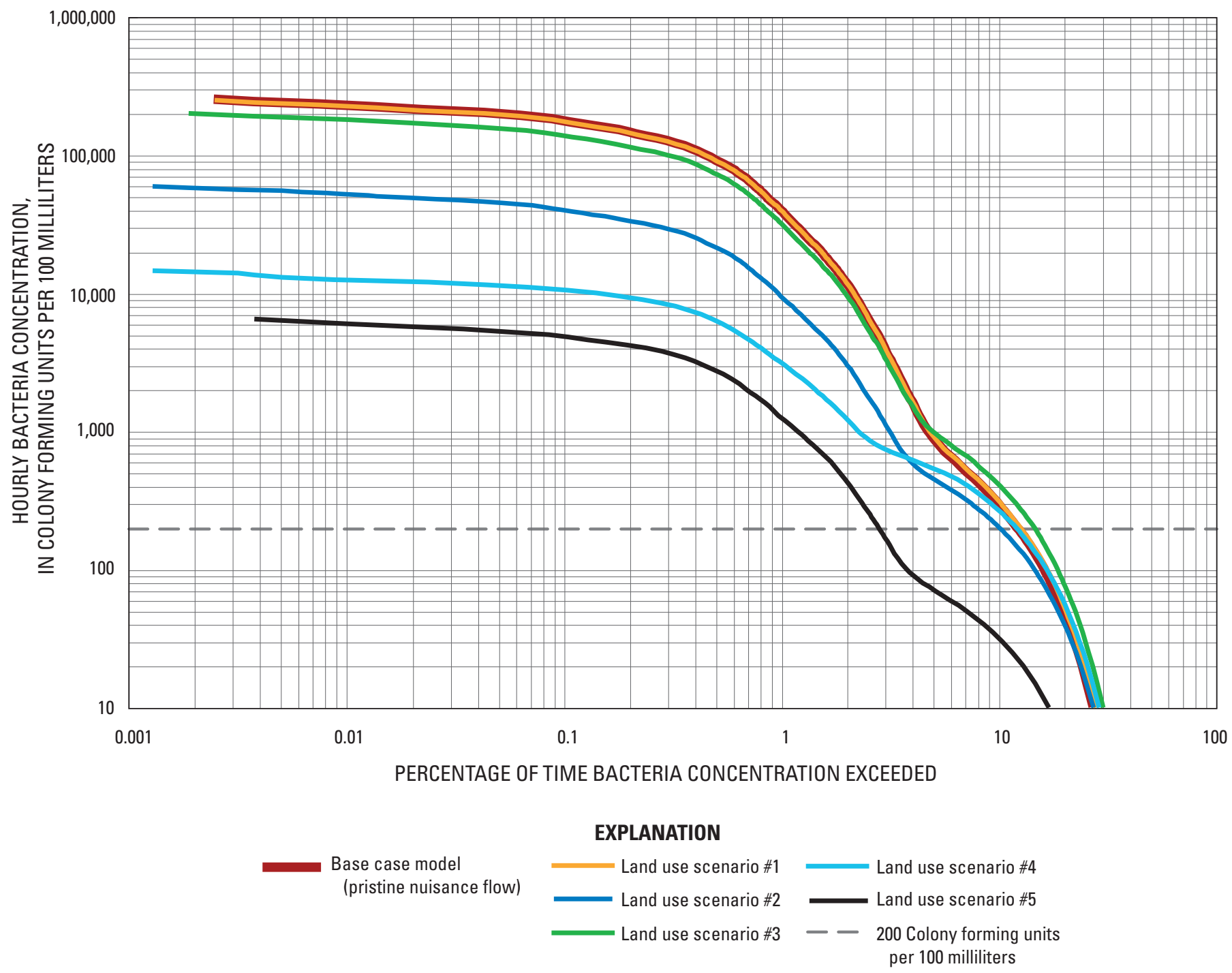

Figure 30. Concentration duration for simulated hourly bacteria concentrations for 6 land-use scenarios during water-year 1988-2005 at $A$, Prado Park Lake outflow, $B$, Chino Creek outflow, and $C$, Mill Creek outflow in the Chino Basin, California.

scenario 5) did not increase impervious area and thus did not increase the frequency of concentrations exceeding $200 \mathrm{cfu} / 100 \mathrm{~mL}$.

For all scenarios where there were significant reductions in bacteria loading, the most significant were for the infrequent peak concentrations in response to the larger storms. The reduction in concentrations below the assumed $200 \mathrm{cfu} / 100 \mathrm{~mL}$ target concentration is much less substantial because this level of bacteria contamination is affected more by the more frequent, smaller storms that cause washoff from impervious areas only. For this reason, land-use scenario 4 caused a slightly higher proportion of hourly bacteria concentrations greater than $10 \mathrm{cfu} / 100 \mathrm{~mL}$ but less than approximately $300 \mathrm{cfu} / 100 \mathrm{~mL}$ at the Prado Park Lake outflow location because of a substantial increase in total upstream impervious area. The increased impervious area resulted in increased bacteria loading for the more frequent, smaller storms.

The land-use scenarios considered in this study generally affected only the lower reaches of the Chino Creek and Mill Creek subbasins, because this is where the mixed agriculture and intensive livestock land uses are located. However, these lower reaches coincide with waterways targeted for multi-use (parks and recreation). In addition, the lower reaches downstream of the mixed agriculture and intensive livestock land uses are the most likely to be affected by extreme bacteria loading in response to large storms, and thus land-use changes are likely to reduce maximum bacteria concentrations the most in this area. 
B
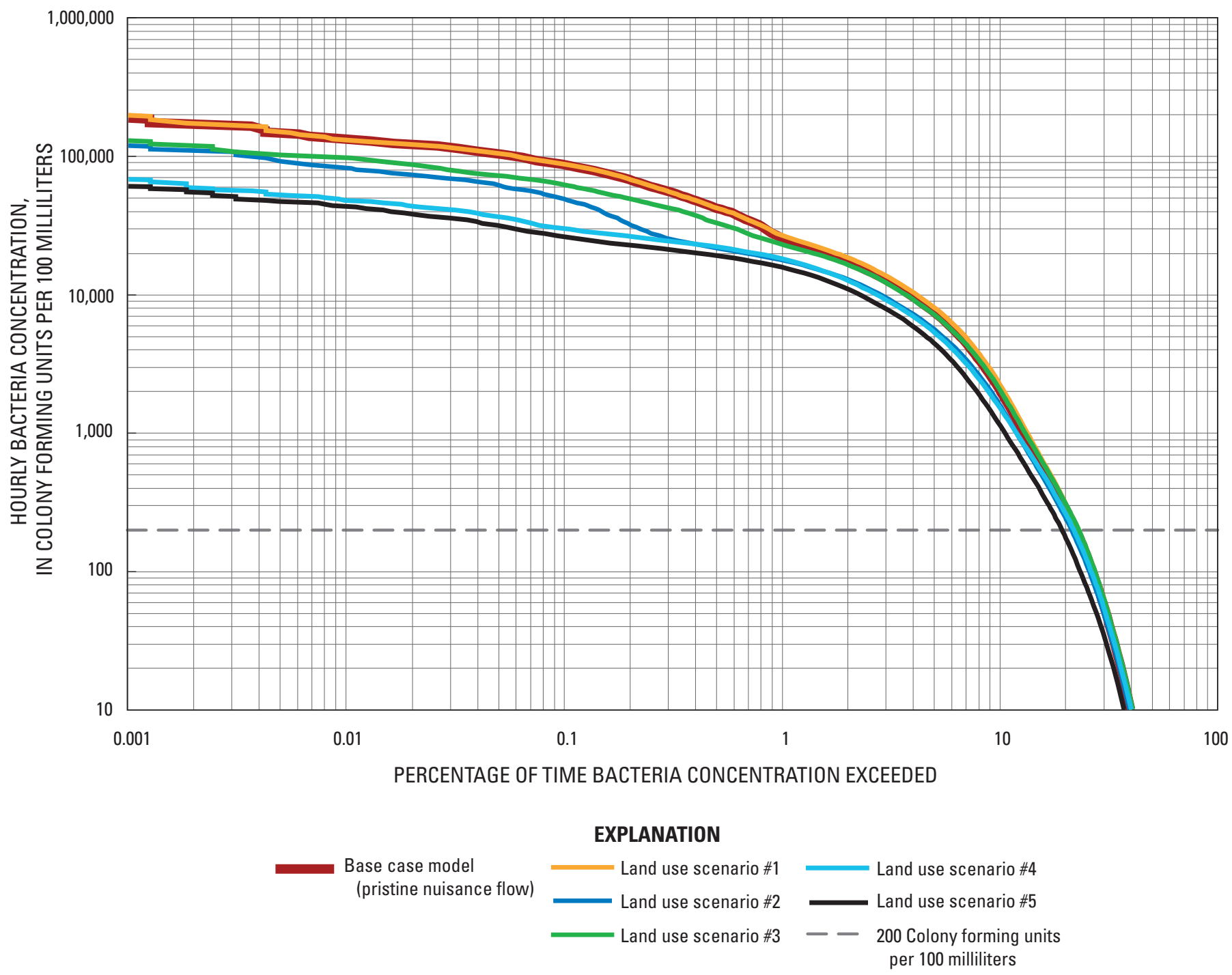

Figure 30. Continued.

\section{Applying Results to Develop TMDLs}

The results of this study indicated that the bacteria loading in the Chino Basin waterways depended more on impervious area bacteria sources and loading rates if the TMDL target concentration of fecal coliform and E. coli was in the range of 100-300 cfu/100 mL (for this study, a target concentration of $200 \mathrm{cfu} / 100 \mathrm{~mL}$ was used for the concentration-duration analysis). Peak concentrations depended more on larger storms and on pervious-area bacteria sources and loading rates. Only the larger storms generated runoff, and thus bacteria washoff, on the pervious areas in the Chino Basin (most precipitation falling on pervious areas enters the soil, and is then lost to evapotranspiration or percolates down below the zone of evapotranspiration and becomes recharge). Land uses that were assigned the highest bacteria-loading (agriculture and feedlots) values affected the time-averaged bacteria loads and the frequency of concentrations exceeding $200 \mathrm{cfu} / 100 \mathrm{~mL}$ less because significant washoff occurred relatively infrequently from the pervious areas (during some years, there is no washoff from pervious areas). For this reason, the changing of areas of modeled land use from agriculture and feedlots to residential did not significantly improve the average water quality of the Chino Basin waterways (and in some cases resulted in a decrease in the time-averaged water quality), although peak bacteria loading was decreased. In contrast, modeling the conversion of vacant, mixed agriculture, and intensive livestock areas to recreation and open space land use 
C
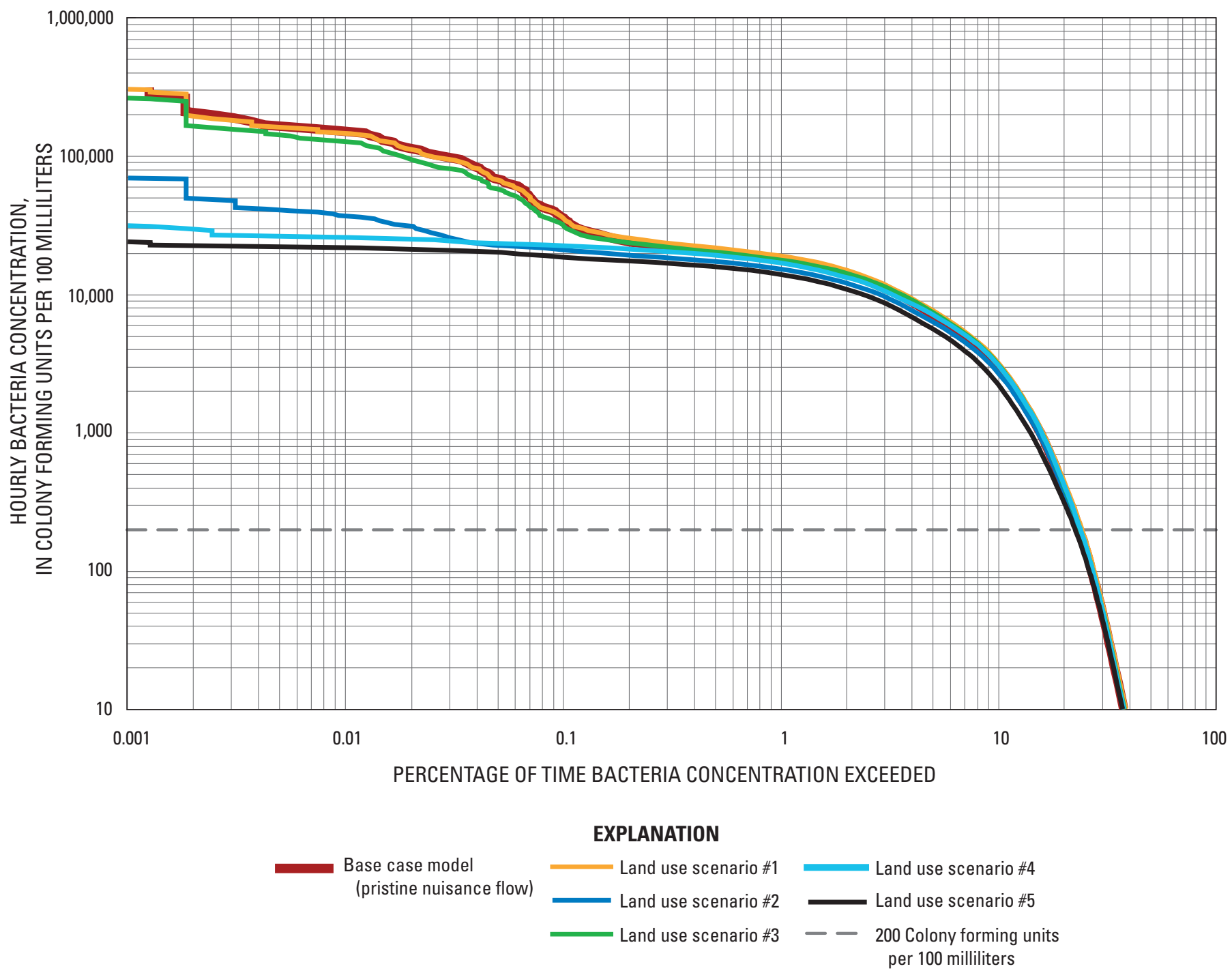

Figure 30. Continued.

areas resulted in a more significant reduction of the peak bacteria concentrations and the frequency of hourly concentrations exceeding $200 \mathrm{cfu} / 100 \mathrm{~mL}$.

Analyses of field data indicated that (1) bacteria loading to nuisance flow (either as point or non-point sources) was significant to the overall bacteria loading, especially for locations where the nuisance flow was the dominant baseflow component, and should be considered as part of the TMDL development. It is hypothesized that the nuisance flow originated primarily as over-watering of irrigated landscapes, which in turn were likely sources of bacteria contamination. The nuisance flow component was included in the model as an estimated constant inflow with uniform bacteria concentration for each RCHRES segment on the basis of the total area of urban land uses contributing to the segment. The contaminated nuisanceflow component was generally supported by the available field data, but was included in the model in a very simplified manner. To evaluate the contribution of nuisance flow relative to storm runoff and other sources of bacteria contamination (groundwater discharge, inflows), a land-use scenario using pristine (uncontaminated) nuisance flow was included in model application and analysis. The results from the evaluation suggested that both storm flow and nuisance flow need to be considered in the TMDL development (storm flow alone does not account for all of the water-quality degradation). Overall, residential land use contributed the greatest total bacteria loading (as indicated by comparing the relative average loading rates for individual land uses). Residential land use accounted for the greatest total area in the Chino Basin, and the field data and subsequent model calibration indicated a moderate to high land-surface accumulation rate. Results from land-use modeling scenarios indicated that an increase in 
residential land use with a corresponding decrease in agriculture, intensive livestock (dairies), or barren or vacant land use did not cause a significant decrease in the frequency that bacteria concentrations in waterways exceeded $200 \mathrm{cfu} / 100 \mathrm{~mL}$. A decrease in mixed agriculture and intensive livestock land use would likely result in a decrease in peak bacteria concentrations during the larger storms, as well as a decrease in total bacteria loading, but this may not change the level of compliance with the TMDL if the frequency or duration of exceeding $200 \mathrm{cfu} / 100 \mathrm{~mL}$ is used as the criterion. Reducing the effective impervious area would likely affect TMDL compliance more favorably.

Calibrating models contains uncertainties. In particular, the small sample size for storm runoff for specific land uses, such as recreation and open space, and a lack of samples for definitive pervious-area runoff from the urban and agricultural land uses (samples from large storms), increased uncertainties in the model. Results from the land-use scenario analysis suggest that commercial and services land use has the highest estimated loading rates (this is consistent with the relative loading rates of the regional parameters). The loading rates may be correlated to size and number of irrigated landscapes and the degree of over-watering, which would also explain the high degree of contamination in the nuisance flows. Domestic animals (pets) and wildlife (birds, rats) likely rely on the overwatering as a source of drinking water. Industrial land-use areas have a lower loading rate because of fewer over-watered landscapes (there are fewer animals because there is less available water).

The calibrated loading rates for fecal coliforms were higher than the regional fecal coliform loading rates developed by the Southern California Coastal Water Research Project Authority (SCCWRP) for the Los Angeles region for most (but not all) land uses. The calibrated loading rates for urban and agricultural land uses were mostly higher than the SCCWRP rates, while loading rates for natural areas were mostly lower. This may be related to climate: the drier climate of the Chino Basin study area (hotter conditions, lower humidity compared with that of the coastal watersheds) encourages less wildlife in the natural environments and increased irrigation (and thus overwatering) in the urban environment (which attracts more animals to the irrigated landscapes). Thus, a reduction of overwatering may lead to a reduction in bacteria loading for both nuisance flows (nuisance flows would decrease if overwatering decreased) and storm flows (bird and rodent populations would decrease). Using more retention basins to capture contaminated runoff and allow bacteria and pathogens to die off may also help improve downstream water quality.

Results of the modeling indicate that conversion of the mixed agriculture and intensive livestock land uses to the recreation and open-space land use would significantly improve water quality for the Prado Basin. Water quality in the lower sections of Chino Creek and Mill Creek would also improve, but the effect would be smaller because only a small fraction of the total area supplying runoff to these main channels would be affected by the land use change. The recreation and open-space land use was calibrated to have bacteria loading rates lower than that for residential and commercial and services land uses and thus converting to this land use would improve water quality substantially more than converting to other land uses. Given the greater likelihood that the mixed agriculture and intensive livestock land uses will eventually be converted to residential land use, peak and total bacteria loading will still decrease substantially. However, the frequency at which bacteria concentrations exceed a given criterion level (for example, a limit of $200 \mathrm{cfu} / 100 \mathrm{~mL}$ for fecal coliform) may not change significantly. The results from this study suggest that if there are no changes in the existing conditions affecting the quality of urban runoff from impervious areas, water quality may even diminish in terms of the frequency of contamination, regardless of land-use changes, as the percentage of impervious area increases.

\section{Summary and Conclusions}

Pathogen indicator bacteria concentrations were measured during three storms in water-year 2004 at 9 locations in the Chino Basin to help evaluate water quality and to develop and calibrate a Hydrological Simulation Program-FORTRAN (HSPF) pathogen-indicator bacteria transport model for the Chino Basin. The data and transport model are being used for the Chino Basin study area as part of ongoing work to establish a pathogen-indicator bacteria Total Maximum Daily Load (TMDL) for a part of the Santa Ana River watershed that primarily includes the Chino Basin tributary.

The pathogen-indicator bacteria samples collected during the 3 storms in water-year 2004 included total coliform, fecal coliform, E. coli, and enteroccoci. The data set was supplemented by indicator bacteria samples available from previous and ongoing water-quality studies in the Chino Basin. The bacteria data indicated elevated bacteria concentrations high above limits considered as being potentially harmful to human health, downstream of the highly urbanized central part of the Chino Basin and downstream of the mixed agriculture and intensive livestock areas in the southern part of the basin.

The HSPF transport model area incorporated a relatively detailed representation of the urban area hydrography using 10- and 30-meter digital elevation models (DEM), available storm-drain maps, hydrography maps, detailed and fairly recent (2000) land-use maps, high-resolution orthophotos, and an available map of estimated 2001 imperviousness. The drainage system was defined using 229 reach and reservoir model segments that were grouped into 46 land area segments having consistent land-surface and climate properties. The land-use map was used to define 12 pervious-area land types and 9 impervious area land types that were superimposed onto the 46 land area segments, generating a total of 966 hydrologic response units. Parameters controlling streamflow and bacteria transport processes were defined for all hydrologic response 
units, and these were distributed by contributing area over the 229 reach and reservoir segments.

National Land Cover Dataset (NLCD) impervious-area maps were used to better quantify differences between pervious and impervious land areas within the 12 land types that were identified on the basis of generalized land uses and vegetation groups. The 12 land types were (1) shrubs and grasses; (2) forest; (3) barren and vacant; (4) mixed urban; (5) recreation and open space; (6) commercial and services; (7) utilities and transportation; (8) medium to high density residential; (9) industrial; (10) mixed agriculture; (11) wetlands and water bodies; and (12) intensive livestock (dairies). Shrubs and grasses, forest, and wetlands and water did not have significant impervious areas and thus were defined only as pervious-area land types. Initial impervious-area percentages (as a percentage of total land-use area) were refined to improve model calibration. Identifying the relative pervious and impervious areas for the various land uses and land types for the Chino Basin was an important part of model development because storm runoff and streamflow were very sensitive to the impervious areas affecting the drainage system.

Developing spatially distributed hourly climate inputs using available data from a regionally distributed network of monitoring sites helped in calibrating the Chino Basin model to hydrographs that reflected complex hydrological processes. Areally-distributed recharge over pervious land units did not account for all recharge because of significant artificiallyinduced recharge throughout the basin. Adding representation of in-stream recharge processes (retention basins) helped improve model calibration.

Evaluation of simulated hourly fecal coliform bacteria concentrations in the Chino Basin study area indicated important differences in contributions to bacteria loading between impervious and pervious source areas. Impervious areas tended to cause bacteria loading to be much more frequent, particularly bacteria concentrations less than approximately $1,000 \mathrm{cfu} / 100 \mathrm{~mL}$, because precipitation amounts from and intensities of most storms are not sufficient to generate significant runoff and bacteria washoff from pervious areas. Runoff usually comes from pervious areas when the soils become saturated, and in the central and southern parts of the Chino Basin, this only occurs in response to the larger storms during wetter than normal years. In contrast to pervious areas, runoff and subsequent bacteria washoff comes from impervious areas during all storms with precipitation exceeding the surface retention storage term, which was estimated to range from 0.08 to 0.15 in. for the Chino Basin study area. However, pervious-area washoff often results in more than 1 order of magnitude greater bacteria concentrations in downstream reaches, especially in locations where the upstream areas are used mostly for mixed agriculture and intensive livestock, uses which were calibrated as generating high bacteria accumulation rates per unit land area.

Analyses of simulated and measured bacteria concentrations at many different sampling sites in the Chino Basin indicated that storm flows (runoff in response to precipitation) alone cannot account for all measured elevated bacteria concentrations. The field data and simulation results suggest that nuisance flows (flows originating as very small inflows from urbanized areas) likely contribute significantly to bacteria loading throughout the Chino Basin. The uncertainties encountered in model calibration with regard to estimates of nuisance flows indicated that they are an important data need and should be considered when interpreting the processes affecting water quality.

The correlation between storm flow and bacteria concentration was poor for most locations, and depended on location (upstream or downstream) along the drainage network and the ratio of pervious to impervious area. Small catchments with a high percentage of impervious area were characterized by rapid washoff of bacteria, even for relatively small runoff events. For most storms, the bacteria concentration peaked during the early (rising limb) stages, represented by the storm hydrograph, as increasing runoff diluted the initial bacteria loads. As runoff decreased, bacteria concentrations often increased because die-off is slow relative to the decrease in flow indicated by the falling limb of the hydrograph, and owing to delayed inflows of more contaminated runoff from upstream areas. For very low flows, bacteria concentrations could become very high because the evaporation rate exceeded the die-off rate. Small catchments with a high percentage of pervious area (agriculture, feedlot, open space land uses) were characterized by peak bacteria loads better correlated to the magnitude of streamflow because washoff from the pervious areas tended to occur only during the larger storms. During drier than normal periods, only the impervious areas contributed to bacteria loading and subsequent pathogenic degradation of downstream water quality.

Using different climate and land-use scenarios in the model helped improve understanding of processes affecting bacteria concentrations (and thus pathogen contamination) in the Chino Basin. Changing the average air temperature substantially affected simulated streamflow in the northern part of the Chino Basin because of the effect on snow pack formation and melting and the bacteria loading from mountain-front canyons (San Antonio Canyon, Cucamonga Canyon, and Deer Creek Canyon). In general, higher temperatures caused an increase in simulated bacteria concentrations. However, increased bacteria concentrations in streamflow discharging from the mountain-front canyons had very little effect on the downstream sections of the drainage system in the model simulations because this streamflow is a minor fraction of the total runoff generated in the Chino Basin.

Increased precipitation resulted in simulations having improved water quality for pristine areas (shrubs and grasslands, forests) in the northern, mountainous part of the basin, owing to dilution. In contrast, increased precipitation caused a simulated decrease in water quality for urban areas and downstream parts of the Chino Basin watershed because runoff from pervious areas for land uses with relatively high loading rates increased. A decrease in precipitation could also diminish water quality at locations in the drainage that are 
strongly affected by nuisance flows, because of less dilution and higher constituent concentrations during low flow conditions. Locations downstream of wastewater inflows were usually less sensitive to nuisance flow contamination when the wastewater inflows were pristine (this was generally supported by the available data). Locations downstream of surface-water storage facilities also usually had lower simulated bacteria concentrations during low flows because bacteria die-off and dilution decreased concentrations in the stored water. However, the simplified advective transport model used in this study did not account for possible bacteria regrowth or resuspension as particulate matter. These processes might be better represented using a sediment transport model.

The primary conclusions regarding the relation of pathogen indicator bacteria to land use in the Chino Basin is that the urban land uses generate a higher frequency (owing to impervious areas), yet lower magnitude, bacteria load, whereas the intensive livestock and mixed agriculture land uses generate higher peak loads but less often. The simulated peak bacteria loads occurred infrequently because only the largest storms generated substantial runoff from the pervious areas.

Results from this study indicated that if management options or Total Maximum Daily Load (TMDL, a pollution control plan) requirements are to be based on how often certain thresholds (such as $200 \mathrm{cfu} / 100 \mathrm{~mL}$ ) are exceeded, then it is probably more important to control bacteria buildup and washoff from impervious areas than from pervious areas. A shift from mixed agriculture and intensive livestock land uses to residential land use upstream of an impaired reach may not have the desired effect in terms of meeting a TMDL requirement, because the frequency that threshold concentrations are exceeded may not change very much. On the other hand, if criteria for management options or TMDL requirements are to be based on peak loads, then reducing buildup and washoff from the pervious areas of urban and agricultural land uses (including intensive livestock) would be more important. A change in land use from mixed agriculture and intensive livestock to residential may meet management or TMDL requirements if based on peak loads or total loads.

A change from mixed agriculture and intensive livestock (dairies/feedlots) to residential land use would most likely affect the Prado Basin, because a high percentage of the area upstream of this drainage is used for mixed agriculture and intensive livestock. Model results indicated that during wet years such as 2005, the effect of runoff from mixed agriculture and intensive livestock to Prado Park Lake is extreme. The effect in other areas depends on location, as most of the basin is upstream of the intensive livestock land use, but the lower part of the basin is influenced by dilution from the wastewater effluent. Streamflow upstream of the treatment plants is not diluted and the bacteria load coming directly from the urban areas, from both nuisance flow and storm runoff, appears to be significant.
The accuracy of model simulations of future climate and land-use scenarios cannot be quantified without additional field data consisting of both land-use-targeted sampling of small catchments in upstream areas and integrated response samples from the main channels, preferably from streamgage locations. The results obtained in this study suggest an important distinction between impervious and pervious land area processes contributing to the total bacteria load. However, the most important pervious areas with potential bacteria loading are generally located in the lower part of the Chino Basin, downstream of the stream gages used to calibrate the stream flow component of the transport model. Therefore, since data could not be collected in one location for both streamflow and bacteria loading in pervious areas, the model calibration did not fully represent the pervious land-use areas (mixed agriculture and intensive livestock) and could not be sufficiently calibrated. Location of additional stream gages downstream of the mixed agriculture and intensive livestock land uses would greatly improve model accuracy in representing the pervious area contribution to bacteria loading.

Low soil infiltration rates assigned for the lower part of the Chino Basin were estimated on the basis of the high percentage of clays indicated in available STATSGO and SSURGO data. Simulated runoff and subsequent bacteria washoff for these areas is likely to be sensitive to these low infiltration rates, and as a result, indicates that soil properties should be more accurately defined. Runoff generation was also sensitive to precipitation intensity, which can vary greatly for the hourly time step used in this model. The hourly precipitation inputs are mostly based on the available 1-hour precipitation data but in some cases are based on 1-hour totals of higher resolution (15 or 5 minute) data. The higher resolution data more accurately represent maximum precipitation intensities occurring during shorter (less than 1 hour) time intervals, but the number of stations with higher resolution data is much less than stations with hourly data.

Nuisance flow was observed to be an important factor affecting overall water quality for the study area, especially in terms of the frequency or duration of impaired water quality. However, nuisance flow was also considered to be the least accurately represented component of the HSPF flow and transport model. In order to better characterize the nuisanceflow component, more streamflow and water-quality data are needed for channels affected only by urban runoff and nuisance flow (such as the drainage upstream of gage 11073493). To improve model accuracy the bacteria sampling must include more data collected during dry periods when only nuisance flow is occurring in the channel. In addition, sources of nuisance flow contamination would be better understood by monitoring discharges from various storm drains and land uses. 


\section{Acknowledgments}

This study was supported by the Santa Ana Watershed Project Authority. Supporting and interested stakeholders included San Bernardino County, Los Angeles County, Orange County, Riverside County, Inland Empire Utilities Agency, Wildermuth Environmental Inc., U.S. Army Corps of Engineers, and the Regional Water Quality Control Board.

Funding for this project has been provided in part through an agreement with the State Water Resources Control Board (SWRCB) pursuant to the Costa-Machado Water Act of 2000 (Proposition 13) and any amendments thereto for the implementation of California's Nonpoint Source Pollution Control Program. The contents of this document do not necessarily reflect the views and policies of the SWRCB, nor does mention of trade names or commercial products constitute endorsement or recommendation for use.

\section{References Cited}

Ackerman, Drew, and Weisberg, S.B., 2003, Relationship between rainfall and beach bacterial concentrations on Santa Monica Bay beaches: Journal of Water and Health, v. 1, no. 2, p. 85-89.

Belitz, Kenneth, Hamlin, S.N., Burton, C.A., Kent, Robert, Fay, R.G., and Johnson, Tyler, 2004, Water quality in the Santa Ana basin, California, 1999-2001: U.S. Geological Survey Circular 1238, 47 p.

Bicknell, B.R., Imhoff, J.C., Kittle, J.L., Jr., Donigian, A.S., Jr., and Johanson, R.C., 1997, Hydrological Simulation Program-FORTRAN, User's manual for Version 11: U.S. Environmental Protection Agency, National Exposure Research Laboratory, Athens, Ga., EPA/600/R-97/080, 775 p.

California Irrigation Management information System (CIMIS), 2005, Meteorological data: California Department of Water Resources and University of California at Davis. Available at http://www.cimis.water.ca.gov/

Daly, C., Gibson, W.P., Doggett, M., Smith, J., and Taylor, G., 2004, Up-to-date monthly climate maps for the conterminous United States: Proceedings of the 14th Conference on Applied Climatology, $84^{\text {th }}$ American Meteorological Society Annual Meeting, Seattle, Wash., January 13-16, 2004, Paper P5.1, CD-ROM.

Donigian, A.S., Bicknell, B.R., and Imhoff, J.C., 1995, Hydrological Simulation Program-FORTRAN (HSPF), in Singh, V.P., ed., Computer models of watershed hydrology, chap. 12. p. 395-442.
Guay, J.R., 2002, Rainfall-runoff characteristics and effects of increased urban density on streamflow and infiltration in the eastern part of San Jacinto River Basin, Riverside County, California: U.S. Geological Survey Water-Resources Investigations Report 02-4090, 60 p.

Izbicki, J.A., Pimental, M.I., Leddy, M., and Bergamaschi, Brian, 2004, Microbial and dissolved organic carbon characterization of stormflow in the Santa Ana River at Imperial Highway, Southern California, 1999-2002: U.S. Geological Survey Scientific investigations Report 2004-5116, 80 p.

Martin, J.L, and McCutcheon, S.C., 1999, Hydrodynamics and transport for water quality modeling: Boca Raton, Fla., Lewis Publishers, 794 p.

Moyer, D.L., and Hyer, K.E., 2003, Use of the Hydrological Simulation Program-FORTRAN and bacterial source tracking for development of the fecal coliform Total Maximum Daily Load (TMDL) for Accotink Creek, Augusta County, Virginia: U.S. Geological Survey, Water-Resources Investigations Report 03-4160, 67 p.

Rice, W.B., 2005, Staff report on bacterial indicator total maximum daily loadings in the middle Santa Ana River watershed: Report to California Regional Water Quality Control Board, Santa Ana Region, February 3, 2005, 144 p.

Soil Survey Staff, 2007, Soil Survey Geographic (SSURGO) Database: Natural Resources Conservation Service, U.S. Department of Agriculture, accessed 3/31/04 at http://soils. usda.gov/survey/geography/ssurgo/

Stein, E.D., Ackerman, Drew, and Schiff, Kenneth, 2003, Watershed-based sources of contaminants to San Pedro Bay and Marina del Rey-Patterns and trends, Southern California Coastal Water Research Project: Report prepared for the Los Angeles Contaminated Sediments Task Force.

Tetra Tech, Inc., 2003, Lake Elsinore and Canyon Lake nutrient source assessment: Submitted to the Santa Ana Watershed Project Authority, 11615 Sterling Ave., Riverside, California, $149 \mathrm{p}$.

U.S. Army Corps of Engineers, 1991, Water control manual, San Antonio Dam, Los Angeles County and San Bernardino County, San Antonio Creek, California: Los Angeles District, $128 \mathrm{p}$.

U.S. Army Corps of Engineers, 2005, Daily outflow data for San Antonio Dam. Available at http://www.spl.usace.army. mil/resreg/

U.S. Department of Agriculture, 1994, State Soil Geographic (STATSGO) Data Base—Data use information: Natural Resource Conservation Service, Misc. Pub. no. 1492, (http://soils.usda.gov/survey/geography/statsgo/). 
U.S. Environmental Protection Agency, 1985, Rates, constants, and kinetics formulations in surface water quality modeling (2d ed.): U.S. Environmental Protection Agency, EPA 600/3-85/040.

U.S. Environmental Protection Agency, 1986, Ambient water quality criteria for bacteria: U.S. Environmental Protection Agency, EPA 440/5-84-002.

U.S. Environmental Protection Agency, 2000, Basins case study 1: Cottonwood Creek Watershed, Idaho County, Idaho: U.S. Environmental Protection Agency, EPA 823-R00-024, 12 p.

U.S. Geological Survey, 2001, The national map seamless server database. Available at http://seamless.usgs.gov/website/seamless
Wildermuth Environmental, Inc., 2003, Chino Basin optimum basin management program—Chino Basin dry-year yield program: Prepared for Chino Basin Watermaster, inland Empire Utilities Agency, Chino, Calif., 141 p.

Yagow, G., Dillaha, T., Mostaghimi, S., Brannan, K., Heatwole, C., and Wolfe, M.L., 2001, TMDL modeling of fecal coliform bacteria with HSPF: Proceedings of the American Society of Agricultural Engineering International Meeting, Sacramento, Calif., Paper No. 01-2066, 20 p.

Zarriello, P. J., 1999, A precipitation-runoff model for part of the Ninemile Creek watershed near Camillus, Onondaga County, New York: U.S. Geological Survey WaterResources Investigations Report 98-4201, 60 p. 


\section{Appendix 1. Water-Quality Data Collected by the USGS in Water-Year 2004 in the Chino Basin}




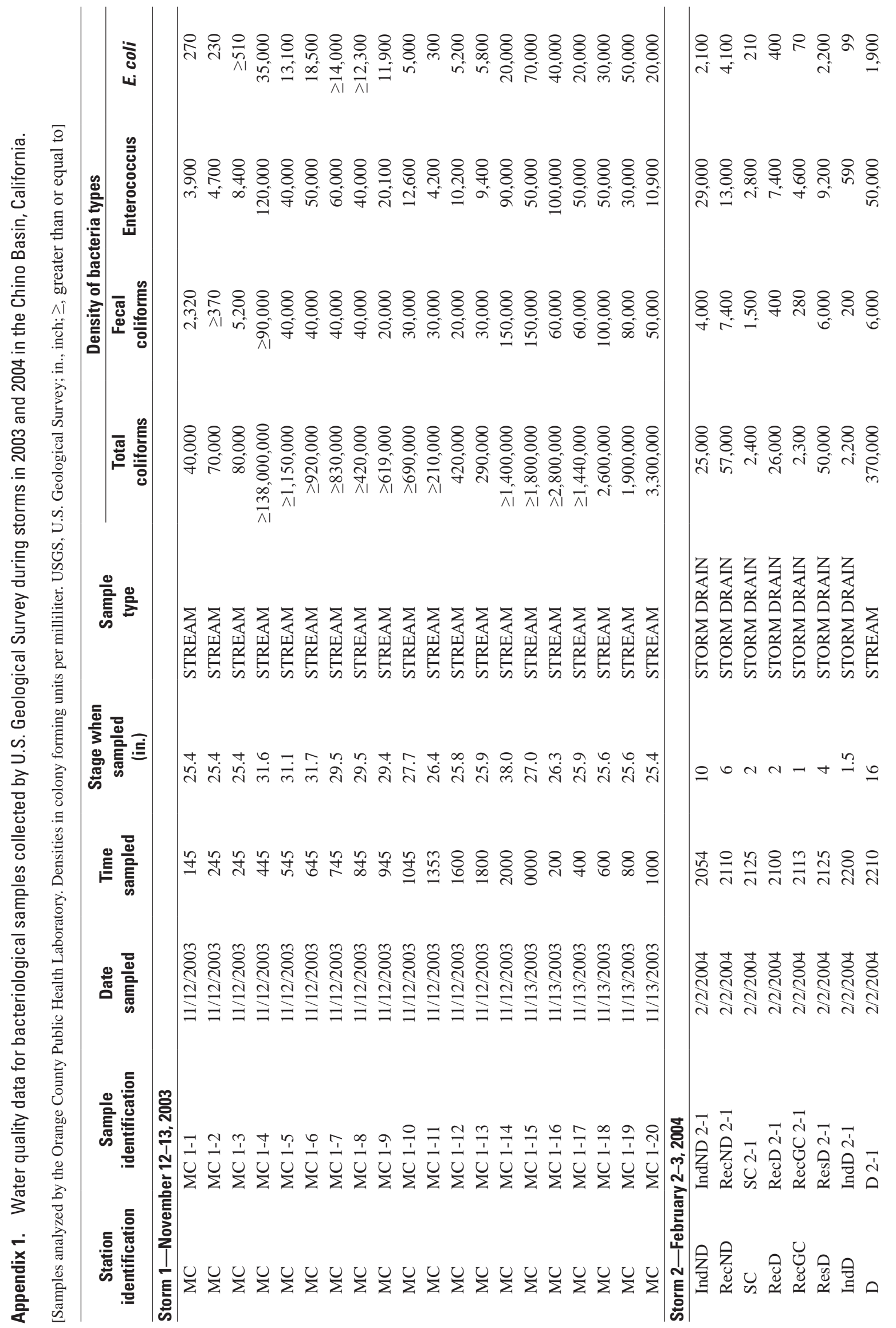




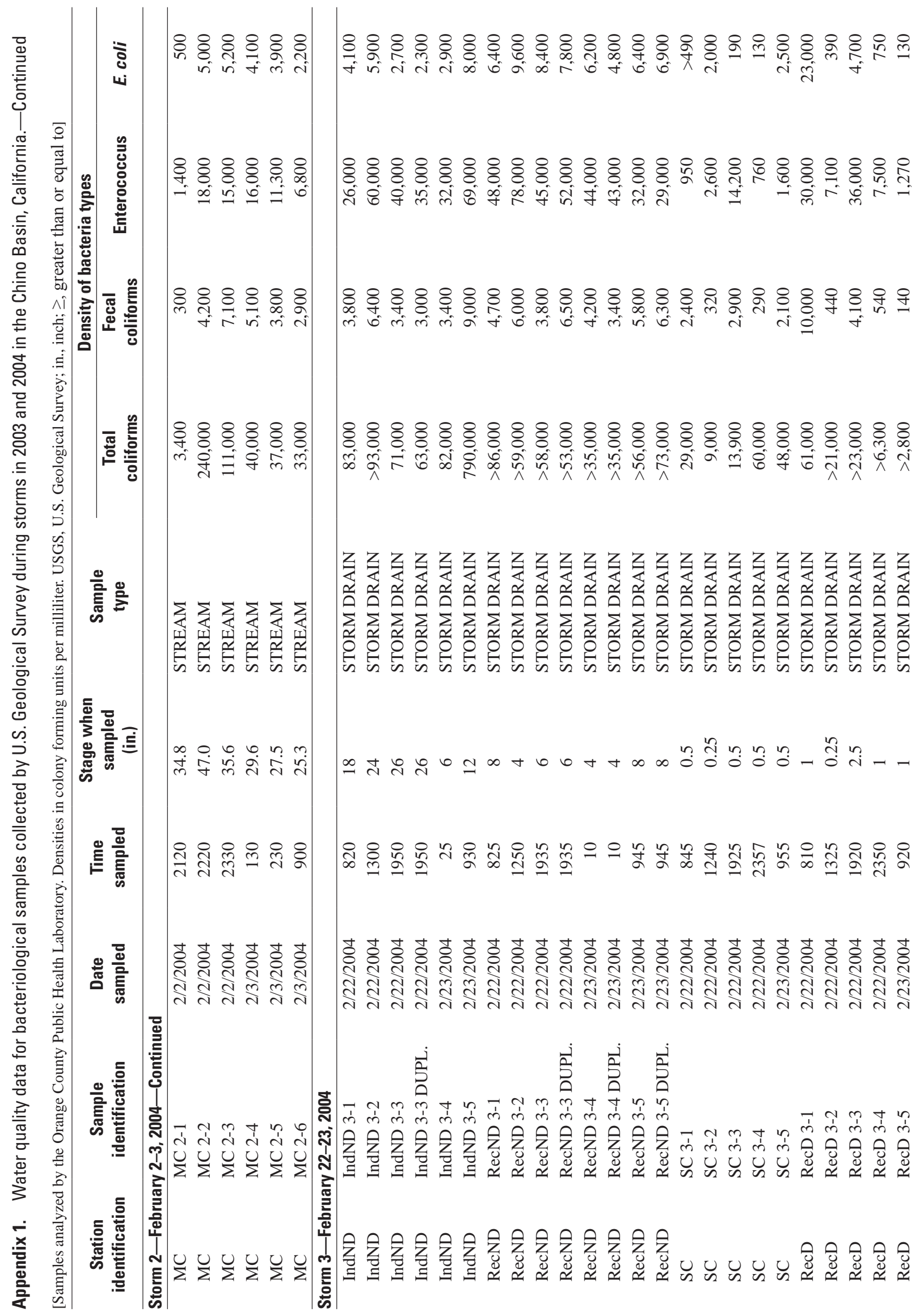




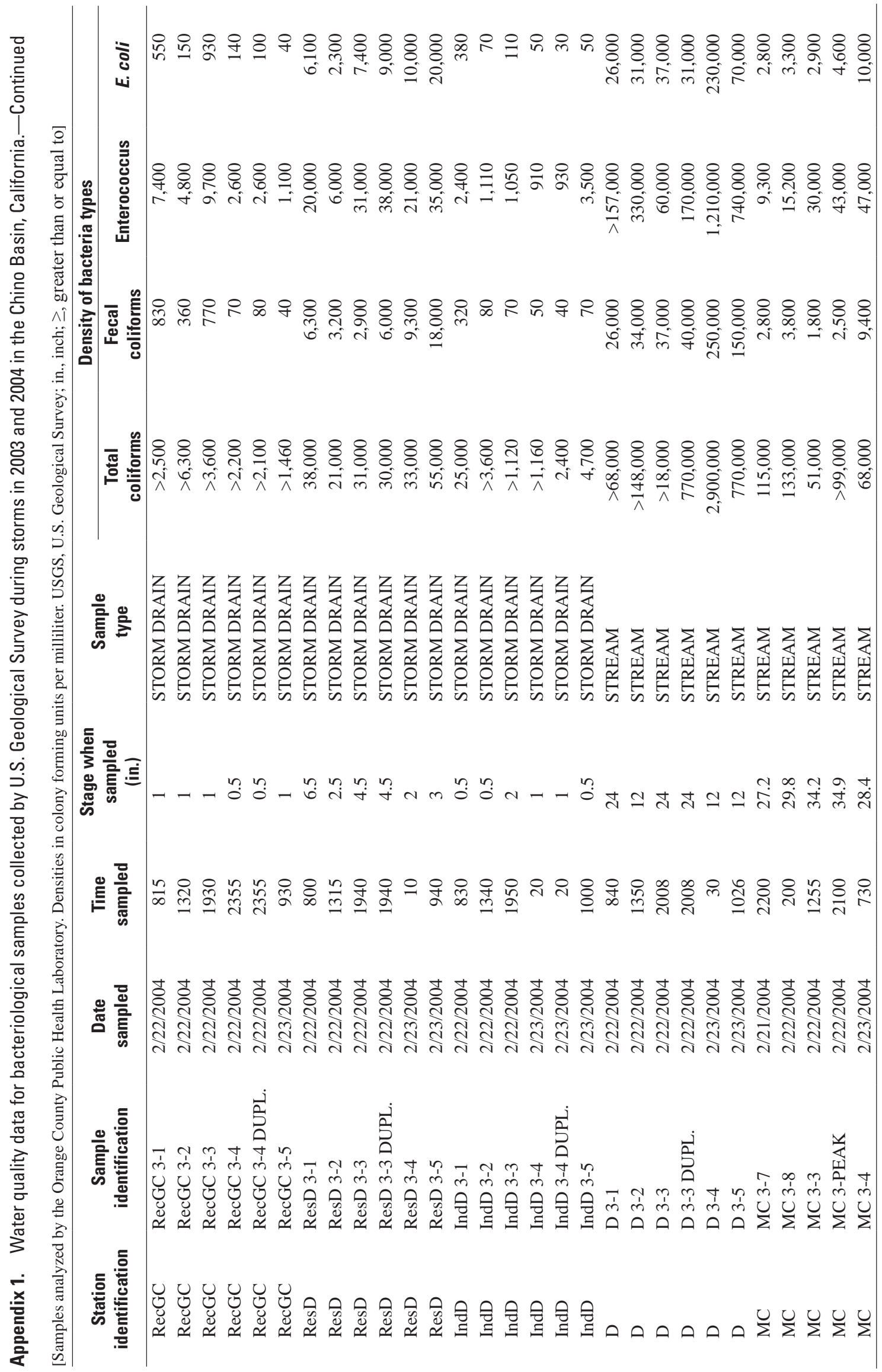




\section{$\frac{\mathbb{2}}{\mathscr{3}}$}

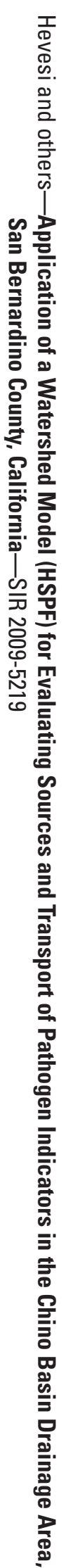

83 Printed on recycled paper 